

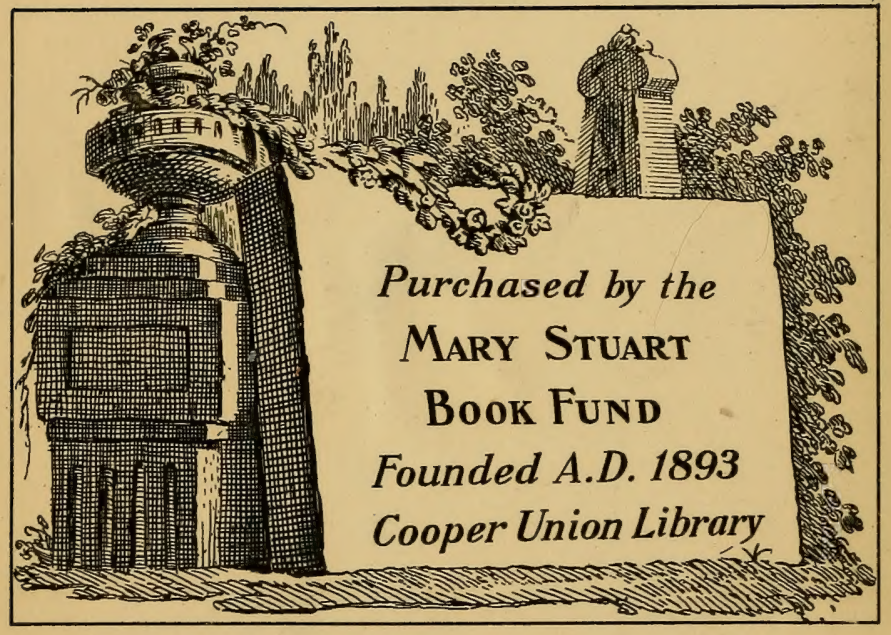




THE HERITAGE OF DRESS

$c, U$. 




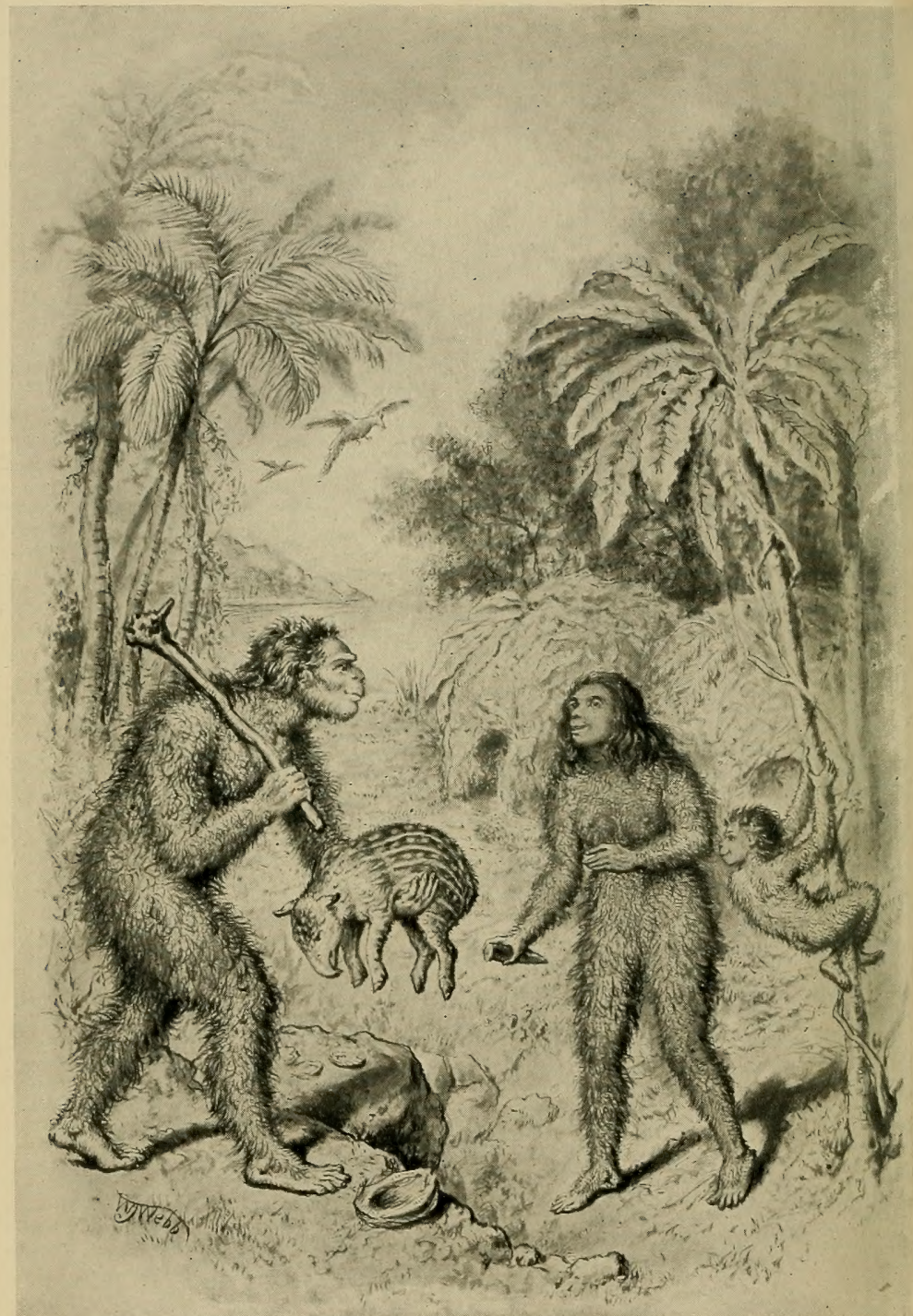

Very EARLy man in Java. (See page 5.) 


\section{THE HERITAGE OF DRESS}

BEING NOTES ON THE HISTORY AND EVOLUTION OF CLOTHES

BY

WILFRED MARK WEBB

FELLOW OF THE LINNEAN SOCIETY OF LONDON GENERAL SECRETARY OF THE SELBORNE SOCIETY EDITOR OF "KNOWLEDGE"

WITH TWELVE PLATES

AND ONE HUNDRED AND SIXTY-NINE FIGURES IN THE TEXT

NEW AND REVISED EDITION

\section{LONDON}

\section{The Times jbook Club}


$G T$

$$
\begin{aligned}
& 510 \\
& W 4 \\
& 1912 \times 346 \\
& \text { CMM w368k }
\end{aligned}
$$


TO HIS WIFE

HILDA E. WEBB

AS A SMALL

TOKEN OF AFFECTION

THIS BOOK IS

DEDICATED BY

THE WRITER

201087 



\section{PREFACE TO THE SECOND EDITION}

THE HERITAGE OF DRESS having been out of print for some time, the writer has taken the opportunity afforded him of issuing a second edition, and at the same time of making certain alterations in and additions to the text. Through the efforts of the present publishers the book has been produced in a compacter and handier form without curtailing it in any way, while the price has been halved; a fact which should tend to carry the volume into those "quiet places" where Ruskin tells us science only lives "with odd people, mostly poor."

\section{WILFRED MARK WEBB.}

ODSTOCK, HANWELL,

April, rgr2. 



\section{PREFACE TO THE FIRST EDITION}

$T^{\mathrm{T}}$ would be difficult to find a subject of more universal 1 interest than that of dress, and hosts of books have been written which deal with the attire that has been adopted at different times and by various nations or social classes. The ornamental and artistic sides of the question have also received much consideration, but the volumes that have appeared serve chiefly as works of reference. The present book aims at being of more immediate interest and usefulness; it starts with things as they are, and is really a popular contribution to the natural history of man.

On all sides the advantages of observation and the need for the nature-study method in education are being rightly urged, but there is a tendency to narrow the purview. Anything in our environment is worthy of notice, and though attention is well directed towards that which is least artificial, we should not leave man and his works altogether on one side. There is material for observation, research, and deduction, even in a bowler hat and a cut-away coat.

One of the pleasantest features in connection with the making of this book has been the kind and ready help which I have received from all sides. Here and there throughout the text the names of friends and correspondents who have given their assistance have been mentioned. To these I offer my hearty thanks, as well as to the following, who with suggestions, information, or with material for illustrations, have contributed in no small way to the interest of the book: Messrs. Fownes Brothers \& Company, Mr. Allan A. Hooke, Mr. W. S. Ward, 
Mr. Karl, of Messrs. Nathan \& Company, Messrs. Tress \& Company, Messrs. Lincoln \& Bennett, Mr. M. D. Hill, the Rev. A. W. Upcott, Head Master of Christ's Hospital, Miss Clark, Miss Hodgson, the Rev. R. Ashington Bullen, Mr. Henry Miller, of the Church Association, Mr. Ravenscroft, of Messrs. Ede, Sons \& Ravenscroft, Mr. Paley Baildon, Mr. George Hertslet, of the Lord Chamberlain's Office, Messrs. Wilkinson \& Company, Mr. C. M. Mühlberg, Mr. W. S. Parker, of Messrs. Debenhams, Ltd., Capt. H. Trench, Major J. W. Mallet, of The Army and Navy Gazette, Mr. Basil White, of Messrs. Hawkes \& Company, Mr. W. H. Jesson, Messrs. Souter \& Company, Mr. William Lawrence, Mr. Heather Bigg, Dr. J. Cantlie, and the Rt. Hon. Viscountess Harberton.

A glance at the bibliography, which is given on pages $27 \mathrm{I}-3$, will show the principal books and papers to which reference has been made.

In connection with the illustrations, special thanks must be given to Monsieur Maurice Sand, the Editor of The Review of the University of Brussels, for his kind permission to reproduce a number of the figures used to illustrate a translation of Sir George Darwin's article. These are Figures I4, I7, I8, I9, $2 I, 22,23,26,27,30,3 I, 33,46,48,62,63$, and 82. Acknowledgments are due to Mr. St. John Hope for Figures 86-8, to Messrs. A. \& C. Black for Figures I23 and I24 and I32 and I33, and to Messrs. Prewett \& Co. for Figures III and II2.

For the original of Plate II, I am indebted to the kindness of Captain R. Ford, of Plate III to Mr. Henry Stevens ; Plate IV has been taken from a brass rubbing in Rugby School Museum, through the kind offices of Mr. J. M. Hardwich. I have to thank Mr. R. Bamber for the original of Plate VIII, which was obtained through his instrumentality. Figure B of Plate IX was kindly contributed by the Rev. A. W. Upcott, Head Master of Christ's Hospital, and Figures $B$ and $C$ on Plate X were copied from Moseley's "Voyage of the "Challenger,'" by the kind permission of Mr. John Murray, 
while Figure $\mathrm{D}$ is due to the courtesy of General Robley. Plate XI is reprinted from The Reliquary, by the kind permission of Messrs. Bemrose and Sons, and the source of other illustrations is acknowledged beneath them, while the classic collection of pictures which were brought together by the late Mr. F. W. Fairholt to illustrate his "Costume in England" has proved, as will be seen, of the utmost service.

In conclusion, I have much pleasure in calling attention to the time and care which Mr. W. J. Webb has expended upon the figures, which are a feature of the book; and I must mention the willing help which I have been afforded in a number of details by Miss Amy Astbury and Mr. Bernard Weaver.

Odstock, HaNWELl,

WILFRED MARK WEBB.

November, Igo7. 



\section{CONTENTS}

I

THE THRALL OF DRESS PAGE

The principles of evolution applied to clothes . . . . I

II

THE ORIGIN OF DRESS

The origin of dress

III

DEVELOPMENT OF THE MODERN COAT

The ancestral shawl-Problematical buttons . . . I2

IV

BUTTONS AS CHRONICLES

Episodes in the later history of the coat and cuffs . . . I9

$\mathrm{V}$

COLLARS AND BANDS

Nicks in coat lapels-The why and wherefore of the white shirt front . 30

VI

VESTIGES IN THE HAT

How hats were evolved-Why plumes are on the left side-The growth of the busby-Helmets and cocked hats . . . 36

VII

SHOES AND STOCKINGS

Early foot-gear-The origin of the clock-A modern imitation of tattooing-Gaily-coloured garters .

VIII

PETTICOATS AND TROUSERS

The belted plaid and kilt-Early skirts-The antiquity of trousersTrouser stripes

IX

COATS OF ARMS

Signet rings-Armorial bearings-Escutcheons-Crests-Badges 


\section{$\mathrm{X}$ \\ GLOVES AND MITTENS}

Origin of the baby's glove-Fourchettes-The "points" cn" the backs of gloves

\section{XI}

\section{TAGS, PINS, AND BALDRICS}

Laces-The evolution and vagaries of the safety-pin-Primitive methods of carrying burdens as illustrated by muff-chains, baldrics, and yokes

XII

\section{ORNAMENTS}

Primitive necklaces-Finger-rings-The origin of the hair-combButtons-Studs-Flowers-Feathers-Amulets

XIII

\section{HAIR DRESSING}

Head-shaving - Wigs that are still worn-Roman curls and fringes . 92 XIV

\section{SPECIAL DRESSES}

Fashions kept up by ceremonies-Survivals in special costumeFlowing garments

\section{$\mathrm{XV}$ \\ SERVANTS' DRESS}

The prototypes of liveries-Reminiscences of George II and George III -Origin of the page-boy's buttons-The jockey cap-Aprons . 102

\section{XVI \\ COCKADES}

The cockade possibly a degenerated chaperon-The varieties of the cockade-Cockade wearers

\section{XVII \\ CHILDREN'S DRESS}

Survivals in children's dress-Special school-costumes-The blue-coat boy-Public school-boys-Adoption of special dress at girls' schools

\section{XVIII}

WEDDING GARMENTS

The veil-Bridesmaids and bribery-Old shoes-Orange blossom

\section{$\mathrm{XIX}$ \\ MOURNING}

Colours associated with mourning-Widows' weeds-Perennial mourning 
$\mathrm{XX}$

COSTUME CONNECTED WITH RELIGION

PAGE

The surplice and " the cloth "-The civil origin of vestments-Fine vestments-Processional vestments, so called-Nuns' dress-The choker

XXI

SUNDAY CLOTHES

The significance of Sunday clothes-The wearing of hats in church by ladies .

XXII

ACADEMICAL DRESS

Gowns and hanging-sleeves-The forerunner of the hood-The origin of the doctor's hat-The evolution of the mortar-board . . I56

XXIII

\section{LEGAL DRESS}

Vestiges of the coif-Hoods and gowns-Signs of mourning . • I6I

XXIV

STATE AND COURT ATTIRE

Coronation dress-Parliamentary robes-Mistakes in Court Dress-

Vestiges of the wig and of the chaperon-Court cards . . i65

$\mathrm{XXV}$

SURVIVALS IN MILITARY UNIFORMS

Armour-Prickers for flint locks-Forage cords-Reminiscences of gallantry-Regimental badges-Courtship colours

XXVI

\section{NAVAL UNIFORMS}

Supposed survivals-Petticoats and wide breeches . . . I86

XXVII

THE COSTUME OF PUPPETS

Punch and Judy-Fashion dolls-Dolls in swaddling clothes-The Egyptian "shabbies" . . . . . . I88

XXVIII

THE CLOWN AND PAINTING. THE BODY

The clown's dress-Savage painting and survivals of it-Tattooing-

Patches and false complexions-Masks . . . 200

\section{XXIX}

STAGE COSTUMES

The harlequin, pantaloon, columbine, and acrobat . . 2 I0 
$\mathrm{XXX}$

\section{NIGHTDRESS}

Bands on nightgowns-Nightcaps-Night attire worn in the streets . 2 I4

XXXI

\section{THE DRESS OF ANIMALS}

Natural representatives of clothes-Horse-trappings-Amulets on harness-Dogs' disguises-Fashions in the form of animals.

XXXII

COLOUR

Importance of colour-Instinctive love of bright hues-Desirability of coloured clothes and gay scenes-Colour and Complexion .

\section{XXXIYI \\ PATTERNS}

Ancient designs-Checks and tartans-Parti-coloured clothes-Evolution of ornamentation.

\section{XXXIV}

\section{IMPRESSIONS TO BE GAINED FROM DRESS}

Clues from clothes-Individuality not disguised by them-Modern dress of other countries-Significance of clothes

\section{$\mathrm{XXXV}$}

THE EFFECT OF CLOTHES UPON THE INDIVIDUAL

The origin of stays-Tight lacing no new thing-Its effects-Mr. Heather Bigg on the need for support-The ideal foot-Skull deformities-Padding

\section{XXXVI}

FURTHER EFFECTS OF CLOTHES ON THE INDIVIDUAL

Mental effects of different clothes--Preferences of girls for certain articles of dress-Movements that depend upon the presence or absence of clothes

\section{XXXVII}

THE RISE AND FALL OF FASHIONS

Reasons why fashions are followed-Gay clothes seen when periods of depression are over-Condemnation of fashions by the clergyFriends-Sumptuary laws-The killing of Fashions

\section{XXXVIII}

\section{DRESS REFORM}

Clothes to be avoided-Need for warmer garments- " Rational " dress for women

BIBLIOGRATHY 


\section{LIST OF PLATES}

I. Very early man in Java. Illustrating the remarks in Chapter II, page 5

Frontispiece

II. A woman and a witch-doctor of Central Africa, showing the part that ornaments may play even when clothing is of the scantiest. (From a photograph by Captain Ford) .

III. The silk vest worn by Charles I on the scaffold. Illustrating the sleeved tunic opening for a short distance down the front. (From a photograph by Mr. Henry Stevens) . .

IV. Reproduction of a brass to John Brandon and his two wives in the Church of St. Mary, King's Lynn. Date, 1364. On the male figure, a continuous row of buttons runs from the wrist to the elbow of the under-vest. The women wear the wimple and gorget or throat cloth. . .

V. A Siamese Princess wearing trousers
VI. Two Padaung women, showing the numerous metal collars which they wear round their necks . - .

VII. Methods of hairdressing, illustrated by Romano-Egyptian portrait models in the Myers Collection, Eton College. (From photographs by Wilfred Mark Webb).

VIII. A Barge Girl, showing the costume worn on the canals. (From a photograph by Wakefield, Brentford)

IX. Figure A. The cap worn by the scholars of Christ's Hospital until the middle of the nineteenth century. ( $\dot{B} y$ the courtesy of
igure B. A scholar of Christ's Hospital. the Rev. A.W. Upcott, M.A., Head Master of Christ's Hospital)

$\mathrm{X}$. Figure A. The head of a clown, showing the painted face, the ruff and the Elizabethan method of doing the hair.

Figure B. The face of a Japanese actor. (After Moseley, by the courtesy of Mr. John Murray)

Figure c. The painted face of a paper figure which is burned at Chinese funerals. (After Moseley, by the courtesy of Mr.John Murray). The tattooed head of a Moorish chief. (By the courtesy of General Robley) . . . . .

XI. Wooden stay busks. These incidentally show survivals of primitive ornament. (From "The Reliquary," by kind permission of Messrs. Bemrose \& Sons, Ltd.)

XII. The Harem Skirt. - . $\quad$ - $\quad$ - $\quad$ -

Figure A. Walking dress. Figure B. Evening dress. (By the courtesy of the "Country Home") . . 267 xvii 



\section{LIST OF FIGURES.}

nOUKR $\quad$ PAGE

I. Drawing of a woman engraved by a cave man . - 7

2. Sketch showing the development of the tunic. In this stage it has no arms

3. Diagram showing the way in which a sleeved tunic is derived from the shawl . . . . . . .

4. A smock frock.

5. Jacket of a woman, made in one piece. Bronze stage of culture (after Worsaae) . . . . . I5 $_{5}$

6. Man's dress showing buttons on the right side . . . I6

7. Woman's dress showing buttons on the left side . , . I6

8. Diagram showing how a man does up a button. First stage . I7

9. Diagram showing how a man does up a button. Second stage . I7

Io. Diagram showing how a woman does up a button. First stage . I7

Ir. Diagram showing how a woman does up a button. Second stage $I_{7}$

I2. The buttons on the back of a policeman's great-coat . . 20

I3. The buttons that close the slit up the back of an ulster . 20

I4. A back view of a seventeenth-century coat showing the buttons and buttonholes . . . $2 I$

15. The tab and buttons on the back of a soldier's great-coat which make a temporary waist . . . . $2 I$

I6. The buttons and tab on a tramway driver's coat . 22

I7. An eighteenth-century coat with side buttons and tab . . 22

I8. Side tabs and buttons at the back (after Racinet) . 23

19. A coat worn at the end of the seventeenth century (after H. Bonnart) • • • • • • 23

20. A modern coat with side pockets . . . 24

2I. A footman's coat, modern, with vestigial pocket flaps . . 24

22. Coat skirts buttoned back (after Hogarth) . . 25

23. A coat with the skirts buttoned back and showing the lining - 25

24. A dress coat with skirts cut away . . . . . 26

25. A modern coat cuff with buttons . . . 26

26. Turned-back cuff, end of seventeenth century (after Bonnart) - 27

27. A coat sleeve (after Hogarth) with horizontal row of buttons - 27

28. Sleeve of a coat of the seventeenth century, reputed to have been worn by Charles I. - . . 28

29. The turned-back cuff on an overcoat, modern . . 28 
FIGURE

30. A sleeve with vertical buttons and a turned-back cuff as well (from a uniform, after Hogarth) . . . 28

31. The uniform of a coastguard officer of I775 (after Racinet) . 29

32. The nicks in the coat and waistcoat . . . $3 I$

33. A stage when the nick was useful (Lucien Bonaparte, after Paul Lacroix) . . . . . . . $3 x$

34. The "toothpick" on a dress coat . . . 32

35. Modern bands . $\quad$. $\quad$. $\quad$. 32

36. A blue-coat boy's bands . . . . 33

37. A chorister of Jesus College, Cambridge, showing the collar worn until recently. (From a photograph, by the courtesy of Mr. H. Austin Wheaton) ? . . . 33

38. A stage in the reduction of bands (portrait of Jan Steen from The Illustrated Magazine of Art)

39. Full-sized bands (portrait of John Pym from The Illustrated Magazine of $A r t$ )

40. A modern bandbox, now used for hats

4. Bands that survive at the present day * * 34

4r. Bands that survive at the present day . • . . 34

42. The turban of a Jewish priest (after Kitto) compared with the dome of the Mosque of Omar

43. A Siamese head-dress and a Pra Pang or votive spire (after P. A. Thompson)

44. A Gothic spire (St. Stephens, Caen) compared with the hennin (the latter after Fairholt).

45. Band with streamers fastening on the head-dress of an Egyptian womañ. From a figure of the Sixth Dynasty, 3500 B.c. .

46. A lady's head-dress confined with a fillet, fourteenth century (after Viollet le Duc)

47. A sailor hat with band and streamers . . . .

48. A modern Scotch cap with streamers.

49. A twelfth-century head-dress with streamers, from a MS. (after Viollet le Duc)

50. A mitre of the See of Durham showing the strings (after Millington)

5I. Small vestigial bow of ribbon in a modern hat .

52. A hat with the remains of lacing . . . . 42

53. A hunting hat with complete lacing inside . . . 42

54. A disc of leather . . . . . . 43

55. The disc perforated and the lace inserted . . . 43

56. The lace tightened to form a crown . . . . 43

57. The ends of the lace tied as a bow inside . . . 43

58. A bow fastened to the lining of a lady's hat . . . 43

59. Plumes on the left side . . . . . 43

6o. The red Hungarian cap, which was the forerunner of the busby . 44

61. A busby (of the Honourable Artillery Company) in which the cap is a vestige only $\quad . \quad \cdot \quad \cdot \quad 4 \quad 44$

62. A fireman's helmet (of the ancient Greek type) . . . 45 
PIGURE

63. Buttons so arranged that the broad brim of a hat can be fastened to the crown, thus forming a temporary " cock" (Hudibras, after Hogarth)

64. A modern boot decorated with perforations made in the leather .

65. An ornamented Roman shoe, of two thicknesses . . . 47

66. A Roman shoe of open-work leather . • • • 47

67. A hide shoe of pre-Roman type from Ireland (after Fairholt) - 48

68. The original top boot with the upper part temporarily turned down 49

69. A modern top boot in which the upper part can no longer be

70. Puttees turned up.

7I. Leg bandages of a royal personage at the end of the tenth century (after Fairholt)

72. A stocking with a clock

73. An embroidered stocking showing the further evolution of the clock (date 1900)

74. An open-work stocking of 1905

75. A shawl used as a kilt by a chieftain of Denmark in the bronze stage of culture (after Worsaae)

76. A simple dress in the form of a petticoat from an Egyptian figure of the Sixth Dynasty ( 3500 B.C.), from the Myers collection at Eton College

77. A Korean servant (after Hough)

78. A short kilt

79. A barbarian soldier wearing characteristic trousers (from a diptych of St. Paul, after Marriott)

80. A Saxon military man wearing wide trousers (from the Harleian MS., No. 603, after Fairholt)

81. A peasant woman of Champéry wearing trousers

82. A German Hussar of 1808

83. The crest on a modern signet ring

84. Sir Geoffrey Loutterell and the ladies of his family, showing the extent to which armorial bearings were worn in the middle of the fourteenth century. From a psalter, made for Sir Geoffrey (after Fairholt)

85. The crest and surcoat of Henry, first Duke of Lancaster, A.D. I347. From the brass to Sir Hugh Hasting at Elsyng, Norfolk (after Charles Boutell)

86. The helmet and crest of the Black Prince. From "Vetusta Monumenta " (after St. John Hope)

87. The shield of the Black Prince. From "Vetusta Monumenta" (after St. John Hope)

88. The surcoat or jupon of the Black Prince. From "Vetusta Monumenta" (after St. John Hope)

89. The postilion of a Lord Mayor of London, wearing a crest upon his cap, and a coat of arms upon his sleeve (copied by permission from a plate published by the John Williamson Co., Ltd.) 
91. The back of a woollen glove showing the three vestiges known as "points" .

92. A modern kid glove showing the fourchettes or pieces between

the fingers, which form three pointed V's . .

93. Queen Elizabeth's coronation glove, showing the stitching carried down on to the back. (From a photograph by the courtesy of Messrs. Fownes Brothers and Co.)

94. The glove of Anne, Queen Consort of James I, showing the embroidery on the fingers, which is the ancestor of the modern "points." (From a photograph, by the courtesy of Messrs. Fownes Brothers and Co.).

95. A silk lace with simple metal tags

96. Ornamental metal tags on a velvet neck ribbon

97. A simple safety-pin

98. An Etruscan brooch or fibula, resembling a safety-pin. (In the collection of Major W. J. Myers in Eton College Museum) .

99. The safety-pin in the waistband

100. The safety-pin grown larger and used for fastening on a hat

Ior. A muff-chain . . . . . . . . 77

102. A hawker, illustrating the primitive way of carrying a burden . $\quad 7^{8}$

103. A courier-bag supported by a baldric . . . . 78

104. An ornamental baldric of the early fifteenth century. (Royal MS. I5, D. 5, after Fairholt)

70

I05. A lady's dress, showing the part which is called a yoke, and recalls a primitive method of carrying burdens

106. A loom comb found in the Glastonbury lake dwellings (after Boyd Dawkins) .

107. A modern comb for the hair .

108. Two studs of bronze, seen from above and from the side, later Bronze Age (after Worsaae)

Iog. The "flash" of five black ribbons on the collar of the Welsh Fusiliers. A survival from the days of the pigtail .

Iro. The modern groom, showing the belt to which ladies clung when riding on a pillion.

III. A footman in plush breeches and with powdered hair. His "pouter" coat dates from the reign of George III. By the courtesy of Messrs F. T. Prewett and Co. .

112. A sheriff's coachman with the full-skirted coat of the time of George II. By the courtesy of Messrs. Prewett and Co. .

II3. The wig-bag (a survival of the bag-wig) now seen on the back of the collar of the Lord Mayor's coachman . . . Io6

II4. A modern page-boy's livery . . . . . I07

II5. The Dutch skeleton dress, fashionable for boys in I826 . . I07

II6. The cockade known as the "large treble," representing a survival of the chaperon

Ir7. A " treble cockade " covered with black cloth for mourning. The concentric circles would appear to represent the twisted liripipe of the chaperon 
II8. Treble cockade used by Chelsea pensioners . . . . II3

I19. The Regent cockade

120. Royal cockade for state occasions

121. Ordinary Royal cockade

122. Two stages in the evolution of the chaperon. Combined hood and cape . $\quad$. . . .

123. Enlargement of the Peak of the hood to form the liripipe. (After Calthrop, by kind permission of Messrs. A. and C. Black) .

124. Further development of the chaperon. Cape and liripipe made into a head-dress that can be altered at will

125. A chaperon ready made up, in order to save trouble. (After Calthrop, by kind permission of Messrs. A. and C. Black) .

126. Dress worn by the girls at Coombe Hill School, King's Langley It is a modification of the Dervish Djibah .

127. Dress worn by the girls at the Croft School, Fleet, when at work

I28. St. Gregory the Great with his father Gordianus, who was a senator, on his right, and his mother Sylvia on his left. This shows the similarity between ecclesiastical and civil costume in early times. From an authentic picture (after Marriott) .

I29. A priest in the vestments now worn at the celebration of the Eucharist .

I30. The coat of arms of Thomas a Becket, showing an archbishop's pall

I3I. The head-dress of a nun showing the veil and breast-cloth derived from the wimple, the cap which represents the chin-cloth, together with the frontal and the hood

I32. The head-dress of a lady of the time of Henry II. The wimple is shown covering the chin and head-bands (after Calthrop).

133. The chin-band and forehead strap after the wimple has been removed (after Calthrop)

134. Hanging sleeve of the fifteenth century . . .

135. The hanging sleeve of a Chancellor of Oxford University .

136. A college cap or trencher

- I $^{\mathrm{I}}$

I57

158

I 59

137. Cranmer's hat, illustrating a stage in the evolution of a mortarboard (after Fairholt)

I38. The hat of a bishop of the Stuart Period showing a stage at which the stiffening now seen in the mortar-board was becoming necessary (after Fairholt)

139. The wig of a modern judge

I40. The vestige of the coif from the wig of a serjeant-at-law .

I4I. A barrister's gown showing the vestigial hood and its streamer. The buttons and braid which once temporarily looped up the sleeves now fix it permanently

142. A Yeoman of the Guard of Edward VII.'s reign

143. The wig-bag or " flash " from a Court suit, showing the rosette held away and displaying the black silk bag. At the lower corners of the latter loops are seen, which are probably the remains of those through which a ribbon was passed, which went round the neck and fastened on the breast by a brooch 
FIGURE

I44. The hood from the mantle of a Knight of the Garter, showing the survival of the chaperon and its liripipe

145. Relic of chain mail on the shoulder of an Imperial Yeoman .

146. Chain mail illustrated by the brass of Sir Richard de Trumpington, A.D. 1289

147. A reversion in military equipment. One of Cromwell's Ironsides (1649), from a print. A Cavalryman sketched at Aldershot in I9or. Copied, by permission, from The Daily Mail.

148. The prickers on the shoulder-belt of a Hussar, which survive from the time of flint-lock muskets

I49. The Oscan Pulicinella of I73I, without a long nose. The dress is very similar to that figured in 1630 (after Riccoboni) .

150. The Calabrian Giangurgolo of $\mathrm{I} 73 \mathrm{I}$, with the long nose. The dress is very similar to that figured in I630 (after Riccoboni) .

I5I. An ancient bronze statuette with the face and features of Punch (after Ficorroni)

152. A fourteenth-century puppet-show (from the MS. of the "Roman d'Alexandre ")

I53. Punch, from the Punch and Judy Show, showing the ruff and other details of Elizabethan costume

I54. Judy, from the Punch and Judy Show, with ruff, mob cap, and apron

155. The Beadle, from the Punch and Judy Show

I56. The Doctor, from the Punch and Judy Show, with wig and white tie

I57. A clown, showing a survival of an Elizabethan costume . . 20 I

I58. The dress of a modern harlequin . . . . 2 II

I59. A pantaloon, showing an Elizabethan costume of which Venetian breeches form part

r6o. The bands that survive on a lady's nightdress . . .

I6r. A woman's nightcap, still worn in Wiltshire . . .

162. A man's nightcap, from Oxfordshire . . .

163. An English horse amulet in the form of a crescent. The flat places near the tips of the horns may be evidence that the form is derived from two boars' tusks

164. An English horse amulet showing both the heart and the sun .

165. The cowry-shell ornaments on the head of an officer's charger of the Ioth Hussars. The pendant recalls that on mules in Palestine

166. Cowry shells on an Eastern mule, hanging like the pendant of the roth Hussars

167. Cowry shells on the head-stall of a camel from Palestine .

I68. A Merveilleuse (after A. Robida) A taller daughter, and the puny boy (from a drawing by Miss Audrey Watson in "Physical Efficiency," by Dr. Cantlie, by kind permission of Messrs. Putnam's Sons) 
THE THRALI OF DRESS

THE PRINCIPLES OF EVOLUTION APPLIED TO CLOTHES

The numbers in the text refer to a bibliography at the end of the book

TNLUCKILY perhaps, we are born naked and helpless, but no sooner do we come into the world than we are provided with body-guards in the shape of clothes. In consequence, our social position is made manifest. Our vanity is flattered at the same time that our modesty is assured. On the other hand, however, our skin may be chafed, our hair worn away, and, should our equipment strictly follow the dictates of the Goddess Fashion, our bodies may even be deformed and our lives shortened. Moreover, there are other penalties to be paid; we are kept warm in summer as well as in winter, the purchase of our attire may entail the spending of much money, while the mere donning and doffing of our clothes gives rise to a prodigious waste of time.

Even tramps have at intervals to replace the rags which cover them, and while, for all practical purposes, everyone else takes off his clothes when going to bed and puts them on again when getting up, many of those who are at work in the daytime "dress for dinner" in the evening. Moreover, Society may demand a further expenditure of time on the part of its members, and the rule may be laid down that the higher the standing of a civilized individual, the more often does he change his 
garments. In fact, more than one monarch, from the way in which he appears in different uniforms at various functions which follow one another in quick succession, has been likened to the now faniliar "lightning change artist" of the musichall stage.

It is thus quite clear that all of us are more or less under the thrall of dress. Those, therefore, who find the position irksome, will gain solace from the interesting investigations which can be made into the origin and development of costume. Others, again, whose clothes already find favour in their eyes, will enjoy looking at them from a different point of view.

As a matter of fact, our artificial coverings have become so much a part of our life that one may perhaps be allowed to apply the methods of the naturalist to their consideration, and deal with them as if they were part and parcel of the creature which wears them.

Darwin established beyond a doubt ${ }^{1}$ that the plants and animals of to-day are the direct descendants of older and often very different forms, and it is the task and delight of the naturalist to trace their genealogies. Most useful suggestions may be obtained from the small vestiges that remain in the bodies of present-day creatures of structures which in early times were important and useful organs.

For instance, if the skin be lifted from the head of a "slow worm "we find a third eye, which tells us that once its ancestors, like the giant Cyclops, were able to look out from the middle of their faces.

Again, to take a case which applies to ourselves, and has a melancholy interest for us, one might mention the vermiform appendix. This is a remnant of a great sac which once was useful when our ancestors were vegetarians; now it is worse than useless, for it is very liable to become irritated and give rise to what is known as appendictis.

So long as a quarter of a century ago Sir George Darwin pointed out ${ }^{2}$ that the great theory of evolution established by 
his father could be applied with much advantage to the study of dress, and it will be seen as we proceed that not the least fascinating part of the subject are vestiges similar to those which we have just described, and which have often survived solely for ornamental reasons.

Many of these are so familiar, that in running the eye in the ordinary way over a man's usual costume, attention would not be drawn to them. There is the band round the outside of his hat and the little bow inside; the nick in the collar of his coat and the more or less useless buttons on his sleeves and back; while we must not forget the curious ornamentation on the toes of his boots, nor the crest on his signet ring.

When, however, an indication is given of the times and peoples to which these trivialities can be made to carry us back, interest is aroused to a remarkable degree. It can also be well maintained, for other clothes present similar quaint survivals for investigation, while the evolution of many individual garments is worth following, and special costumes have been handed down to the present day, practically unchanged.

Fortunately, the student of dress is in a much better position than the naturalist proper. The evidence available when the history of an organism in past ages is being unravelled is very scanty in many cases. Sometimes the fossil remains recovered from the earth are very perfect and follow one another in unbroken succession, but they usually consist merely of the hard parts of the creatures. The individual development of an organism is also a help, but when the changes which have taken untold ages to perfect are repeated, as in the case of the chicken in the egg, within the space of a few short weeks, it is not surprising that much is left out and obscured.

Man has existed in a civilized condition for a comparatively short time, and there remain all kinds of records and illustrations, not to mention actual clothes themselves, which can be consulted or examined. Moreover, primitive men in almost every stage of culture are, or were till quite lately, to be found 
somewhere in the world, and much can be gleaned from them as to the origin and uses of costume.

There is a point that may be borne in mind when seeking for curiosities of clothing, and it is that the more special or ceremonial the occasion, the more ancient or more primitive the costume which is worn. In this connection also it may be mentioned that the dress of the master of one generation may survive as that of the servant in another. 


\section{THE ORIGIN OF DRESS}

\section{Both he and his people were black as sloes For the region they lived in was torrid, And their principal clothes were a ring through the nose And a patch of red paint on the forehead.}

THOMAS HoOD THE YOUNGER.

$\mathrm{I}^{\mathrm{N}}$ seeking the origin of dress we necessarily assume that 1 once upon a time our primitive ancestors did not wear any clothes at all. Even nowadays, in our own country, at sports, in the ball-room, and on the stage, the garments worn, or some of them, may be reduced to the minimum that the rules of Society appear to demand. There are, moreover, two reasons why very early man did not trouble to dress : first of all, he was covered with hair like the majority of mammals (see Plate I., Frontispiece), and, secondly, it is more than probable that his home was within the tropics. The two ideas are quite compatible, for all the great apes-chimpanzee, orang-utan, and gorilla-which are the nearest relatives of man, have been found in the warmer regions of the world, and are well supplied with hair.

It has long been thought that the cradle of mankind is to be looked for in the south of Asia, and it is a striking fact that of recent years the bones of the earliest known creature with really man-like characteristics (Pithecanthropus erectus) were discovered in Java. ${ }^{3}$ It appears, however, that Pithecanthropus, although it walked erect, approximated more closely to the apes than does any more recent human being, and in making a restoration of the type in question, one would 
feel bound to endow it with a coat of hair. This has since been lost, and, according to Darwin, owing to æsthetic reasons, the members of one sex having chosen as mates those of the other who were the least hairy.

Man also has found his way into most parts of the globe, but he has not always acted with regard to dress in the same way in similar climates. The problem, therefore, which we have set ourselves to solve, proves to be less simple than it appeared at the outset, for great use may be made of clothes in one cold country and not in another, while they may be unknown in certain parts of the tropics, and adopted elsewhere within them.

Very often when it is sought to explain a matter, it is found that this can be done in two or three different ways, and it is quite possible that all of them may be correct. This fact may with advantage be borne in mind when seeking for the reasons which lead to the adoption of dress, for the first time, by any particular race.

Perhaps it will help us if we pause for a moment to consider why clothes are worn at the present day. There is no doubt but that in the case of many garments, their ornamental character, real or supposed, is the first consideration. Others are chosen chiefly for protection and warmth, while, as already indicated, the rest suffice to satisfy the claims of modesty. Although the three reasons are now intimately combined, it is practically certain that any one of them is sufficient to have led to the adoption of clothes in the first place, and as if these were not enough there may be other contributing, if not actual causes.

We may now consider these matters in detail. It would seem from the study of modern peoples, who are still in a very simple state of civilization, as well as from one of the earliest drawings scratched by the cave-men who were contemporary with the mammoth in France, that ornaments are the most primitive part of dress. (See Figure I and Plate II.) 
Generally speaking, the more simple the race, the greater is its love of ornament. The cave-man's sketch shows a woman who is devoid of clothing, but who wears bracelets, while it is said that in the original a necklace can be traced, though owing to an injury to the fragment of bone on which the drawing was made, the head of the figure has been lost.

On the West Coast of Africa, where clothes are not a necessity, owing to the heat, bracelets are worn in such numbers by the native belles as to cover a large part of the forearm, while

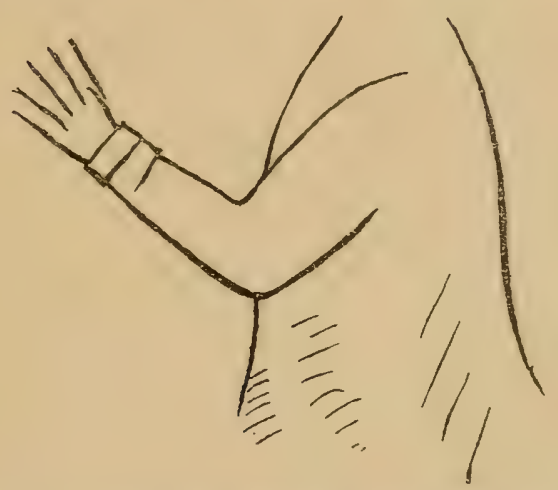

FIGURe 1.-Drawing of a woman engraved by a cave-man. (Modified from Wilson.)

anklets rise in succession nearly to the knee. In other parts of the same continent we find similar instances where ornaments are more important than clothes. (See Plate II.) Again, in New Guinea the women of some tribes who do not indulge in a single scrap of clothing still wear ornaments on their heads and round their necks.

There is, however, something to be advanced on behalf of savages that cannot be said for white people who bedizen themselves with jewellery, or bedeck themselves with the feathers of rare and beautiful birds. Uncivilized people have no pockets nor safes in which to keep their valuables, and it comes about that these take a form which permits them to be 
worn on the person, so that many of the objects which take the place of ornaments-such as teeth, shells, and beads-serve as the currencies of their owners. Even now there are individuals of whom it is said that they "put all their money on their backs," but, unfortunately for them, it depreciates sadly in value, and cannot be turned to account at a moment's notice. Furthermore, one naked warrior is very much like another, and chiefs, in order that they may easily be identified, have come to wear certain ornaments just as, at the other extreme with regard to covering, knights in full armour carried crests on their helmets and other devices on their surcoats and shields.

Clothes proper are of later origin, and, as we have already mentioned, would only be adopted for protective purposes, after man had lost the greater part of his hairy covering.

It is probable that this had happened before the earliest settlers arrived in this country, although the cave-men made their drawings of themselves in the nude, and it is contended that the marks on their bodies are similar to those in the drawings of animals and are not mere attempts at shading, but indicate the presence of hair.

In the first place, man was a hunter pure and simple, and his clothes were made from the hairy skins of his quarry. At the present time the Eskimos are clothed in this way, and there is little doubt but that they are the descendants of the cave-men, who made the striking drawings to which we have already alluded. Their implements, stature, and so forth all point this way, and the fact that their clothes are merely adopted as a protection against the weather is shown by the fact that they remove them altogether when in their huts.

We have already said that it does not always follow that even when the climate is cold, complete dress is brought into use. When H.M.S. Beagle visited South America, some of the Tierra del Fuegians wore only an otter skin or some small scrap about as large as a pocket-handkerchief. It was laced across 


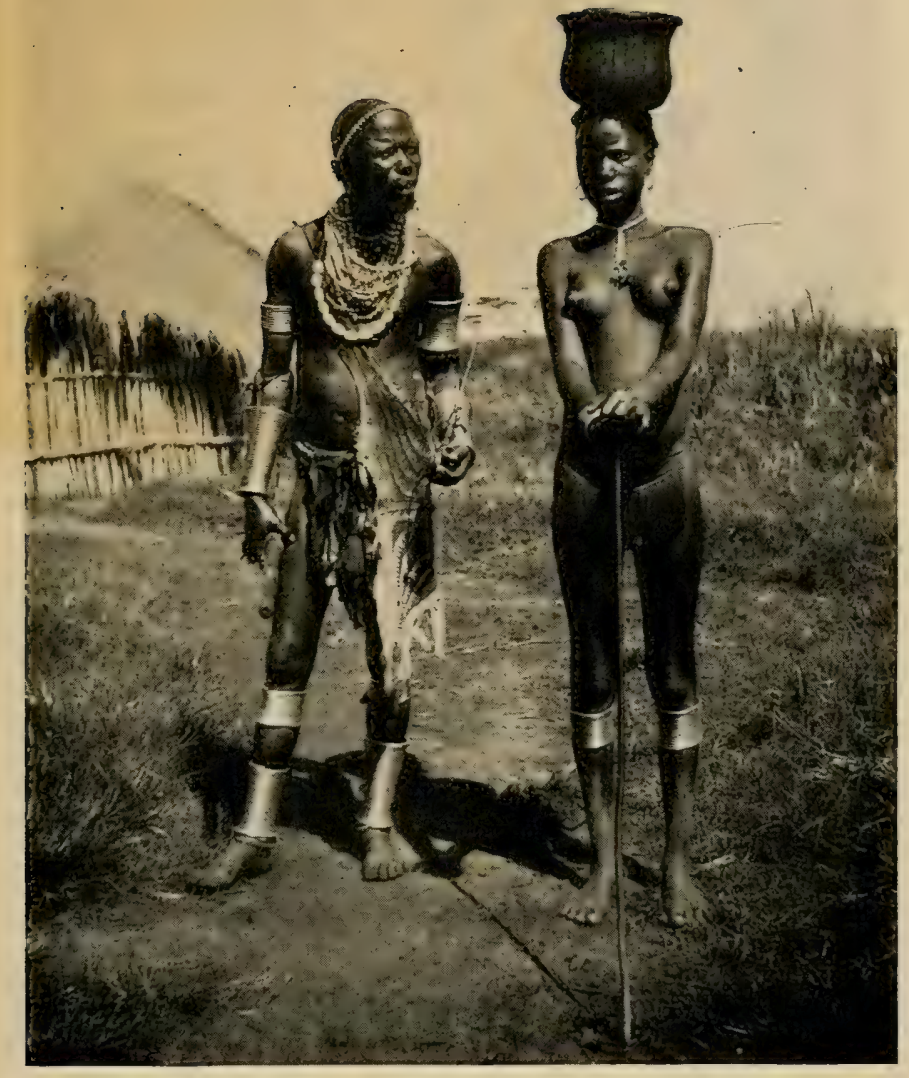

A IVOMAN AND A WITCH DOCTOR OF CENTRAL AFRICA, SHOWING THE PART THAT ORNAMENTS MAY PLAY EVEN WHEN CLOTHING IS OF THE SCANTIEST. (See page 6.) (From a photograph by Captain Ford.) 

the breast by strings, and was shifted from side to side according to the direction of the wind. Others, both men and women, wore nothing. One of the latter, who was suckling a recently born child, came alongside the vessel in a canoe, and stayed there, out of pure curiosity, while the sleet fell and thawed on her naked bosom and on the bare body of her baby.4

Some races can make very passable clothes by hammering the fibres from the bark of trees into a kind of cloth, while when men took to husbandry and cultivated plants that produce fibres, they learned also to spin and weave materials, from which to make their garments. The use of furs has always survived to a greater or less extent, but it is interesting to note that motoring has caused a return to primitive dress as regards external garments, for in order to withstand the air which is met when the car is in rapid movement fur clothes and leather suits have been introduced, the latter of course being not quite so old in type as the former. It must not be forgotten at this point that climate is not the only enemy that man has had to face, and that armour was a development of dress, intended to preserve him from the onslaughts of his own species.

We have now noticed two ways in which clothes must have been brought into use, namely, as adornments and for protection. We have still to consider the third of the obvious reasons. Modesty is a habit, or one might perhaps call it equally well a fashion, which is so widespread that some have characterized it as being an instinct, and have stated quite wrongly that it is universal. The most curious point with regard to the matter is that very different ideas of modesty prevail in various regions of the world, one part of the body being covered by some people and another by others. Besides, it by no means follows that a naked race is less chaste than one which is clothed.

Although at the present day races exist where only the men cover themselves, it is very likely that clothes worthy of the name were first worn by women, for keen observers have pointed out that men dependent on their skill and speed in 
the chase would hardly encumber themselves with clothes, though having comely wives they might deem it advisable for them to be protected from the public gaze. This idea is still carried out in Eastern countries, where women cover even the greater part of their faces, and are usually secluded in a harem. As bearing out, however, what we have just said with regard to modesty, it may be mentioned that the peasant women in Egypt are perfectly happy so long as their faces and the backs of their heads are covered, and it is considered even more shameful to expose the latter than the former. The objection made not long ago to the appearance of English women in church without hats may be remembered in this connection.

Painting may often replace clothing, and members of races accustomed to decorate their bodies in this way are much ashamed if they are seen unpainted. Tattooing also does away to a great extent with bareness, and it is obvious that unclothed black men and women never present such a naked appearance as do lighter-coloured races. In fact, a white man who bathed with a number of coloured people likened himself and his companions to an artificial, blanched, and sickly plant among its healthy dark green fellows.

Doubtless the hair of original man was coloured so as to match his surroundings, and it seems likely that the tint of his skin was reddish. We have now no need for protective colouration (except in war time), and as we do not live in the tropics, we should gain no advantage from being black; therefore pigment is but little developed in our skins, and it has been suggested that clothes sometimes have been adopted by white races for æsthetic reasons apart from their development from ordinary ornaments.

It seems possible, too, that man, upon realizing that he differed from other animals in having no natural covering, set about to provide himself with one.

There is, however, another contributing cause which may have led to the adoption of dress, and this depends on the 
action of women themselves. They may put on clothes for reasons of coquetry just as on occasion they may modify or discard them. For instance, fashion at a moment's notice may obscure one part of the body that hitherto was obvious, and at the same time emphasize the natural outlines of others which before were hidden. Again, the bare necks and arms displayed in our ball-rooms afford another case in point. 


\section{III}

\section{DEVELOPMENT OF THE MODERN COAT}

\section{THE ANCESTRAL SHAWL-PROBLEMATICAL BUTTONS}

NOW that we have considered the origin of dress as a whole, I we may turn with advantage to the evolution of individual garments. People are very often pleased to allude to what are called the vagaries of fashion, but it is curious to notice how little important change is made in costume at the present time. The really useful characters are always retained, and our modern clothes can be reduced to a very few types. A skirt is a skirt whether it falls naturally, is held out all round with a hoop or crinoline, or is only supported behind by what at one time was known as an "improver." And in the same way it may be said that trousers remain trousers whether they have bell bottoms or are peg tops.

Even types which we recognise as being quite distinct are often so closely related as to cause surprise when their family history is made known. Although it constantly alters as regards details, which from a constructional point of view are

- quite unimportant, woman's dress does not seem to have varied to any very great extent. Consequently, there are not quite so many curious features to be seen as in the ordinary clothes or uniforms of men. On the other hand, however, we may with greater reason hope to find that some primitive characters have survived until the present day. 
No article of clothing could well be simpler than the shawl, and though there is an art in its arrangement, the only point in its structure that would appear to invite attention is the

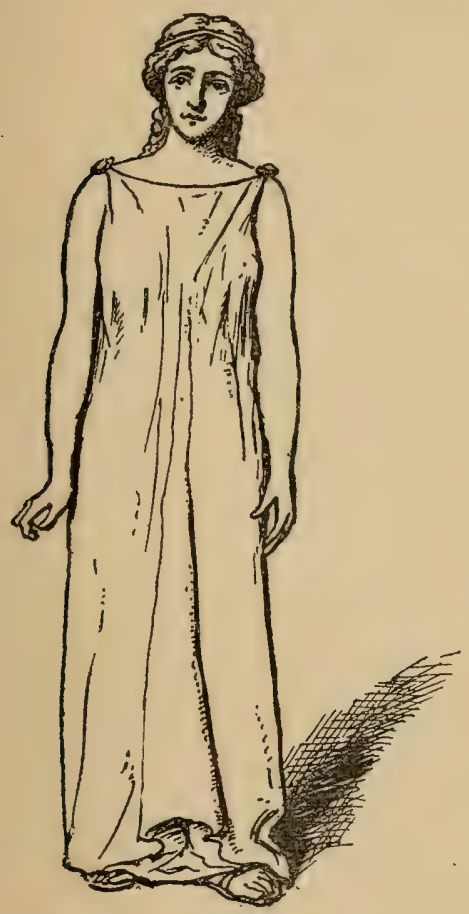

FIgure 2.-Sketch showing the development of the tunic. In this stage it has no arms. presence of a fringe on only two sides. This seems to be a. small matter, but it takes us straight back to the time when men had ceased to be hunters merely, and having become agriculturists had learned, as we have already indicated, to weave fibres with the help of simple looms. From the cloth thus made clothes were constructed, though skins continued to be used as outer mantles. When the stuff was taken from these early looms, the threads of the warp were left hanging from two opposite edges, probably to prevent fraying, and the fringe that we have now on our shawls is a direct survival of this.

There seems not the slightest doubt but that we can trace the coat from the shawl. A simple improvement in the latter is to join two edges of the shawl together and make a tunic. Such a tubular garment was used in Greece, and, with some slight modifications, is worn by Egyptian women to-day. It came up to the armpits, was gathered up on to each shoulder and fastened with two brooches. (Figure 2.)

The next stage in development would be a sleeved tunic, and how easily this could be derived from a shawl can be seen 
by putting a narrow one over the shoulders and lifting up the arms as shown in Figure 3. The material has only to be sewn together under the arms, and, if necessary, cut into shape.

If the front be not sewn up, we get the coat as we know it; if the edges be joined along half their length or more, then we have a sleeved tunic, a shirt, or vest. (See Plate III.) The smock-frock (see Figure 4) and gown are more voluminous, while the jersey is short again, and has only a small opening at the neck. An interesting garment is found among the costumes of the Bronze Age chieftains of Denmark and their wives, which have been preseryed in the oak coffins of these people, owing to the action of tannin from the wood which has preserved the woven material. ${ }^{5}$ The article in question belonged to one of the women, and though the front edges are joined for a short distance, it is practically a jacket. The sleeves are made all in one piece, and the garment is very nearly as highly evolved as the Cardigan jacket, which it very much resembles. (See Figure 5.)

It is by this time clear that several important garments are the descendants of the shawl, which is still used by men in the British Isles under the title of the plaid, or maud.

Though differing, of course, in detail, the upper garments of men and women agree in general construction. One of the

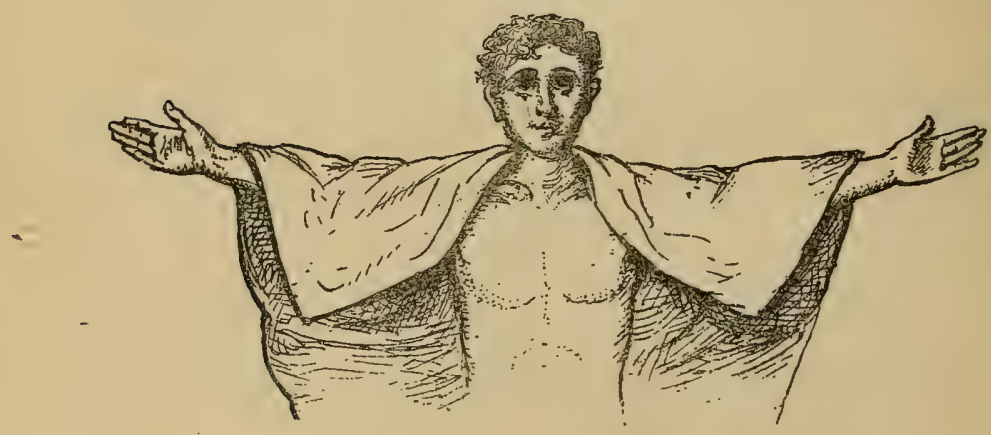

FIGURE 3.-Diagram showing the way in which a sleeved tunic is derived from the shawl. 


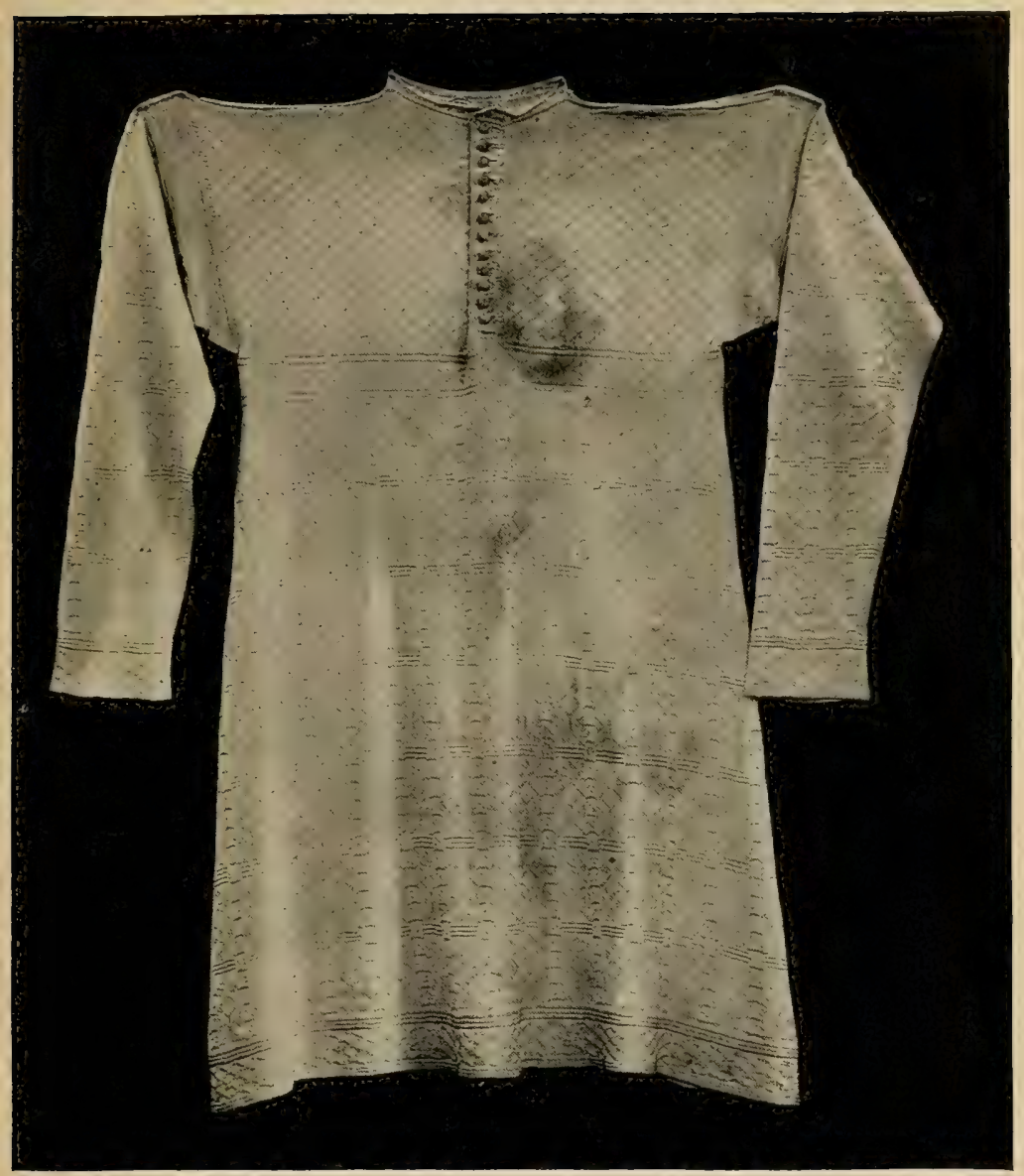

THE SILK VEST WORN BY CHARLES I ON THE SCAFFOLD. ILIUSTRATING THE SLEEVED TUNIC OPENING FOR A SHORT DISTANCE DOWN THE FRONT. (See page I4.)

(From a photograph by Mr. Henry Stevens.) 



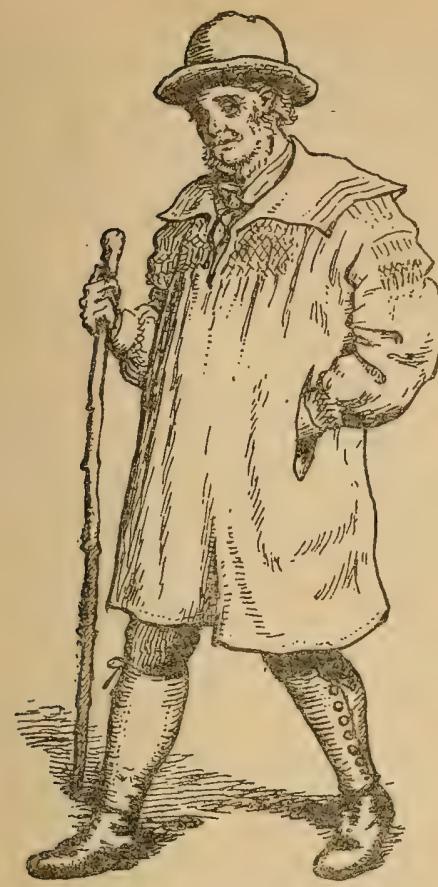

FIGURE 4 ,-A smock frock.

hand, puts his left thumb into the buttonhole and pushes the button against it. Then he pulls the stuff over with his right forefinger and pushes the button through with his right thumb while he guides it with his left.

The woman, on the other hand, puts her right thumb through the buttonhole, takes hold of the button with the (after Worsaae). points alluded to is worthy of mention, namely, that the buttons on a man's coat are on the right side (see Figure 6), and the buttonholes on his left, while in the case of women's attire the exact opposite is found (see Figure 7)-at least, so far as one can ascertain - in European countries. In the East, the little knobs which are passed through loops and take the place of buttons, may in the women's dress be on the right side, and in other Asiatic costumes the same thing holds good. In connection with this peculiarity, it may be pointed out that men and women have different ways of doing up buttons. The man takes hold of the button with his right

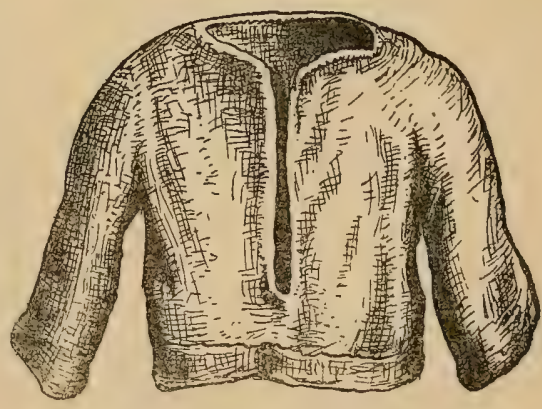

FIGURE 5.-Jacket of a woman, made in one piece. Bronze stage of culture Bronge stage of culture 


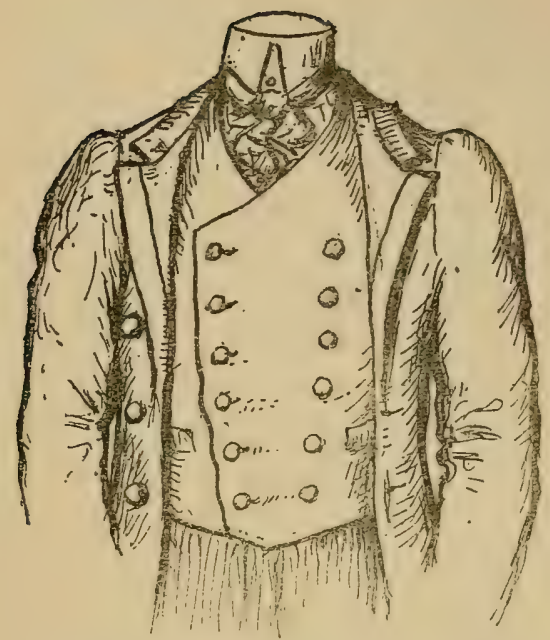

Figure 6.-Man's dress showing buttons on the right side.

fingers of the same hand, and finally, if the other hand is at liberty, brings it up to finish the process. (See Figures 8 to II.)

To explain the difference in the position of the buttons is not by any means easy. In the correspondence which has arisen out of lectures which the writer has given on the evolution of dress, it has, in the first place, been suggested that the arrangement of his clothing permitted a man to thrust his right and

fighting arm into his jacket in order to keep it warm. This explanation, of course, does not account for the variation in the case of women.

Dr. Lyman, of Baltimore, has submitted the theory that a man wearing a loose cloak, toga, or plaid, would grasp it with the left hand and thrust the left side over the right so as to leave the right hand free $_{\mathscr{E}}$ in order to

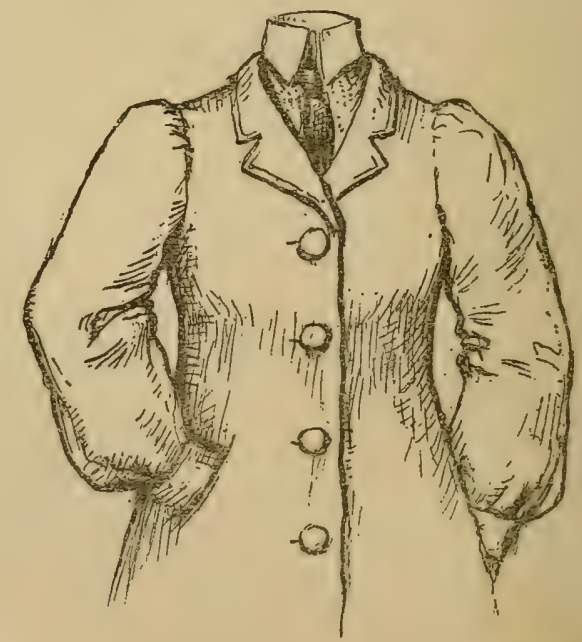

FIGURE 7.-Woman's dress showing buttons on the left side. 
To turn to women's dress, it is customary, as Dr. Lyman says, to carry children on the left arm, and they are allowed to suck the left breast to a greater extent than the other. The left side of a bodice could, if the right lapped over it, be pulled back without exposing so much of the person as if the reverse held good, and in the case of tightly-fitting clothing, if the buttons have to be done up with the right hand alone, the task is made easier. Another interesting little point of difference between the clothes of the two sexes is, that while the buttons on a man's wristbands are on the thumb side, those of a woman are on that which corresponds with the little finger. This arrangement is no doubt correlated with that previously discussed, but the reason for it is not obvious. 


\section{IV}

\section{BUTTONS AS CHRONICLES}

EPISODES IN THE LATER HISTORY OF THE COAT AND CUFFS

$W^{E}$ have gained some insight into the development of garments as a whole, and no doubt it is now obvious that the little details of construction will prove by no means the least attractive part of our subject. It has become customary to refer to a button as typifying something of specially small account, though very often much may depend in practice upon one of these despised articles.

We have already shown that the mere position of a few buttons that are still useful may raise most curious points, and in the present chapter we shall proceed to investigate some episodes in the later history of the coat which have left their mark upon it, to a great extent in the shape of useless buttons. This topic will be dealt with in some detail, so that it may serve as a guide to those of our readers who may be induced to undertake the fascinating study of survivals in dress. Afterwards, the general survey of modern clothes will be continued, and here and there lines of research will be indicated, while some problems will be left for our readers to solve. In the second part of the book, it is intended to deal with a certain number of costumes which have been handed down to us as they are.

At the present time there are usually to be seen two buttons on the back of civilians' coats, except in the case of lounge 
suits and dinner jackets and there may be four or more on the great coats of policemen (see Figure I 2 ) and on the tunics of some soldiers. The first question

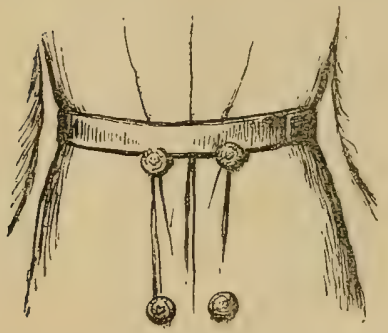
which we will endeavour to answer is, Why are they there?

The two upper buttons in the case of uniforms are now used to support a belt, and at first sight it looks as if they were originally intended for this purpose. Their adoption in other cases might

Figure I2.-The buttons on the then be put down as a survival back of a policentan's great coat.

from a time when civilians carried swords. Unfortunately for this theory, it can be shown that the sword-belt was not necessarily worn outside the coat. (See Figures I8 and I9.)

We must therefore look round for further evidence, and we find that those coats which bear the pair of buttons have a slit up the middle which gives rise to the skirts or tails. This arrangement carries us back to the time when there were no railways and few conveyances; when men commonly travelled on horseback and their whole attire was adapted to this end, so that they were ready for the saddle at a moment's notice. The division in the coat which we are considering allowed one tail to fall con veniently on each side of the

- horse after its rider had mounted it.

In long overcoats of to-day we find only a short slit, left for convenience in walking (see Figure I3) ; but it has a special interest for us, as in connec-

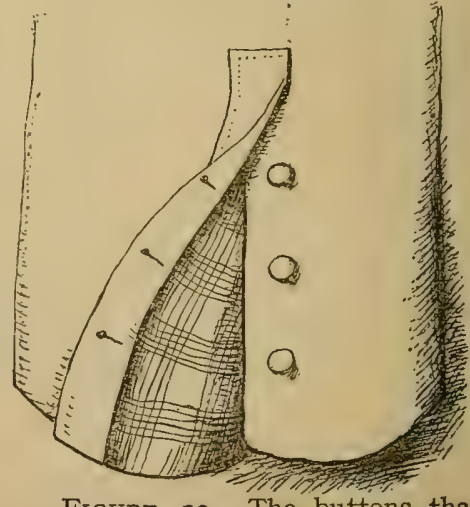

FIGURE 13.-The buttons that close the slit up the back of a ulster. 
tion with it there are two or three buttons and buttonholes, usually hidden, which allow of the opening being closed up. Here, then, we have buttons on the back of the coat still serving a useful purpose, and it is not at all difficult to trace the series of fastenings back to a much longer one, which in the seventeenth century was quite obvious. (See Figure I4.) Each button and buttonhole was placed in the middle of similar pieces of lace or embroidery, so that the sides of the coat were made to look symmetrical. The object in view was the keeping of the skirts of the coat together when the wearer was not on horseback. At the present day

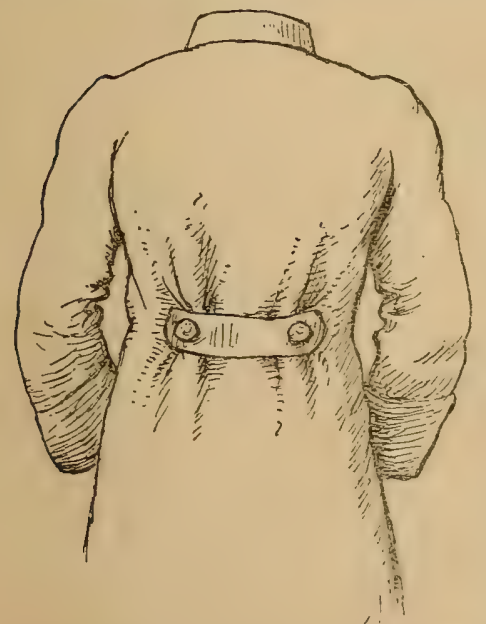

FIGURE I 5.-The tab and buttons on the back of a soldier's great coat make a temporary waist.

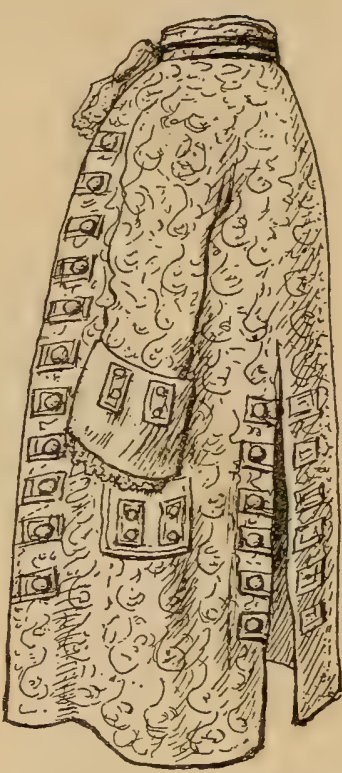

FIGURE I4.-A back view of a seventeenth-century coat showing the buttons and buttonholes.

the buttons have been duplicated and are on both sides of the coat, and they are still sewn to ornamental pieces in the uniform of the Grenadier Guards. The presence of the lower buttons on uniforms and coats is therefore explained. It might be assumed that the topmost button had also been doubled and raised above the slit, and that in this way we have obtained the two ornaments on the back of our coats. 
Before accepting such a solution of the problem, however, it may be well to see if the buttons may not have had another

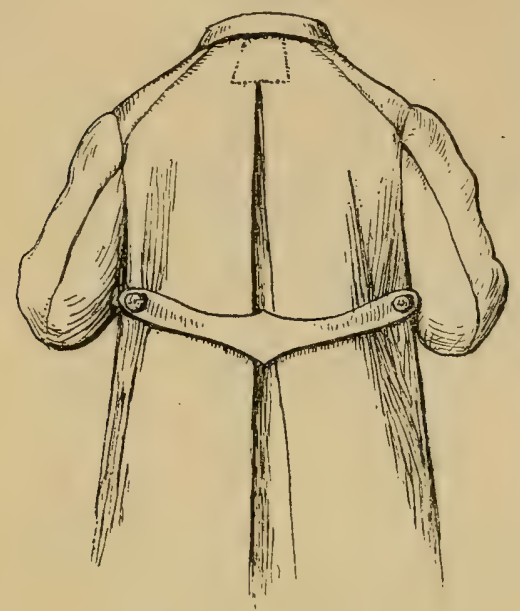

origin; and, on looking for some clue, we find that two folds take their rise from the point where the buttons are situated. These may be expected to throw some light upon the question. The folds are now permanent, but on a voluminous coat, such as still used by horse soldiers and tramcar drivers, they can be produced temporarily, and a waist obtained (see Figures 15 and $I 6$ ) by set-

FIGURE 16.-The buttons and tab on ting the two buttons further a tramway driver's coat.

one to the other. Sir George Darwin has expressed the opinion that the two buttons under consideration are the hindermost ones of the pairs that were once used to keep in place two small tabs at the sides of the coat, and so helped to produce a waist when required (see Figures I7 and I8), but in some drawings of coats (see Figure I8) the side tabs and their corresponding buttons are shown in addition to those on the back of the coat.

In the beginning, the buttons may have been used singly on the sides of the coat, for they are so wide apart as to be to all intents and purposes in that position, on the uniform

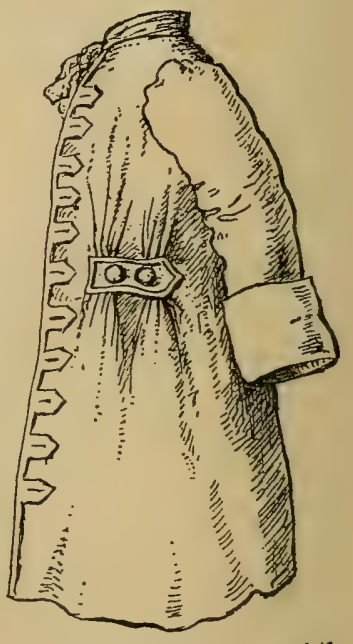

FIGURE $x_{7}$.-An eighteenth-century coat with side buttons and tab. 
overcoats of the London Electric Tramway drivers. (See Figure I6.) It is possible that they represent the topmost buttons of the lateral series still found on the overcoats of the members of the Corps of Commissionaires. In this case there are three buttons on each side, of which the middle one is used for fastening the sidepocket.

It is worth while to consider side-pockets, which in their turn are remnants of lateral openings which were made in coats at the end of the seventeenth and the beginning of the following century. The sword-handle conveniently protruded through the left-hand slit, which, like its fellow, ran

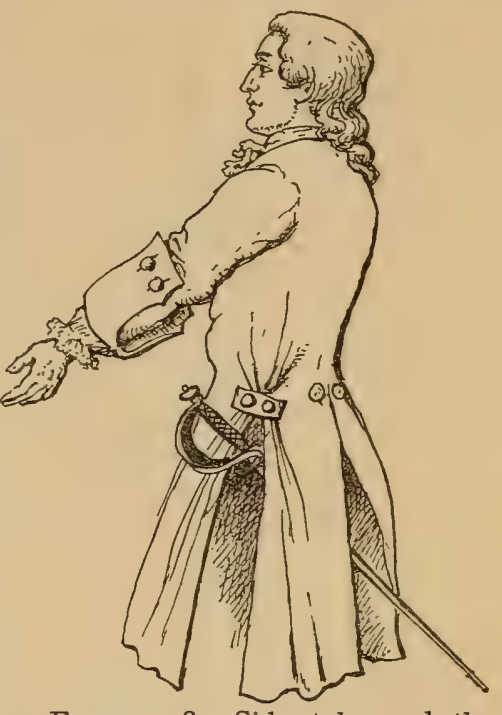

Figure I8.-Side tabs and the two buttons at the back as well (after Racinet).

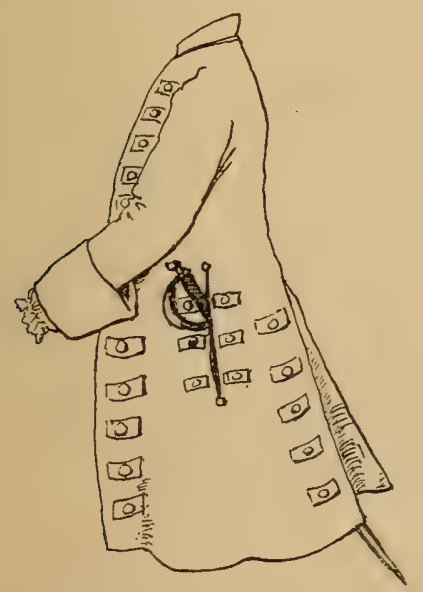

FIgURE I9.-A coat worn at the end of the seventeenthcentury (after H. Bonnart).

from the waist to the lower margin of the coat or stopped half-way. (See Figures $x 8$ and Ig.) In the latter case, the arrangement very much resembles the vertical pocket which has become common again of recent years. (See Figure 20.)

Occasionally a tab, such as that to which reference has been made, kept the parts of the coat together; but often there were buttons and buttonholes, at least at the upper end of the openings.

These survive in several cases, such as in the overcoat of the 
commissionaire, already mentioned, while the pocket is sometimes represented by a mere flap (see Figure 2I) ornamented

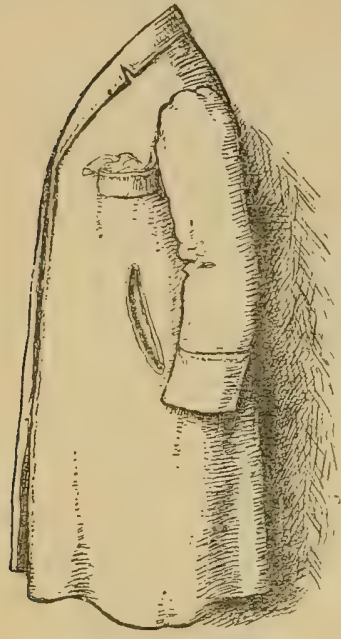

FIGURE 20.-A modern coat with side pockets. with buttons as on the livery of certain footmen.

Buttons on the skirt behind have in the meantime had a very intimate connection with the evolution of the "swallow-tail" coat (see Figure 24). They were used to fasten the corners of the ordinary riding-coat together, so that the linings should not be injured by the sweat of the horses. (See Figure 22.)

Mr. Deane Butcher tells me that he can remember this buttoning back being done in the case of his uncle, when the latter rode to market or to church; but in this case it was the two uppermost buttons which were again brought into use. At dances the coats were also subjected to similar treatment, and what at first was a temporary condition afterwards became a permanent one. It is obvious that the turned-back lining would often be of a different colour from the outside of the coat, and facings on old uniforms, and in that of the present dress of a lord-lieutenant (see Figure 23) are derived from the practice of fastening the corners of the coat together. In the "swallow-tail" the outer corners have been cut right away. (See Figure 24.)

The buttons, in the interesting cases

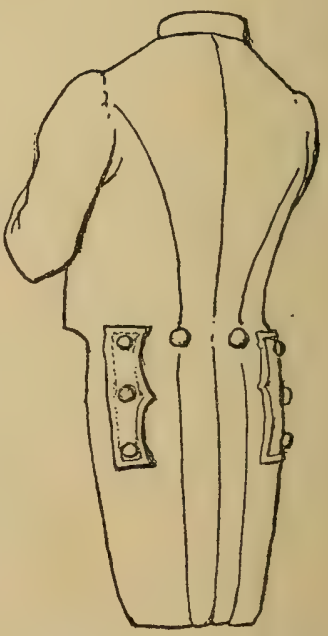

FIGURE 2I.-A footman's coat, modern, with vestigial pocket flaps. 
which we have described, have been allowed to remain as part and parcel of our costume on account of their decorative character, and in a great measure the same is true of those on coat cuffs (see Figure 25). In many cases there are proper buttonholes, and it is possible to undo the sleeve buttons; but occasionally we may notice that the arrangement has degenerated and the buttonholes are imitations, or only the buttons remain.

To find an explanation of this feature we shall have to go back again to the seventeenth century, when so much was expended upon coats that it became advisable to turn back the cuffs out of

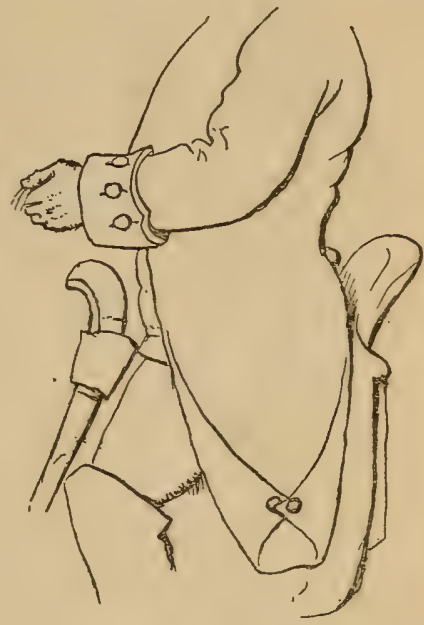

FIgURE 22.-Coat skirts buttoned back (after Hogarth). harm's way. To hold them in position, series of buttons and buttonholes were devised, and just as the turning

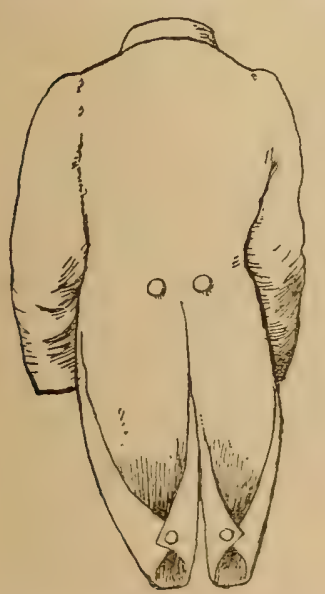

Figure 23.-A coat with the skirts buttoned ack and showing the ning.

back of the skirts was at first temporary and afterwards came to be done once and for all when the coat was made, so the turned-back cuff grew into a permanent institution. In Figure 26 the buttons are one above the other as in modern dress, but in the next two Figures (27 and 28) they are horizontal.

A survival of this arrangement can still be seen in the coat sleeves of the higher clergy. In ordinary dress, the turned-back edge of the cuff may now only be represented by a band of braid or a row of stitches; but in soldiers' uniforms, an ornamented cuff persists 
which represents in reality the lining of the sleeve. Again, the turned-back cuff is actually present in the clothes of

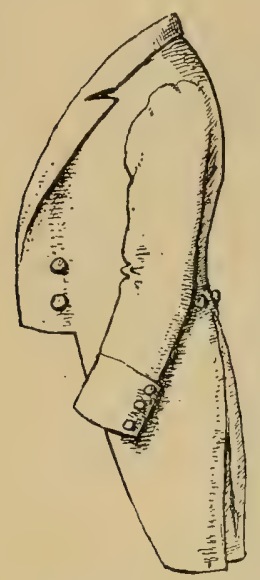

FIGURE 24.-A dress coat with skirts cut away. costermongers, and has been revived on overcoats to a considerable extent during the last few years. (See Figure 29.)

As a rule, too, the vertical pocket already described accompanies the turned-back cuff, as it did some centuries ago. (See Figure 20.)

It must not be forgotten that buttons have long been used on narrow sleeves. They are undone when the hand is to be pushed through the cuff, and afterwards fastened for the sake of warmth or to give a neat appearance. It is therefore possible that the ring of buttons is more properly a survival of the time when cuffs were turned back to preserve them, and that the vertical row is really of earlier origin. A uniform represented by Hogarth (Figure 30) shows both the row of buttons and the turned-back cuff, which seems to be quite independent of them.

In this instance we may have the degenerated turned-back cuff and one revived, shown together. Such a case, we need scarcely point out, could not occur in the case of an animal structure.

The adoption of buttons more or less - for ornament has long been practised. John Brandon, who died in the year I364, is shown on his brass (in the church of St. Mary, King's Lynn) with no less than forty buttons on the sleeves of his undervest, which has embroidered cuffs and is buttoned to the elbow (see Plate IV).

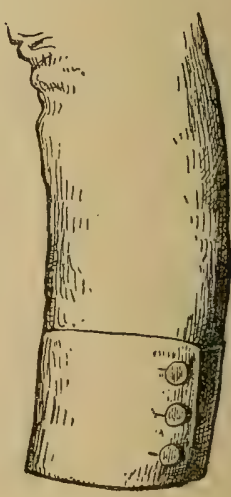

FIgURE 25. - A modern icoat cuff with buttons. 


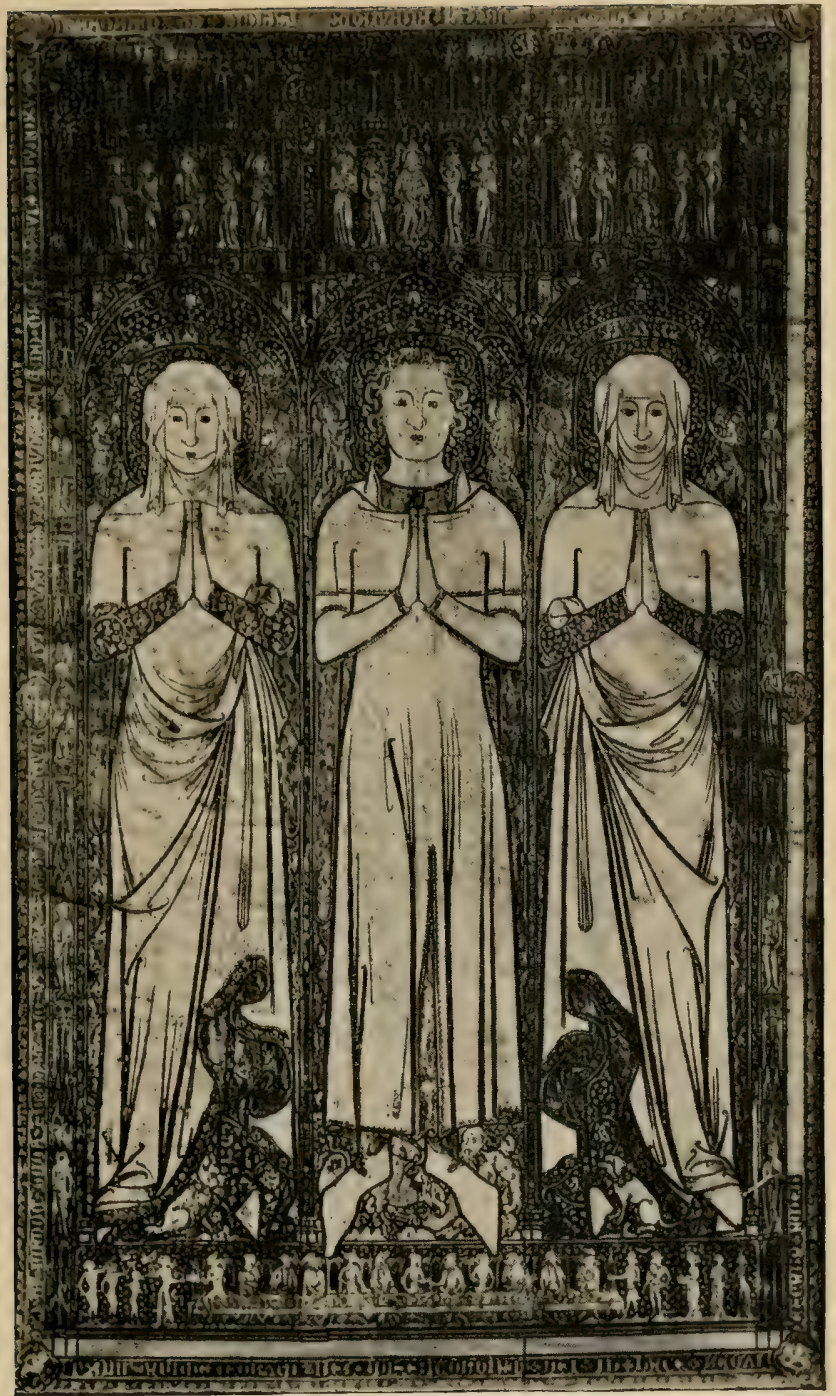

REPRODUCTION OF A BRASS TO JOHN BRANDON AND HIS TWO wives, in the Church of St. Mary, King's Lynn. Date 1364. ON THE MALE FIGURE A CONTINUOUS ROW OF BUTTONS RUNS FROM THE IVRIST TO THE ELBOW OF THE UNDER VEST. THE WOMEN WEAR THE WIMPLE AND THE GORGET OR THROATCLOTH. (See page 26.) 

We shall, however, have something more to say with regard to buttons from this and other points of view as we proceed.

An interesting case of superfluous buttons on the front of clothes is to be seen in the case of the short jackets of the postilions belonging to His Majesty the King. There is a useful row down the middle which closes the garment, and two ornamental rows which start from each shoulder and curve downwards towards the middle row. These are vestiges of buttons that were once of use, and to seek an explanation it might be well to study some uniforms of the past. We shall find that in the eighteenth century it was customary to button back the revers of the uniform coat, as in the case of

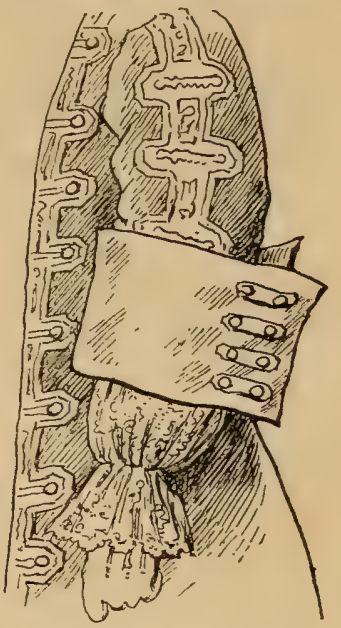

FIGURE . 26. - Turnedback cuff, end of seventeenth century (after Bonnart).

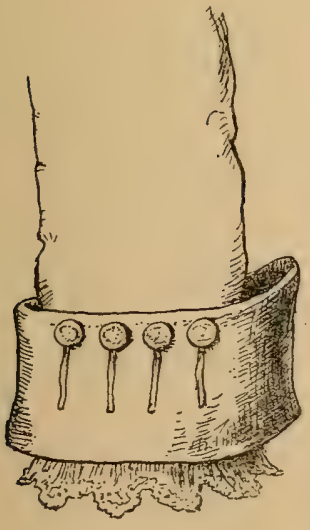

FIgure 27. - A coat sleeve (after Hogarth) with a horizontal row of buttons. the French coastguard officer of 1775 (see Figure 3I), or the English officer, say, of the goth Light Infantry of I794.

The replacement of hooks by buttons would give us a third row, as seen in the postilion's jacket. Fáshion afterwards decreed that the coats should be fastened again with hooks, but the two rows of buttons remained.

In the coat of the postilion there is no trace of the revers which showed the lining, and were consequently of a different colour from the rest of the coat. We find, however, in the peculiar uniform of the Lancers that 
there are the two side rows of buttons, to which is fastened a red front, or plastron. This appears to represent the two

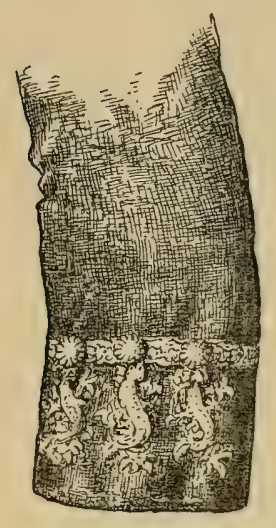

Figure 28.-Sleeve of a coat of the seventeenth century, reputed to have been worn by Charles I. revers combined. In the year I907 a number of ladies' dresses were to be seen in which the revers trimmed with a different material from the dress were buttoned back against the latter.

In some ceremonial dresses and uniforms there are cross stripes on the breast (see Figure 6I) which, it has been pointed out, represent series of buttonholes which have become hypertrophied, and are now exaggerated beyond recognition. The braid on the cuff of the London Scottish Volunteers seems also to represent buttonholes.

Such features as turned-back cuffs occur in women's clothes, and, as we

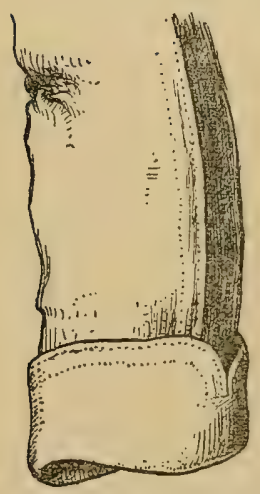

FigURE 29.-The turned-back cuff on an overcoat, modern. A similar one is seen on the ordinary coats of costermongers.

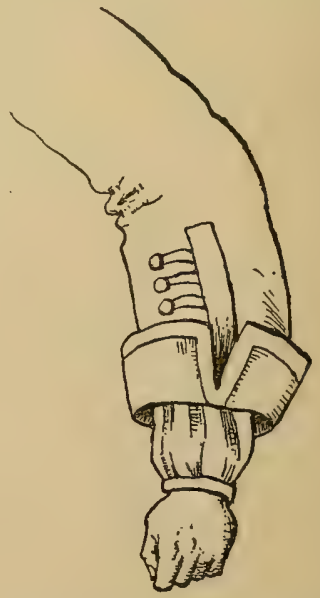

FIGURE 30--A sleeve with vertical buttons and a turnedback cuff as well (from a uniform, after Hogarth). 
have seen, the arrangement of buttons may be copied from masculine attire. In other cases buttons seem to appear which have, it would seem, no hereditary right to their position; but it may be well, before dismissing them, to see whether they have not a pedigree. We might cite the case of the buttons that at one time were sewn on to the frocks a little below the knee. They are often at the head of a plait, and it would be worth while to look into their history. Others on dresses at the present time (IgI2) seem to be merely ornaments.

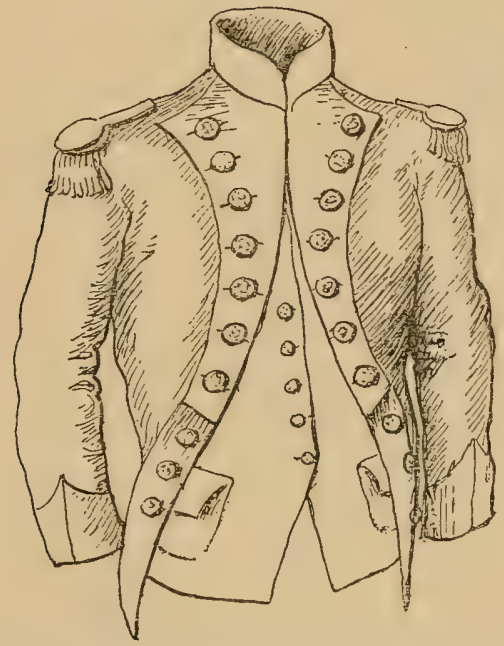

FIGURE 31.-The uniform of a coast-guard officer of $\mathbf{I} 775$ (after Racinet). 


\section{$\dot{V}$}

\section{COLLARS AND BANDS}

NICKS IN COAT-LAPELS-THE WHY AND WHEREFORE OF THE WHITE SHIRT FRONT

I ET us carry on our work of dissecting the clothes of a 1 modern man, and as we once more survey our subject, we may glance a little higher than heretofore, until our eyes rest upon the collar of his coat. This structure passes into the lapels, and at the point of junction there is a curious nick which is repeated in the waistcoat if this be similarly provided with a collar. (See Figure 32.)

There is always, a temptation to invent some interesting theory in order to explain the origin of vestiges, and a penny paper, which hardly boasts of scientific accuracy, not long ago informed its readers that the slit in the coat lapel is the outcome of a "unique and beautiful custom among the orthodox Jews," for in former days, when death visited a Jew's household, he cut the lapel of his coat. It was undoubtedly a custom of the Jews to rend their garments, but it does not, on the face of it, seem likely that the practice would have - influenced modern costume. It would appear, however, that the slit in the lapel has a much more prosaic origin, and owes its existence rather to a practical requirement than to a sentimental observance. When the collar of a coat is made to stand up, it is absolutely necessary that a piece should be cut out of the cloth, or the lapel will not lie down. In the 
exaggerated garment of which we give an illustration (see Figure 33) this need is most manifest ; but a moment's thought will show that the provision must be made, even if the collar be small. A trifling experiment will indicate that at the present day the cut is not usually made deep enough to allow of the collar being turned up without disturbing the lapels.

Another remarkable variation is to be found in the collars of some dress suits. A little point is left on the collar known to tailors as the "toothpick," which runs across the nick on to the

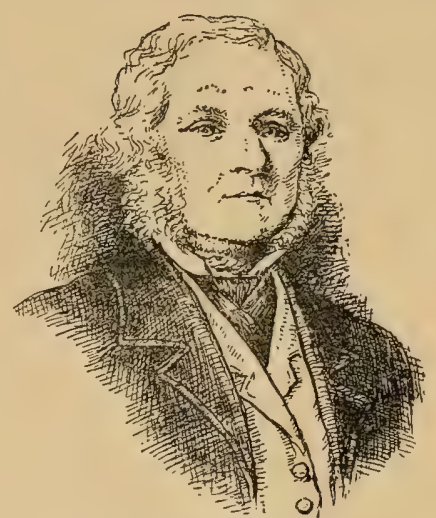

FIgURE 32.-The nicks in the coat and waistcoat. the lapel (see Figure 34). This structure is probably a survival of some particular kind of collar.

It might be pointed out here that the facings and collar that are of silk or velvet represent the lining of the coat which came

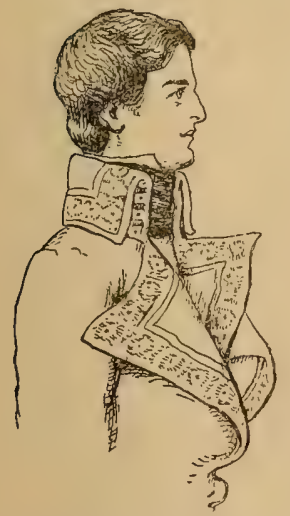

Figure 33.-A stage when the nick was useful (Lucien Bonaparte, after Paul Lncroix). into view when the collar was turned down and the lapels turned back. The case is quite similar to that of the cuffs on uniforms, and to be quite consistent, the whole coat should be lined with what is usually used now only as a kind of trimming.

It is but a short step from the features that we have been discussing to the linen collar and the shirt front. The cutting away of the outer garment to bring the shirt into view is a relic of the time when only those who were very well-todo could afford to wear linen, and they showed it, in order to indicate their 
social position, or at any rate their financial resources. At the same time, the women cut their dresses low so

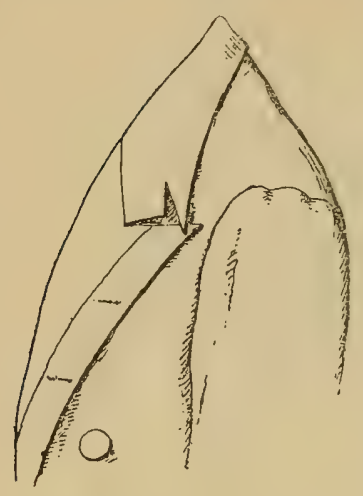

FIGURE 34. - The
"toothpick" on a dress coat.

as to show their underlinen; and not content with this, they further, at the end of the thirteenth century, slit their gowns from the armpits to the hips. The openings thus made were laced across, so that the linen garments beneath could easily be seen.

The white shirt has long survived, and in spite of its depreciated value has up to quite recently posed as a badge of respectability. Now at last there are signs that its sway is over, and that soon it will come to be only a garment of ceremony.

The linen collar of to-day is quite a small affair compared with some of its forerunners. An interesting relic is to be seen in the two little linen flaps which we call bands (see Figure 35). These are still worn by preachers in conjunction with the Geneva gown, by barristers, as well as by Blue-coat boys (see Figure 36), and we can easily trace their relationship to the collar. Until a few years ago the choristers at Jesus College, Cambridge, wore a peculiar collar which ended in two flaps much resembling bands, and the descent of this from the large structures which were called falling bands is not difficult to trace.

The portrait of Jan Steen, which we reproduce, shows bands which are less stiff and formal, but of ampler proportions. (See Figure 38).

Going a little further back, we find the collar that covered the shoulders,

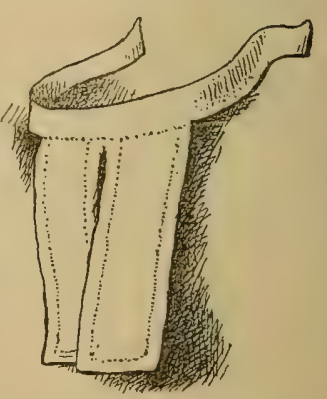

FIGURE $35 \cdot$-Modern bands. 
such as Milton wore, and which is shown in our picture of John Pym. (See Figure 39).

At this point we may pause to recall a simple article which

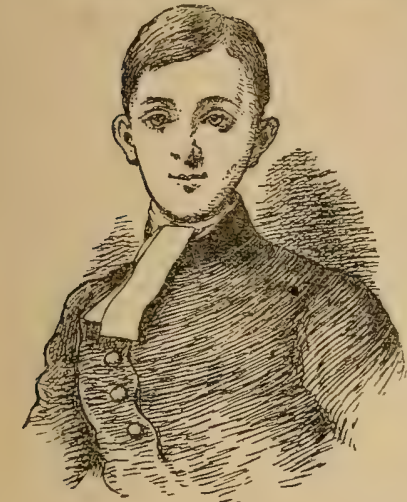

Figure 36.-A blue-coat boy's bands. is known as a bandbox, but which has been diverted from its original purpose of holding bands, and is now commonly used as a receptacle for hats. Though not itself part of dress, the bandbox furnishes an interesting instance of adaptation to circumstances. It was well suited to contain articles of dress other than those for which it was primarily intended, and hence it has survived in the struggle for existence. (See Figure 40.)

We must not, however, jump to the conclusion that bands are now only represented by vestiges, for they are still to be seen in their full glory on very small boys (see Figure 4I), and the writer recalls a lad of fourteen or so who had reached the dignity of trousers who wore the same kind of collar. As he also had a trencher, or in common parlance, a "mortar-board," it is possible that he was not an isolated survival, but a scholar on the foundation of some school. The large collars of the Eton boys may appropriately be mentioned here.

As linen collars are among the few articles of dress in regard to which the wearer is allowed

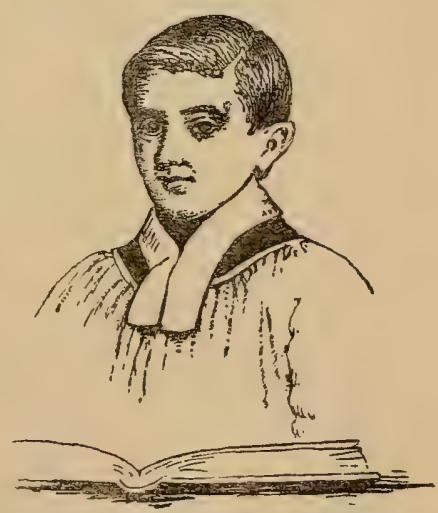

Figure 37.-A chorister of Jesus College, Cambridge, showing the collar worn until recently.

(From a photograph by the courtesy of Mr. H. A ustirs Wheatou.) 


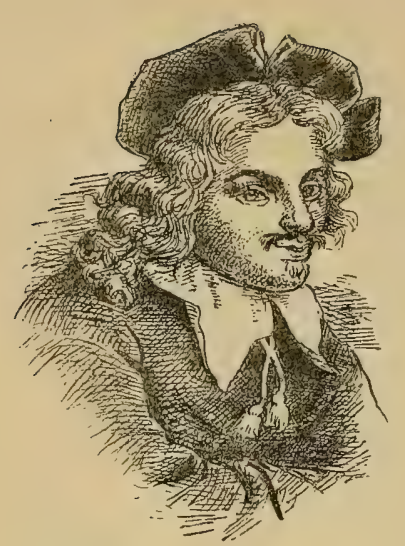

Figure $38 .-\mathrm{A}$ stage in the reduction of the bands. (A portrait of Jan Steen, from The Illustrated Magazine of Art.)

in a great measure to follow his own taste, it is not surprising that a great many forms have from time to time been invented. Quite a number are still to be seen here and there, while the development of the more fashionable shapes one from the other would, in itself, form a chapter in the Evolution of Dress. The clerical collar

may be singled out, as it fastens behind like the bands, though the reason for this is not at all obvious.

In recalling the great ruff and expanded collars of Queen Elizabeth's reign, one may be inclined to smile at the lengths to which a fad may be carried, and the curious, not to say monstrous,

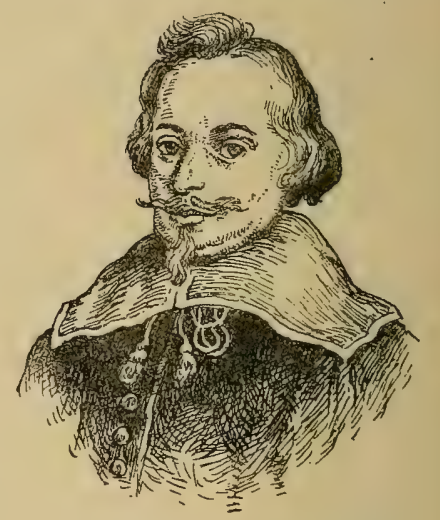

FIGURE 39--Full-sized bands.

(A portrait of John Pym from The Illustrated Magazine of $A v t$.)

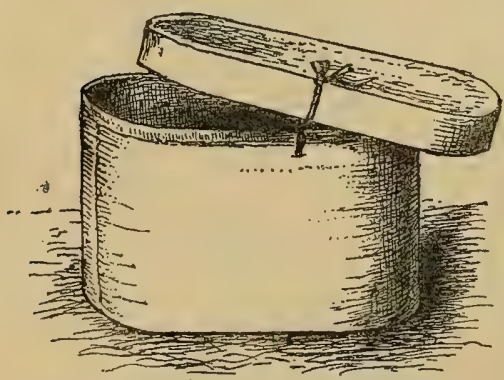

Figure 40.-A modern bandbox, now used for hats.

structures that are its culminations. These, like the huge creatures of bygone ages, die out, but differ in this respect that they sometimes revive for a time. For instance, only a few years have passed since the collars of ladies' mantles stood up round the back 
of their heads; but as the collars usually lacked the decoration and colour of the Elizabethan period, they appeared as if they were intended merely to keep the draught from the necks of their wearers, and they did not last long.

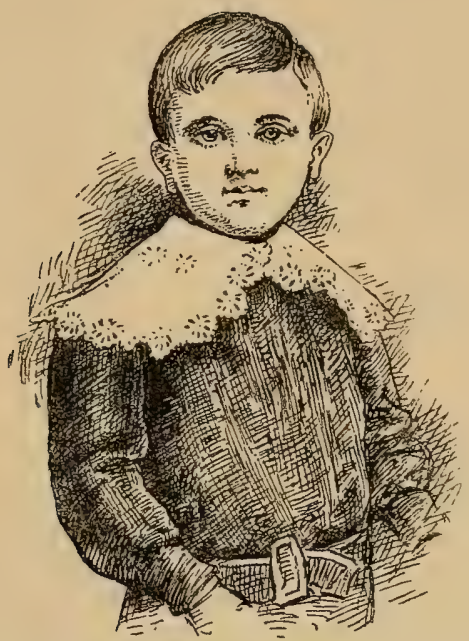

FIGURE $4 \mathrm{I}$.-Bands that survive at the present day. 


\section{VESTIGES IN THE HAT}

HOW HATS WERE EVOLVED-WHY PLUMES ARE ON THE LEFT SIDE-THE GROWTH OF THE BUSBY-HELMETS AND COCKED HATS.

THOSE who have written upon dress from an artistic point of view have recognised that costume and architecture are affected by the same influences. When we come to the hat, we find that its name is connected with that of a building of a primitive character, namely, a hut. Mr. Allan Poe Newcombe, an architect, some years ago pointed out the curious resemblance which has existed, and is still to be found in many countries, between headgear and habitations or other buildings. ${ }^{7}$ It may be that the cases which have been collected together are mere coincidences, though it must be allowed that they are both numerous and striking. It may be that the same taste, or lack of it, has given rise to the similarity of style, or in the beginning, the designer of the hat may have taken the hut as a model.

In the Hawaian Islands, long before the inhabitants troubled

- about clothes, they built themselves grass houses, and at the present time the characteristic Hawaïan hat is remarkably like the hut. The turbans of Eastern Church dignitaries are still of the same shape as those worn by the high priests among the Jews, and are remarkably like the characteristic dome which surmounts a mosque. (See Figure 42.) 
Looking about in other countries we shall find further instances that support Mr. Newcombe's contention; our illustration of a Siamese head-dress and building is a case in point. (See Figure 43.)

Again, going back into European history, we find that the high pointed spires of Gothic churches were co-temporaneous with the high horn-like head-dress known as the hernin (see Figure 44). It is claimed, moreover, that like results will be found after a comparison of other styles of architecture with the costume of the period in which they flourished.
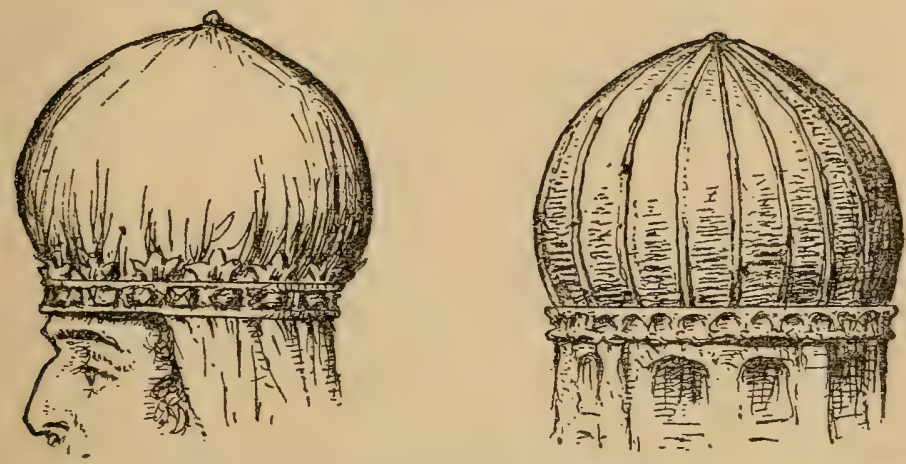

FIGURE 42.-The turban of a Jewish priest (after Kitto) compared with the dome of the Mosque of Omar.

Leaving this suggestive line of research, and coming to hats as we have them at the present day, we find that they offer several remarkable vestiges for our consideration. First of all there is the hat-band outside, which sometimes ends in two tails or streamers that hang from the back of the hat (see Figure 47). From the bow usually present, it is evident that the hat-band was tied, and the streamers represent the loose ends. As a matter of fact, primitively, a head-dress was made from a piece of cloth, round which a fillet was tied so that it fitted the head. In this connexion Figure 45 is most interesting. It represents the back view of the head of the Egyptian woman of the Sixth Dynasty, who is seen in Figure 76 , and 

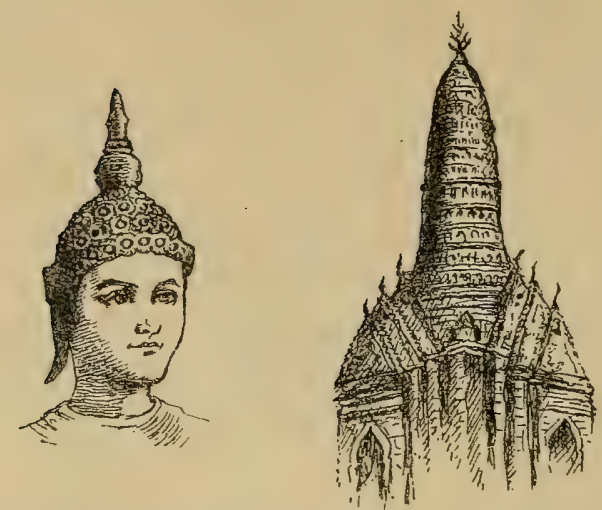

FIgURE 43.-A Siamese head-dress and a Pra Pang or Votive spire (after P. A. Thompson).

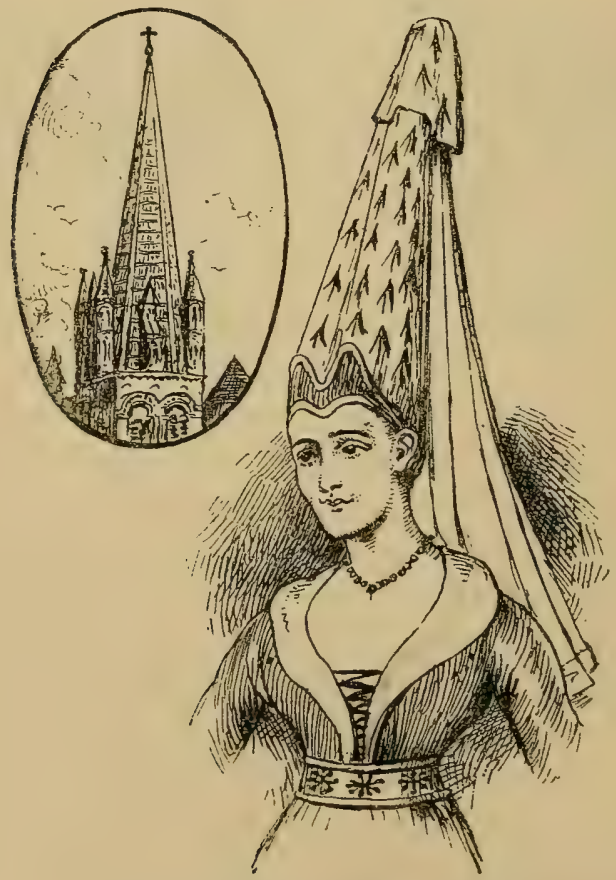

FIGURE 44.-A Gothic spire (St. Stephen's, Caen) compared with the hennin (the latter after Fairholt). 
shows a head-dress which is confined by a fillet that is tied at the back so as to make two tails.

The modern Arab fastens his kefiyeh with a twist of camel's hair without streamers, and the lady of the fourteenth century, shown in Figure 46 , has also an ordinary band.

The child's sailor hat and the Scotch cap are among the modern head coverings which retain the strings (Figure 48). A twelfthcentury head-dress shown in a manuscript (Figure 49) has a great similarity to the Scotch cap, as the band forms a kind of binding to the article in both cases, and there are streamers to both.

The strings or streamers are to

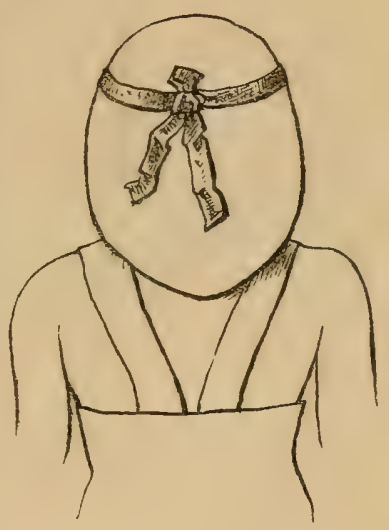

Figure 45.-Band with streamers fastening on the head-dress of an Egyptian woman. From a figure of the Sixth Dynasty, B.c. 3500.

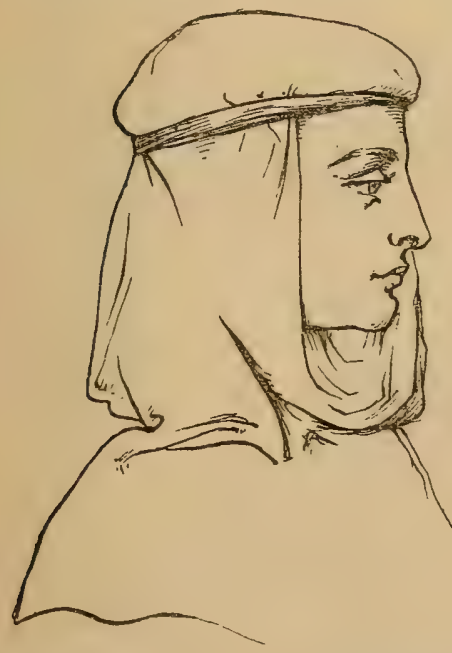

FIGURE 46,-A lady's head-dress confined with a fillet, fourteenth century (after Viollet le Duc).

be found in many other head coverings, including the mitres of bishops (see Figure 50). The particular mitre illustrated is that of the See of Durham, which is distinguished from others by being plumed.

An interesting suggestion as to the origin of the slit in the top of the mitre may be mentioned here. Head-dresses were used in very early times which were in the form of a fish's head, and it has been thought that the slit in the mitre, 
so distinctly shown in chess-men, represents the fish's mouth.*

On looking at the inside of a modern hat, a little bow of silk

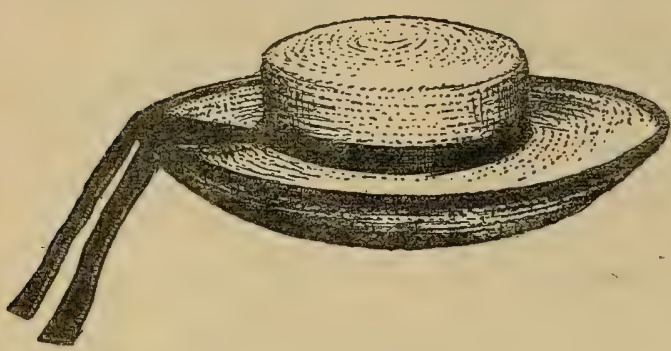

FIGURE 47.-A sailor hat with band and streamers. ribbon will usually be found at the back where the two edges of the leather lining meet. Here, again, is a vestige. (See Figure 5I.)

In some hats the ribbon does not simply make the bow, but it is threaded through a greater or less number of holes in the leather, though now fulfilling no useful purpose. (See Figure 52.)

In a hunting hat, however (see Figure 53), the lacing is continuous round the hat, and the lining can be made to fit the wearer. It helps to form a buffer, should the huntsman unfortunately fall on his head, and it is claimed that many lives have been saved by this small detail.

It may be gathered from the description that in times when hats could not easily be got to fit their wearers, the lacing inside

- would be most useful, as it ensured that the size could be adjusted.

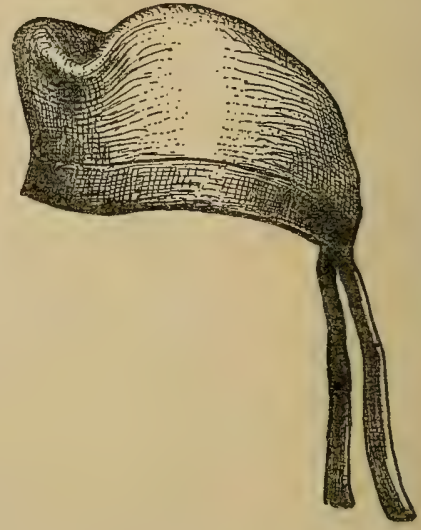

Figure 48.-A modern' Scotch cap with streamers.

* A correspondent, Mr. W. Morrison, has suggested that the mitre is an Egyptian crown. Alexandria was the University town of the early Christian Church. The Patriarch, like other clerics, wished to arrogate temporal power, and it is probable that he would wear an imitation of the crown. 
It is possible also that in the lacing we have a means by which a hat was originally shaped, and that the lace is really a hat band threaded through the material of the head-dress instead of being tied round outside. The first diagram on page 43 shows a flat piece of leather cut into a circular form; the next shows it perforated and a lace put through the openings; the third indicates how by tightening the string a crown could be made to the hat.

In time, when the crown was made in different ways, it would be easy to transfer the lacing to the lining as seen already in the hunting hat (Figure 53).

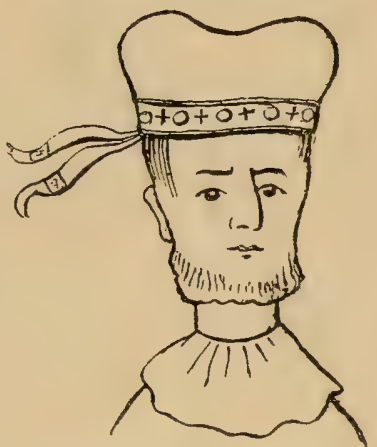

FIGURE 49.-A twelfthcentury head-dress with streamers from a MS. (after Viollet le Duc).

It is interesting to note that a small bow is also found inside ladies' hats, and often used as a place on which to put the name of the maker. (See Figure 58.)

Sir George Darwin ${ }^{8}$ has shown why plumes are, and used to be, on the left side of a hat only. In the days when the feathers were particularly long there was also plenty of fighting, and it only needs the attention to be drawn to the point to make one

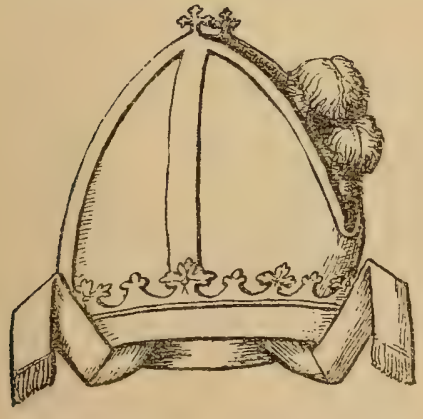

Figure 50.-A mitre of the See of Durham showing the strings (after Millington). realize that, if the plume had been on the right side, it might often have got in the way of a sword and thereby caused the overthrow or even death of its wearer. At the present day in the army (see Figure 59), the plumes will be found on the left side as in the days of cavaliers.

Sir George Darwin ${ }^{8}$ has also traced the origin of the busby, 
and has shown that the little red flap that hangs on the left side as a useless appendage is really the original cap. Busbies

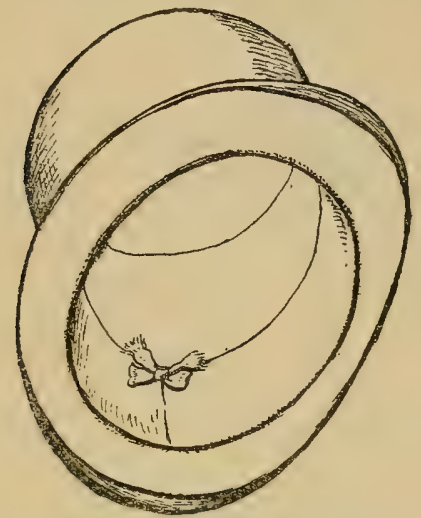

FIGURE 51.-Small vestigial bow of ribbon in a modern hat.

were the special attributes of the Hussars, who were originally Hungarian soldiers. It is the peasant's cap of Hungary that is the forerunner of the military head-dress which we are considering, and it consisted of a red cap of cloth with a band of fur round the edge. As time went on, the fur on the cap, which was adopted in the end by various regiments, became wider and wider, and the original red cap got smaller and smaller until the form of the modern busby was reached. In some cases even the flap already mentioned has gone, though the fact that the top of the busby is made of cloth instead of fur, still points to its origin. (See Figures 6o and 6r.)

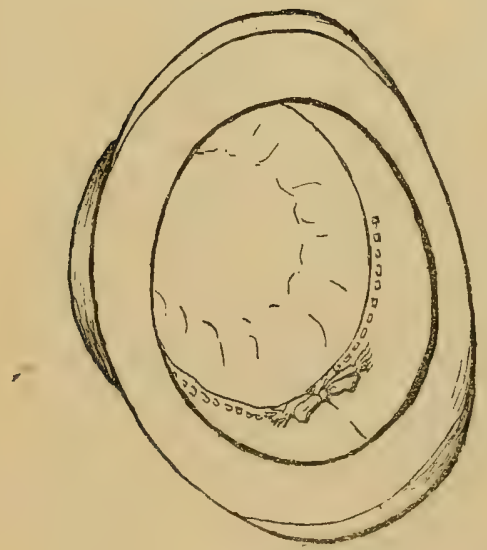

FIGURE 52.-A hat with the remains of lacing.

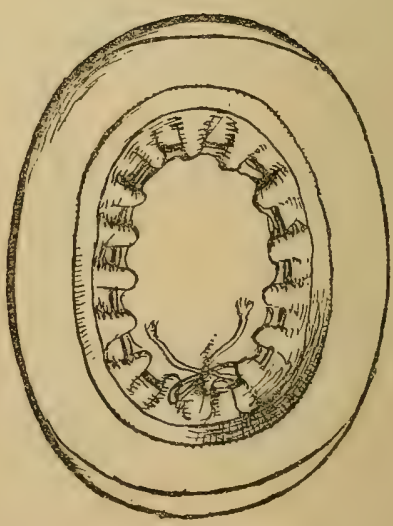

FIGURe 53.-A hunting hat with complete lacing inside. 


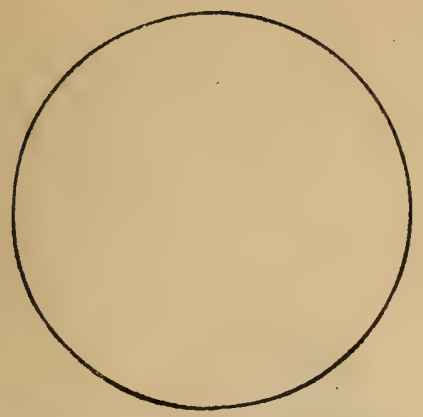

FIGURE 54.-A disc of leather.

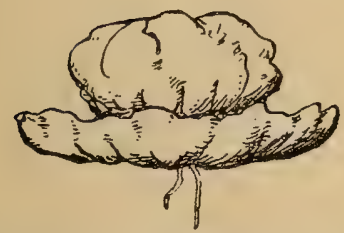

FIGURE 56.-The lace tightened to form a crown.

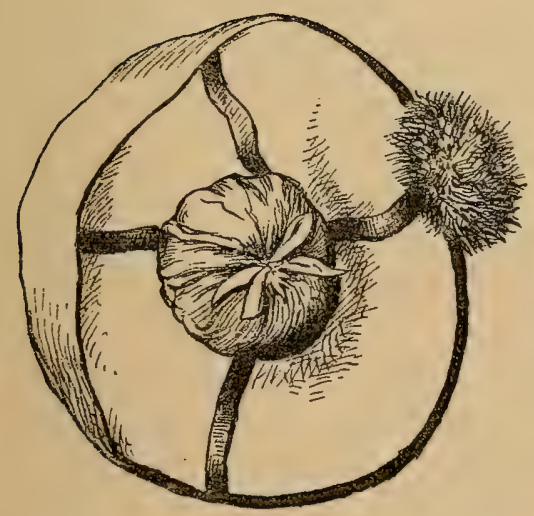

Figure 58.-A bow fastened to the lining of a lady's hat.

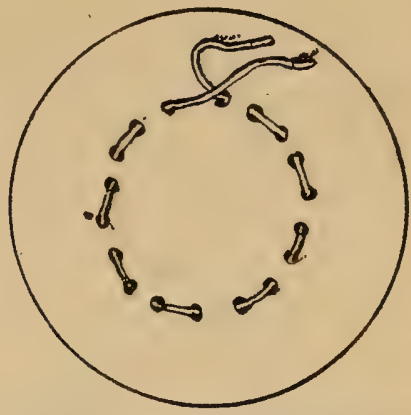

FIGURE 55.-The disc perforated and the lace inserted.

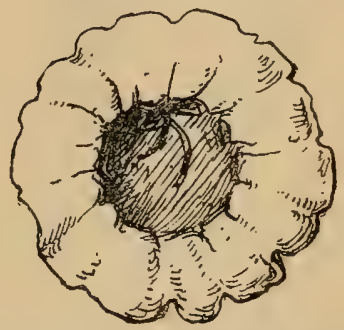

FIGURE 57.-The ends of the lace tied as a bow inside.

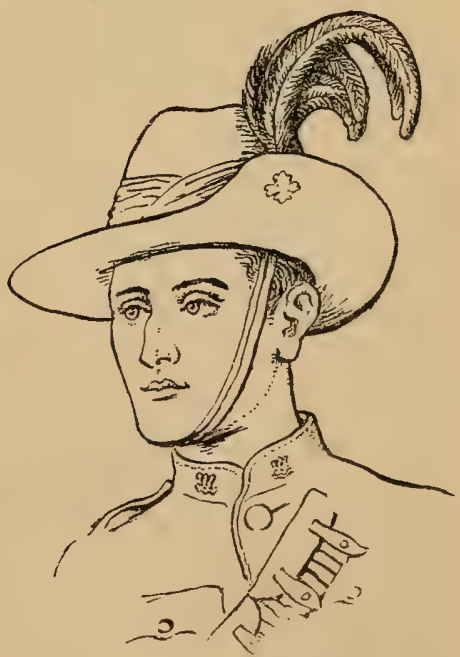

Figure 59.-Plumes on the left side. 
Though we are not discussing armour at the moment, we may say while speaking of military head-dresses that metal helmets are still in use in a few regiments. The helmet also of the fireman deserves attention, as it is practically of the same type as that worn by the ancient Greeks. (See Figure 62.)

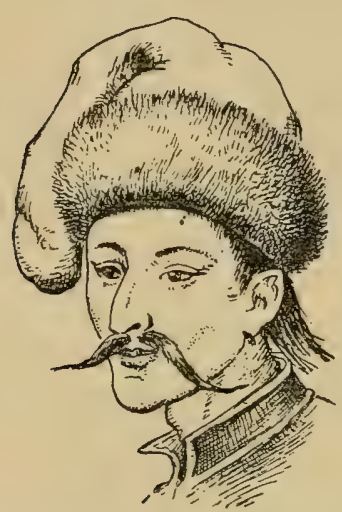

Figure 60.-The red Hungarian cap, which was the forerunner of the busby.

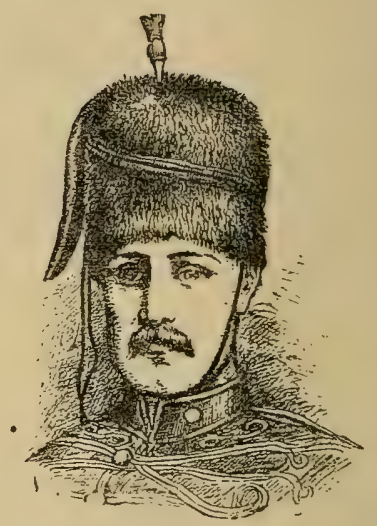

FIgURe 6I.-A busby (of the Honourable Artillery Company) in which the cap is a vestige only.

The cocked hat should also claim our attention, and it gives us another instance of temporary alterations which have ultimately become permanent. The picture of Hudibras (see Figure 63) shows an early stage in the history of cocking. The strings which connect the brim of a bishop's tall hat to the crown are evidently connected with this practice. In the modern cocked hat more of the right side is turned up than of the left. A little careful examination will render its development from the broad-brimmed hat easily understood,

- while the representatives of the hat-band and the details of the cocking will be soon discovered.

The cock of the hat formed a convenient spot in which to fix an ornament, and the name cockade has come to be applied to such an addition, borne on the hat, as a mark to distinguish the wearer. 
The part which cockades have played in history is considerable, but as they are now chiefly associated with the liveries of men-servants they will be dealt with later on in the book. Before, however, we leave, for the present, the subject of head coverings, we ought to mention that a piece of woven material as primitively used without even a restraining band, still survives in the shape of the small shawl which north-country girls and women very generally wear over their heads. The head-dress of the nun (see Figure I3I) is another case in point, and recalls that in vogue in Tudor times, while the sun-bonnet of the barge women, though more highly developed, still consists to a considerable extent of simple drapery.

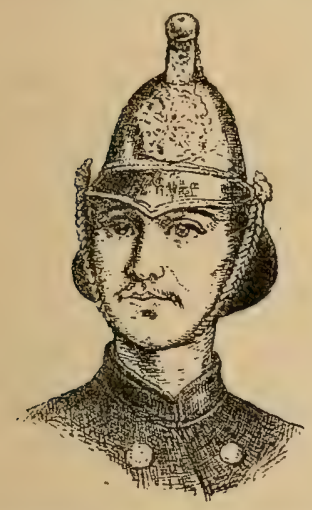

FIGURE 62.-A fireman's helmet (of the ancient Greek type).

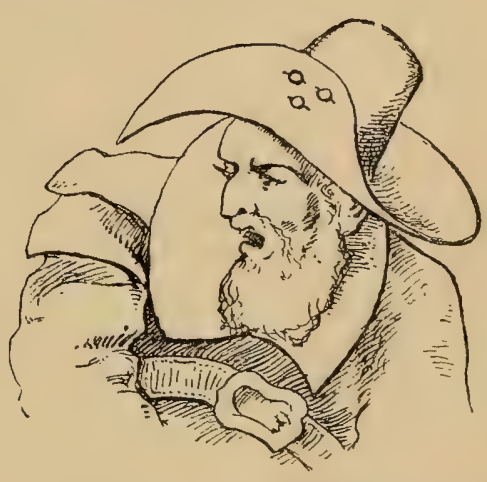

FIGURE 63.-A temporary " cock" (Hudibras after Hogarth). 


\section{VII}

\section{SHOES AND STOCKINGS}

EARLY FOOT-GEAR-THE ORIGIN OF THE CLOCK-A MODERN IMITATION OF TATTOOING-GAILY COLOURED GARTERS

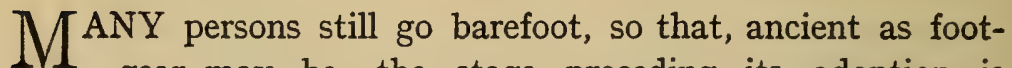
gear may be, the stage preceding its adoption is even now represented. Moreover, sandals, which are very primitive, have been much in use of recent years, and have especially been worn by children.

If we turn to ordinary boots and shoes we shall not find many obvious points about them which lead up to their history. Still we shall see in the case of a large number that in places where one piece of leather laps over another, it is perforated with rows of holes which form a kind of simple ornamentation. (See Figure 64.)

The perforations do not go through the boot or shoe, and in a Roman example in the British Museum, which is much more highly decorated, there are two thicknesses of leather, of which the outer one only is pierced. (See Figure 65.)

In many cases, however, the Roman shoe was truly of open work. It consisted of but one thickness of leather, and from this large pieces were cut out so as to make a kind of lattice. Several examples of this kind of shoe are exhibited at the British Museum, and we give an illustration of one of these, which is in a very fair state of preservation. (See Figure 66.) 
It seems very probable that the ornamentation on our modern shoes is a survival of the open work which was in favour with the Romans, especially as even then the apertures did not always expose the foot. In pre-Roman times in this country there were perforations in some of the shoes which were useful rather than ornamental, and one type (of which a specimen figured by Fairholt is preserved by the Royal Irish

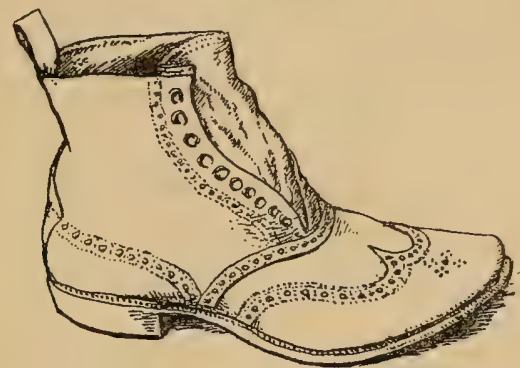

FIGURE 64.-A modern boot decorated with perforations made in the leather.

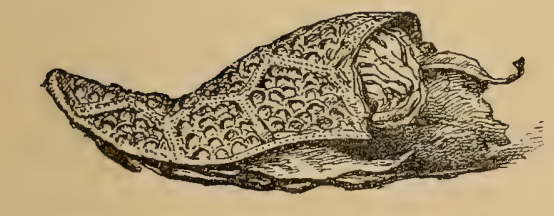

FIGURE 65.-An ornamented Roman shoe of two thicknesses.

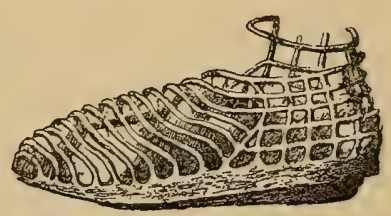

FIGURE 66.-A Roman shoe of open-work leather.

Academy) has survived until recently, if it is not to be found to-day, in Scotland and Ireland. This shoe was made of raw hide (see Figure 67), and the holes, it is said, were intended to allow the water to pass through when the wearer was crossing morasses. An examination of the figure will, however, show that the holes are really slits, and it would appear that, however useful they may have proved in the way described, they were originally made for quite a different reason.

The most primitive kind of shoe would doubtless be a piece of hide placed under the foot and brought up over the toes and 
round the heel. It would make a rather unprepossessing bundle, and there would be awkward puckers where the hide was gathered up. If the superfluous material at the toe were cut away, we should have a slit in every case where there had previously been a fold. This state of affairs is exactly what is to be seen in the Irish shoe, where the strips of leather that are left are held in place by a thong. In an ingenious way, apparently with the help of the same lace, the difficulty of securing

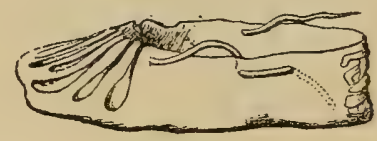

FIGURE 67 -A hide shoe of pre-Roman type from Ireland (after Fairholt).

a fit at the heel has also been got over. The result is a very neat shoe indeed, though in reality it is only the original piece of hide.

One of the most perfect instances of vestiges, as Sir George Darwin points out, is afforded by top boots. In their original form, still to be seen in our streets on sewer men, the boots were made to come above the knee, but fashion decreed that the top should be turned back (See Figure 68), and so it came about that the inside became visible, as did also the tags, with the help of which the boots were pulled on. When the outside of the boots was blacked it would form a distinct contrast to the inside, which remained brown, and in modern top boots the difference in colour has been in many cases greatly accentuated. Indeed, the upper parts are made of different leather, and, as ordinary coat cuffs are now incapable of being turned down, the tops of the boots are immovable and cannot be turned up. It is curious, however, that the tags at the sides are still represented and sewn to the boot so as to be quite useless, while new tags placed inside the boot now do their duty. (See Figure 69.) 
Socks and stockings are, at the present time, the most asual coverings for the lower parts of the legs, and there is at least one vestige which remains in their structure that has an interest for us. Before we consider this, however, we may look at another means of protecting the lower extremities which tells of more primitive conditions. The leg bandages so commonly worn by our regular soldiers and territorials are the case in point. (See Figure 7o.) These appear to have been immediately derived from the Indian Army, and their name"puttees"-is evidence of this; but such an arrangement is very widespread, and was that generally adopted in this country in Anglo-Saxon times. Our

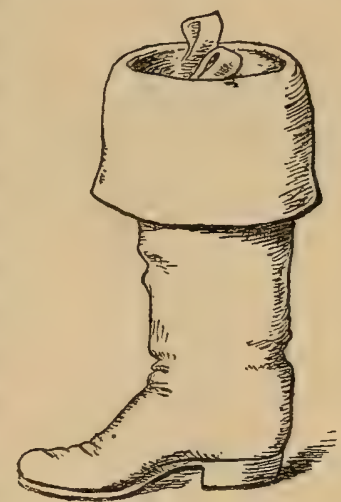

FIGURE 68.-The old type of top boot with the upper part temporarily turned down. illustration is taken from an illuminated manuscript prepared for St. Aethelwold for use at Winchester, which was completed between the years 963 and 964 A.D. Bandaged stockings are common on representations of Anglo-Saxons,

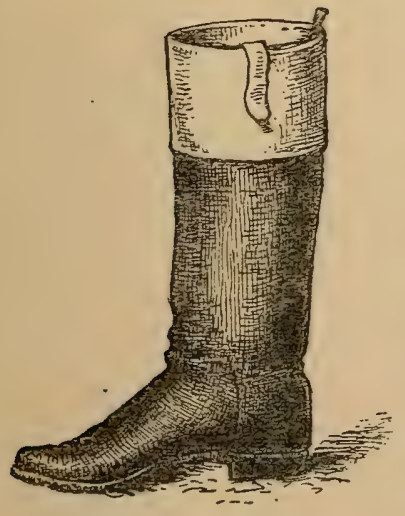

Frgure 69.-A modern top boot in which the upper part can no longer be turned up. but according to Fairholt the example given shows them to greater advantage than does any other known. The figure in question is dressed in royal costume, and the bandages, which are of gold, are fastened just below the knee with a knot from which hang tassels. (See Figure 7I.)

It has been thought that leg bandages were originally derived from the haybands which peasants wrap round their legs, and the writer has seen it stated that ostlers in this 
country still perpetuate the Anglo-Saxon fashion, though he has never met with an actudl instance. The pfiferari who

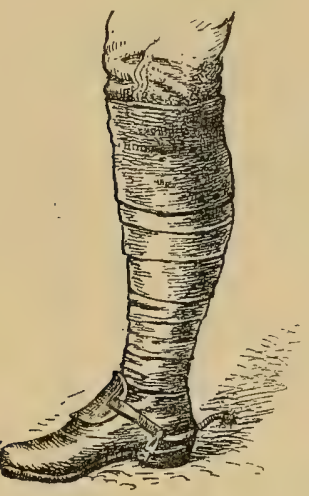

FIGURE 70.-Puttees. some years ago used to play on bagpipes and other primitive instruments in our streets; wore leg bandages or loose linen stockings, and these were crossgartered with bands which held in place a simple sandal made of a piece of leather.

The vestige in modern stockings to which allusion has been made is very often present, and takes the form of the ornament which we know as a " clock." The name signifies a gusset, and in modern socks and so on, which are woven or knitted all in one piece, no such arrangement is to be found. Stockings, however, like those at first worn by Queen Elizabeth, and used at least by American settlers until the year I675, were made up from pieces of cloth. In these there would be seams down the sides, and it is possible that where the ornamental lines meet in Figure 72 there may have been a gusset. In any case, it is evident that the intention of the clock was to hide the side seams.

Of recent years, when ladies have most sensibly adopted short skirts, the clock has developed into a series of embroidered patterns which cover the front of the foot and ankle. The parentage of these is quite evident from the shape, which is shown in Figure 73 .

This ornamentation has been carried still further, though it is not produced in the same way. The patterns, instead

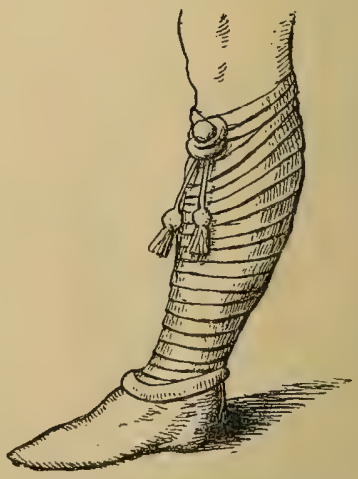

FIGURE 71.-Leg bandages of a royal personage at the end of the tenth century (after Fairholt.) 
of being ernbroidered, are the result of perforations, or, in more technical language, "open-work," and the background which shows up the design is no longer the material of the stockings, but the skin of their fair wearers. (See Figure 74.)

In many cases the stockings are dark in colour, and the effect of tattooing is produced without the preliminary pain and inconvenience. We have here an instance of the way in which the specially human instinct of decorating the body persists, and at the same time a development of the fashion for display-

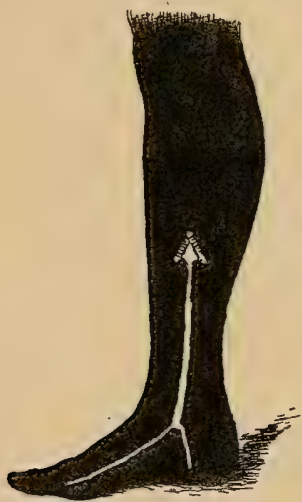

FIGURE 72.-A stocking with clocks.

ing, in the daytime under a thin veil of gauze or lace, the necks and arms which since the time of our grandmothers have only been allowed to appear uncovered in the evening.

Leather stockings were once worn, for example, by William Penn, and they and the leggings of to-day may be a direct survival from the time when our ancestors, though still wearing skins, had learnt to dress them. Leggings, as such, are possibly connected more closely with the protection of man against man than with that of man against the weather, and in that case their history is bound up with that of armour. Gaiters, under the name of spatter-dashes, were originally part of a soldier's uniform. To-day, when worn by civilians in ordinary dress, they are quite short, and go by the contracted name of 
"spats." Pedestrians still wear the full-sized gaiters in conjunction with knickerbockers, and white gaiters are a feature of Highland regiments.

Long Florentine hose, which practically took the place of trousers and stockings together, are now represented by what are called " tights," and are to be seen in the dress of acrobats. We shall allude to these again.

Garters when visible on men's legs become very ornamental, and one in use now, merely as a decoration, gave its name to

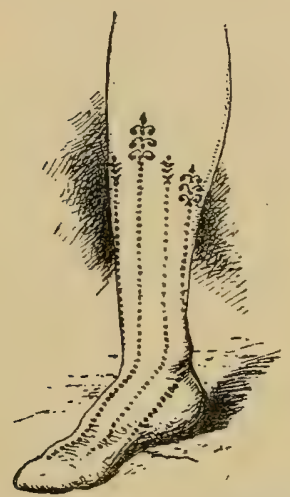

FIGURE 73.-An embroidered siocking showing the further evolution of the clock (date I900).

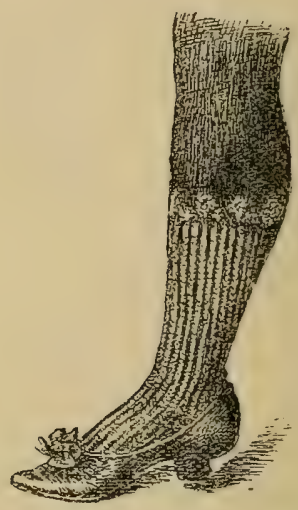

FinURE 74,-An open-work stocking of 1905. By no means an elaborate one.

the celebrated Order of Knighthood, among the insignia of which it is still to be found. At the present day garters are hidden, and there is a tendency for them to be replaced by more comfortable straps or " suspenders," but those which ladies wear still retain their gaudy character. 'In this connection an interesting ceremony may be mentioned, which is carried out in Haute-Vienne on the day of St. Eutropius. All the girls of the neighbourhood troop to the church dedicated to the saint at St. Junien-les-Gombes, and each damsel hangs her left garter on the cross hard by, which becomes so smothered with garters of different colours that when seen from a short distance it looks as if it were covered with flowers. 


\section{VIII}

\section{PETTICOATS AND TROUSERS}

THE BELTED PLAID AND KILT-EARLY SKIRTS-THE ANTIQUITY OF TROUSERS-TROUSER STRIPES

$W^{\text {E were at some pains to trace the evolution of the coat }}$ from the shawl, and it is possible also to show that the petticoat, and through this even trousers, have equal claims to the same ancestry.

The plaid as we saw it in Chapter III. is only a shawl, and at one time in Scotland it was used as a covering for practically the whole of the person. It was ingeniously disposed, and part of it was fastened by a belt round the waist so as to form a kind of kilt or petticoat. Hence arose the name of belted plaid It seems to have needed a considerable amount of practice to put on this garment properly, and the method customarily adopted by the wearer was to spread the plaid on the ground and, after duly arranging it in its proper folds, to lie down upon it and fix it with the belt. Some races seem to have recognized very much earlier that it would be more convenient to separate the kilt from the upper garment. In fact, if we examine the woven garments which the Danish chieftain wore under his deer-skin cloak, at a time before the use of iron had spread to Western Europe, we find that round his loins he had a small shawl held in place by a girdle. (See Figure 75.)

The next stage in the evolution of the petticoat would be characterized by the permanent joining of the edges of the 
cloth, so that a garment would be formed which resembled the lower part of the tubular tunic which played its part in the evolution of the shirt or coat. Such a state of affairs

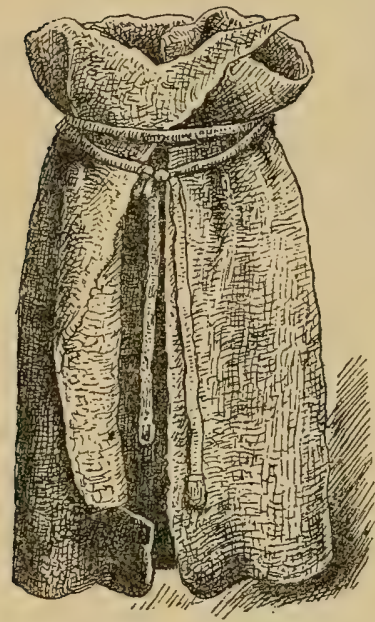

FIGURE 75.-A shawl used as a kilt by a chieftain of Denmark in the bronze stage of culture (after Worsaae).

is to be seen in the simple skirt of the Danish chieftainess whose bodice we have already described. (See page I4.) Here the petticoat was not shaped in any way at the top, but was gathered in round the waist and fastened, as in the case of the man, with a girdle.

In a warm climate it would be easy to dispense with a covering for the upper part of the body, and one of the simplest dresses imaginable was adopted in ancient Egypt. This costume is to be seen on the figure of a woman belonging to the Sixth Dynasty (3500 B.C.), which we have already mentioned when tracing the development of the hatband and ribbons. (See Figure 45.) In this instance there is a simple tight-fitting skirt reaching to the waist or a little above it, which is supported by two straps passing between the bare breasts and over the otherwise naked shoulders. (See Figure 76.)

It seems certain, as in the original carving the woman is shown with a burden on her head and in the act of driving a calf before her, that she is a representative of the peasant class. In the Korea at the present day, women of the lower orders, although they adopt a jacket which covers their arms and shoulders, wear so short an one that as there is no garment beneath it leaves their breasts quite bare. (See Figure 77.) Such an arrangement would obviously facilitate the nursing of children, and this fact has been advanced as the reason for 
its adoption. Still it may be merely a fashion such as some women, at the other end of the social scale, once adopted in our non-tropical country. In the time of James I of England, the noble ladies, while they wore an exaggerated ruff round their necks, nevertheless had their dresses cut away from just below it almost to their waists.

The short kilt now worn in Scotland represents the lower part of the belted plaid : it is in fact a petticoat and specially interesting, seeing that it is a survival of this type as a man's garment. Of the origin of the sporran which is worn in front of the kilt, little seems to be known, though it recalls to mind the time when men were clothed in skins; it forms a pouch as well as an ornament, and possibly also may have been useful as a protection. (See Figure 78.)

Having once derived the petticoat, however, from the ancestral shawl, it is a very simple matter to proceed, and evolve a pair of trousers. As a matter of fact, the Eastern women, when they fasten their petticoats between their ankles for convenience in walking, demonstrate the first stage in the production of bifurcated garments.

A single row of stitches will give rise to a kind of divided skirt, while two seams and a single cut made between, and parallel, to them, will produce a pair of trousers.

It would be strange if so simple a process, which under many conditions results in such a great improvement, had not been put into practice in very

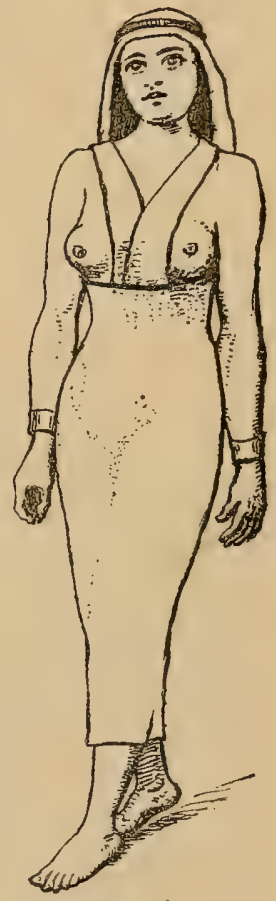

FIGURE 76.-A simple dress in the form of a petticoat from an Egyptian figure of the Sixth Dynasty (3500 B.c.), from the Myers collection at Eton College. 
early times, and trousers, although they seem to typify the ugliness of modern costume, are in reality surrounded by a halo of antiquity. It is only right, however, to point out that these tubular garments were in olden days not associated with the highest civilization. The Romans, for instance, did not wear trousers, though the nations whom they were pleased to call barbarians did. Some of the enemies of Rome are shown on Trajan's column wearing nether garments of the kind most familiar to us, FIGURE77-A Korean servant (after Hough).

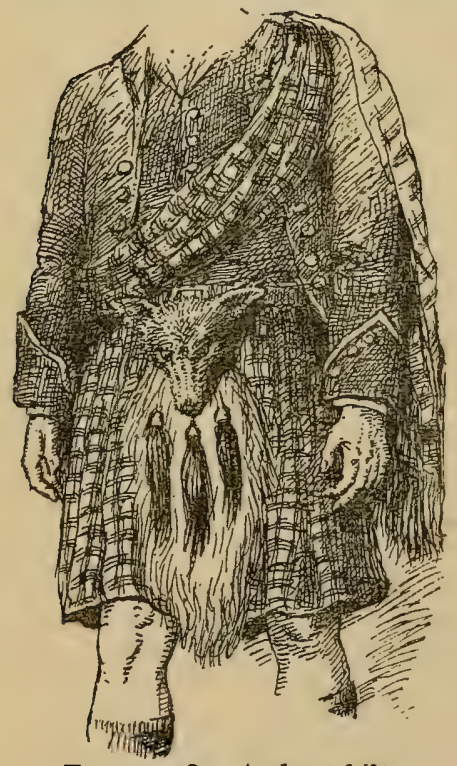

FIGURE 78.-A short kilt.

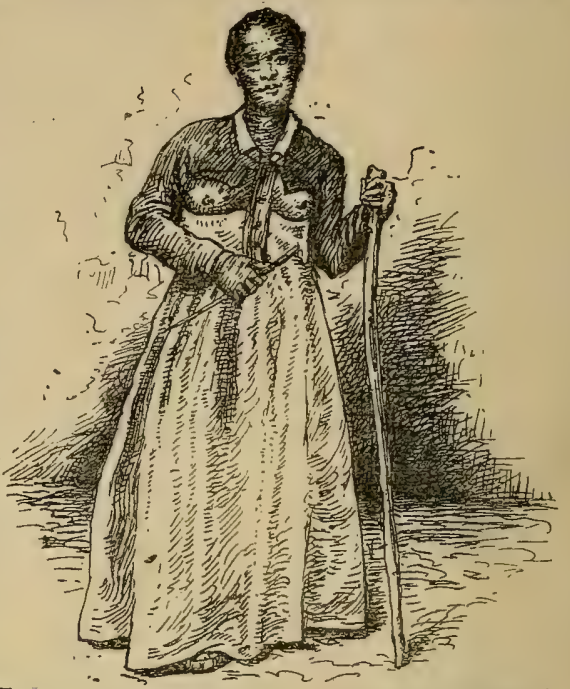

and our illustration is taken from the representation of a barbarian soldier carved on an ivory diptych of St. Paul. (See Figure 79.)

The kilt is sometimes called the garb of old Gaul, but on province of the latter owes its name-Gallia Braccata-to the custom among its inhabitants of wearing braccæ or breeches. In our own country trousers were in vogue before the advent of the Roman conquerors, and though for a time the dress of the invaders was adopted by those who followed 



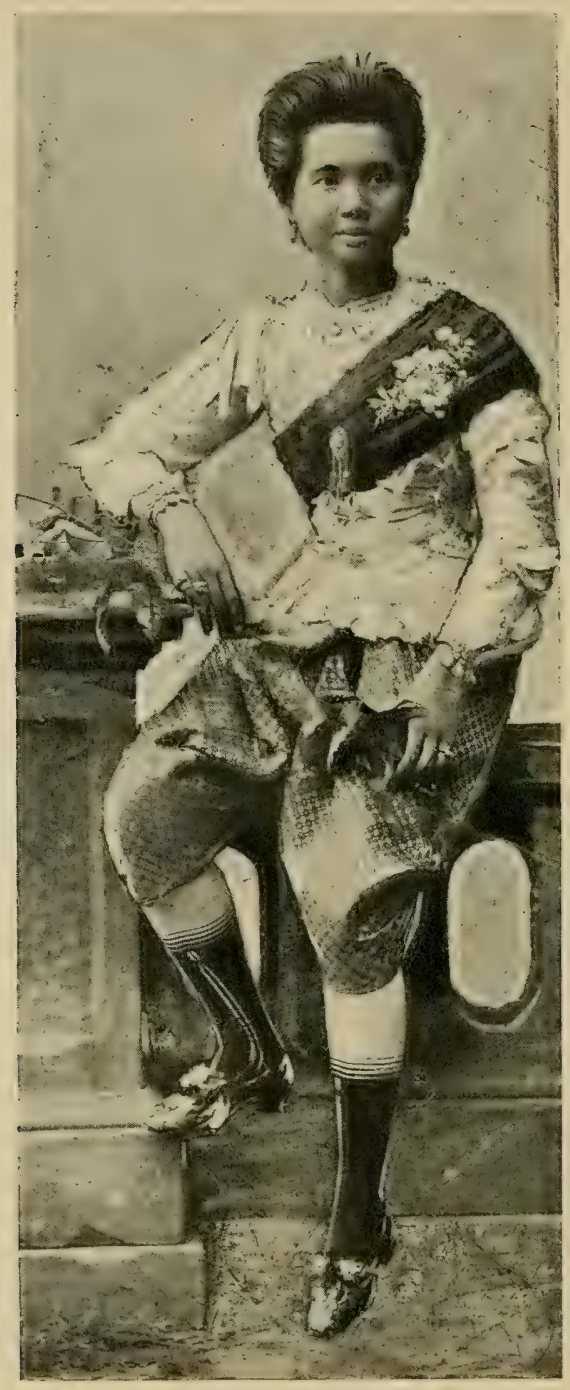

A Siamese Princess, Showing the trousers WORN BY WOMEN OF HIGH RANK. (See page 57.) 
their fashions, we find that in the time of the Saxons and Normans the barbarian style found favour once more.

In the picture of a Saxon fighting man (see Figure 80), we see that he wears trousers that somewhat recall those of the modern sailor, and there seem to have been many different styles even in those early days.

During the course of our history, long trousers went out of fashion for a very considerable period, though kneebreeches of various kinds flourished from time to time, until recently, when the original and less elegant garment once more triumphed and became part of the everyday dress of men. Boys still wear knickerbockers in one stage of their development, intermediate between the doffing of the petticoat and the donning of the trouser, and there is a tendency, that does not diminish, for the shorter garments to

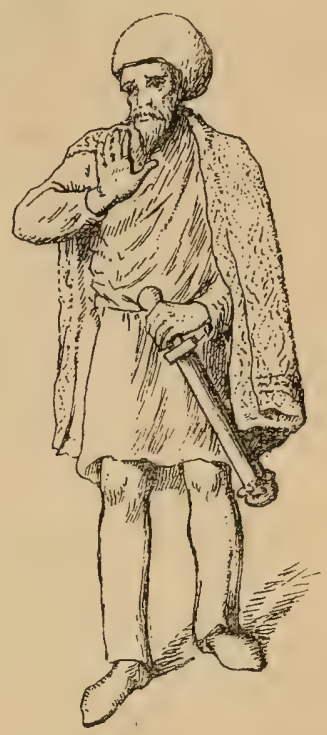

FIGURE 79.-A barbarian soldier wearing characteristic trousers (from a diptych of St. Paul, after Marriott). be used by men of all ages when they are not occupied with formal business.

Trousers, as has been indicated, are often wrongly thought to be a modern invention, and it is easy to go away with the idea that they are exclusively the attributes of men. This is far from being the case, and as in Scotland we find the petticoat still in use by men, so in France and Switzerland (see Figure 8I) we see the peasant woman wearing trousers of the ordinary type, to say nothing of Oriental countries like Persia and Siam (see Plate V), where trousers form part of the dress of women even of the highest rank.

We must not forget the energetic crusade which is being carried on in this country in favour of "rational dress " for 


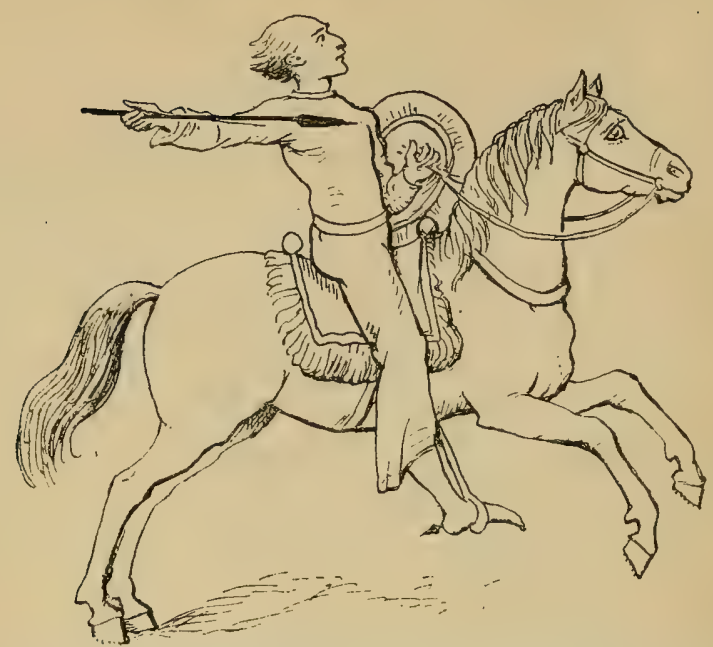

FIgURE 80.-A Saxon military man wearing wide trousers (from the Harleian MS., No. 603, after Fairholt).

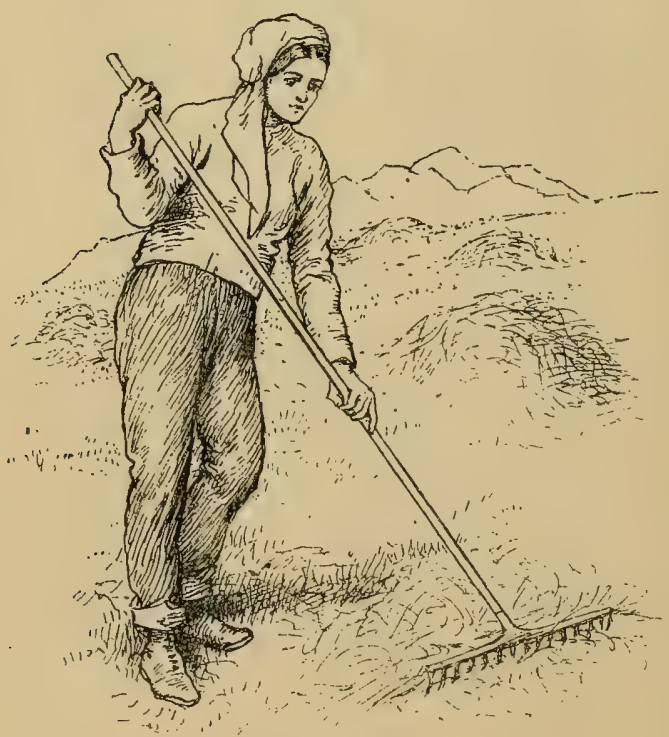

FIGURE 8I.-A peasant woman of Champéry wearing trousers. 
women, on lines which are more sensible than those laid down by Mrs. Bloomer, whose name has been immortalized in connection with divided outer garments for women. It is not intended, at the moment, to enter into a discussion of the advantages that may be gained by banishing the skirt, as we shall consider clothes, from the point of view of their effect upon the body, in a later chapter. Suffice it to say that the ugly clothes worn a few years ago by lady bicyclists who, while adopting divided garments, tried to make them look like a skirt, did much to hinder the "rational dress " movement.

There is one vestige in connection with trousers that we may mention before leaving this subject, and that

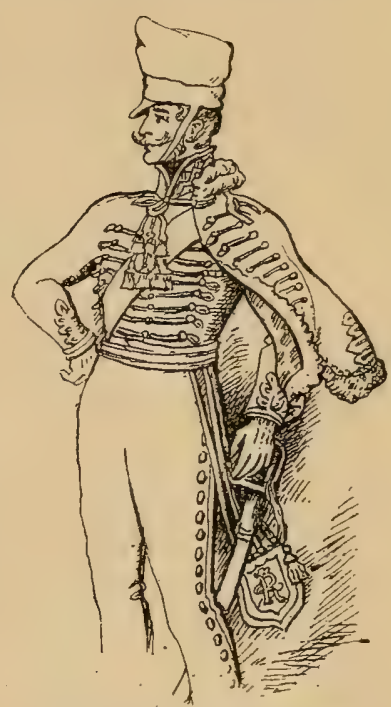

Figure 82.-A German Hussar of 1808 . is the stripes which are to be seen on many official dresses, and which have been adopted by some men in their evening dress of recent years. It seems that this takes us back to a row of buttons which were once used along the whole length of the breeches when these were too tight for the foot to be put through them, and in consequence the buttons had to be unfastened and done up again along the side of the leg. (See Figure 82.)

There is little doubt but that the stripe represents a fold of cloth that in some cases covered up these buttons. Just a few of such buttons are still to be seen on riding breeches and those worn by liveried servants. 


\section{IX}

\section{COATS OF ARMS}

SIGNET RINGS-ARMORIAL BEARINGS-ESCUTCHEONS

-CRESTS-BADGES

BEFORE we deal with coverings for the hand, it will not be amiss to consider something else which is worn on the fingers. Strictly speaking, of course, rings should be reckoned as ornaments, but signet rings very often bear upon them the crest or coat of arms of their wearer, and thus we have still carried on the person at the present day a small and inconspicuous vestige of what were once most important articles of costume. In fact; they had a significance as great if not greater than any others, for when the face of their wearer was hidden by his helmet they told to those well versed in heraldry not only his name but his lineage.

The crest was worn on the helmet, and might or might not be one of the devices or charges embroidered on the surcoat,-which was worn over the armour-and emblazoned on the shield and elsewhere.

At the present day, except in the case of ceremonial dress such as the tabards of heralds, the only survivals are the crest and shield. The devices on the latter are now called a coat of arms, as in olden times they were, as already indicated, merely a repetition of those actually worn on the dress or coat armour.

Let us compare for a moment the first two figures which illustrate this chapter. In the first (see Figure 83) we have a 


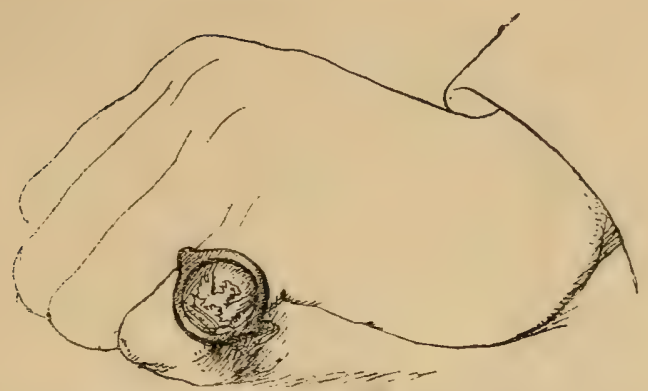

FIGURE 83.-The crest on a modern signet ring.

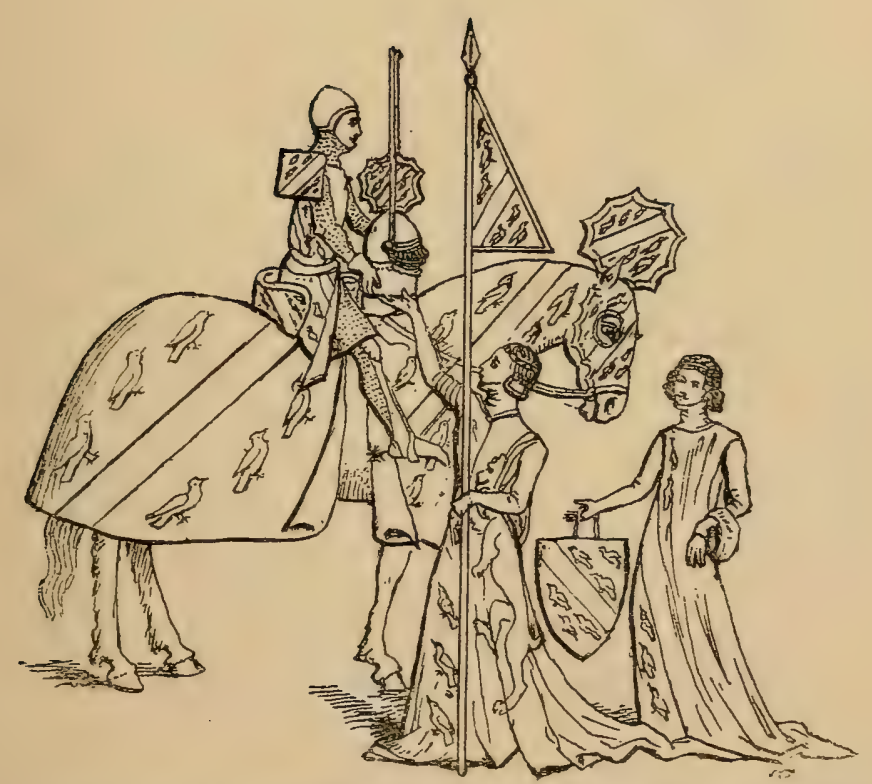

FrgURE 84.-Sir Geoffrey Loutterell and the ladies of his family, showing the extent to which armorial bearings were worn in the middle of the fourteenth century. From a psalter, made for Sir Geoffrey (after Fairholt). 
tiny device engraved on a ring that is worn on the little finger of the left hand. In the second (see Figure 84 ) we have Sir Geoffrey Loutterell mounted on his charger in the act of

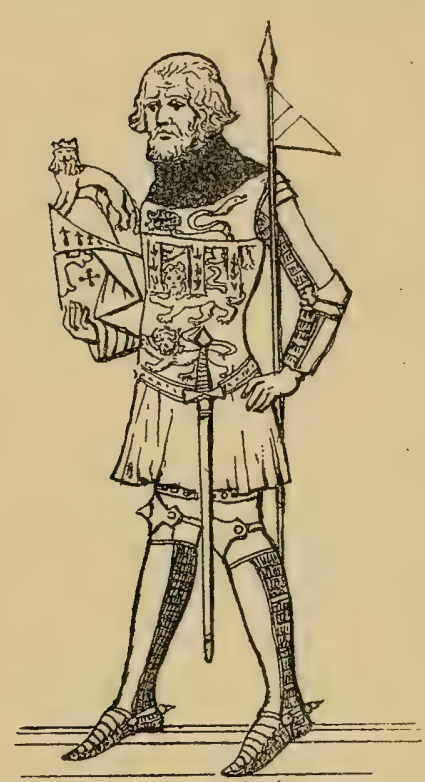

FIGURE 85.-The crest and surcoat of Henry, first Duke of Lancaster, A.D. I347. From the brass to Sir Hugh. Hasting at Elsyng, Norfolk (after Charles Boutell). receiving his helmet and shield from some of the ladies belonging to his family. All of the figures and the horse are decorated with armorial bearings. We wonder whether there could be a greater contrast. The knight has what is really his surcoat on his back displaying six martlets with a bend between them. The charges are repeated on a small square shield on his shoulder called an ailette; which was used apparently more as an ornament than as a protection, though it is said that ailettes were originally intended as a defence for the neck. Sir Geoffrey holds his helmet, on which, in the place of the crest, we again see his armorial bearings. They appear again on the pavon or small flag held by one of the ladies, and on the shield which the other carries. We find the same devices repeated five times on the trappings of his charger; and as if this were not enough, the ladies also have the bearings on their dresses. In the case of Lady Loutterell, who was the daughter of Sir Richard Sutton, there is shown also the lion rampant borne by her father.

We give another illustration taken from the effigy of Henry, the first Duke of Lancaster, on a brass at Elsyng, in Norfolk. (See Figure 85.) On this figure the surcoat is very well shown, 
and on it are emblazoned the three lions (or leopards) of the Royal Arms of England. It is interesting, too, owing to the label which differences the arms and shows that the wearer was not the king himself. The label takes the form of three vertical vars joined by a horizontal one, and is like that which may be seen to-day on the Prince of Wales's banner in St. George's Chapel at Windsor. In this illustration, too (Figure 85), the crest is very well shown.

Armorial bearings are still used to a considerable extent in architecture, but otherwise they are chiefly confined to notepaper, carriage panels, and harness. Occasionally "hatchments," or more properly "achievements," are put upon the fronts of the houses of important people on the death of a member of the family, and afterwards transferred to the church in which the body is buried. The hatchment consists of the arms of the deceased person, painted on a lozenge-shaped field, which is surrounded by a black frame, and if it indicates the death of a husband, the right half of the field is sable (black), the left argent (silver). If it is a wife that is dead, the colours on the field are reversed. When a widower, widow, or unmarried person dies, the whole of the field is made black.

In olden times the actual helmet, surcoat, and shield were carried at the funeral, and in some instances these were deposited over the tomb of the deceased. Examples survive to the present day, and one of the most interesting cases is to be found in Canterbury Cathedral, where the shield, helmet, and surcoat of Edward the Black Prince are still to be seen. (See Figures 86, 87, and 88.) The

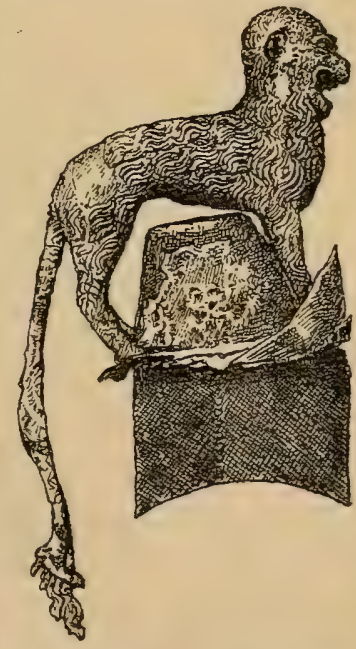

FIGURE 86.-The helmet and crest of the Black Prince. From "Vetusta Monumenta" (after St. John Hope). 


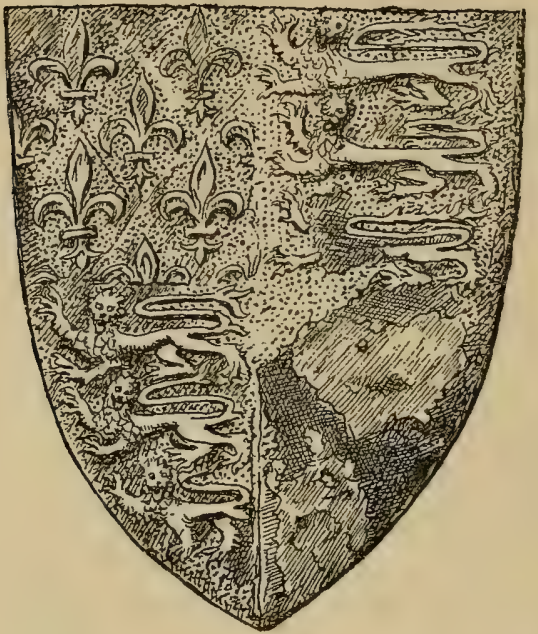

FIGURE 87.-The shield of the Black Prince. From "Vetusta Monumenta" (after St. John Hope).

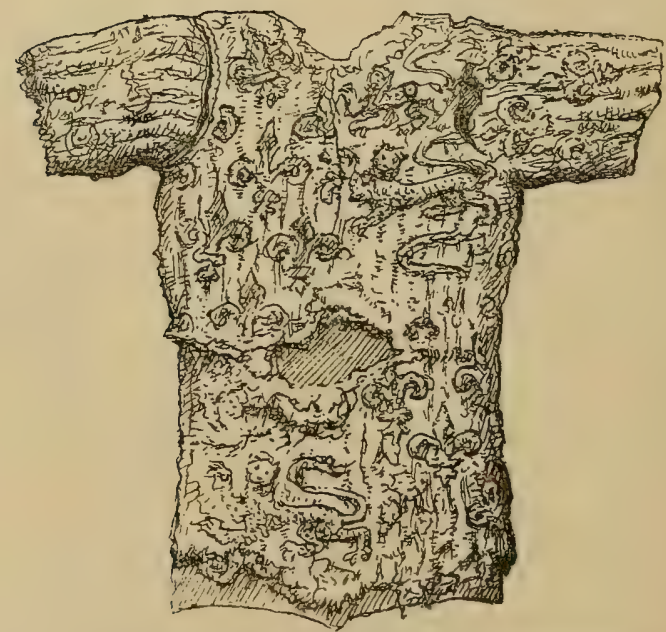

Figure 88.-The surcoat or jupon of the Black Prince. From "Vetusta Monumenta" (after St. John Hope). 
Black Prince left most careful instructions in his will with regard to his funeral, and the accoutrements which we are able to figure through the kindness of the Society of Antiquaries were the "arms of war," as he called them, that were to be carried at the ceremony. His "arms of peace" consisted of his ostrich feather badge, of which we shall again speak. There are traces on the crest and surcoat of a label to distinguish them, but this is absent from the shield, though it occurs on the arms many times repeated on the tomb, alternately with the feather badge already mentioned.

With the exception of the signet rings and the ceremonial dress, which were alluded to at the beginning of the chapter, there are now but few cases where armorial bearings are worn on the person. School and college arms are embroidered on the breast pockets of blazers and on the fronts of caps, while perhaps the most common instances are the devices which we see on the buttons of servants. Whole coats of arms may appear, but usually it is the crest of the master, which has now taken the place of the household badge which the retainers wore in olden times.

There is a difference generally between a crest and a badge, though in some cases the badge was really a crest. This was so before armorial bearings became hereditary, for the badge which the knight wore on his helmet formed its crest. Afterwards the same device was handed down to generation from generation. Individuals, possibly with a view of hiding their identity, sometimes wore a special badge instead of their family crest; but the badge as generally understood was worn by the retainers and was usually chosen by each head of the family. The matter is further complicated, because badges were sometimes hereditary and occasionally identical with the crest proper.

It is, of course, only the hereditary badges which have survived to the present day, and in only one or two cases 
are they apparently still used as such, though occasionally they survive for other purposes. The Prince of Wales's

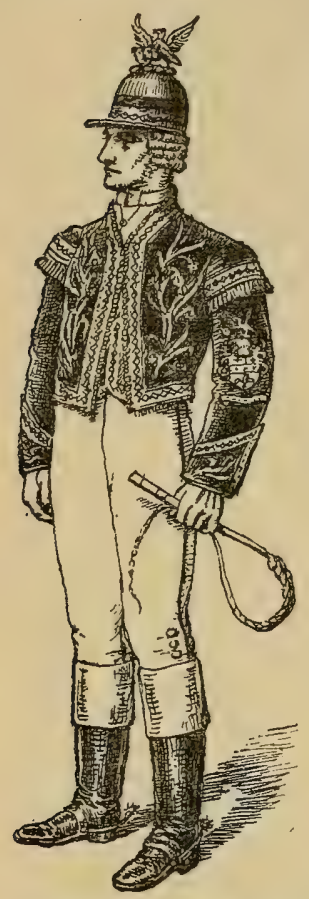

Figure 89. - The postilion of a Lord Mayor of London, wearing a crest upon his cap, and a coat of arms upon his sleeve. (Copied by permission from a plate published by the John Williamson Co., Ltd.) feathers we have already mentioned. They were not adopted by the Black Prince for the reasons usually given in history, as there is nothing to show that the King of the Bohemians ever wore them, and long before his time an ostrich feather was often used as a royal badge in England.

On his carriage, the Marquis of Abergavenny wears his badges, a rose and a portcullis, one on each side of his crest, and there are interesting cases here and there of badges worn as part of a livery. The porters of the Inner Temple wear the pascal lamb in silver. Watermen still have badges on their arms, and little more than a hundred years ago the private firemen of the insurance companies wore badges bearing the sign of the company. When speaking of signs, it is worthy of note that very many royal badges have furnished signs for inns. We cannot go into details, but we may mention the White Hart of Richard II, the Falcon and Fetterlock of Henry VII, now degenerated into the hawk and buckle, and the Rose and Crown also used by the Tudors.

Those who chance to see the dress of our convicts will hardly be inclined to associate it in any way with that of royalty. Yet it is true, nevertheless, that the broad arrow which marks-we can hardly say adorns-the garments of the penitentiary, is in reality a royal badge. The broad arrow 
can be traced to an ancient symbol consisting of three converging rods or rays of light used by the Druids, and it was adopted by Edward III as his badge. The symbol was also worn by the Black Prince and other Princes of Wales. As early as the year I386 the broad arrow was used in the Royal household, and from the beginning of the eighteenth century onwards it was adopted as a mark for distinguishing Government stores.

We may conclude our remarks upon this fascinating subject by alluding to a case in which a crest is actually borne on the head. It will be seen on looking at Figure 89 , which represents the postilion of a Lord Mayor of London, that he wears upon his jockey cap the actual crest of his master, just as in the days of chivalry the knights wore their crests upon their helmets. On his sleeve also there is a full coat of arms with helmet and crest, which takes the place of the badge, and is similar to the instances which we have mentioned just above. 


\title{
$\mathrm{X}$ \\ GLOVES AND MITTENS
}

\author{
ORIGIN OF THE BABY'S GLOVE-FOURCHETTES-THE \\ "POINTS" ON THE BACKS OF GLOVES
}

$G^{\text {LOVES }}$ play a considerable part in our everyday life, and now exercise a kind of mild tyranny over us. It is perhaps not to be wondered at, seeing the importance which has been attached to these protectors of the hand in the past.

Records show that in the earliest gloves there were no divisions between the fingers, and only the thumbs had a separate covering. This is what one might have expected to be the case, and if we look at the gloves which tiny babies wear (see Figure 90), we shall find a similar state of affairs, which may be a direct survival from very early times.

Actual bodily features which are ancestral are sometimes met with for a time in young animals: for instance, some belonging to species that originally were spotted like the leopard, but which in the course of their evolution have changed their spots, and are now, like the lion, self-coloured. Among other animals which are spotted when immature may be mentioned the wild boar and the tapir (see Frontispiece). While these young ones are protected by their parents, their primitive colouring is no detriment to them, but when they go out into the world for themselves it would be disadvantageous under existing conditions for them to retain their aboriginal markings. The baby can wear the primitive glove, 
which its ancestors made shift to use for purposes of warmth or protection, and the child continues to do so until it is necessary or convenient for it to use its fingers to help itself (without removing its gloves).

There is little doubt but that gloves are the products of a cold climate, and it is interesting to note that inIcel and, where, in order that gloves may be put on quickly and easily, they are made without fingers; and, what is more, so that no time shall be wasted in choosing right- or left-hand gloves, they are provided with two thumbs, one of which is in use while the other remains baby's glove without idle.

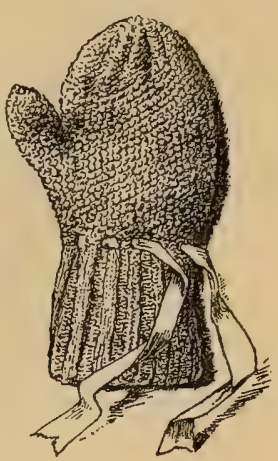

Figure 9o. - A

Of vestiges, gloves offer a very curious instance. There are on the backs of most of them, at the present day, three lines of raised embroidery or fancy stitching, which run almost parallel with one another, though they converge slightly as they approach the wrist. When these are worked in black on the back of a white woollen glove, for instance, they are very

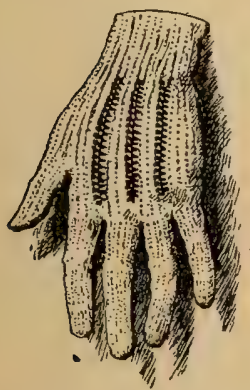

FIGURE 91. - The back of a woollen glove showing the three vestiges known as "points." conspicuous, and to explain their origin may well seem puzzling. (See Figure 9r.)

Inquiry into the history of these most persistent ornaments is apt to produce a fine crop of speculations. One explanation that may be offered is that the lines are vestiges that date from the time when gloves were so ill-fitting that they had to be laced up the back with the help of a string which was passed through eyelet holes. On hearing this, one might be tempted to ask why there should be three ornaments and not one. Another guess which can te more easily shown to 
be wrong is that we are dealing with the remains of ventilation holes. We say "more easily" because an

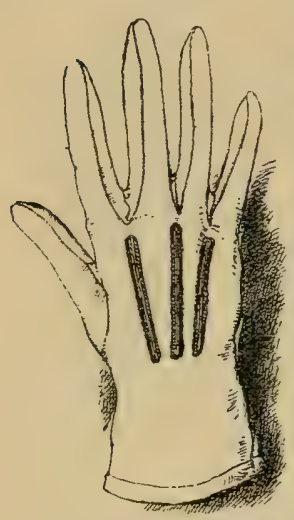
examination of the facts will show that openings through which air was intended to enter. were made in the palm of the glove.

A third suggestion which may occur is that the ornamentation is a survival from the time when great men, particularly prelates, had various devices and even jewels fixed to the back of their gloves. Once more, however, we meet with the difficulty in the shape of the point that there are always three of the marks.

FIGURE 92. - A In making a careful investigation into

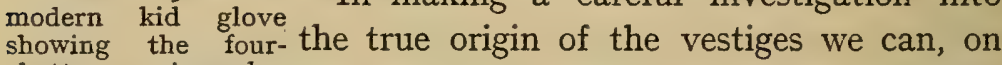
chettes or pieces be- the one side, endeavour to see whether
tween the fingers, which form three there is anything in the form of the hand pointed $V^{\prime} s$.

which can have given rise to the number three that is so constant; and on the other, whether the glove-makers have any particular name for the marks which may throw some light upon them. In connection with the first line of research, it will be seen on spreading out the fingers that there are, if we ignore the thumb which has its insertion lower down in the hand, three " $V$ "-shaped openings between them, and we find on taking up our second clue that the ornaments are called "points." Now there is a point at the bottom of a " $\mathrm{V}$," and this is well seen in looking at a glove where the pieces or fourchettes which form the insides of the fingers meet (see Figure 92); but if this is evident in a modern glove, it is very much more so in old gloves. (See Figure 93.)

A result of this fact was that the stitching which made the fingers was carried down for some distance on to the back of the glove, as seen in Queen Elizabeth's coronation glove. 
(See Figure 93.) According to Mr. W. W. Skeat (in "The Past at our Doors," I9ri), the seams were lengthened to make the wearer's fingers look longer and slimmer.

This stitching was and is often somewhat elaborate, and in some cases a line of embroidery covered it. This is well seen in the glove of Anne, the Queen Consort of James I (see Figure 94); and here it is noticeable that the two lines of embroidery

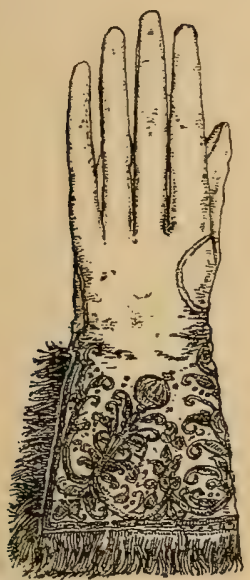

Figure 93.-Queen Elizabeth's coronation glove, showing the stitching (which serves to keep in place the pieces between the fingers) carried down on to the back. (From a photograph, by the courtesy of Messrs. Fownes Brothers and Co.)

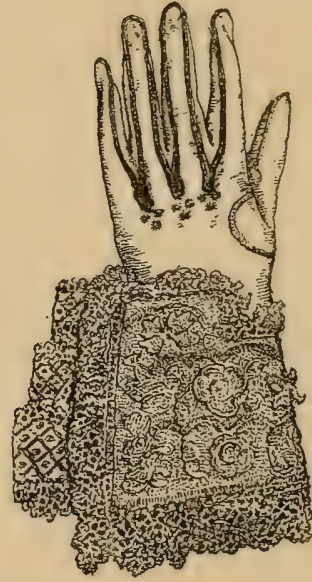

FIgure 94 -The glove of Anne, Queen Consort of James I., showing the embroidery on the fingers, which is the ancestor of modern "points." (From a photograph, by the courtesy of Messrs. Fownes Brothers and $\mathrm{Co}$.)

at the points of the three "V's" run parallel to and touching each other, so that we get a beginning of the three "points" as we know them. With improvements in the making of the fourchettes, the stitching terminated more abruptly, and the embroidery was allowed to remain on the back of the glove, where it is still to be seen.

Some mention should perhaps be made of mittens. When they are used for the purpose of keeping the hands warm, they 
are usually on the principle of a baby's glove, but with the end of the thumb and part of the bag for the fingers cut off. Otherwise, when these articles are used merely to cover part of the hands, or for ornament, they are more elaborate, and divisions are introduced for some distance between the fingers. In the construction of these, as in that of stockings and other garments, we meet with the modern tendency towards transparency. Often also the patterns are dependent upon the skin showing through, and we are once more reminded of tattooing. 


\section{$\mathrm{XI}$}

TAGS, PINS, AND BALDRICS

LACES-THE EVOLUTION AND VAGARIES OF THE SAFETY-PIN -PRIMITIVE METHODS OF CARRYING BURDENS AS ILLUSTRATED BY MUFF-CHAINS, BALDRICS, AND YOKES

DURING the course of their evolution many little appurtenances in connection with dress go through a number of changes. Some of them, which at first are useful, afterwards become ornamental. Others, which have reached a stage in which they are both necessary and decorative, may for a time be simplified and retain a practical importance only, while at a later period they resume their ornamental character once more.

We have at the present day various laces which are provided with simple metal tags, and which are as primitive as they very well can be. (See Figure 95.)

If we examine the dresses of both sexes in the sixteenth and seventeenth centuries, we shall find that ties were used to a great extent instead of buttons, and they were provided with metal tags of an ornamental character called aiglets, or, more properly, aiguillettes. In many cases the chief object of the ribbons which they adorned was that of embellishment, for as many as a dozen or more might be found round one knee. Sometimes the tags were in the form of little figures, and in the "Taming of the Shrew" it is said of Petruchio that if you gave him gold enough any one " might marry him to a puppet or an aglet-baby." 
Of recent years the velvet ribbons which ladies have worn round their necks have been provided in like manner with

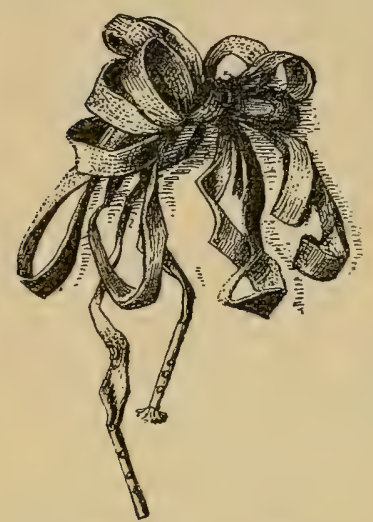

FIGURE 95.- A silk lace with simple metal tags. little tags (see Figure 96), though the fashion does not seem to have developed again to any very great extent.

The safety-pin is an object which may well occupy our attention for a moment. As we knew it when we were children, it was merely a piece of wire that had been pointed at one end and bent into the required shape. (See Figure 97.)

The point was protected in a very simple manner, and the safety-pins used for fastening hooks to curtains are still constructed in the same way. Occasionally gold safety-pins of a plain and even ornamental character were made and used as brooches by ladies for fastening lace, or by men for securing their ties in the place of the straight scarf-pins. It would seem therefore that a brooch is a development of the safety-pin rather than the reverse; but if we study the brooches or fibulæ of the Romans, we shall find that the pin, instead of being hinged, was often made in one piece with the rest of the structure. A coil or two in the metal acted as a spring, as in the case of the safety-pin, and prevented breakage. We may even find an Etruscan fibula of such simple construction (see Figure 98) that it is to all intents and purposes a safety-pin, and it is stated that. similar methods of fastening clothes were in use as early as 2000 B.c. All sorts of devices have been invented for the better protection of the points in modern safety-

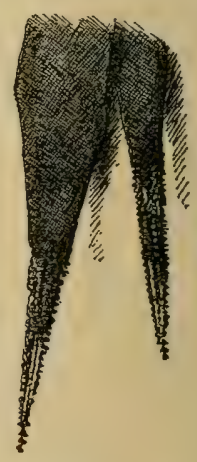

FIGURE 96.Ornamental metal tags on a velvet neck ribbon. 
pins, as well as for rendering the opening and closing more easy; but this is the development which has taken place along practical lines. Such pins are for use only, and are not intended to be seen. When, on the other hand, safety-pins are not hidden, they retain their more simple character as regards

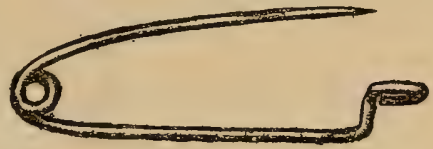

FIGURE 97.-A simple safety-pin. their fastenings, though they themselves again become decorative, and are ornamented in various ways. We have therefore a very good illustration of the evolution of one thing along two different lines, and of the survival of the fittest types in each case.

The ornamental safety-pin in recent years has changed its habits, and it is interesting to note its vagaries. A little while ago its sphere of action was extended, and instead of figuring under the chins of ladies it took up a position in the back of their waistbands (see Figure 99), where it occupied itself with the duty of keeping blouse and skirt together. Then, as if this situation were not important enough, the safety-pin migrated to the head and usurped the place of the straight hat-pin (see Figure I00), just as in the case of men it has sometimes ousted the tie-pin proper.

During the process which we have described, the safety-pin has become stronger and larger, until in the last stage it has grown almost almost out of recognition.

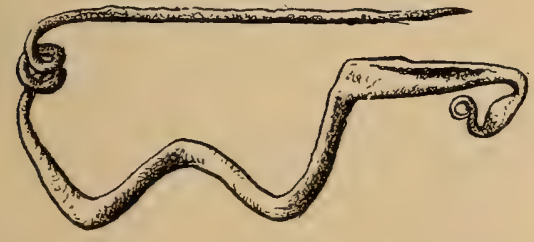

Straight pins have developed along the same two lines, and we have the strictly useful pin and tie- or hatpins, which are often quite as important as

FIGURE 98.-An Etruscan brooch or fibula, fastenings, but which resembling a safety-pin. (In the Myers' may also be highly
Collection, Eton College Museum.) 
ornamental. These small articles have a special claim to our attention, as they have been taken as being emblematical of clothes, or at least of female attire. Even now the

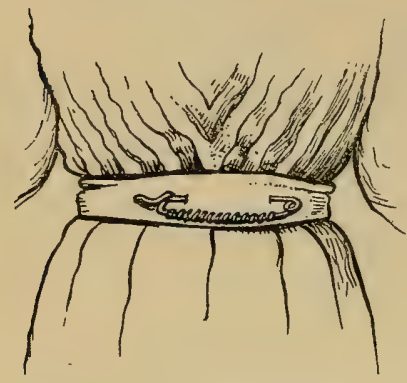

FIGURE 99.-The safety-pin in the waistband. allowance which a lady is given for dress is called "pin-money." Moreover, it is possible to illustrate by means of pins the various phases of culture through which mankind has passed in the process of civilization. We meet with pins of bone, in the stage of stone, before metals were used. In the stage characterized by bronze we have pins made of this alloy. Such pins occurred in Egypt before the historic period, and they have been found in the Swiss lake dwellings as well as in our own country.

Although we now live in the iron, or perhaps more correctly steel, stage of culture, the familiar pin of to-day is still usually made of brass; but nevertheless we find steel pins of the ordinary form which are plated with brass, and glassheaded steel pins are very common. In early times gold, silver, and precious stones were also pressed into service for making ornamental pins, and very handsome pins are represented on effigies of the fourteenth century in Westminster Abbey. These, no doubt, have for their descendants the scarf-pins of to-day.

A muff-chain is a thing which is very often seen at the present day, and this simple arrangement, coupled with the way in which it is worn (see Figure Ior), may lead us along a very interesting line of research, which we may follow for a short time. If we look once again at the muff, we shall see that it is supported by a chain which goes round the back of the neck, allowing the muff to rest against the front of the body. This is a primitive method of carrying a burden. 
Pedlars of old made use of it, and it is still adopted by the hawker (see Figure I02), because, if necessary, the hands can remain free, while a modification of the same principle is seen when the strap takes the form of a baldric, and passes over one shoulder and under the arm on the other side. In this way travellers carry their courier-bags (see Figure 103), the school-boy or girl supports his or her satchel, FIGURE roo.-The safety-pin grown larger and the fisherman his

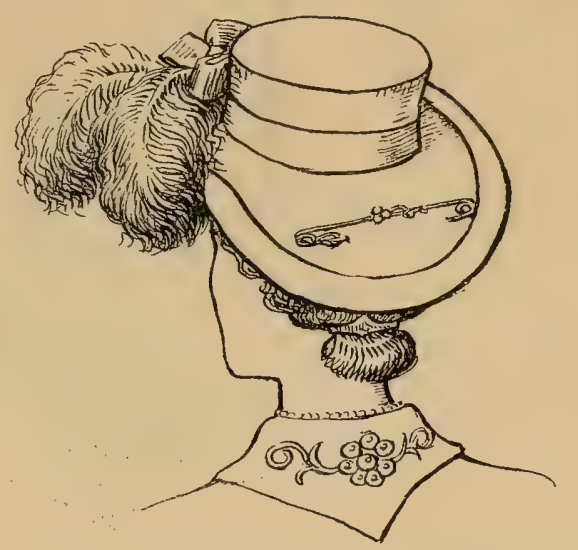
creel, and the sportsman his field-glasses. To a baldric also was attached the quiver of the archer, and sometimes such a band was merely worn as a decoration. (See Figure

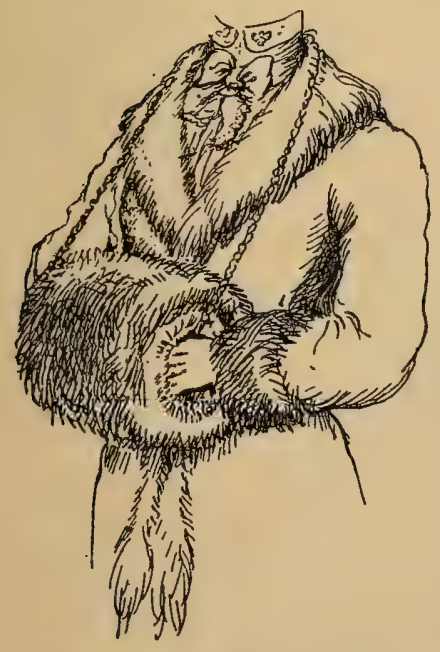

FIGURE IOI.-A muff-chain. I04.) In the illustration which we give, and which is of the time of Henry $V$, the baldric is hung with bells like those which were worn by horses. Possibly a survival of the ornamental use of the baldric is to be seen in the ribbons of various orders and in military sashes, though no doubt the bandoleer which carries the pouch or cartridges of a modern soldier represents the useful baldric. It is of interest to note that the red or blue cord worn over the cross-belts of the Life Guards and Horse Guards is a 


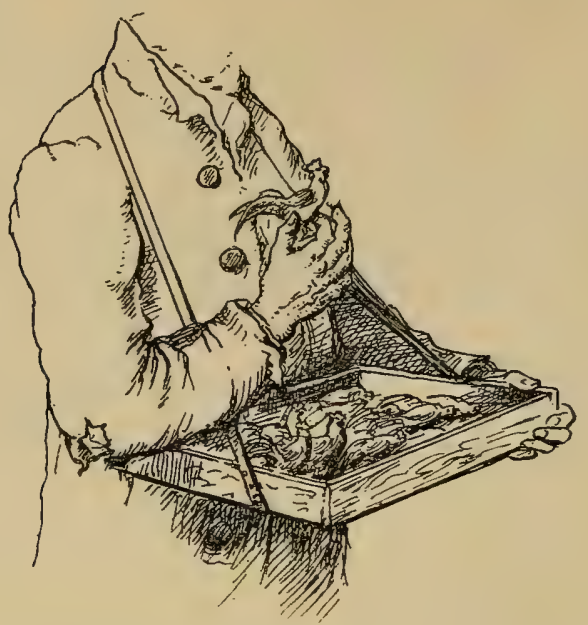

FIGURE I02.-A hawker, illustrating the primitive way of carrying a burden.

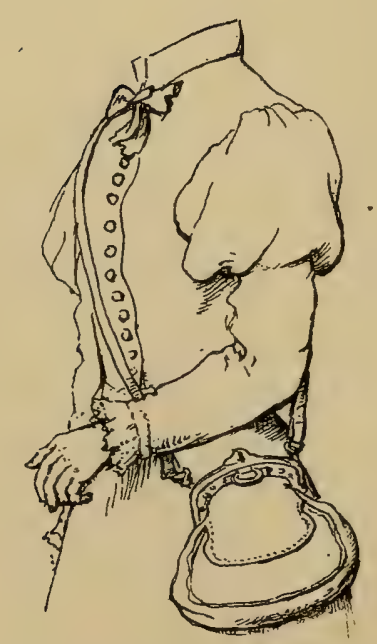

FIGURt I03.-A courier-bag supported by a baldric. 
survival of a cord by which the horn containing powder for priming muskets used to be suspended. In this connection we might also mention the leather sling of a rifle and the strap by which the itinerant harpist, in common with the organ-grinder, carries his instrument.

The ordinary belt should not be overlooked, as from it many things, such as weapons, may be suspended, not to mention pouches, which may carry ammunition, flint and steel, and so on.

Even more intimately connected with dress are pockets, and they

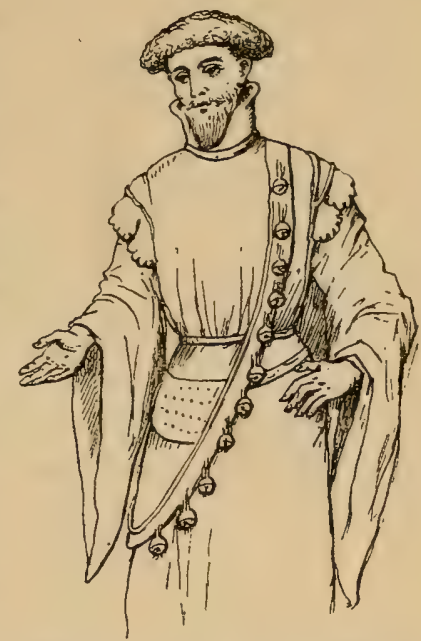

FrGURE 104.-An ornamental baldric of the early fifteenth century. (Royal MSS. I5 D, 5, after Fairholt.)

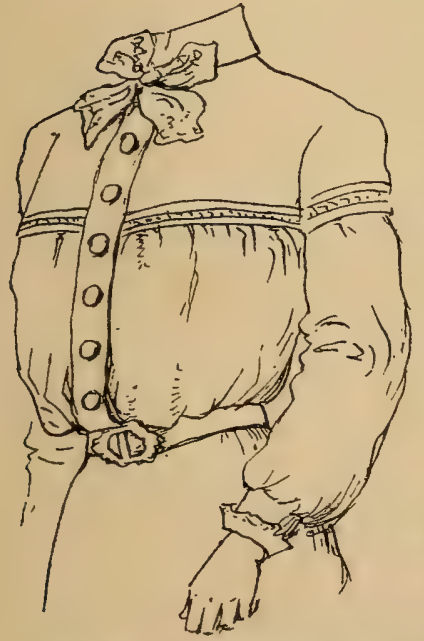

FIgURE ro5.-A lady's dress, showing the part which is called a yoke, and recalls a primitive method of carrying burdens. may be touched upon here, for they are intended for carrying small objects. We have seen how the flaps of pockets which have become ornamental survive after the pockets themselves have disappeared (see Figure 2I), and it is worthy of note that clothes in various countries lend themselves to the transportation of commodities. It has been pointed out by Mr. Otis T. Mason ${ }^{9}$ that the Oriental, especially the Korean, has pockets in his sleeves having the capacity of half a bushel; while the Turk and Arab can stow an equal amount in the ample folds of their robes, The writer also 
remembers hearing the account of a journey in Asia from a traveller who, when riding in wide trousers fastened at the ankle, used to keep all his clean linen in one trouser-leg and his dirty clothes in the other.

We are reminded by the name given to the upper part of a lady's dress, namely the yoke (see Figure I05), of another means of carrying burdens, which still survives in London, where a few milk-women even now carry round their pails on a yoke. Their costume, which includes a small shawl and an apron, can be compared with that of the barge-girl, though the picturesque sun-bonnet of the latter is lacking. 


\section{XII}

\section{ORNAMENTS}

PRIMITIVE NECKLACES-FINGER-RINGS-THE ORIGIN OF THE HAIR-COMB - BUTTONS - STUDS - FLOWERS - FEATHERS AMULETS

$W^{E}$ have touched upon one or two objects which may have a decorative character, but we now come to a consideration of ornaments themselves. Roughly speaking, they owe their survival to one of two reasons: either the deep-rooted instinct which exists in even the lowest races for adorning their person, or, secondly, the adoption of various objects which have been worn as charms or amulets.

Dr. E. B. Tylor ${ }^{10}$ has pointed out the tendency of higher civilization to give up savage ornaments. Not the most primitive possibly, but seemingly the most barbarous, are the ornaments which are fastened into the body in special orifices which are pierced to receive them. It is true that in this country we do not make holes in our lips for the insertion of wooden plugs two or three inches across, and the only nose ornaments which we see are on the faces of the Hindu ayahs who have come over from India with their white nurselings; but still many among the population pierce their ears for the reception of ear-rings. In the higher social ranks ear-drops are now worn which do not require the ear to be perforated for their reception; but among the lower ordersas, for instance, those who live in canal-boats-the ears of men, women, and children are still pierced. 
Of ornaments which can be attached to the person without injuring it there are more in use, but they are practically confined in civilized countries to the neck, arms, and head. Of those which are fastened to clothes we will not for the moment speak. Beads, or their representatives, take us back to the very earliest men of whose work we have any knowledge. In the caves where the Stone Age men of the mammoth period lived there have been found periwinkle shells which were bored to form bracelets or necklaces, just as nowadays native tribes and æsthetic ladies still make use of the more ornamental and beautiful exotic shells. The prehistoric Egyptians who, it has been calculated, flourished about 6000 B.C., had necklaces of beads cut out from pieces of shell, and others made of many different materials. Among the earliest remains in our own country beads are found, and throughout the historic period everywhere they seem to have held their sway.

We have already mentioned how easy it is for ornaments to be used as currencies, owing to the facility with which they may be carried on the person, and beads for many centuries have been used-as in Africa for instance-in the place of money. There are on the west coast of that continent still to be seen "aggries" similar to those which the Arab traders brought with them from Egypt as early as the seventeenth dynasty. At the present day beads of various kinds-for only particular varieties will buy certain commodities-are made and exported to Africa to be used in trading.

While speaking of Egyptian beads, it might be said that, as in other matters of art, the Egyptians excelled in their making. Some-known as blue popo beads, which found their way to West Africa - are worth more than their weight in gold at the present day, and the most skilful of the Venetian beadmakers are unable to imitate them sufficiently well to induce the natives to accept them.

Chains for the neck in our time do not assume very massive proportions, except those which are used as symbols of office 



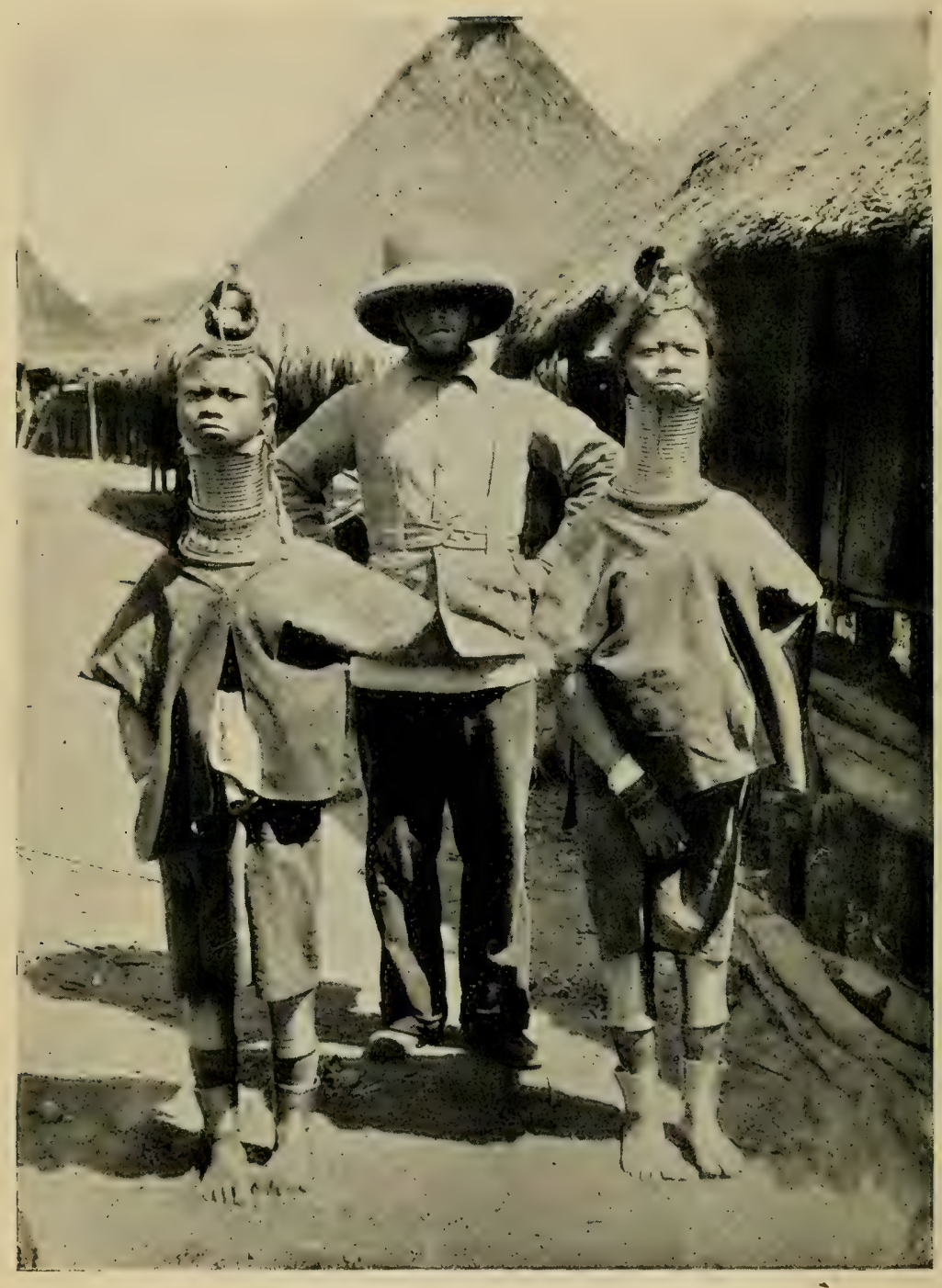

Two Padaung Women, showing the nUmerous metal Col.tars Which THEY WEAR ROUND THEIR NECKS. (See page 83.) 
in the case of mayors and by the members of various knightly orders. These take us back to the time of Richard II, when such ornaments came into vogue.

Among savage races metal rings find much favour as ornaments, and they illustrate the fact that the lady who wears the minimum of clothes will put up with the height of inconvenience, not to say pain, just as her over-dressed and more civilized white sister will do, in order to be in the height of fashion. The Padaung women put metal collars round their necks when they are young children till these number between twenty and thirty, and the necks of the wearers are stretched out in the most grotesque and uncomfortable fashion. (See Plate VI.) African belles will wear great copper rings on their limbs, which get so hot in the sun that an attendant has to carry water with which occasionally to cool them down. The wearing of armlets and bracelets has never been confined to women. Men among the Greeks did not wear them, but among the Romans they did. Armlets were conferred on soldiers for herioc deeds, and even now the rank of noncommissioned officers in the army is indicated by stripes on their sleeves.

Dr. Tylor hints that ordinary finger-rings originated with those used as signets in Egypt and Babylon. In this case the modern signet ring, which we have already discussed in connection with heraldic devices, is a survival from the earliest times. Most rings are now merely ornamental, though a few are symbolical-the episcopal ring of the bishop, the engagement ring of the betrothed damsel, and the wedding ring of the wife.

As eariy as the seventh century a ring was among the distinctive insignia of a bishop, and one was found on the finger of Bishop Agilbert of Paris (who lived at this time) when his coffin was opened. The ring was of gold, and, as is usual, had a jewel set in it, on which, in the particular case mentioned, was a likeness of Christ and of St. Jerome. The origin is no 
doubt to be found in the fact that in Roman times rings were used as insignia of rank.

The episcopal ring proper was only one of many other rings which a bishop might wear as ornaments. It was borne on the third finger of the right hand, above the second joint, and was usually kept in place by a plain guard ring.

The Greeks and Romans used betrothal rings as pledges, but not wedding rings. There is a good deal of interesting symbolism in connection with rings, and it is said that the third finger of the left hand was chosen because in old times it was thought that a vein came to that finger direct from the heart. The practical point is that the finger in question is not very much used, and on it the rings would not be so liable to be worn out as on some of the others.

It is also supposed that the left hand was chosen as it was the less important, and the wearing of a ring on this hand signified servitude. An interesting form of early wedding rings was that called the gimmal ring, which consisted of two links, each having a hand upon it, which when brought together formed a single ring with the hands clasped together. The ring was used at betrothal, and the man and woman each kept a half until their wedding day. Perhaps the old custom of breaking a coin upon engagement, so that each of the contracting parties may have half, is a relic of the same custom. In Ireland the peasantry still use a ring, though a solid one, bearing clasped hands. It has been said that the wedding ring is all that remains of the house key which the husband gave to his wife on their marriage.

We have possibly a survival of the interesting posey rings in those which bear the word Mizpah. This originally signified " a watch-tower," but it is now taken as expressing the following sentiment: "God watch over thee and me when we are apart." In the fourteenth and fifteenth centuries the couplet or line was, as in the case mentioned, put on the outside of the ring, while later, in the sixteenth and seventeenth 
centuries, the words were engraved inside the ring. Occasionally we see a necktie held in place with a ring, and this may well be connected with the custom of wearing rings round the neck on a ribbon. It is recorded that the Duke of Burgundy, who died in 1476 , carried his signet ring in this way.

A custom is still sometimes followed which dates back to the sixteenth century. It is that of choosing stones on account of the first letters of their names and setting them in a ring in such an order that the initials spell a word or words. For instance, the followingRuby, Emerald, Garnet, Amethyst, Ruby, and Diamond, indicate REGARD; while a lover's exhortation is produced by such a combination as Lapis-lazuli, Opal,. Verdiantique, Emerald, Malachite, Emerald.

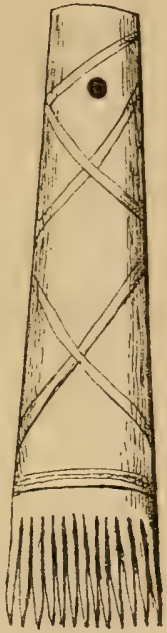

Figure ro6.-A loom comb found in the Glastonbury lake dwellings blue pottery or faience, and some of them (after Boyd show highly ornamental and pierced work.

The lotus flowers and other figures upon them point to their being symbolical. Others bear the sacred eye in the place where the seal would be in a signet ring, and were probably used as amulets; but of orna-

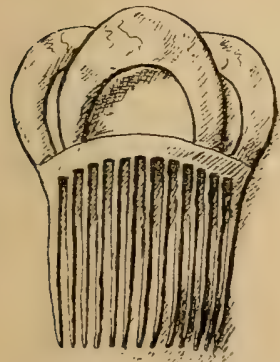

Figure 107.-A modern comb for the hair. ments worn on account of their supposed virtues we will speak in a moment.

An ornament for the head, with which we will deal, is the crown. Mr. Elworthy, in a paper to the British Association at Ipswich in I895, derived the crown from horns of honour. He maintained that the symbols found on the head of the god Serapis were the elements from which were formed the composite head-dress 
called the crown, into which horns entered to a very great extent. The panache in heraldry is derived from the horn, and it may be recalled that the deerskin cloaks worn by the Bronze Age people over the woven dresses that have been described on pages $I 8$ and 53, bore the horns of the animal from which they were taken.

Though the comb used as an ornament in the hair is also worn on the head, it is on a very much lower plane than the crown, and has presumably a very much less exalted origin. Professor Boyd Dawkins ${ }^{11}$ has expressed the opinion that the old loom comb (see Figure I06), such as one found in the prehistoric lake dwellings which have been excavated at Glastonbury, is the ancestor of the comb worn as a head-dress at the present day (see Figure I07). Combs were used to push down the weft on a hand loom, the warp being kept taut by means of weights. The long hair-combs used by the natives of the West Carolines are also of very much the same shape as the old loom combs.

Already in the safety-pin and scarf-pin we have had instances of fastenings which at times are ornamental. The button and its relative the stud afford another case in point. A stud is in reality a button which appears on both sides of the stuff through which it is put. It is obvious that it is most convenient to use when the material to be fastened is of a stiff texture. At present we use studs in our starched linen, and they are also adopted for fastening parts of leather accoutrements, as they evidently were in the times of the later bronze folk. This will be seen from Figure I08. One of these is adorned with the triskele, which is allied to the swastika, and no doubt gave rise to the three-legged charge on the coat of arms of the Isle of Man and of Sicily.

Buttons have from time to time done a great deal in the way of decorating clothes, in addition to the part which they have played as fastenings. We saw in an earlier chapter how many of our buttons, which are now only ornamental, were 
once of use, and any history of costume which goes into details will show how largely superfluous buttons have figured as ornaments. The members of the Society of Friends in its early days, of course, refused to wear any buttons that were not needful, and brought down upon them the criticisms of Cobbett, who referred to other things which they lacked besides buttons. Although at the present time we may be inclined to appreciate some of our purposeless buttons, on account of their historic associations, we cannot say the same for many of those which of recent years have appeared on
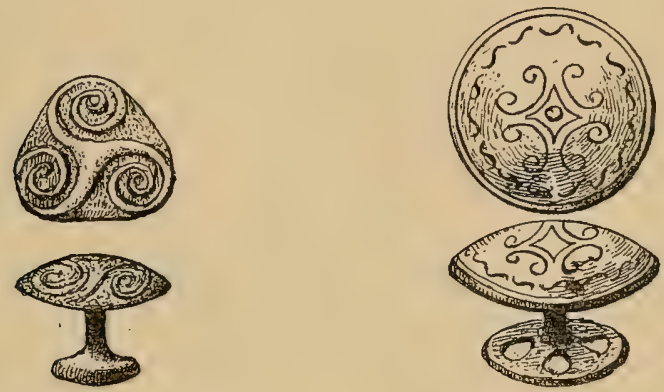

FIGURE I08.-Two studs of bronze, seen from above and from the side. Later Bronze Age (after Worsaae).

ladies' dresses. There is little sense in having on the front of a bodice a series of buttons of which the first member is very large and the last very small, with the others graduated in size between them, while there seems to be no rhyme nor reason in many other individual buttons or patches of them which may be dotted here and there over the costume. It is not as if these additions were really handsome. Not long ago they looked as if the wearer had saved up all her old glove buttons, and then had sewed them to her frock, for they were quite tiny and made of brass. Now, though they are larger, they are merely covered with the cloth of which the dress is made and are usually quite plain.

In some cases buttons show great beauty of design, and for 
this reason, if not on account of the material of which they are made, may be exceedingly valuable.

Bearing on the antiquity of buttons, we may say that they are found among prehistoric remains in this country, and though they were foreign to the ancient Egyptians, we learn (through the kindness of Professor Flinders Petrie) that - engraved buttons or seals were usual from the sixth to the nineteenth dynasty, probably among foreign immigrants, for the designs are never true Egyptian. In the year I907, Professor Petrie found a carnelian button with a copper shank which belongs to the twelfth dynasty.

The use of flowers, whether artificial or natural, on the person, and more particularly the wearing of feathers, also takes us back to the primitive instinct of early or uncivilized man.

In our own country the custom of wearing feathers is an exceedingly old one. The single upright specimens used by the knights of the fourteenth century have been characterized as being preposterous in size. The plumes afterwards worn in helmets in the fifteenth and sixteenth centuries were also immense. In 1606 , according to Nichol's " Progresses," on the occasion of the visit of Christian IV, some of the knights " wore strange feathers of rich and great esteem which they called Birdes of Paradice," and, unfortunately, ladies of the present day wear them still. In the reign of Edward IV, we learn, only men, practically speaking, wore feathers. They still survive in the army and on the hat of the Lord Mayor's coachman, but otherwise in the twentieth century, with the exception of an occasional small and modest instance amongst civilians, the wearing of plumes is confined to ladies.

Many flowers and feathers are exceedingly beautiful, and from an artistic point of view there seems little reason why we should allow civilization to sweep them away. We are quiet and colourless in our clothing, and if we are not careful the same element of dulness may creep into our lives. At the 
same time, however, to wear feathers which can only be obtained at the cost of cruelty or of depriving others of the sight of beautiful birds, or, again, of bringing any species to extinction, savours too much of barbarousness and thoughtlessness to be in any way condoned.

Ostriches are reared for their feathers, and the plumage of many birds that are preserved for shooting, or killed for food is always at hand.

Men have much less opportunity now of showing any great individuality in their dress than heretofore, but sometimes they may be known by always wearing a buttonhole, even if that does not always consist of the same kind of bloom. The language of flowers, though now seemingly considered to be a dead letter, was hardly invented for nothing.

Of the brooch and its connection with the safety-pin we have already spoken. In many ornaments we find remnants of religious ideas; for instance, all brooches showing a crescent pattern or bearing the design of a hand are connected with the old phallic worship. The cross, it may be mentioned, is of much more ancient origin than Christianity, and is connected intimately with the swastika or fylfot.

The locket and other pendent ornaments must in many, if not all, cases be the descendants of amulets. The Arab women at the present day wear a little metal box containing a written talisman. An ancient Egyptian buried, with his mummies, many amulets and charms so that the soul, in obedience to various precepts, might enter into complete union with $\mathrm{Ra}$, the solar god, and so accompany him on his journey round the world, and secure his everlasting protection.

It is due to these ideas that we owe the beautifully modelled figures of glazed pottery found in the Egyptian tombs. Many of them depict the various gods and goddesses acknowledged in Egypt, and they are usually pierced for attachment to the person. These were also carried on the person during life, and children especially were accustomed to wear them. 
Old religious beliefs and superstitions that have not yet died out, have elsewhere given rise to the wearing of charms, and it is interesting to note that flint arrow-heads, under the name of " elves' arrows," were made into pendants by races who had reached the metal stage of culture.

Precious stones, upon which a word may be said here, no doubt at first were prized for their beauty alone, and then imagination gradually endowed many of them with fictitious properties and virtues, though doubtless the supposed attributes of some and the value and beauty of others have kept many precious stones in favour until the present day. Fashion is now particularly fickle as regards them, and craftsmen who deal with gems feel her decrees ${ }^{12}$ more keenly perhaps than anyone else. Some half-dozen kinds of stones-such as diamonds, rubies, emeralds, sapphires, opals, and turquoises-never go completely out of fashoin, but even among these one or other becomes paramount from time to time.

The topaz and chrysolite were reported to lose their brilliancy when placed in liquid that contains poison. To the amethyst was attributed the power of warding off the effects of drunkenness. The diamond, it was believed, gave to the wearers magnanimity, virtue, and courage. The ancients supposed that the opal shared the charm of every stone of which it reflected the colour, but when it was stolen the thief became invisible, and was allowed to escape scot free. Mr. Claremont $^{13}$ has made an interesting suggestion as to the reason why the opal has been considered unlucky. The notion, he says, is not nearly so ancient as many of the superstitions relating to other stones, and probably does not date further back than the Middle Ages. The old name " ophal " was used as late as the time of Queen Elizabeth, and came from the Greek for " eye "-stone, and as eyes are considered unlucky even in peacocks' feathers, perhaps the explanation of the superstition lies in the name of the stone.

Such walking-sticks as those garnished with "sylver" and 
"golde," which are described as being at the Royal Palace at Greenwich in the reign of Henry VIII, may well be considered as ornaments. The same may be said of the beribboned canes of the exquisites of Charles II's and later times. We mention them because, within the last two or three years, there has been a talk of seeing "the nice conduct of a clouded cane " more generally considered, and some men have appeared at the theatre with long, gold-knobbed and tasselled canes.

The buckle, which may be ornamental or useful, or both, is well worthy of our attention. It consists in its simple form of a ring and a pin, and the latter is hinged on to the former. It is, in fact, much like a brooch, but without a hasp, and used in a different way. There are brooches, however, at the present day which are even simpler in construction than the buckle, and they are used ${ }^{14}$ even now by blacksmiths in Kirkcudbrightshire, in the form of the iron ring and a horseshoe nail, with which they fasten their aprons. Similar pinring brooches were used in Ireland until quite recently and are known from early times. Mr. Edward Lovett ${ }^{15}$ thinks that such a fastening may well have been derived from two bones of the sheep or deer, the garment being pulled through the ring formed by half the hip girdle, and speared through with the pointed heel bone.

A still more primitive pin was no doubt a thorn, and fishhooks are to this day used on the coasts of Essex, which are made from the same natural object. 


\section{XIII}

\section{HAIR DRESSING}

\section{HEAD SHAVING-WIGS THAT ARE STILL WORN- ROMAN CURLS AND FRINGES}

$\prod_{\text {connected with fashions in costume that no excuse is }}$ needed for dealing with the question here. Moreover, there are certain vestiges in costume occasionally to be met with which owe their origin to the way in which hair was once arranged. Hair can be treated in all sorts of manners without injuring the person in any way, and usually without causing pain, though some fashions in hair arrangement had results that were far from pleasant, and must have caused considerable discomfort.

In addition to the styles in which hair is allowed to grow, there are others which lead to its removal from one or more of the places which it normally covers, and almost every change that could be rung is met with. In addition to the hair on the head, women have only their eyebrows and eyelashes to consider, though it is the fashion to remove any "superfluous" hair from their faces and arms. Men have also to deal with moustaches, whiskers, and beard. Nowadays it is decreed that women's hair should be long and that men's should be short; but even now men with long hair do not necessarily look effeminate, as is shown by the cowboys from the Wild West who have taken part in various exhibitions in 
this country, and whose hair reaches on to their shoulders. The shaving of the whole head is carried out by many savage nations, and this is perhaps surprising, seeing that the process cannot but be laborious and even painful when carried out with flint knives or pieces of shell. The Chinese leave the hair that grows from one small spot in order to make their pigtail, though, from what we hear, the custom is likely to die out.

In this country it might be thought that the tonsure of priests was the only remnant of shaving the head; but we need go no farther than the East End of London to find Jewesses who upon marriage shave their head and put on wigs. It appears that the custom is still universal in the remote villages of Russia, where every Jewess on her marriage shaves her head. The wig that is worn is of a very plain pattern, and the hair of which it is composed is parted down the middle. The object which seems to underlie the custom is the destruction of the charm of the women when once they have found husbands. In London the younger women do not seem to be keeping up the practice, and it is mostly in the case of those who are over forty years of age that shaved heads and wigs are to be found.

There may be, however, another explanation. In many countries where great value was attached to a profuse head of hair a variety of superstitions arose, and emblematic observances were followed with regard to it. Parents dedicated the hair of their infants to gods, as did young women theirs at their marriage, warriors after a successful campaign, and sailors after deliverance from a storm. The Egyptians of all classes, as well as their slaves, shaved their heads and wore wigs. By this habit they ensured greater cleanliness, and the structure of the wig not only allowed the heat from the head to escape, but protected the latter effectively from the sun.

It does not happen that both sexes always follow the practice of shaving their heads, for, contrary to what prevails 
amongst civilized nations, Fijian women are usually closely cropped, while the men spend much time and attention on cultivating and elaborately arranging a luxuriant mass of hair.

The tendency nowadays is to cultivate eyebrows and eyelashes, but if we go back in our history to the reign of Richard II we find that it was thought necessary to pull out the eyebrows, and at the present day in some parts of Africa it is one of the requirements of female beauty to eradicate the eyebrows. Special pincers for this purpose are to be found among the appliances of the native toilet. A man may of course remove all the hair, speaking in the ordinary way, from his face, or he may retain only his moustache or his whiskers or his beard, or a combination of any two of these. At the present day we meet with all sorts of styles, though one may be the fashion for the moment among the younger generation or those who wish to be considered smart. One cannot alter the disposition of one's hair as easily as one can change one's clothes, and this, perhaps, taken in conjunction with the objection to change on the part of a man and his relatives, gives the variety that has been mentioned. For instance, if it were customary when a man was young for his fellows to wear beards or only a moustache, then he continues to wear a beard or only a moustache.

Perhaps no other fashions come round again more regularly than those which govern the amount of hair on a man's face, and it may be interesting to indicate very briefly some of the changes which have taken place during the last two thousand years or so in this country.

The inhabitants of England at the time of the Roman invasion either did not shave at all or wore only a moustache. The Romans often cut their beards (see Plate VII, Figure F.), and the Saxons parted their beards into double locks'or neatly trimmed them. When the Normans came into this country they were closely shaved, but afterwards they went to the opposite extreme. 
In the fourteenth century old men wore beards and the younger generation shaved. Edward III had a long beard, Edward II two small tufts on his chin, and in Edward IV's time the beard was closely shaven. Afterwards we find that a tax was put on beards, and once more, in Elizabeth's and the following reigns, we have a number of extraordinary fashions in connection with the hair on the chin. When we get to I798, among the upper classes beards were again no longer worn, and there have been several changes since that time.

Apart from the prevailing fashion, there is, under the conditions which we have seen to govern the matter, considerable scope for the indulgence of individual taste, and often an effect is produced which is much more striking than otherwise would be the case. A man may choose, for instance, to grow a large pair of bushy whiskers, and he may thereby give character and importance to his face, which without them would be very insignificant. Curly hair is effective and has its advantages, therefore we find that it is carefully imitated both in the case of real hair and of wigs. The effect is now usually produced artificially only in connection with ladies' hair. When dealing with this branch of the subject once more, we might allude to the monstrous toilets which have been built up in defiance of all laws of proportion and, we might add, of comfort and cleanliness also.

To utilize the hair from the heads of others is an ancient practice still to be met with, and all sorts of means for making the most of one's own hair in the shape of pads and so on are still adopted.

When speaking of footmen, we shall find that those who dress in the costume that was in fashion when hair powder was in vogue still wear it, and the custom has been traced to the days of Rome, when gold dust was put upon the head. It has been suggested that our Saxon forerunners used coloured hair powder or else dyed their hair, but the evidence comes from Saxon drawings in which the hair is often painted blue, 
and this may be due merely to the caprice of the artist. It is well to be wary also in studying the colour of clothes at early periods, by looking at pictures, to remember that the illuminators may have followed their own fancy, and made garments of such colours as fitted in with their own ideas of ornament.

Though the use of wigs is extremely ancient, the origin, which is customarily ascribed to the peruke, is interesting. Many curious fashions have arisen through royal peculiarities or temporary indispositions, the courtiers having imitated their royal master or mistress, out of compliment. Louis XIV had, when a child, remarkably beautiful hair, which fell in curls on to his shoulders, and to imitate this, his courtiers put on false hair, while later in life the king himself adopted the fashion which they had set.

The obvious use of artificial additions to the hair has now been discontinued for very many years except in a few cases. Judges and barristers with a few Parliamentary and other officials still wear wigs, as do also certain coachmen and footmen, but these we shall consider elsewhere.

It will prove of no small interest after recalling the various modes of doing the hair which ladies have adopted during the last twenty or thirty years, to compare them with the fashions in Egypt in Roman times about two hundred years before the Christian era.

The reason why we can do this so well is that the RomanoEgyptians put on the top of their coffins a model of the head of the person who was buried in it. Professor Flinders Petrie has shown that the effigies were really portraits, and even a glance at some of them would go far to prove the statement. Professor Petrie made composite photographs of the face on the outside of the coffin and of the skull within, and both in the profile as well as in the full-face pictures it was seen that the plaster model clothed the skull, as it were, with flesh.

To return to the question of hair dressing, if one examines 

FIGURE A.

Figure C.

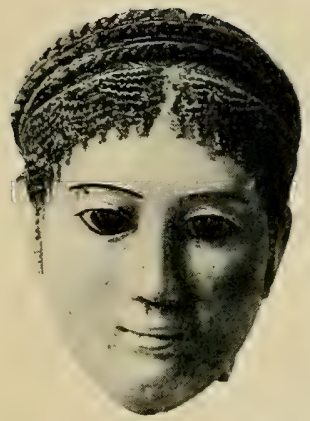

Figure E.

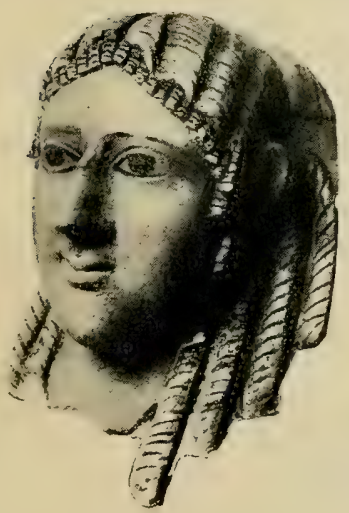

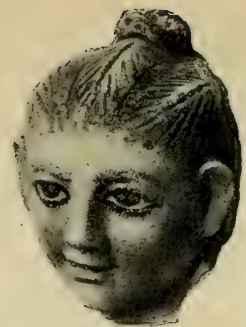

FIGỦRE $B$.

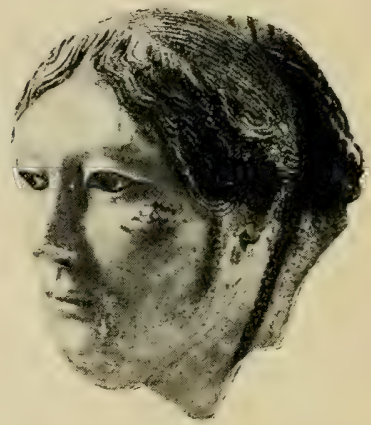

Figrike D

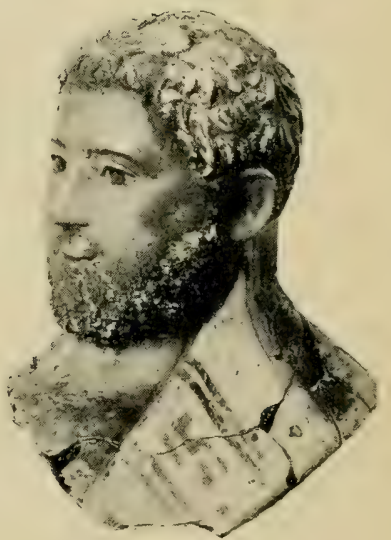

FIGURE F.

Methods of Hairdressing illustrated by Romano-Egyptian portrait models in the Myers Collection, Eton College. (See page 97.) 
Plate VII we shall see first of all a lady with corkscrew curls, which were more prevalent in the last century than they are now, though they have not yet died out. Then we have a lady with a very elaborate fringe, another who allows her hair to fall in waves on her forehead, and makes a chignon at the back, and lastly (Plate VII, Figure B) a little girl with a small bun on the top of her head. Another specimen, not figured here, and also contained in the celebrated Myers Collection, shows the bun exactly as it was worn at the end of the last century.

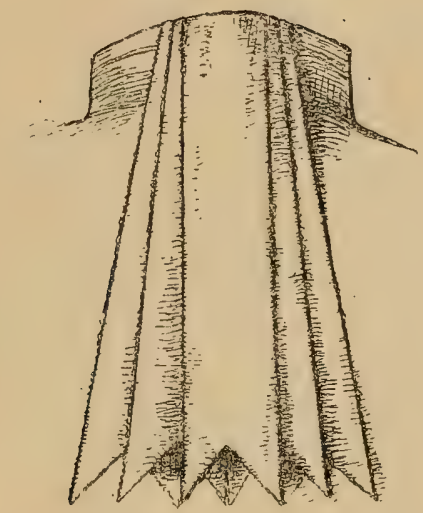

FIGURE IO9.-The "flash" of five black ribbons on the collar of the Welsh Fusiliers. A survival from the days of the pigtail.

We have included two heads (Plate VII, Figures A and F), one of a boy and the other of a man, showing the great likeness that exists between the way in which hair was done more than two thousand years ago and at the present day.

Besides the methods of hair arrangement which have survived or been revived, there are certain little features still to be seen here and there in modern dress which owe their origin to the ways in which hair or wigs were dressed.

A remnant of the bag-wig, with its great bow of black ribbon, we may find in the army. For a long time on the backs of the collars of the officers and staff-sergeants of the Welsh Fusiliers 
there have been fixed some ribbons which hang down their back. These, which are few in number, are called the "flash," and are said to represent the bow which used to ornament the bag-wig. A hundred years ago the officers of the regiment wore their hair turned up behind, and it was then tied with a bow. This is in keeping with another explanation which Mr. R. Simkin has given us, which is that the flash is the survival of a bunch of ribbons that were sewn on the back of the coat-collar to protect it from the pomatum and powder of the " clubbed " or "queued " hair. The privilege of wearing the "flash" has recently been extended to all ranks of the regiment (see Figure I09).

A survival of the same kind, which takes us back to the time of wigs, is to be seen on the backs of the collars of several court dresses, and it is known technically as the "wig-bag." It is also, as we have had occasion to mention, to be seen on the back of the collar of the liveries of some servants whose dress is in the old style, and here, as in the case of the Lord Mayor's coachman, it looks as if it had originated in a bow (see Figure II3). 


\section{XIV}

\section{SPECIAL DRESSES}

\section{FASHIONS KEPT UP BY CEREMONIES-SURVIVALS IN SPECIAL COSTUME-FLOWING GARMENTS}

$I^{N}$ the foregoing pages we have been concerned chiefly 1 with individual parts of costume, and, while showing how various garments have reached their present form, we have busied ourselves with discovering the origin of many important survivals. We have not however hesitated, in dealing with these details, to touch on all kinds of costumes, and here and there we have left civilians' dress for a moment to take an illustration from that of the soldier or the member of some other profession.

At the same time, we have indicated that on occasions of ceremony, whether religious or otherwise, the dress adopted is, as a rule, more primitive or older in style than that which is customarily worn. This is what might be expected, as, on the one hand, innate conservatism and objection to change come into play, and, on the other, ordinary everyday practical matters being for the time put on one side, it is possible to wear clothes which otherwise would be inconvenient and liable to get damaged.

When we ourselves dress for dinner we go back nearly a century, but nothing could be more primitive than the Court etiquette of certain tribes, ${ }^{16}$ where the subjects of the king may only approach him when entirely unclothed. Living- 
stone was received by the Queen of the Balonde Negroes in South Africa when she was in a state of complete nudity. The women of neighbouring tribes and members of other races, for instance those in Australia, entirely remove their clothing on festive occasions.

Among some black races, also, the girls who are sent as official messengers to important persons are not clothed. There are still certain tribes of "leaf wearers " in India, while at a yearly festival in Madras the whole low-caste population throw off their ordinary clothing and put on aprons of leafy twigs. Another case in point is that of the priests who conducted the sacrifices in ancient Italy and Greece, for they are often represented on monuments as being naked, while the rest of those present at the ceremony are fully clothed.

In taking up the question of ceremonial dress among civilized peoples, we find that we have a very wide field in which to wander. We have the Court, which might alone occupy our whole attention; we have naval, military, ecclesiastical, and legal dress, the garb of the universities, the costume of pantomime characters, of the acrobat, of the athlete, and the liveries of servants, besides the costumes adopted for special ceremonies and in connection with particular institutions. In treating of survivals in the case of the army, where the variety in uniform-if we may use this paradoxical expression-is so great, we may content ourselves with discussing matters in a way similar to that which we have adopted before. On the other hand, we may also describe and illustrate particular costumes, as a whole, while showing how far their history may carry us back.

In addition to the clothes actually worn by persons, there are those which are found on dolls. These may be on the representations of personages such as St. Nicholas, on the Continent and elsewhere, and they are interesting because in many cases they may show a national costume which is no longer worn. In the same way, puppets such as are used in 
the play which we know as Punch and Judy, and their dresses, like others which we have studied, may bring to our notice chapters of history in a way that is exceedingly attractive.

There is no doubt but that long flowing garments produce a more elegant effect, and give rise to a more stately appearance than those which are short or tight fitting. In the case of men, such garments would now be too much in the way on ordinary occasions, or when any physical exertion is required. The king and noblemen on state occasions wear robes, as do also the members of City companies and borough councillors when they assemble together. The case of the clergy will occur to everyone, and legal and academical dress may also be mentioned.

In the privacy of the home it is possible for every man to wear a dressing-gown, and pyjamas have not in all cases superseded the more primitive nightshirt. In the case of ladies, we find that they cling lovingly to long dresses, though, as we know, there is much effort being made to dispense with skirts under ordinary conditions, and the fact that short skirts have for some years been fashionable for outdoor use looks as if some progress were being made. 


\section{$\mathrm{XV}$}

\section{SERVANTS' DRESS}

THE PROTOTYPES OF LIVERIES-REMINISCENCES OF GEORGE II AND GEORGE III-ORIGIN OF THE PAGE-BOY'S BUTTONS -THE JOCKEY CAP-APRONS

IN taking up the question of special costumes, we may 1 perhaps begin with those which we see most commonly, and for that reason we may turn our attention, in the first place, to the liveries and dress of servants.

We have laid down a sort of rule that the costume of servants is that of the master of an earlier generation, and we will now bring forward some evidence in support of it.

Modern coachmen and outdoor footmen wear the tall hat, the bright buttons, doeskin breeches and the top boots characteristic of the outdoor and riding dress of the gentlemen at the beginning of the nineteenth century. The groom, it will be noticed (see Figure IIo), wears in addition a leather belt, and the reason for this will not perhaps strike the inquirer straight away. Our grandmothers and great-grandmothers did not always drive in carriages, and it was customary for them, when riding on horseback, to sit on a pillion behind a gentleman or a servant. The belt which we now see round the waist of a groom afforded a hold to which they had to cling, in order to prevent themselves from falling off the horse.

Such a livery as we have described is also adopted by the general run of well-to-do people. The aristocracy, however, 
are more inclined to stand upon ceremony, and through it to make more show. Their footmen, who go by the generic name of "Jeames," wear plush breeches, silk stockings, and powdered hair. (See Figure III.)

A little inquiry will soon show that these peculiarities of dress were those which it pleased the gentlemen of George III's time to adopt. Some flunkeys belonging to the nobility have their breasts ornamented with cords known as aiguillettes, and these give them somewhat of a military appearance, besides reminding us of the old retainers. The coats that go with the plush breeches and are cut away so as to recall the wings of a pigeon-hence the name "pouter" coat-are a special feature of George III's reign. The coachman's coat is usually a little fuller in the skirt, and carries us back to the time of George II. In another clung when riding on a way this costume is a little older in

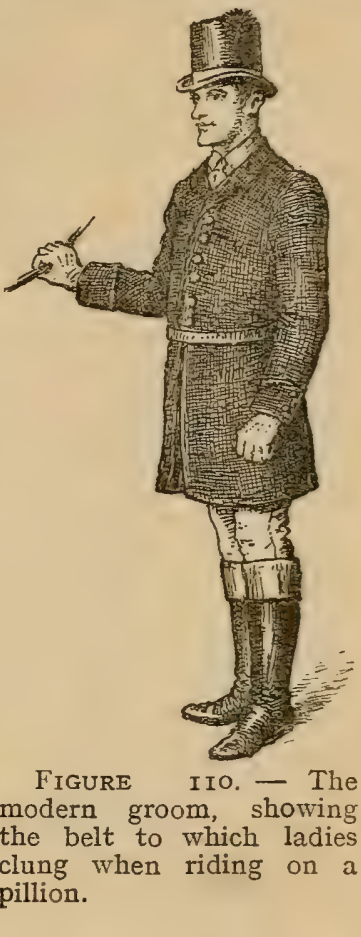
its style than that of the footman who powders his own hair instead of wearing a wig like his colleague. (See Figure II2.)

In connection with the Lord Mayor more ceremony still is maintained. His coachmen and footmen appear in all the glory of three-cornered hats, which are decorated with feathers, and their coats are highly ornamented. They are representatives of the very fine gentlemen of George III's time.

On the back of the collar of the Lord Mayor's coachman, we find an arrangement that looks like an elaborately made rosette of black ribbon (see Figure II3). This is a survival of the bag-wig, of which we shall have occasion to speak again 
when dealing with Court and military dress, so that we need not go into further details here with regard to this curious vestige. (See page I7o, Figure I43.)

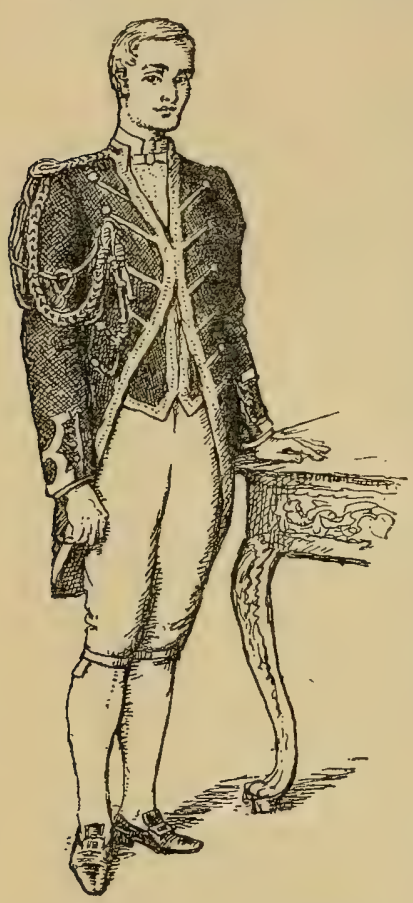

FIGURE III.-A footman in plush breeches and with powdered hair. His "pouter" coat dates from the reign of George III. (By the courtesy of Messrs. F. T. Prewett and Co.) these same garments were adorned with brass buttons bearing the initials of the firm that provided the dinner. Inquiry soon elicted the fact that the men carried with them small brass cases which were sprung on to their ordinary buttons, and at once gave them the appearance of being on the staff, and showed that they were waiters.

The almost overwhelming number of buttons which are 
worn by page-boys must have been a source of wonder to many. They run from neck to waist of a tight-fitting jacket in such a crowded line that the pages usually go by the name of "Buttons." Occasionally we see the livery ornamented by two other rows of buttons which are useless, and run from the shoulder towards the waist (see Figure II4) in a way similar to those on the coats of His Majesty's postilions, the derivation of which from a uniform we have already described (see page 27). On looking at an old book ${ }^{17}$ of fashions we find that a costume called the "Dutch Skeleton Dress" was very fashionable for young boys in I826 (see Figure II5). In this we find that there were brass buttons arranged in three rows, similar to those we have just described. It is difficult even in the modern page-boy's dress to see the lower edge of his coat, but in the case of the small boy of 1826 it was impossible, because his trousers were buttoned on to the outside of it.

The name of the skeleton dress is interesting, because it points to the buttons marking out the position of the breast bone, and it recalls the story that the lacing on the breast of Hussars, which we have interpreted as representing enlarged buttonholes, was intended to give the appearance of ribs. This would be in keeping with the figure of a skull that was worn by some of them on their head-dress. We may imagine that in the page-boys, with the superabundance of buttons in one row, that the other two series have migrated and joined with those which originally

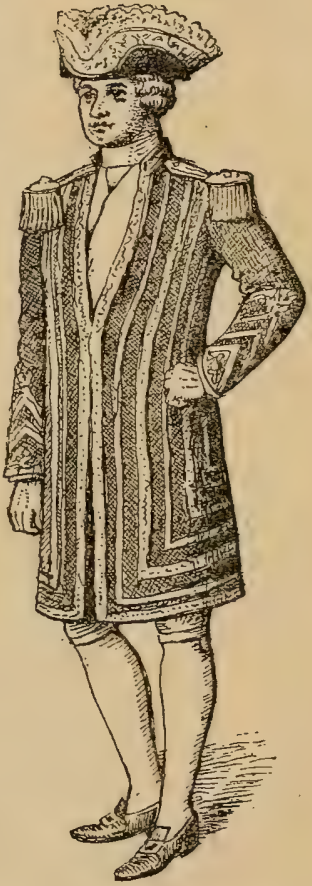

FIGURE II2. - A sheriff's coachman with the full-skirted coat of the time of George II. (By the courtesy of Messrs. F. T. Prewett and Co.) 
fastened the coat. It is interesting to note that one of Queen Victoria's dolls wore the Dutch skeleton dress.

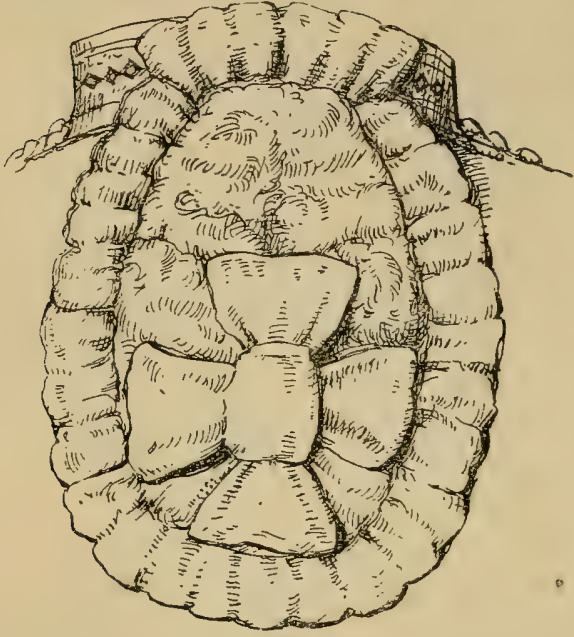

FIGURE II3.-The wig-bag (a survival of the bag-wig) now seen on the back of the collar of the Lord Mayor's coachman.

On special occasions, such as weddings and coronations, the nobility and members of old families dress their servants in state liveries, and some very interesting costumes appear for the time. For instance, at the wedding of the Duke of Norfolk in I877. some of the coachmen and footmen appeared wearing on the shoulder of their state livery a "manche" or large hanging sleeve, which is familiar to students of heraldry and may be the origin of the inn sign usually called the " Crooked Billet."

An interesting little survival is sometimes seen on livery collars. It is a little patch of lace, and is an imitation of the knotched buttonhole or laced hole which was commonly made on elaborate dresses.

We get a survival of a livery cap, which was worn by servants generally in the middle of the eighteenth century, in the black cap worn by the drum-major of the Foot Guards and the bands of the Household Cavalry. The servants at Trinity College, Dublin, use the same head-dress, and it may be mentioned that their name "skip" is an English one in use in the time of Elizabeth. We find that the black cap is also adopted by huntsmen and postilions (see Figure 89), while jockey caps are of a similar-shape.

The costume of jockeys is an instance of parti-coloured 
dress which, apart from the Stage, is now chiefly worn in connection with sports such as football and racing. Some parti-coloured garments made their appearance early in English history, as we shall see when dealing with the subject of patterns.

The cockade is now a particular feature of the liveried servant, and as the story of its evolution is of a particularly striking nature, we will consider it in a special chapter.

Here and there we find survivals of the old beadle, with his three-cornered hat and his long gown with its curious capes and its bright edging. To find the original wearer of such garments we shall have to look about at the end of the seventeenth century. The watch then wore very large coats with many

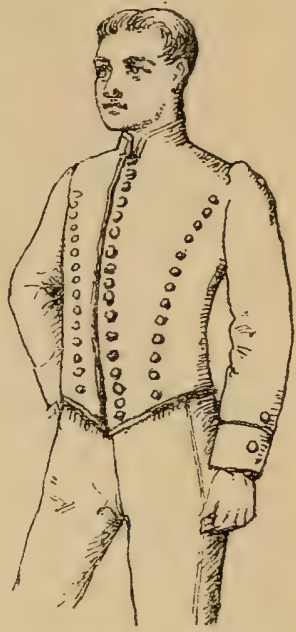

FIgURE II $4 .-\mathrm{A}$ modern page-boy's livery.

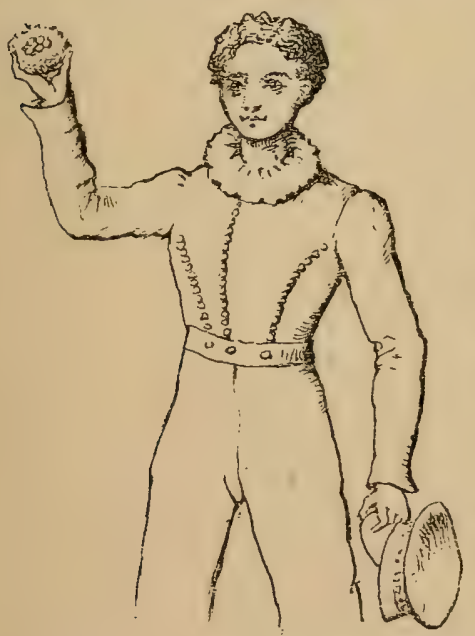

Figure 115 - The Dutch skeleton dress, fashionable for boys in 1826 . capes, and from these was developed that of the beadle. No doubt colours and other ornamentation were produced so as to bring the dress of the beadle, more into the line with liveries and to give him a more ornamental and imposing appearance.

We might also mention that the beadle, to whom we shall once more allude, still makes his appearance and plays his part in the Punch and Judy show.

When we recall the many and varied liveries which the 
porters belonging to the various places of amusement and business establishments now wear, we cannot help drawing attention to the magnitude of the problem which would confront anyone who desired to trace the origin of their clothes. In one detail or another we see the remains of an old livery, while turning from these we find a gaily coloured plastron borrowed from a Hussar uniform, and besides the cap there are a host of other features which have been taken from military and civilian dress.

Railway porters if not menials are the servants of the companies which employ them, and there is one feature of their dress which is worthy of note. It will be seen that their waistcoats, although generally built on the same plan as that of the ordinary individual and having a linen back, are provided with sleeves. It is truly a coat which comes to the waist, such as we shall speak of when dealing with the dress of the Guards and other regiments, and it is usually the outermost garment of the porter.

If we now turn to the costume of the gentleman, we shall find a very good instance of what Mr. Paley Baildon claims to be done whenever a new garment is adopted. He says that it is always put on over all the others. In the case of the ordinary civilian we have the waistcoat, which was originally an outer garment. Then comes the frock-coat or surtout, which at the beginning of the nineteenth century was an overcoat, and over this again in cold weather the modern ulster or top-coat is put.

No consideration of servants' dress would be complete without an allusion to the cap and apron of the house- or parlour-maid. To begin with, we see in these a survival of the special dresses which were once adopted by particular trades. The fact that the cap is white points to a connection with the early head-dresses of women which we see now perpetuated by the nuns, and which are relics of the time when it was customary to have linen caps and hoods. 
Perhaps there is some connection between the cap of the servant and the custom which condemns women to wear their hats in church and makes them feel desirous of keeing them on their heads at all kinds of public entertainments. On this question, however, we shall have a word to say later.

Sometimes servants' caps have strings which, like those which are customarily found on bonnets and on mitres (see page 4I), are the survival of the ends of a head fillet. A development in this direction was a scarf which a year or two ago was allowed to hang down from the backs of ladies' hats, and was often of so substantial a nature that it looked very much like a fringed towel.

The apron can claim a long history, and just as the plush and powder of the footman were once worn by his master, so we may easily discover that the apron was not always the special attribute of those who work or serve. Towards the end of the seventeenth century aprons were considered an almost essential part of a fine lady's costume. A little later on, Queen Anne made and wore them herself, and very gaily ornamented garments they were.

In the case of the lower classes, aprons were-as they still often are-provided with bibs. The old name for them was barme-cloth, and under this title Chaucer refers to the apron of Carpenter's wife as being as white as the morning milk. Unless the article of dress which we are discussing was of considerable age, we should hardly have the proverbial expression which defines a man who is always at home as being tied to his wife's apron-strings.

Another name for an apron with a bib which was pinned to the front of the dress was "pinner." This gives us the word pinafore, which refers now to a kind of overall rather than to an apron.

In the costumes of the barge-women and milk-women, where we get a slight survival of characteristic country dress, we have 
seen that in both cases the apron is always adopted as part of the outfit. (See Plate VIII.)

The uniform of the hospital nurse partakes somewhat of that of the nun, but at the same time the apron is often one of its most important features. We mention this uniform here because it has become customary of recent years for the nurses who look after the children of well-to-do families to assume the bonnet and veil and severely cut collars and cuffs of the hospital nurse.

Here again we get a case on all fours with the adoption of evening dress by waiters, and the gradual assumption by the lower classes of the dress of their social superiors. 


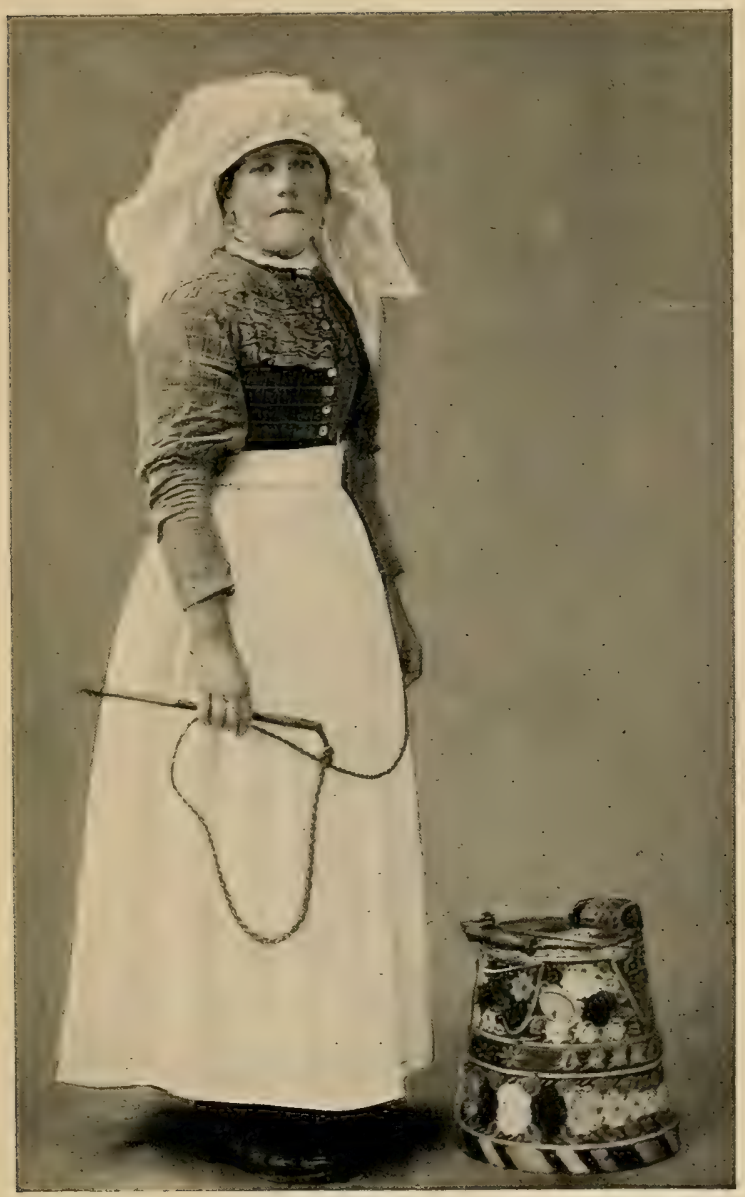

A BARGE GIRI. WITH THE CHARACTERISTIC BONNET AND APRON. SHE IS NOT WEARING HER SMALL PLAID SHAIVL. (See page I Io.)

(From a photograph by Wakefield, Brentford.) 



\section{COCKADES}

THE COCKADE A DEGENERATED CHAPERON-THE VARIETIES OF THE COCKADE-COCKADE WEARERS

THE cockade as we know it (see Figure II6) is now com1 monly worn by servants, but, like their clothes generally, it was once used by their masters. The books of an oldestablished firm of hat manufacturers show that as late as I 789 cockades were worn by gentlemen themselves. Apparently, in the beginning, the sporting of a black cockade meant allegiance to the House of Hanover. Now the use of the ornaments is supposed to be confined to the servants of Royalty and of those in the Royal service, though this does not seem to be actually the case. In a letter to The Morning Post ${ }^{18}$ Messrs. André and Co. say that "the practice has long been regarded as a convenient and fitting sign of social distinction, and that only such persons should assume the cockade as enjoy hereditary rank or else some position of importance in the State, including all officers, military and civil." Yet they can find no trace of the question even having been

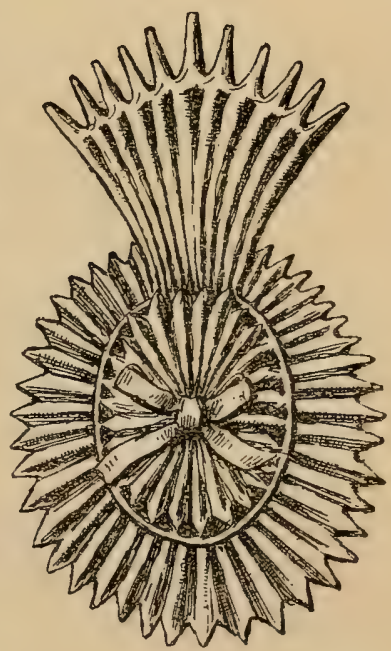

FIGURE Ir6. - The cockade, known as the "large treble," representing a survival of the chaperon' 
dealt with by any authority, nor have the classes of persons privileged to display the cockade been at any time accurately defined.

Sir Alfred Scott Gatty, Garter King-at-Arms, points out

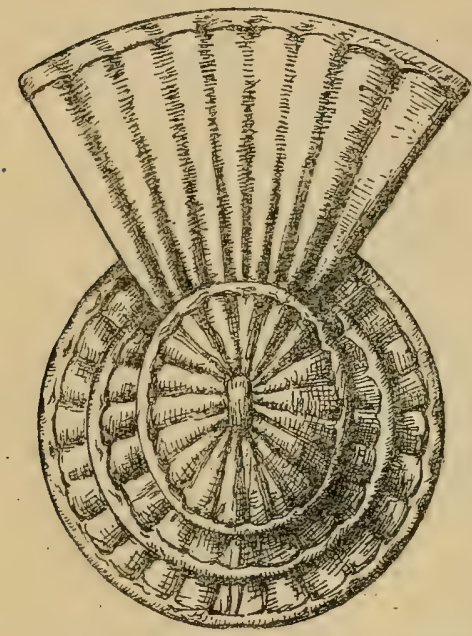

FIGURE II7. - A "treble cockade" covered with black cloth for mourning. The concentric circles may represent the twisted liripipe of the chaperon. that the matter is really outside the College of Arms, and it does not come under the jurisdiction of the Lord Chamberlain's department, which usually arranges all matters connected with official dress.

Before, however, we touch on the various kinds of cockades, and mention those by whom the different types are at present worn, it will be well to deal with the construction and evolution of the cockade, and we shall be able to show that it has considerable claims to be considered something more than a mere conventional rosette. As regards actual material, the basis of the cockade consists of leather, which is japanned, while a certain amount of ribbon may also be used. In the case of mourning, we find that the cockade should properly be covered with black cloth (see Figure II 7 ), but nowadays a piece of crape is often twisted round the one generally worn. The ribbon is usually merely a small bow tied in the middle of the rosette (see Figure II6), but the centre of the latter may be covered with ribbon and the bow replaced by a button.

The cockades worn by the Royal servants on the front of their three-cornered hats on state occasions (see Figure I20) are large. The rosette has points, while the upper part, or 
fan, shows them in profusion, and there is no silk bow. The Royal cockade for semi-state has a simple fan, while that worn on the silk hat at ordinary times (see Figure I2I) has no fan,

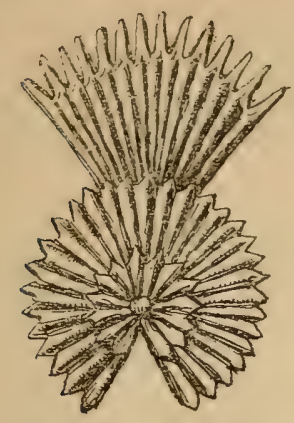

FIGURE i 18 .-Treble cockade used by Chelsea pensioners.

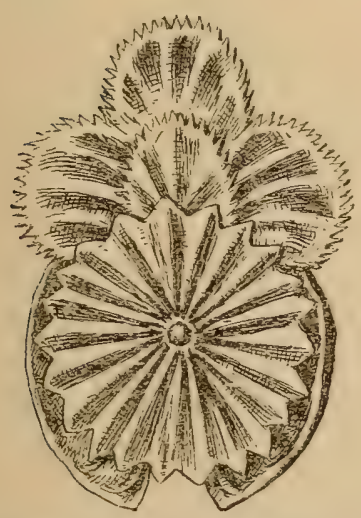

Figure 120.-Royal cockade for state occasions.

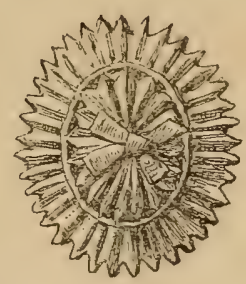

FIGURE II9.-The regent cockade.

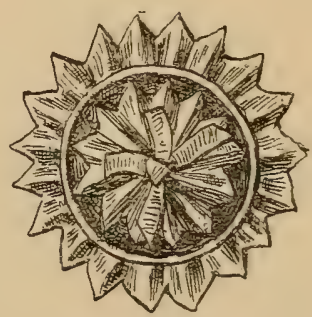

FIguRE I2I.-Ordinary Royal cockade.

but the edges are cut into points and there is a bow of ribbon in the centre.

The ordinary fan cockade is used in various sizes, and is shown in Figure II6. This is called the "treble," and has a bow of ribbon as a rule. A curious variety worn by the Chelsea Pensioners has no ribbon, while a segment is cut from 
the lower part of the rosette (see Figure II8). The only other variety with regard to shape that we have now to mention is the "regent" cockade, which is exactly like the treble, but without the fan. (See Figure II9.)

It has been suggested that the cockade can lay claim to have been descended from a very ancient and curious form of headdress, and Mr. Calthrop ${ }^{19}$ has traced in a very interesting way
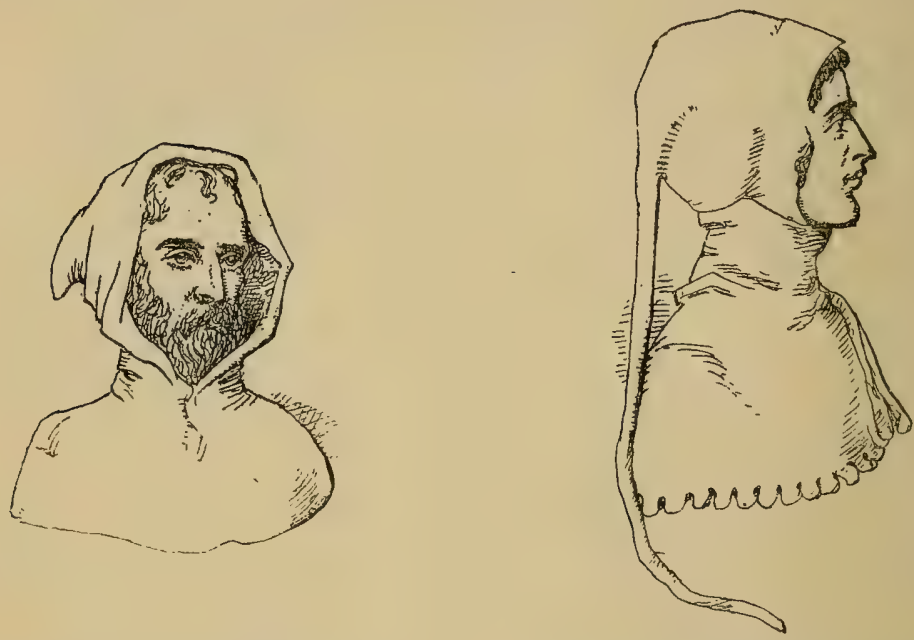

Two stages in the evolution of the chaperon.

FIGURE 122.-Combined hood and cape.

FIGURE 123.- Enlargement of the peak of the hood to form the liripipe.

(After Calthrop, by kind permission of Messrs. A. and C. Black.)

the development of this, as well as of the cockade which may be a survival of it in miniature. The head-dress in question was called a chaperon, and came into favour in the time of Richard II. It was itself derived from a hood and a cape which were originally worn separately, but afterwards the two were joined together for convenience, so that they could both be donned at the same time. Fashion lengthened out the peak of the hood extravagantly until it reached nearly to the ground, and then the prolongation was called a liripipe. 
Next, possibly owing to the freak of some drunken blade, it was ordained that the whole arrangement should be twisted up round the head, so that what was in the beginning a cape with jagged edges stuck out on one side like a cock's comb. In this way we get our word cock's-comb, meaning a dandy. (See Figures I22-5.)
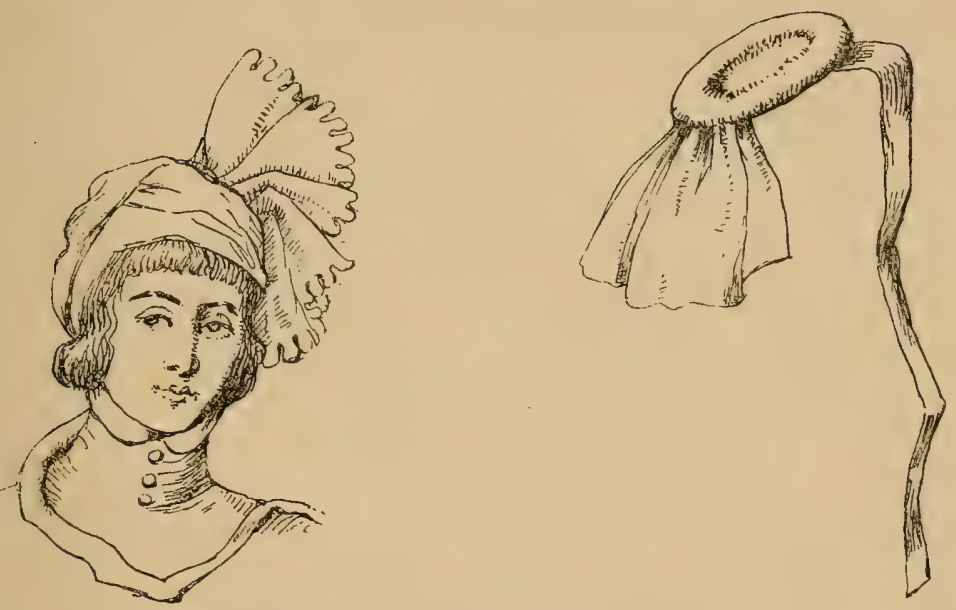

Further development of the chaperon.

FIGURE I24-Cape and liripipe made into a head-dress that can be altered at will.
FIGURE 125.-A chaperon save trouble.

(After Calthrop, by kind permission of Messrs. A. and C. Black.)

It will be noticed that the modern cockade shows the jagged edges sticking up, and it would appear that the rosette represents a coiled-up liripipe. Even to-day cockades are of various colours, and, as Mr. Calthrop points out, the servant's chaperon from which it was derived used to bear the colours of the master's livery. The chaperon is also to be seen on the robes of the Knights of the Garter at the present day, where it is fixed on the right shoulder as a kind of cape. (See Figure I44.) Mr. Calthrop also points out that the present head-dress of the French lawyer is another descendant of the 
chaperon, and that the buttons worn by the members of the Legion of Honour and other foreign Orders are connected with the same idea.

A writer in The Sketch ${ }^{20}$ sees in the rosette and fan of the treble cockade the remnants of the crown and star which we find on military uniforms. He says that the earlier forms seem to have been made of metal, which must surely be a mistake, though the cock of the hat was, as we know, sometimes fastened up with a brooch. The example which he figures, however, and uses in support of his theory, is evidently a helmet plate which displays the star, garter, and St. George's Cross, the whole being surmounted by a crown, and in the cockade he claims to see all these elements in a modified condition. If this derivation of the cockade were correct, it would be in keeping with the quotation which the same writer gives from Cussan's "Handbook of Heraldry," that the privilege of wearing a cockade is confined to the servants of officers in the King's service, or those who by courtesy may be regarded as such. The theory is that the servant is a private soldier who when not wearing his uniform retains this badge as a mark of his profession. We cannot help thinking that Mr. Calthrop's derivation of the cockade is more feasible, though it is not easy to see the remains of the coiled-up liripipe of the chaperon in the way which Mr. Calthrop represents it in his sketch. ${ }^{21}$ In the majority of the cockades there is no trace of a spiral such as he indicates in his figure, though in the mourning cockade concentric rings are very clearly shown. A word may now be said as to those whose coachmen and footmen wear cockades.

The Royal cockade is used by the servants of the King, and by those belonging to members of the Royal Household. It is large and circular, as we have seen, and half the disk projects above the top of the hat. The regent cockade, which has no fan, is worn by the servants of naval officers, and no part of it is allowed to project above the hat. The servants 
of the officers in the Army, Yeomanry, and Territorials wear the treble cockade with the fan, as do also those of the Lords Lieutenant and their deputies, as well as of the members of the Diplomatic Corps. Besides this, it appears that the same kind of cockade is worn by the servants of the following :all peers and their sons and daughters, baronets, knights, and sheriffs, judges, justices, and magistrates; members and high officers of Parliament and of the Civil Service ; dignitaries of the Church, King's Counsel, and law officers of the Crown.

English ambassadors have the fan painted with three stripes of red, white, and blue, and while the edge of the rosette is red, the next part is white, and the centre blue. In this case also the ribbon in the centre shows the same three colours. The cockade of the Danish ambassador is of ordinary black leather, but the centre is covered with a rosette of ribbon, red at the edge, with a circle of white next to it, and green in the centre, while the whole is finished off with an ornamental black button or knob. Other foreign ambassadors have their cockades coloured upon the same principle as the English; but in some the colours are shown on the fan in bands instead of in stripes, and the centre of the rosette may have segments of different colours instead of rings. In the case of the French ambassador the colours on the fan are in stripes, while those of the rosette are in segments.

Of recent years cockades have been reduced in size until they have become mere pigmies in connection with the uniform of " chauffeurs," or motor-car drivers. The latter customarily wear a military kind of hat with a mushroom top, and as a cockade fastened on the side of one of these would not look elegant, a very small cockade is now made and fixed in the front of the cap just above the peak. Would not one of the wearers of the old cock's-comb turbans be amazed if he could see the most recent outcome of his head-dress in its modern surroundings?

There seems to be little doubt but that the "cockade" 
forms part of the livery of many who have no recognized right to it. Perhaps the ease with which it can be assumed is shown by the price-lists of jobmasters, in which we find, after the charge for the hire of broughams and victorias, a footnote to the effect that cockades are " $6 \mathrm{~d}$. extra if required." 


\section{XVII}

\section{CHILDREN'S DRESS}

SURVIVALS IN CHILDREN'S DRESS-SPECIAL SCHOOL COSTUMESTHE BLUE-COAT BOY-PUBLIC SCHOOL BOYS-ADOPTION OF A SPECIAL DRESS AT GIRLS' SCHOOLS

CHILDREN'S costume, though characteristic, is in some instances connected with ceremonies, and in others with particular institutions ; it may therefore with advantage be considered at this point.

We find that for very many centuries in this country, children, except when small babies and in their early years, were dressed practically in the same way as their parents, and looked like men and women in miniature.

The ludicrous effect that was sometimes produced is well seen in Hogarth's engravings, which date from the time when infants were powdered and patched as well as dressed in a way that made them truly grotesque.

A relic of this custom is still to be seen in certain costumes which it is now fashionable for children to wear. Possibly the sailor's suit takes the most prominent place, and the Highland dress is also a favourite. It is perhaps not very strange that we do not see little boys going about in the uniform of policemen, and, until the South African war occupied the attention of this country, boys were seldom if ever seriously dressed as soldiers, but-during the struggle to which allusion has been made it was not an uncommon sight to see small boys in the khaki uniform and slouch hats which were adopted 
by the troops in Africa. Now, of course, the knickerbockers of the small boy, and the short skirts of his little sisters, though not absolutely characteristic of extreme youth, are recognized features of children's costume.

Mrs. Charles Ashdown, in her book on "British Costume during Nineteen Centuries" (I9IO), has pointed out that some of the children's dresses of the lower classes at the present day show traces of the Cromwellian style.

As regards small infants, it is still customary for some time after they are born to wrap more or less of a bandage round them in order to protect their tender bodies from injury. The modern "binder" is, of course, a relic of swaddling clothes, or those which consisted of a profusion of bandages. These still survive in the Holy Land. It may here be said that we meet in the word " pupa," which is the scientific term that we apply to a chrysalis, with the old Greek name for a baby in swaddling clothes. It is used now because the wings and legs of the future flying insect are hidden in something the same way as arè the legs and arms of the much trussed-up baby. From the same word we get the name "puppet" and the French word "poupée," meaning a doll. At the Hungarian Exhibition held in London some years ago a number of children's dolls were shown, which were dressed in swaddling clothes, which no doubt is an advantage, as no limbs need be made, and there are none to be broken.

In Roman Catholic churches at the time of baptism it is still the custom to place on the head of the baby a white cloth. It is now too small to cover the body, and it is called the chrysome, or chrism cloth, and with it once the newly-baptized infant was swathed. This was worn for a month by the child, and if the latter died within that time the cloth was used as a shroud. The chrysome is really the remains of a series of vestments which in the sixth or seventh century were worn by the newly baptized. The most important part of the costume was the albe, which was probably similar to that 
worn by the clergy, and a chaplet of flowers was also used to crown the child after baptism.

There are in this country still a few monumental brasses called chrysom brasses showing babies in their baptismal robes. A case where the child is swathed up even more rigidly than was customary in the old world is to be seen in the case of the North American Indian papoose, which is fastened down to a cradle of board or basket work, and at first is so fixed by the swaddling process that only its head is movable. In some instances several months elapse before even the arms are allowed to be free, and these are fastened up again at night.

It is probably owing to deformities that were at first accidentally caused by this bandaging process, that the fashions arose which demand that the shape of the skull in certain races shall be intentionally and artificially altered. To this subject, however, we shall refer again when dealing with the question of the effects of clothes upon the body.

As might well be imagined, the petticoats of small boys are a survival, and one which is to be commended in every way. The putting of infants at an early age into jersey knickerbocker suits cannot but be bad for them physically, and it makes them look for all the world like little woollen monkeys. Mr. Druitt ${ }^{22}$ has described as many as seven brasses of various dates between the years 1585 and I642, which show boys dressed in petticoats.

Dr. Alice Vickery thinks that it would be well if infant boys and girls were dressed exactly alike, say up to the age of five or seven. She says it is difficult to judge the extent to which sex bias is imbibed in the earliest years, and we should do our best to postpone it as long as possible. She continues ${ }^{23}$ :"If boys and girls were dressed alike, taught together and played together, this would do much to direct attention away from, instead of towards, sex distinction. The longer such a system could be maintained the longer would be the period 
during which rewards and punishments, praise and blame, would attach to actions and conduct, to the exercise of selfcontrol, kindliness and generosity, efficiency, industry and alertness, quite apart from all intrusions of sex idea, and its possibilities of subjection and predominance. That would in itself be a great gain.

"The best school for the training of life and conduct is the school of equality, where privilege and subjection are alike unknown, and the co-education of the sexes is a step in the direction of justice and fraternity.

"There is one point more on which I will add a few words. I have always been a great sceptic as to the essential physical inferiority of the feminine. It is true that in the aggregate that inferiority does exist, but where can we find a place, a people among whom the development of girlhood has had full and free scope?"

The custom for young girls to wear their hair down is also an old one, though married ladies of the fifteenth century are occasionally represented with flowing tresses.

At the present day, as a rule, when a girl puts up her hair her petticoats are usually lengthened simultaneously. The age at which these important changes are made varies. For instance, if a girl has a number of unmarried sisters older thar herself, the time is often put off. Sometimes the term " oldfashioned " is synonymous with "sensible," and people with such ideas very often keep their girls in short frocks until they are really grown up.

The two changes in the girls' method of dressing are not, however, always made at the same time. In the upper classes we find a tendency for the long dress to come first. Girls, on the other hand, who have to go out into the world as nursemaids and kitchenmaids, may, in order to make themselves look older and more sedate, put up their hair while they are still in short frocks, though it must be said that the effect is not quite pleasing if it is business-like. 



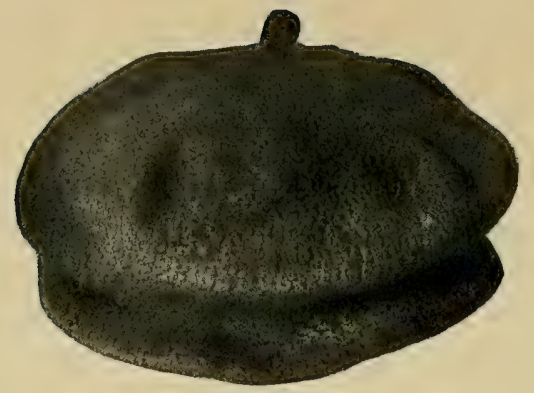

Figure A.

THE CAP WORN BY THE SCHOLARS OF CHRIST'S HosPITAL UNTIL THT MIDDLE OF THE NINETEENTH CENTURY.

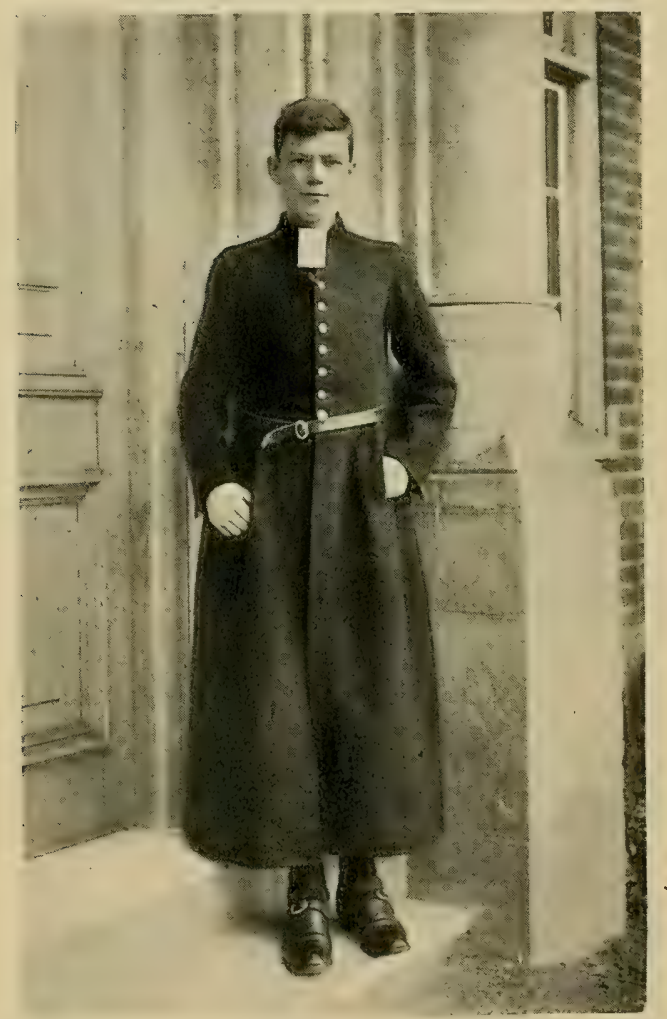

Figure B.

A scholar of Christ's Hospital. (See page I23.) (By the courtesy of the Rev. A. W. Upcott, M. A., Headmaster of Christ's Hospital.) 
In the bib of the infant we find a relative of that part of the apron or the more voluminous pinafore which covers the chest. Although grown-up women sometimes wear pinafores, these, like the bibs, must now be considered as part of children's dress, though no doubt in the beginning they were derived from the costume of grown-up people.

The next subject that we may appropriately consider here is that of the characteristic costumes which are worn in certain schools. In connection with boys, the first case which immediately comes to mind is that of the Blue-coat boys, as the scholars of Christ's Hospital, which was founded in I552, have come to be called. Their blue coat is part of the ordinary dress of the citizen of the reign of Edward VI, and the scholarly man at this time had the skirts of his blue coat long, while in other cases they were cut off at the knee. Instead of trunks, however, the Blue-coat boy wears more modern knickerbockers, but he clings to his yellow stockings. (See Plate IX, Figure B.)

The scholars of Christ's Hospital have discarded caps (see Plate IX, Figure A), but the one which should go with their dress is flat, like the one which came into fashion in the reign just mentioned. The latter was afterwards called the statute cap, when Elizabeth for the good of trade ordered that "one cap of wool, knitted thick and dressed in England," was to be worn " by all over six years of age except such persons as had twenty marks a year in land and their heirs and such as have borne office of worship." A cap of the same kind was worn by Edward VI, and is still part of the dress of Beef-eaters at the Tower of London as well as of the scholars in several Bluecoat schools in the country.

The blue coat afterwards came to be the ordinary livery of serving-men in the sixteenth and early part of the seventeenth centuries, and blue is still a popular colour for coachmen's liveries at the present day ; it has to a large extent been superseded by red in the army, but it has been generally adopted by the police. 
In a similar way we find that certain schools are called grey-coat or green-coat schools, and we have blue schoolsfor instance, one for boys and another for girls at Wells.

Then there is the Red Maid School, which was established in 1627 at Bristol, and in accordance with the founder's will the girls are dressed in red frocks, with white aprons and tippets and plain straw bonnets, trimmed with blue ribbon. In connection with this foundation it may be said that $£ 50$ is set on one side each year for the award of marriage portions to girls who have left the school.

Our public schools afford us very interesting cases of special dresses. Perhaps no other coat which a boy wears is so well known as the Eton jacket. This is accompanied by a tall silk hat.

King's scholars who are on the foundation and live "in College" also wear an academical gown of fairly ample proportions. The Eton jacket was not always black, and originally the head-dress was a mortar-board, and there was a broad lace collar or bands round the neck (see page 35). The black coats and top hats were introduced in I820 as mourning for King George III, and have been worn ever since. The broad collar which takes its name from Eton is probably a survival of lace bands, and is worn over the jacket in the same way.

Very similar coats are also worn by the younger boys at Westminster and at Harrow. In the latter case the jacket finishes off in a small point at the back, whereas the jacket worn at Eton is cut straight. The older boys at Eton wear a morning coat, a stick-up collar, and a white tie. This white tie is also worn by the masters, whether they be clerks in holy orders or not, and it seems to be a survival of a white choker which was wound round and round the stick-up collar, though, on the other hand, it may represent academical bands.

At Winchester the scholars wear bands, and this is no doubt connected with the use of academical dress, for it is usual 
for the boys on the foundation of public schools, as we have seen to be the case at Eton, to wear gowns.

The upper boys at Harrow, on the other hand, wear dresscoats with swallow tails; but should, however, a lower boy outgrow his short jacket, he is given what are called "charity" tails.

When speeches are made at Eton, those who take part in the performance wear dress-coats, knee-breeches, silk stockings, and buckled shoes.

Some costumes have probably been in existence since the foundation and endowment of the schools, and we can find parallel cases in the dress of some almshouses and hospitals for pensioners. Probably the idea originally underlying the wearing of a special dress is the same as is to be seen in modern charity schools, where all the boys or girls are dressed alike. It must simplify the tailoring and dressmaking arrangements, but at the same time it intentionally or unintentionally brands the children. Nevertheless, we see that the boys at most aristocratic and celebrated schools are in very much the same kind of boat.

To return to Eton again, we might mention one or two fashions in the ordinary dress which are curious. It is ordained that the lowest button of the waistcoat should be left unbuttoned and the bottom of the trousers should be turned up while it is part of the performance to thrust the hands deeply into the trouser pockets. If a boy elects to wear an overcoat, and he does not occupy a certain definite position or status in the school, public opinion forces him to keep the collar of his top coat turned up. Of course, schools generally, and sometimes the various houses in important schools, make a particular point of school or house colours.

At Eton, on the Fourth of June (which commemorates the birthday of George III.), in connection with the boating, there are interesting ornamentations added to the straw hats in the shape of flowers, and three boys who act as coxswains of the 
highest boats wear the uniform of an admiral and carry bouquets, while those of the lower eight-oared boats are dressed as midshipmen.

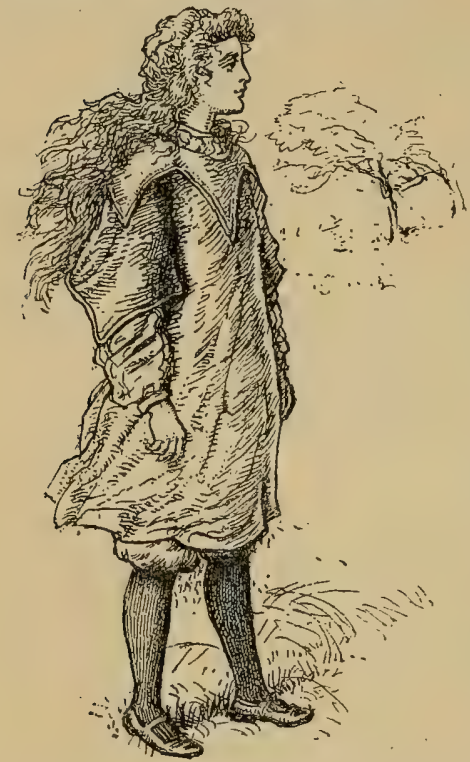

FIGURE 126.-Dress worn by the girls at Coombe Hill School. It is a modification of the Dervish Djibah.

The ceremony known as the Eton Montem, which consisted of a procession to a little hill near Slough, when many old and interesting costumes were worn, came to an end in the early years of Queen Victoria's reign (I845), and its immediate object was the collecting of money with which to send the head boy of the year to the University. It seems, however, to have originated in a piece of folk-lore, probably connected with the old tree worship, but sanctioned by the early Christian authorities as a semi-religious function. It is possible that the flowers seen in the hats on the Fourth of June may have something to do with the green branches and garlands that were once brought back each year from the Montem expedition.

When dealing with children's dress we ought not to forget the special costumes that have been adopted in some private girls' schools, nor how much is being done in them towards disseminating ideas on the subject of dress reform. For, after all, it is to the women of the future that we must look if any alteration is to be generally made. The introduction of exercises in the gymnasium has necessitated the adoption of a drilling dress in very many cases, but there are schools where such a costume is generally worn at all times, and others 
where it forms the working dress, while long skirts are only put on when no active exertion is expected.

At Coombe Hill School, King's Langley Priory, the dress takes the form of a tunic with wide sleeves which come to the elbow (see Figure I26). It is put over the head and has no fastenings. It is modelled upon the Djibah of the Dervishes, and is made of soft woollen material of a fawn colour. The yoke is of green embroidery and the underslip is tussore. Under the tunic a blouse of white silk is worn, and the sleeves, of course, show from the elbow downwards. The rest of the costume consists of cloth knickerbockers and stockings, with sandals or shoes that are made to the shape of the foot. This dress is worn on all occasions at school, and the girls are very proud of it.

At the Croft School, Fleet, in school and when any basketmaking, book-binding, drilling, or Morris-dancing is going on, a special costume is brought into use. In this case it consists of a tunic without sleeves, of red material with a velvet yoke, and shoulder straps (see Figure I27). As a finishing touch there is a girdle tied loosely in a bow. It is not placed round the waist proper, but drops towards the left knee as did the sword-belts which the knights in olden times wore over their armour. A white silk blouse shows above the yoke round the neck and has full sleeves. The knickerbockers in this case are made of red knitted stockinette instead of cloth. The costume is a

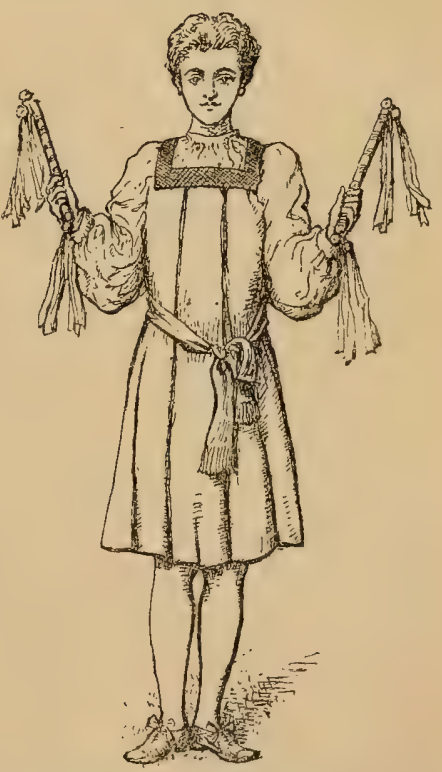

FIGURE 127.-Dress worn by the girls at the Croft School, 
modification of that used in Physical Training Colleges, where the tunic, however, does not reach to the knee. Miss Hodgson, the principal of the Croft School, has an interesting doll which is dressed exactly like the girls. It should be said that all the girls wear this dress whether they are nine or nineteen years old, and as it is much appreciated by them there is no doubt but that when they come to have girls of their own they will support any movement in favour of the more general adoption of a sensible costume. 


\section{XVIII}

\section{WEDDING GARMENTS}

THE VEIL-BRIDESMAIDS AND BRIBERY-OLD SHOES

-ORANGE BLOSSOM

\section{WEDDINGS are ceremonies in connection with which we may look for some points of interest, as customs} in connection with them change but slowly. In this country, if convention be followed, the bride's dress is of white.

The veil that is worn recalls the primitive head-dress that was bound by a fillet, and, like that of the nun, may well be derived from the wimple, though it is said to represent the canopy which in many countries, and by the Jews in our own, is held over, or erected above, the bride and bridegroom. Flowers take a part in the adornment of the bride, and the special use of orange blossom will be dealt with when discussing wedding crowns.

It is customary for the bridesmaids to be dressed alike, and they often wear some ornament which has been presented to them by the bridegroom. It may be that this is a survival like many other wedding customs of the old marriage by capture, for in some countries the girl friends of the bride will not allow her to be approached by the bridegroom until he has given them presents, or in reality bribed them. Now, like tipping, it is merely a custom that must be followed, but originally no doubt the bridegroom and his accomplice, the best man, might have found that what they could not do by force they might encompass by bribery. 
The expression "to tie the nuptial knot" takes its origin from the fact that, among the Babylonians, the priest who conducted the wedding used to take a thread from the garment of the bride and another from that of the bridegroom. These he tied together into a knot and presented to the bride as a symbol of the binding nature of the union between her and her husband.

There is an article of dress which often plays a part at weddings, for old shoes are usually thrown after the newlymarried pair, while boots, with a hole in them, filled with rice, are hung from the backs of carriages, and satin slippers have on occasion been fastened to the carriage door handle of the railway train which speeds the pair on their honeymoon.

We all know that the throwing of old slippers is intended to bring luck to the bride and bridegroom, but it is not apparent what particular form it is intended that the blessing should take, and the origin of the custom is difficult to determine. Mr. James E. Crombie, ${ }^{24}$ after carefully considering the various superstitions connected with weddings and shoes, has come to the conclusion that the intention is to ensure that the young couple shall be blessed with children, and that old shoes are thrown because of the idea that the essence or life of the individual that wore them remains in them, and makes them powerful talismans.

In this connection it may be well to consider the importance which shoes have assumed at various times in connection with weddings and otherwise. So long ago as the year I29I, a law in Hamburg ordered that the bridegroom should give his bride a pair of shoes, and it is still a custom in Transylvania for the bridegroom to make a similar present on his wedding morning. In Greece the best man puts a new pair of boots, supplied by the bridegroom, on to the feet of the bride when she leaves her father's house. In Bulgaria a money present which the bridegroom makes to the relatives of the bride is called shoe money, and with it the father of the family buys shoes for it. This 
money is said to be a relic of the price that was paid to the clan from which a wife was taken.

Shoes have figured as part of wages, and they were thrown over the heads of the O'Neils by the O'Cahans when the former were chosen chiefs. This was done to symbolize the superiority of the throwers. In Russia, the wives as part of the wedding festivities remove their husband's boots in order to show their subjection to him, though while the bride dutifully takes off her lord and master's boots as a sign of subserviency, she always hits him on the head with one of them to show that she is not one whit inferior to him. It is said that the Hebrew word for shoe and wife are identical, and a Bedouin form of divorce is "She is my slipper, I have cast her off." The casting of a shoe over land, as mentioned in the Bible, was symbolical of conquering it.

As regards fruitfulness, the Eskimo women carry a piece of an old shoe which has once been worn by European sailors, to make them prolific mothers. Women who are blessed with families in China present shoes to the "Mother goddess," and those who wish for children borrow these shoes and vow that if the desired result is effected they will present another one to the divinity when the borrowed shoe is returned.

Mr. Crombie gives a number of instances to show that there is still a belief that the souls of persons may live in their shoes. In the Museum of Northern Antiquities at Copenhagen is a mummified corpse of a woman who was intentionally drowned in a bog, and from her body, after the murder, a shoe had been removed. During the Arran murder case at Edinburgh, in I889, it transpired that the boots of the murdered man had been removed by the local constable, who had buried them on the seashore between high and low water marks. No explanation was forthcoming, though the man admitted that it was by the orders of his senior officer that he put them out of sight. There is no doubt but that the idea underlying the action was that of preventing the ghost of the murdered man from walking. 
It must not be forgotten that shoes used to be thrown after anybody when he or she was starting on a journey, which in old days was a risky business, and Ben Jonson wrote, "Would I had Kemp's shoes to throw after you." This has been interpreted as meaning that Kemp was a lucky individual, and that something of him and his good fortune remained in his shoes. Summing up his remarks, Mr. Crombie says with regard to throwing shoes at weddings that by doing so "we should be doing for the young couple, in a more pleasant way, exactly the same as the relatives of the Galla bride did for her when they anointed her from top to toe with bullock's blood. We should be doing for them with shoes what our Aryan ancestors did for their cattle with the sacred parna rod, and what the herdsmen of Sweden and The Mark do to this day, when on the Ist of May they watch on which branch of the mountain ash the sun first strikes, and then, cutting it down, beat the yearling heifers with it on the loins and haunches, repeating at each stroke a verse in which they pray that as sap comes into the birch so may milk fill the cow's udder. We should be doing with shoes what the Romans did in ancient Rome at the festival of the Lupercalia, when the boys, armed with strips of the skin of the slaughtered goats, used to rush through the city striking all they met, and where women, particularly those who desired to be made fruitful, placed themselves naked in the way, and received the blows of the Luperci on their palms."

At a wedding sometimes the priest's vestments play a part. It is customary in some continental countries for the priest to wrap the hands of the bride and bridegroom in his stole, and even in some of our English churches the contracting parties are instructed to take hold of the stole by the officiating clergyman. We might mention that in many countriès the bridal dresses are very beautiful, and are often survivals of very old-fashioned costumes. The Norwegian bridal dress is an instance of this. The wearing of a bridal crown is also a custom 
in Scandinavia, where it is said that every parish possesses its special crown which is the property of the church, but the use of it is only sanctioned when the bride bears an irreproachable character.

The wearing of orange blossom has apparently the same meaning, and it may be mentioned that on funeral monuments or brasses the wearing of a garland by the effigy of a girl means that she died a virgin. 


\section{XIX}

\section{MOURNING}

COLOURS ASSOCIATED WITH MOURNING--WIDOWS' WEEDSPERENNIAL MOURNING

THE ceremonies connected with death and burial are no exception to the rule which we have laid down, that on solemn and important occasions primitive customs and costumes are most commonly to be met with. The making of clothes from bark has come to have a special significance in the case of races which no longer adopt this in everyday life. The Kayans of Borneo now ordinarily wear smart foreign stuffs which they get from traders; but when they go into mourning they discard these garments, and return once more to the old native garment of bark cloth. The putting on of sackcloth is no doubt a similar custom, and dishevelling of locks is also in keeping with it.

Among the many curious customs connected with funeral rites which survive in civilized countries, the adoption of some kind of mourning dress is very general. Sombre black has come to be associated in our minds with mourning, but other colours are used among other nations, and even in this country. The drapery with which the hats of the hired mourners at a child's funeral are veiled are white instead of black. White ostrich feathers may appear on the horses' heads', and white adorns their trappings. Royalty is still privileged to have a special mourning colour-purple is used at state funerals, and grey is looked upon as half-mourning. 
In China, white is the colour used instead of black, and other Oriental nations wear yellow. In modern Egypt, at a funeral, the women, whether relatives or servants of the deceased, are distinguished by a strip of linen or muslin bound round the head and tied in a single knot behind. This stuff is usually of a blue colour. The women of ancient Egypt, as shown on the walls of tombs, wore a similar bandage round their heads. Excessive mourning is now becoming a thing of the past, and there is no need for such laws as were made at the end of the fifteenth century to restrict extravagance in mourning attire. Nowadays men may follow the custom observed by those in the army, and those who wear Highland dress, of putting a black band round their arm. At the most they wear black clothes and put a wider band round their hats. Among women it is only widows who wear a special costume. It is not a becoming one, though sometimes a smartness is imparted to it that is a little out of keeping with the idea of mourning. Now a widow's dress is called weeds, though this term at one time signified the whole of any woman's costume.

For the origin of the widow's veil we must go back to mediæval times, when the dress of widow ladies was similar to that of the convent. It was the custom of elderly ladies whose husbands had died, to become what is called vowesses, and to go into seclusion. A relic perhaps of the practice is to be found in the kind of prejudice which still exists in the minds of some people against second marriages. The white cuffs of the widow recall those of the nurse, and similar ones are used by some members of the legal profession as part of their mourning.

When dealing with military costume we shall find that signs of mourning, when once adopted, have in some cases never been wholly abandoned. There are similar vestiges like those found in the dress of public schools, and there has been a suggestion of the same thing happening in the Navy, 
In connection with the hired mourners or mutes at funerals, now so solemnly habited in black, it may be interesting to recall that the old Roman mimes, of whom we have seen that Punch was originally one, were employed at funerals to imitate the language and manners of the deceased. 


\section{$\mathrm{XX}$ \\ COSTUME CONNECTED WITH THE CHRISTIAN RELIGION}

THE SURPLICE AND "THE CLOTH"-THE CIVIL ORIGIN OF VESTMENTS-SPECIAL VESTMENTS-PROCESSIONAL VESTMENTS, SO CALLED-NUNS' DRESS-THE CHOKER

HE dress worn by clergy when conducting religious cere-
monies offers many opportunities for studying the development of garments, and illustrates at the same time how the dress used by a special class may evolve more slowly and on different lines from the same clothes that may be worn by the people at large. The case is similar to that of animals or plants which are isolated from the other members of their species, and in course of time come to differ very markedly from their far-away relatives who flourish in the old home.

We shall see that many of the ecclesiastical vestments can be traced to civil dress; but for the moment we may discuss those which are in use at the present time, and which afford additional evidence in support of our statement that the more important the ceremonial, the more ancient the costume. At the present day we find that the clergy of the Church of England preach either in a white surplice or in a black gown. We can trace the black gown to an order made by James I. but at the present day the vestments worn by the clergy of the Presbyterian Churches are rather professional, or academical like a barrister's gown, than properly ecclesiastical. We have 
already mentioned the bands (see page 32 ) which are worn with the black gown, and here we might mention that when the preacher ministers to a recognized congregation he wears them, though if he is ordained but is conducting an occasional service he does not.

Charles I gave instructions that the surplice should be worn, and had an Act passed giving him power to regulate clerical costume. But the clergy sent in a petition that matters should be left as they were, and this request seems to have been granted, as some of the ministers at the time expressed the fear that His Majesty would order them to wear hoods and bells. Mr. Macalister ${ }^{25}$ says that the surplice was originally invented to take the place of the albe, which was made so small that it was difficult to put it over the cassock when the latter garment was thick and lined with fur.

Originally the surplice was put on over the head, in the same way as the albe, the place of which it took, but some two hundred years ago the surplice was made open in front and fastened at the neck with a button. The reason for this is that in this way the surplice could be put on without disarranging the enormous wigs which were worn during the seventeenth and eighteenth centuries. The cassock, to which we have already alluded, was a long, loose coat or gown, which was worn by both sexes from the eleventh century onwards. The name was applied to the coat adopted by foot soldiers in the time of Elizabeth. In the case of the laity, it was abandoned in favour of the shorter and more convenient coat.

The black coat of the modern clergy, whom we term "the cloth," no doubt represents the cassock, while it is worn ordinarily by many Roman Catholic clergy, and some High Churchmen, as an everyday garment, for which it was originally intended. The row of buttons which now fasten the long cassocks from neck to the foot have been humorously compared by Lord Grimthorpe to the close row of rivets on a boiler.

With regard to the development of the more ornamental 
dress of the clergy there is a great deal to be said. In the past, two separate origins for it have been suggested, and to pursue either of these would be to take us far back into history. It has been claimed, in the first place, that modern church vestments have been derived from those of the Levitical priesthood. The other idea is that the ceremonial dress of the clergy was derived from the civil costume of the Romans. It appears, however, that careful researches have shown that the decorations which have given ecclesiastical vestments their highly ornamented character-in which they resemble certainly those used by the Jews in Temple worship-have been gradually acquired.

The dress of the ancient Christians was simple, and it seems likely that owing to the poverty of the early Church, rich clothing could hardly have been adopted. Besides, for many centuries there is no mention of such vestments as we are considering, and no records as to their having been derived from Jewish models. On the other hand, everything points to a more natural origin of the raiment concerned. Flowing garments, as we have already seen, give dignity, and we find that among the Romans such were used in dignified leisure or on occasions of state, in contradistinction to the dress of active existence, which consisted of a short tunic or chiton. It is with the first kind of dress that we have to deal.

It consisted of a tunic either short or long, over which was worn the toga which was capable of the same variety of arrangement as the plaid which still survives. Even when the toga was given up by the people generally, on the founding of the Roman Empire, it continued to be used in certain cases.

It was etiquette to wear a toga when dining with the Emperor or going to court; advocates wore it, as did clients when they visited their patrons, and it was also adopted at funerals and when sacrifices were being made.

On the face of it, it would appear likely that those who ministered to the early Christian Church would follow the 
general custom. Nothing, perhaps, affords better evidence of this having taken place than an illustration which is considered authentic of St. Gregory the Great with his father and mother. As Mr. Marriott ${ }^{26}$ points out, if it were not for the Papal pallium-that is to say, the band round his shoulders-on which crosses are embroidered, and the book of the Gospels

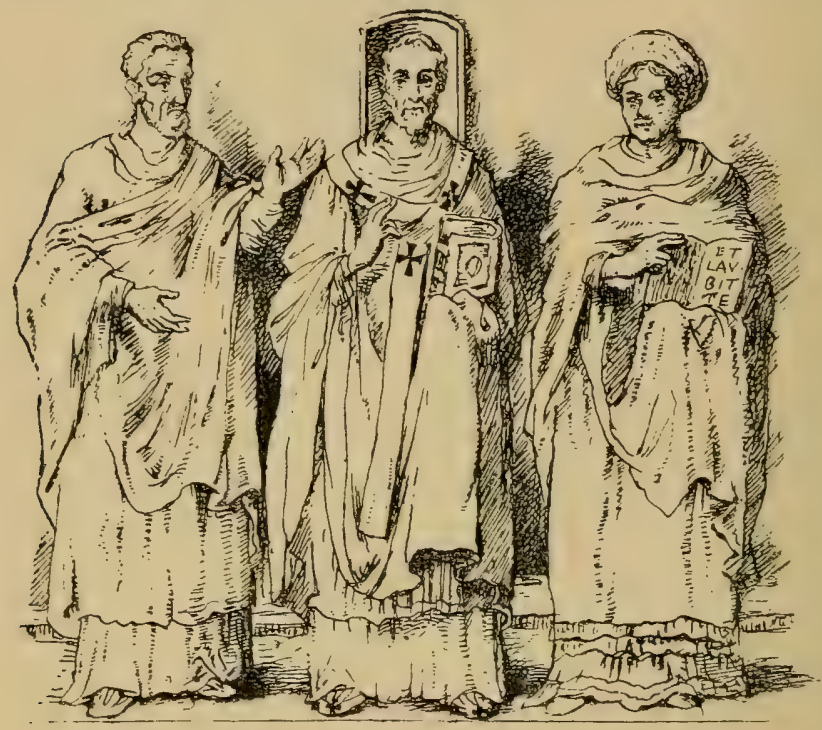

FIGURE I 28.-St. Gregory the Great with his father Gordianus, who was a senator, on his right, and his mother Sylvia on his left. This shows the similarity between ecclesiastical and civil costume in early times. From an authentic picture (after Marriott).

which he holds in his hand, it would be hard to distinguish which was the bishop and which the senator. (See Figure I28.)

From this dress it is claimed, by those who have carefully gone into the question, that ecclesiastical vestments have been developed. In connection with this, Mr. Macalister ${ }^{27}$ makes the following remarks: "Fashion in dress or ornaments is subject to constant changes, which, though perhaps individually trifling, in time amount to complete revolutions; 
but the devotees of any religion, true or false, are by nature conservative of its doctrines or observances. At first the early Christians wore the same costume both at worship and at home. Fashion," Mr. Macalister continues, "would slowly change unchecked from year to year, while ecclesiastical conservatism would retard such changes so far as they concern the dress worn at divine service; small differences would spring into existence between everyday dress and the dress of the worshipper. These differences, at first hardly perceptible, would increase as the process went on, until the two styles of costume became sharply distinguished from one another." In this connection it will be interesting to mention those vestments which antiquarians have traced to Roman costume.

The albe takes its name from the tunica alba, which was used as a purely secular garment until the ninth century. It was worn by all the ministers and deacons, but as the latter had no vestment above the albe, it came to be the special characteristic of the deacons. Usually, as the name implies, the albe was white, but in this country coloured albes were sometimes used.

We have already seen that the surplice was derived from the albe, and Mr. Marriott has brought forward all the evidence that he can to show that white was the colour of the vestments at the earliest times in the history of the Church. His arguments, however, do not seem to be conclusive, and his inferences do not commend themselves to Mr. Macalister. The latter thinks, however, that the view that white was the colour appropriated in primitive times to the dress of the Christian ministry is preferable to the theory that the early vestments were of the same elaborate description as their mediæval successors. He is of opinion, nevertheless, that the passages upon which Mr. Marriott bases his arguments are quite consistent with a third alternative, namely, that no distinctive vestments were set apart for the exclusive use of 
the Christian minister during the first four centuries of the Christian era.

The dalmatic was a wide gown or tunic with long full sleeves, which was derived apparently from the albe and used by persons in high secular positions before it was adopted by the Church. In the mediæval period the dalmatic was slit for a short distance up either side and fringes were added to decorate the slits, the hems, and the ends of the sleeves. In this style the garment was worn by a bishop. There were, however, only fringes on the left sleeves and along the left side in the form of this vestment which was appropriated to a deacon.

Most elaborate explanations were offered by mediæval writers for this difference, which seems merely to be a matter of convenience for the deacon, who served at the altar. It was important that he should have his right side free, and the heavy fringes would have got into his way. One of the ideas with regard to the fringe was that the absence from the right side symbolizes our freedom from care in the world to come; but why, Mr. Macalister asks, was not the bishop to be exempt from care in the future world? In connection with the coronation of English sovereigns the dalmatic is still used, as well as representatives of other ecclesiastical vestments, but to these we shall refer again.

It is not at all unlikely that the stole which a clergyman wears after the fashion of an untied tie, and which hangs from his neck nearly to the ground, is really the same thing as our handkerchief, and it is certain that it was employed originally as a scarf or orarium. In many Roman monuments which are not of an ecclesiastical character, scarves are worn over the rest of the dress. They pass over the left shoulder, diagonally, towards the right side, and are fastened under the right arm. They are not to be confounded with the two bands of purple (or clavi) which on the tunics of senators and other important men ran round the sides of the neck openings and down to the lower hem. 
It is probable that the scarves were used in the same way as favours and "colours" among ourselves. It is recorded that Aurelian was the first emperor who distributed "oraria " as presents to the people to be worn as favours. In this connection we must not forget the ribbons of the Knightly Orders, which we have already mentioned when speaking of the baldric.

The Fourth Council of Toledo enacted that deacons should wear their stoles over their left shoulder so that their right arm might be free to facilitate the execution of their duties in divine service. An English church vestment actually goes by the name of the scarf, and is a broad black band of silk worn in the same way as the stole. It is probably a modification of some article of university costume, possibly the tippet (see page 158 ), and is worn by Doctors of Divinity and the clerical authorities of Collegiate and Cathedral bodies.

The outdoor garment which replaced the toga took several forms. One of these had already been in use for some time as part of the dress of the lower classes and of slaves. Speaking briefly, it rose in the world, and emperors even wore it when they were travelling. One form, called the casula, is of interest to us because it is the forerunner of the chasuble.

So much attention has been drawn to ecclesiastical vestments of recent years, owing to the adoption by English High Church clergy of those in which Roman Catholic priests celebrate Mass, that it may be perhaps of interest, even at the risk of recapitulation, to consider them. It should be said at the outset that the stripes of embroidery, which are often very elaborate and enriched with jewels, which appear on vestments such as the amice and albe, are called apparels.

To garments which are white and have at times to be washed, these ornaments are sewn or otherwise attached, so that they can be removed when it is necessary and replaced. The amice we have not yet mentioned, as it is of mediæval origin and did not come into our consideration of the evolution of modern vestments from Roman dress. It was a rectangular 
piece of linen, about thirty-six inches by twenty-five inches, with an apparel sewn along one edge and a cross embroidered in the centre. This the priest at the present time wears round his neck. The outer garment or chasuble, which is richly ornamented, we have traced to the garment which replaced

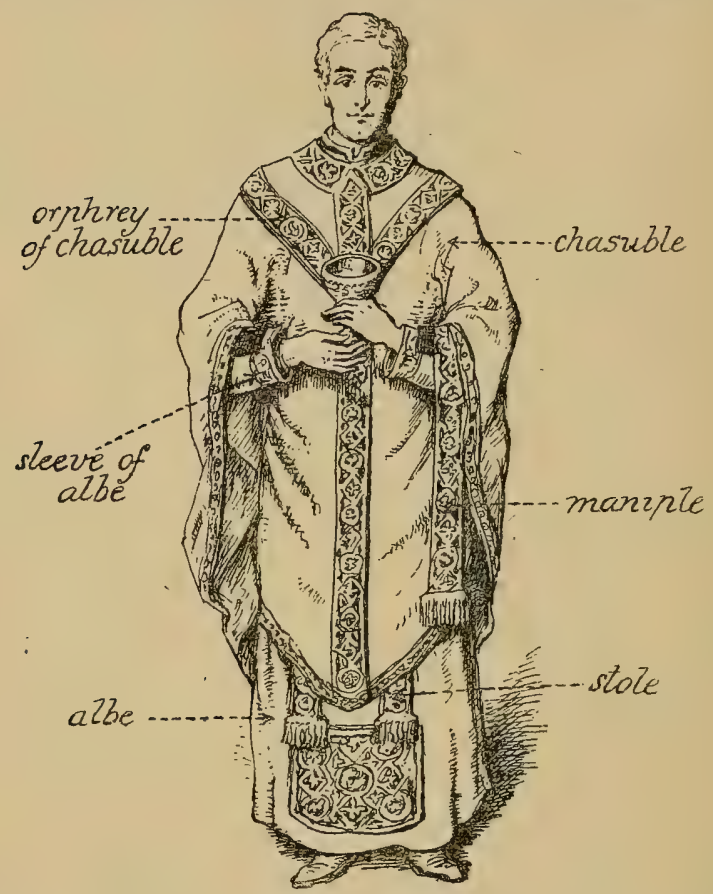

FIGURE I29.-A priest in the vestments now worn at the celebration of the Eucharist.

the Roman toga, and as it is without sleeves and has become heavier it has been found necessary to slit up the sides. Under this the stole is worn over the albe, and only its ends appear beneath the chasuble. (See Figure I29.) There is ornamentation on the sleeves of the albe, where they show, and on the back and front of it where it is seen below the chasuble.

The apparels, according to Druitt, are possibly the remains 
of the purple bands and other ornamentations of the Roman tunic, from which we have seen that the albe was derived. Over the left arm the priest carries a maniple which is something like a stole. This was originally made of linen, and worn over the fingers of the left hand. There is no doubt but that it was once a napkin and, according to Mr. G. C. Coulton, ${ }^{28}$ originally used in the fashion of a modern pockethandkerchief. That it was a napkin is shown by quotations from ancient writers, and there seems no doubt also that many refinements of Roman civilization, of which the pockethandkerchief was one, were lost in the later Middle Ages. In fact, the handkerchief only began to come into general use in polite society about Henry VIII's reign, and the maniple of the ministrant at the altar must have lost its original use, or Bernard would not have twice warned him against blowing his nose on his chasuble or surplice.

When speaking of the handkerchief, there is another use which we may mention. It was often employed for ceremonial purposes in connection with the giving of presents, and this idea seems to have come from Eastern lands, where gifts are wrapped in highly ornamental covers. In the parable of the talents, one of them, it will be remembered, was wrapped in a napkin, and even to-day the labourer has his dinner taken to him in a brightly coloured cotton handkerchief.

Among the special vestments of bishops are the dalmatic, which we have already described, and the tunicle, which originally did not differ from it, and began to be worn beneath it about the twelfth century. Others are the buskins or stockings (which were originally reserved for the pope), sandals, ring, gloves, and mitre, together with a pastoral staff adapted from the shepherd's crook.

Archbishops have a cross staff and a pallium or pall which is probably derived from the same ancestor as the stole, namely the orarium, which, we have seen, was a favour or distinction granted by the Roman Emperor. 
The word pallium has been applied to a number of garments in the past, many of which were of a flowing character, and some writers have seen in the archbishop's pall a small vestige of what was once an ample vestment. Early pictures, however, show the pall looped round the shoulders with one end hanging in front of the body and one behind. Mr. Macalister says that it was difficult sometimes to distinguish between it and the stole, and that the next step in its evolution was to knot the free ends to the loops as shown in the eighth, ninth, and tenth centuries. From this it was but an easy step to the final form which consists of an oval loop with a long tail pendent from each of its ends, so that when it is worn on the person it makes a capital " $Y$ " on the back and another on the chest. It should be pointed out that the pall must not be confounded with the apparel of the chasuble called the orphrey, which also has a " $\mathrm{Y}$ " shape.

In connection with the manufacture of the pall there are some interesting proceedings. It is made from the wool of two lambs, and they are solemnly blessed on Saint Agnes's day in the church dedicated in the name of that saint at Rome. The animals are chosen with special reference to their whiteness and goodness, and are carried into Rorne in separate baskets, which are slung over a horse's back.

On the way to the church, the Pope makes the sign of the cross from a window over the lambs, and they, after Mass has been celebrated and they have been blessed by the celebrant, go back to the Pope, who sends them to a nunnery, where they are shorn and the wool made into palls by the nuns.

The modern pall has six black crosses on it, but previous to the eighth century it had sometimes four, sometimes eight, worked in purple.

At first the pall was fastened by gold pins to the chasuble to keep it in place, but just as ladies now use little lead weights to keep parts of their dress in position, so lead was used to hold the archbishop's pall in place. The effigy of 
Albrect von Brandenburg in I555, at Mayence, shows two palls, which probably indicate that he was Archbishop of Magdeburg as well as of Mayence. This repetition can hardly be strictly correct, as the pall could only be worn within the Archbishop's province.

Archbishops in olden days appeared to have had no authority to act until they received their pall from the Pope. The honour was, however, bestowed occasionally on bishops. The pall is generally shown on the coats of arms of archbishops. (See Figure I30.)

The cope is one of the so-called processional vestments. It does not appear before the ninth century, and is apparently connected with Roman

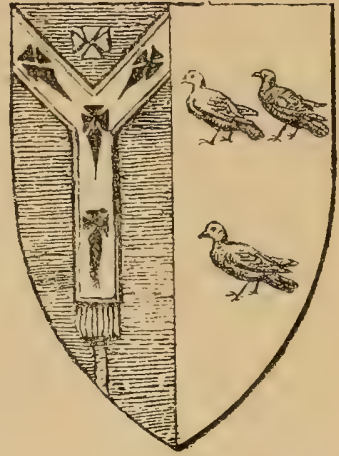

FIGURE I30.- The coat of arms of Thomas à Becket. Showing an archbishop's pall. dress. It was an outer cloak without sleeves, and originally was used as a protection from the weather at open-air processions in Rome, its ancestor probably being the lacerna. In a similar way the almuce was a hood to protect the head, and such articles, as Mr. Macalister says, the clergy would continue to adopt in their cold and draughty churches or in open-air processions.

Of monastic habits the earliest was the Benedictine, consisting of a cassock over which was worn the cowl-a large, loose gown, with hanging sleeves and a hood attached to it. In the old times the costume of abbesses and nuns resembled the mourning habit of widows, who often retired to end their days in a convent. When the English Church was reformed, the Mass vestments practically disappeared. The first Prayer Book of Edward VI prescribed for the Holy Communion, a white albe, without any apparels, with a vestment or cope, while the assistant priest or deacons were to wear albes with tunicles. The cope was also to be worn with a plain albe or 
surplice on Wednesdays and Fridays when there was no communion. The bishop was to wear a rochet, a surplice or albe, and a cope or vestment. The second Prayer Book prohibited the use of the albe, vestment, or cope to the minister, allowing him only a surplice, while the archbishop or bishop was allowed a rochet. The Act of Uniformity upheld the ornaments rubric of the first Prayer Book of Edward VI, and this has never been superseded.

The lawn sleeves of the modern bishop developed from the rochet, which was a kind of modified albe, which at first had a kind of tight-fitting sleeves or none at all. Over this rochet is worn a black satin chimere, and as it was difficult to get this over the bishop's sleeves, they were removed from the rochet and are now fastened to the chimere. The black scarf we have already considered.

It is customary at the present day for clergy of the English Church to wear the academical hood of their university degree over their surplices. This is ordained by the fifty-eighth canon, but ministers who are not graduates are permitted to wear, instead of hoods, "some decent tippet of black, be it not silk." It appears that in the time of Elizabeth, in everyday dress, ministers wore a gown and some of them a silk hood. The tippet is a survival of the almuce, which we mentioned in connection with the cope, and is one of the so-called processional dresses. It must therefore not be confounded with the amice, which is a truly ecclesiastical vestment.

As bearing on the conservatism of the Church in matters of dress, we may mention that in Holland, until recent times, the clergy wore a very old-fashioned dress, or perhaps it may better be described as a picturesque uniform, consisting of an old three-cornered hat, and a coat resembling the ordinary evening dress-coat, having a long pleated strip called "the mantle" hooked on the neck, and obviously being a survival of an early and more ample gown of some kind. They wore 
knee-breeches buckled at the knees, and buckled shoes, but this costume was only used when the minister was officiating at service.

Some of the heads of the churches in Scotland still adopt a kind of Court dress.

In turning for a moment again to the everyday dress of the clergy, the method of fastening the characteristic white choker at the back seems to have come from the bands. Thackeray in "The Newcomes" uses the name choker as meaning a white necktie, and it was also applied to the old leather stocks which the clerical collar, in its stiffness, resembles. The bishop's hat we have already alluded to, as showing a stage in the process of cocking, the brim being tied to the crown by strings. The clerical gaiters we can derive from the old episcopal buskins, while the apron appears to be a vestige of the cassock to which we have before referred.

The dress of monks usually consists of a tunic or closed gown and scapular, while there may be one or more open gowns with a hood at the back.

Nuns or Sisters of Mercy are so commonly seen in our streets, and they do so much for the benefit of the poor, and take such a part in educational matters, that their dress is very familiar to us. It is difficult to say how old it may not be, and though stiff hoods similar to those which are now in use by nuns were adopted by women generally in Tudor times, we find in the head-dress of Henry II's reign the counterpart of the linen bands which surround the face and hide the hair. The other garments of nuns may have the same origin as ecclesiastical vestments, for the dress of the Roman women was very much like that of the men. (See Figures I28 and I3I-I33.)

There are, of course, many orders, congregations, and communities of nuns, but we may describe the dress of one of the latter, and then make a few additional remarks. In the case of the Kilburn Sisters of the Church, who are English Catholics-but who have dedicated their lives to religion in 
the same way as the Roman Catholic nuns-the indoor dress consists of a white cap, the descendant of the Norman

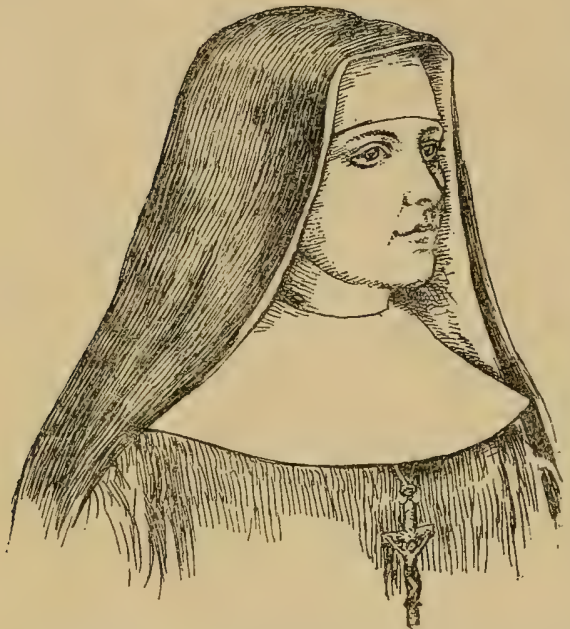

FIGURE I3I.-The head-dress of a nun showing the veil and breast-cloth derived from the wimple, the cap which represents the chin-cloth, together with the frontal and the hood. chin-band, which fits tightly round the head -as the hair of all nuns is, of course, cut closeand it is gathered round the face with a string. This cap, if it comes down low on the forehead, correspondingly covers the chin, but in many cases the latter is free. Over the white cap in indoor dress a black veil is worn in the case of professed nuns, a blue veil by novices, while postulants, who may be taken as corresponding to probationers in a hospital, wear only a cap, though in chapel they have a white veil as well. Round the neck of the Sister is a white collar, which in this case is separate from the cap and buttons on to it at one side.

This collar, which like the veil may be traced to the wimple of Norman and later ladies, is also called a breast cloth or a gremial, and may be, as we have indicated, made in one piece with the cap.

In outdoor dress a stiff white hood is placed over the indoor head-dress, and over that again comes the outdoor black veil.

It should be mentioned that the Kilburn Sisters now pin their veils to the sides of their linen caps in exactly the same way that the dame in the time of the early Plantagenets did her wimple to the sides of her chin-band. 
For working Sisters, the rest of the costume is a habit with skin-tight sleeves, though there are also most voluminous outer sleeves which are detachable and can be removed. A small cape is buttoned across the chest, and the number of buttons corresponds with the letters in the word "Obedience." An apron is also worn and a thick girdle, to one of the hanging ends of which a cross is attached. Other Sisters wear a scapular with shoulder-straps, over a white cape. Nuns are not allowed to wear gloves, and some orders use sandals, though

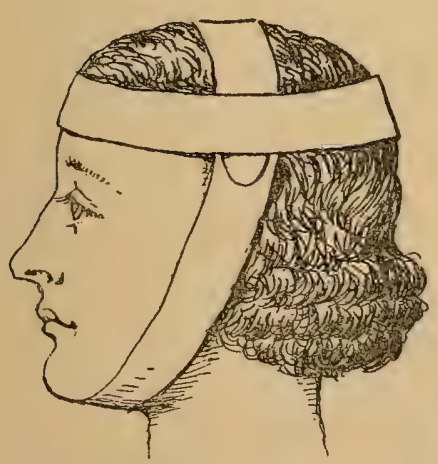

FIgURE I33.-The chin-band and forehead strap after the wimple has been removed (after Calthrop).

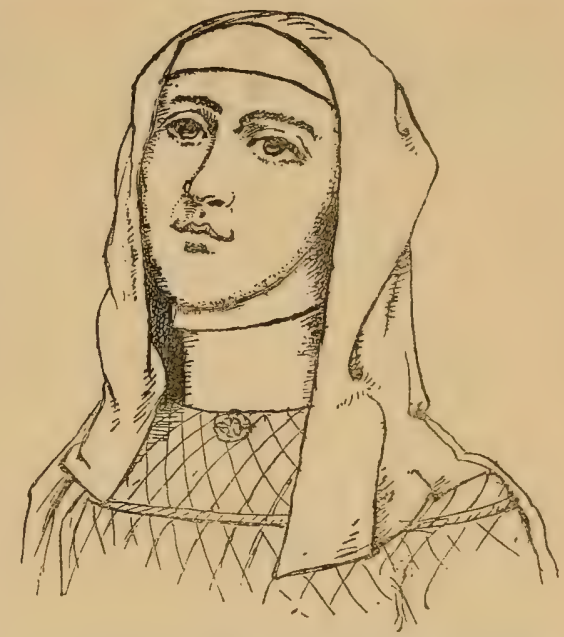

Figure I32.-The head-dress of a lady of the time of Henry II. The wimple is shown covering the chin and head-bands (after Calthrop).

absolutely bare-footed orders exist.

The lay sisters of the community under consideration wear a blue habit and a white cap with flaps. Some orders, in addition to the white cap, wear a plain band round the forehead over it, which is called a frontal, and is seen in the dress of Henry II's time. (See Figures I3I and I33.)

Professed sisters wear a wedding ring on the third finger of their right hand. The 
white outdoor stiffened hoods often stand right up from the head in a very striking way, and sometimes no veils are worn. Some of the caps, which are made in one piece with the collar, are fastened under the chin by two strings, and the goffered edges of the collar recall the bands of the Stuart period. 


\section{$\mathrm{XXI}$}

\section{SUNDAY CLOTHES}

THE SIGNIFICANCE OF SUNDAY CLOTHES-THE WEARING OF HATS IN CHURCH BY LADIES

SUNDAY clothes are a time-honoured institution, though it is a sign of the times that many now make no difference between their weekday costume and that which they wear on the day of rest, or if they do, they only put on garments which are appropriate to the relaxations in which they are accustomed to indulge. St. Jerome and St. Clement both exhorted the early Christian worshippers to wear a special dress for worship, and the Jews in their synagogues put on a vestment called a talith, which is used by the whole of the congregation as well as by the officiating minister.

We quote the following passage from St. Clement ${ }^{29}$ because it deals with the question of women having their heads covered while at church: "The wife and the husband should take their way unto the church, in seemly apparel, with unaffected gait, and speech refrained; having love unfeigned; pure in body and pure in heart ; fitly decked for prayer to God. And this further let the woman have: let her wholly cover her head (unless perchance she be at home), for so dressed she will have respect and be withdrawn from gazing eyes. And if thus with modesty, and with a veil, she covereth her own eyes, she shall neither be misled herself, nor shall she draw others, by the exposure of her face, into the dangerous path of sin. 
For this willeth the Word ; seeing that it is meet for the woman that she pray with covered head. . . . But then so as they, who are joined to Christ, adorn themselves, in a more solemn fashion, for assemblies of the church, even such should they ever be, even so be fashioned, all the days of their life. 'To be, not seem to be,' let that be their watchword; gentle, reverent, full of holy love, at one time not less than at another.

"But it is not so, indeed. Somehow doth it come about, that, with change of place, they change both their habit and their manners; even as the polypus is said to change each one his colour to the semblance of the rock whereby he dwells."

It will be remembered that not long ago objection was taken by a minister to women appearing in his church without any hats. It would appear that the whole custom is a relic of that still observed in eastern countries, where women cover not only their heads, but also their faces, though, as pointed out in an earlier chapter (see page Io), in some places it is still considered more immodest to uncover the back of the head than to expose any other part of the person; and in Egypt, for instance, an Arab woman disturbed when drawing water will throw her single garment over her head in order to hide it.

One is rather afraid that those ladies who follow the lines laid down by St. Clement as to covering their heads in church sometimes obey his injunctions in the letter rather than in the spirit. For scoffers have been found who say that one of the reasons why fashionable ladies go to church is to show their own new hats and gowns and to look at those belonging to their neighbours. The question of covering the head was touched upon when dealing with servants' dress in connection with the cap of the housemaid. (See page Iog.)

The greatest contrast between Sunday and weekday clothes is to be looked for in the country among agricultural labourers, as the cessation of labour gives an opportunity for discarding the rough and heavy garments of the field in favour of something lighter and of better quality, and this quite apart from the 
religious idea which no doubt first led to the practice. Probably the custom of putting on Sunday clothes in the country will survive until the rural exodus, which has unfortunately begun, has led to the complete depopulation of our villages. 


\section{XXII}

\section{ACADEMICAL DRESS}

GOWNS AND HANGING SLEEVES-THE FORERUNNER OF THE HOOD-THE ORIGIN OF THE DOCTOR'S HAT-THE EVOLUTION OF THE MORTAR-BOARD

M ANY complaints have been very justly made against M the solemnity, if not the ugliness, of men's modern evening dress. On important occasions it may be more or less enlivened by the ribbons and stars of various orders, but we really get a return to something of medixval brightness at those functions connected with the universities at which academical dress is worn. Then the black coats and trousers are practically hidden, in many cases by scarlet, by purple, and other coloured gowns. Occasionally there are combinations of colours which are trying to the eyes of many, but on the whole the effect is one that is pleasing and worthy of repetition. Academical dress is in itself a survival, and the gay colours are almost enough to tell us this. Records exist which show that in the fifteenth century they were already adopted by the graduates of our universities.

The evidence which has been brought forward as to the origin of academic costume points to its having been derived from that of the clergy; but there are interesting connections with civil dress, as we shall see. One of the special features of many academic gowns is their long hanging sleeves, and we shall find that so long ago as the time of William Rufus sleeves I56 
had grown so long that it had become convenient to make a hole through them through which the hand and forearm could be protruded. (See Figure r34.)

These sleeves took upon themselves all sorts of forms, and they were made so long and narrow that they resembled very much the elongation of the hood which was called a liripipe. Occasionally it was found necessary to knot them so that they should not trail upon the ground. Very few parts of dress have varied so much as sleeves, and it is said that any costume can be dated by an examination of the sleeves. Nowadays, as in the past, the length of the sleeve and of the gown itself indicates the status of the member of the university. At Oxford, for instance, the undergraduate's gown is so short that it is hardly worthy of the name, and it is without sleeves that act FIGURE I34.-Hanging sleeve of as such. The scholar's gown is

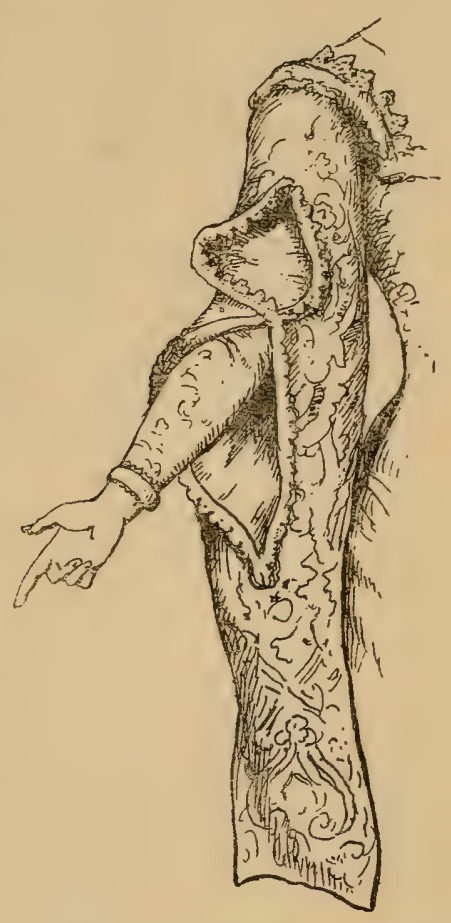
more voluminous, and the gowns of the bachelors and masters of arts are more important again, while the sleeves belonging to the latter reach nearly to the ground.

When we come, however, to the robes of the Chancellor, which are made of stiffer material, we find that the ancient character of the hanging sleeves is much more marked (see Figure I35), and there is a train so long that small pages are told off to support it. In the old days, the material of which the gowns were made, and their trimmings, indicated the rank of the wearers; and, as Mr. Druitt ${ }^{30}$ points out, the bachelor, 
for instance, was unable to use fur of so costly a kind as that worn by his academical superiors. Stuff or silk gowns still. have their significance, and in the hoods which are the survival

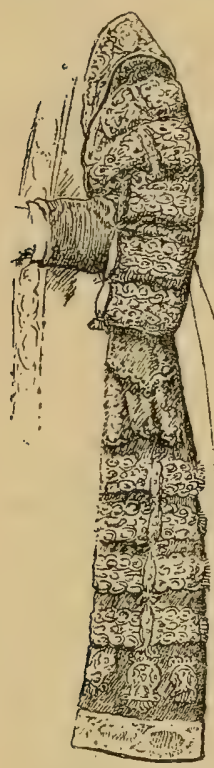

FIGURE 135.The hanging sleeve of a Chancellor of Oxford University.

of a part of dress which was once useful and worn by graduates and undergraduates alike, we find great diversity in the case of the various degrees of different universities.

As a head covering, the cap took the place of a hood, and the latter fell down behind like that often seen on a modern ulster. We have already noticed (page II4) how this peak of the hood was exaggerated, and in old times the liripipe was longer in the case of undergraduates. The modern hood of the universities has grown in size, but it has lost its long streamer. Examples are, of course, most commonly seen in churches, as it is a custom of the clergy to wear their academical hoods over their white surplices. The colour of the hood and of its lining indicates, to the initiated, the university to which the wearer belongs, and the degree which he has taken.

In early times a tippet or cape made of fur or cloth edged or lined with fur, according to the degree, was also worn. To this we have alluded when speaking of the surplice (see page I48). It seems also to have originally been a kind of hood which developed first into the almuce, one of the processional vestments of the priesthood. This was covered by the ecclesiastical cope, but was worn outside the academical gown. Doctors of Divinity were allowed to wear scarlet tippets, and the colour survives now in their academical hood, and the ordinary black almuce with its fur lining has not been greatly changed in becoming the hood of the Bachelor of Arts. 
Sometimes the tippet and sometimes the hood was worn (if we may judge from monumental brasses), but also they were both put on at the same time. In connection with Cambridge hoods Mr. E. Mansel Sympson has pointed out to me that there is a survival of the tippet itself. The figure of a doctor embroidered on a fifteenth-century cope belonging

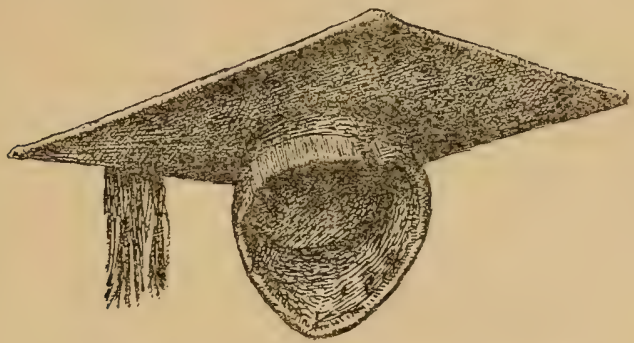

FrgURE 136.-A college cap or trencher

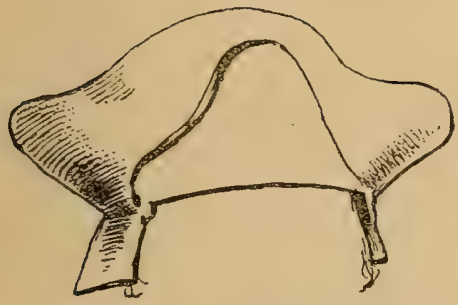

FIGURE I37.-Cranmer's hat, illustrating a stage in the evolution of a mortar-board (after Fairholt).

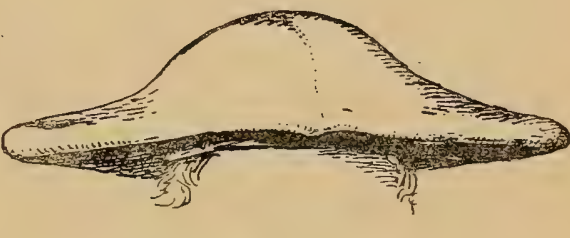

FIGURE I38. -The hat of a bishop of the Stuart Period showing a stage at which the stiffening now seen in the mortar-board was becoming necessary (after Fairholt).

to the Pro-Cathedral of the Apostles at Clifton, depicts him wearing a tippet edged with white, a red hood, and a red cap. His gown, which is worked in gold thread, is shown with a blue lining.

Perhaps no form of head-dress is more strange than the college cap or mortar-board, or, in technical language, pileus quadratus, or cater cap. This skull-cap, with its curious square top, is not the only kind of academical head-dress. 
There is the round cap which is especially that of the doctor, while the mortar-board or trencher already mentioned is used by masters and bachelors, as well as by undergraduates and scholars. The former head-dress seems to have been very little altered, and was developed somewhere about the fourteenth century or earlier from the ecclesiastical skull-cap, which was something like an old-fashioned man's nightcap, with a tuft. The square cap is an undoubted descendant of the ecclesiastical cap of dignity, and in England this also came from the skull-cap already mentioned. Towards the end of the fifteenth century, while still used by ecclesiastics, it began to assume a square or cusped shape. Prof. E. C. Clark ${ }^{31}$. agrees with the opinion expressed to him by the late Dr. Littledale, that folds were introduced into the soft material in order to make the cap easier to hold, for by them it was stiffened. The folds became four wings, and so converted the round top into a square. From this it was but a short step to the ecclesiastical biretta of the present day. Any further exaggeration of its top would cause the cap to fall down on the face, and would naturally suggest the insertion of something to stiffen it and hold it out, and in the end, the square top of the cap was made of cardboard covered with cloth, and a skull-cap was fixed to it underneath. (See Figure I36.)

There is a likeness between the round hat of the doctor and the Tudor flat cap, and Fairholt would derive the mortarboard from the same head-dress ; and as illustrating the story of its evolution, he compares the cap shown in the portrait of Cranmer (see Figure 137) in the British Museum with that of a bishop of the time of Charles I (see Figure I38) ; and here again the need for stiffening is obvious, if the enlargement of the crown of the cap be carried any further. 


\section{XXIII}

\section{LEGAL DRESS}

VESTIGES OF THE COIF-HOODS AND GOWNS-SIGNS OF MOURNING

$\mathrm{IT}^{\mathrm{T}}$ would be strange if the majesty of the law did not depend to some extent upon dress, and there is no doubt but that an impressiveness which would otherwise be absent from our courts is given by wigs and gowns. The wigs themselves are an interesting survival, and presumably are not more uncomfortable to the few who now wear them than they were to many in times gone by. Mrs. Ashdown states that the dress of judges is based on that of Elizabethan times. We will describe here a few interesting vestiges among those which are to be met with in legal costume.

Anyone who has an opportunity of looking on to the top of a judge's wig will notice a small circular depression about three inches across. (See Figure 139.) This has a very interesting history, and in order to trace it we shall have to look at the long wigs of the serjeants-at-law, from whose ranks in the past most of the judges used to come. On the serjeant's wig we shall find that there is a similar depression, and that it is filled with a circular white patch, having a black centre, and reminding one of two large pieces of court plaster, one stuck over the other. (See Figure 140.)

The white piece represents the coif, or close-fitting cap of white lawn or silk which resembles that of a nun, and with 
which the serjeant's-at-law on their creation were decked. From this cap, the body to which the serjeants-at-law belonged

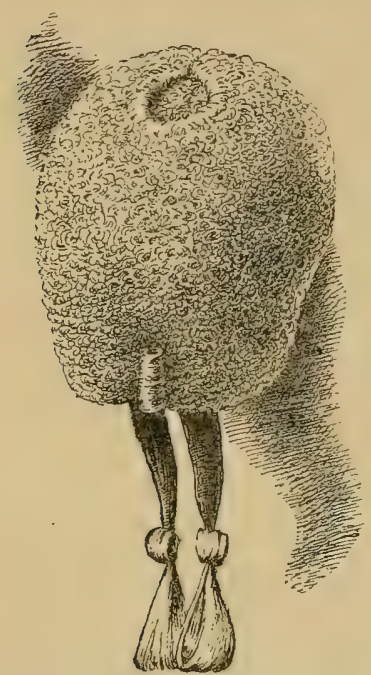

FIGURE 139.-The wig of a modern judge.

was called the Order of the Coif. It seems that the origin of this headdress cannot definitely be settled. Mr. Druitt ${ }^{32}$ and Mr. Paley Baildon are content to consider it as part of the insignia of the serjeants-at-law, in the same way that the round cap indicates the possessor of a doctor's degree, and they are not inclined to give credence to the suggestion that the coif was to hide the tonsure or to prevent its absence from being noticed. The black patch represents a black skull-cap that was worn over the coif.

After having been in existence for many hundreds of years, the order of serjeants-at-law was abolished by Mr. Gladstone. Lord Lindley, we believe, is the last member who survives. A black skull-cap is also worn by a judge, but it is not to be confounded with the cap of dignity which is used by him when pronouncing sentence, and which was ordered to be worn in church when on circuit. Ordinarily, the judge does not wear his scarlet gown, but a black one, the girdle of which has grown to a very great width.

The drab colour of the trimmings, which does not harmonize well with the rest of the gown, has recently begun to give way to primrose, and the change is due to the initiative of the late Lord Coleridge.

It is said that the black gowns which

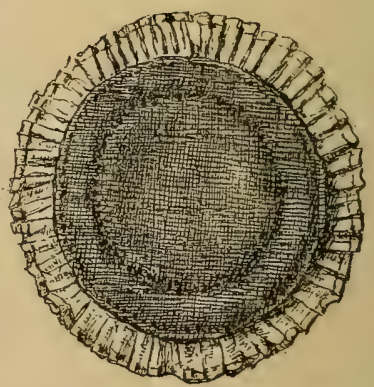

FIGURE I 40.- The vestige of the coif from the wig of a sergeant-at-law. 
are worn by the King's Counsel and other barristers superseded the coloured ones on the death of Queen Mary II, and in reality were intended as mourning which has never been discarded. Legal gowns have come down with very little change from the Niddle Ages, and are doubtless derived from ecclesiastical through academical costume. The original robes of the serjeants-at-law were somewhat striking in colour, for taking a line down the centre of the black, one

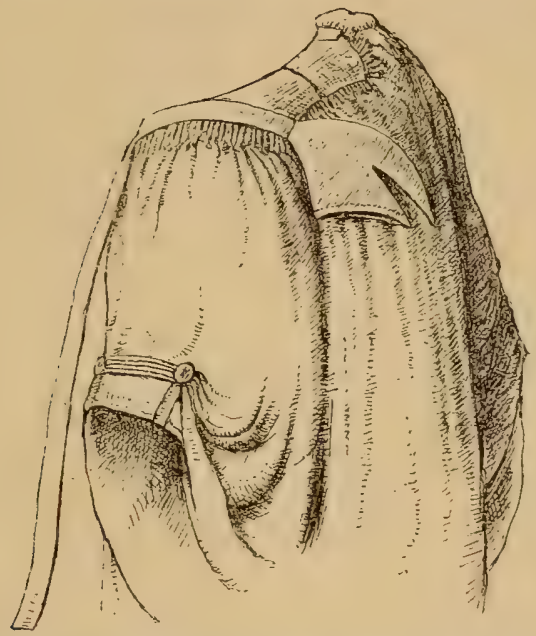

FIGURE I4I.-A barrister's gown showing the vestigal hood and its streamer. The buttons and braid which once temporarily looped up the sleeves now fix it permanently.

half was of a mustard colour and the other red, while the latter was further ornamented with green stripes. The robe of the Barons of the Exchequer was of a beautiful heliotrope tint.

The material of the gown of the King's Counsel is indicated by the phrase "taking silk." One peculiarity of the garment is that it has a large collar resembling that of court-ushers and of vergers in churches. The ordinary dress of the King's Counsel which he wears in court is interesting on account of the ornamental cuffs and the escalloped flaps of the pockets of the coat and waistcoat, which resemble those of Court dress. 
On the barrister's gown there is a tiny hood on the left shoulder resembling that from which the chaperon was developed, and from the vestige runs a streamer which comes over the left shoulder and hangs down in front of the gown. (See Figure I4I.) It has been said that this was intended for the reception of fees. There is also a series of buttons as well as pieces of braid on the sleeves which are survivals, and we have not the hanging sleeves of the King's Counsel, which are comparable to those seen in many academic gowns. Small falling bands are of course generally worn by members of the legal profession, and barristers and King's Counsel when in mourning have a little pleat down the middle of each band. Perhaps the most curious additions to legal costume used in order to indicate mourning are the little white lawn or muslin cuffs, like those of widows, which the King's Counsel wear on their sleeves when the Court is in mourning, or when they themselves have suffered bereavement. 


\section{XXIV}

\section{STATE AND COURT ATTIRE}

CORONATION DRESS-PARLIAMENTARY ROBES-MISTAKES IN COURT DRESS-VESTIGES OF THE WIG AND OF THE CHAPERON-COURT CARDS

THE English sovereigns are heads of the Church as well as of the State, and in connection with their coronation dress there are, as might be expected, many survivals from the past. The vestments used on the occasion in question agree almost entirely with those which we have described as being worn by a bishop at mass. We may except, however, the amice and the maniple, while the sceptre and crown take the place of the crosier and the mitre. The first vestment to be put on is of linen, and is an albe or rochet, and up to the time of James II it was provided with sleeves-it is known as the Colobium sindonis. ${ }^{33}$ Over this is placed the tunicle or dalmatic. This is made of silk, and across it is worn the stole in the same way as deacons were ordered to do in the year 56I. The custom is still followed in Greece and Rome, whereas priests generally put on the stole immediately after the albe.

Over the dalmatic comes the imperial mantle which seems to have been originally a chasuble, but is now slit up in front. This garment, which is of cloth of gold, is embroidered with eagles, that are interesting as probably representing the claim of the King of England to be Emperor of Britain and Lord Paramount over all the Islands of the West. In Charles II's 
reign further ornaments occurred in the shape of roses and fleur-de-lys, and on Queen Victoria's mantle there were roses, half red and half white, as well as thistles, shamrocks, and fleur-de-lys, while the eagles were embroidered in silver.

At the coronation of King Edward VII the vestments which we have described were all used with the exception of the albe, and to the other devices on the imperial mantle the lotus flower was added as a symbol for India, as the King was the first sovereign to be crowned as Emperor of India.

The robe which the King wears at the opening of Parliament has a cape of ermine made up in miniver style, and it is lined throughout with the same fur. We might here say that ordinary ermine is decorated with the tails of the stoat, which remain black when this animal puts on its winter dress, whereas in the case of miniver the fur is spotted all over with little black pieces made from the skin of some other animal. This has not always been the same, but at the present time Persian lamb is used.

The magnificence of the King's parliamentary robe and its train of crimson velvet may be gathered from the fact that in the making of the miniver upwards of ten thousand pieces of black fur were used. In a portrait of King Edward VII, taken when wearing this robe, he is shown in the uniform of a Field Marshal, and holds in his hand the Field Marshal's baton. The latter originally was a box in which the general carried the orders of his sovereign, and it is rather curious that what was once the emblem of the servant should come to be used by a crowned head himself.

The rank of noblemen is indicated on their parliamentary robes by the number of bands of ermine with which they are decorated. A Baron has two, a Viscount two and a half, an Earl three, a Marquis three and a half, and a Duke four, whereas on their coronation robes the same effect is gained by a similar number of rows of black spots on the miniver, which forms a kind of cape. 
As in connection with life at Court there are a number of special uniforms and official dresses which are carefully prescribed, it is likely that we should find among the dress of those surrounding the sovereign, many and excellent examples of survivals. There is, indeed, one uniform which has come down to us practically unaltered from the year 1485 . This is the dress worn by the Yeomen of the Guard, who may be looked upon as the King's Retainers. (See Figure I42.)

It is an obvious example of the point that we have dwelt upon in connection with badges and liveries, for borne on the back and chest are the royal crown and initials. Of course, the latter have altered from time to time, and when King Edward came to the throne the Tudor crown, which had been superseded by that of St. Edward, was replaced.

The development of the badges on the coat is interesting. In Henry of the Guard of Edward VII's VII's reign there was the crown and

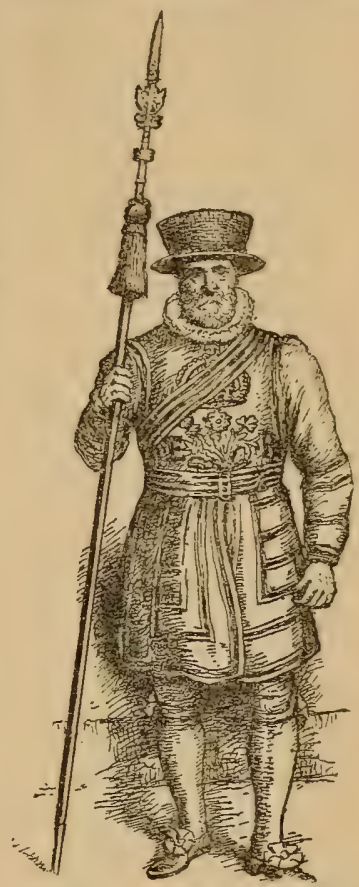
FIGURE I $42 .-\mathrm{A}$ Yeoman
of the Guard of Edward VII's reign.

the red and white rose. In the time of Anne the thistle was added, and the rose was placed upon a stalk. The Tudor crown was also replaced, for during the Stuart period St. Edward's crown had appeared, and the royal motto was added. In the Georgian period St. Edward's crown again was made use of, while George III added the shamrock.

In Fig. I42, showing the uniform in King Edward VII's time, we have the Tudor crown, the rose, thistle, and shamrock, the motto "Dieu et mon droit," and the initials " E.R."

What the original uniform was is not quite certain, but 
practically the same kind of coat was worn in Henry VIII's reign that appears now. The ruff would appear to be Elizabethan, though the hat is earlier. The officers used to wear a similar but more gorgeous uniform, but when William IV commanded that only officers of the army should be given commissions in the Guard, the present dress, which is that of a field officer of the Peninsular period, was introduced. ${ }^{34}$ When King Edward VII came to the throne he left the decision as to whether they should wear the old Tudor dress to the officers themselves, and they decided in favour of the more modern military one. We might mention the halberds that are carried by the Yeomen, and also allude to some of the duties which they have carried out, from the making of the King's bed in early times to searching the Houses of Parliament before the session opens, which is a memory of Guy Fawkes, and of attending, as they have done for centuries, at the giving of alms by the sovereign in Westminster Abbey on Maundy Thursday.

Very many uniforms seen at Court show the turned-back edges and the lining of the tails, described when we were dealing with the evolution of the coat (see page 24)-for instance, in the case of the gentlemen-at-arms, and of several officials. We may mention also the Scottish Archers, who wear a green coat with a turned-back part-which represents the lining - of red velvet.

The style of Court dress which may be worn to-day by civilians has become somewhat simpler, though ruffles and frills are still to be found in connection, and may be worn with, what is known as old-style dress that is always adopted by the legal profession. The knee-breeches come from the time of William III, and the coat in its original form dates back to the time of Napoleon. The sides of the coat have, however, been cut away, and this was done during the last reign, when the alteration was made for the convenience of those who were not accustomed to wear a sword.

The more recent simplification of Court dress has, however, 
provided pitfalls for the unwary, and all sorts of curious mistakes in small details are made. To show how easy it is to put a button too many here, or too few there, we may describe the differences between the old and new styles. On the old there are seven buttons up the front of the coat and three on the cuffs. In the new, there are but six in the first case and none in the second. Again, in the simplified coat there are no buttons below the flaps (which represent pockets), and but four buttons behind on the tails. In the old style there are three buttons below the flaps-while there are similar ornaments on the waistcoat, which is skirted-and there are six buttons on the tails. Then in addition there is the wig-bag, to which we shall refer in a moment, at the back of the coat collar, as well as the frills and ruffles. Although on the lace of these as much may be spent as on the rest of the costume, the cost of the simpler dress is really not much less than that of the other. A survival is, of course, to be seen in the sword, and in the simplified costume it is worn in a frog instead of on a sling.

We have made it evident how much a man now depends upon his tailor for correctness in the detail of his Court dress, and it is amusing to find that wig-bags are put on to modern-style coats, and that the number of buttons is often quite wrong; but if these are the faults of the tailor, it is the man himself who is responsible who goes to Court with his sword hanging at his right side. We have not heard of military men making such a mistake, but officers have been known to appear with their cross-belts over the wrong shoulder. It is a good thing for some that Court etiquette is not so strict as it has been in the past.

A curious survival is found in connection with old-style dress and some of the uniforms which are worn by officials, and we have had to mention similar vestiges when speaking of the Lord Mayor's coachman and of the Welsh Fusiliers. This is what is known as a wig-bag (see Figures I09 and II3), 
though in the Lord Chamberlain's descriptions it is now referred to by the same name as the ornament of somewhat similar

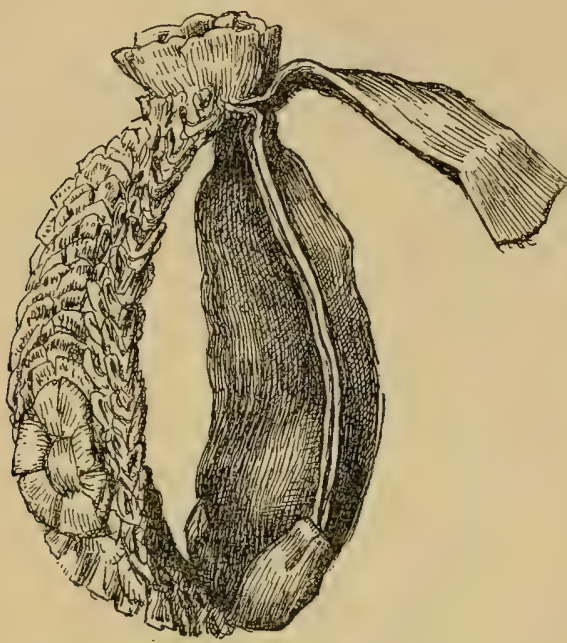

FIGURE 143--The-wig-bag or "flash" from a Court suit, showing the rosette held away and displaying the black silk bag. At the lower corners of the latter loops are seen, which are probably the remains of those through which a ribbon was passed, which went round the neck and fastened on the breast by a brooch. origin of the Welsh Fusiliers, namely, the "flash." It consists of a small bag of silk, at the bottom corners of which little satin ribbon loops are fixed, while the whole is covered by an elaborate rosette of satin ribbon, and is suspended from the back of the coat collar. The bag represents the old bag in which the bob of the wig was placed, and the loops no doubt are those through which a ribbon was passed, which went round the neck of those who wore wigs, and was secured by a jewel on the breast. This was to provide against the wig being lost, should it fall from the head of its wearer, for these curious replacements of natural hair were of considerable value, costing twenty, thirty, sixty or even more guineas. The rosette of ribbon is the modern representative of the bow that tied the wig. (See Figure r43.)

We have already traced the connection which Mr. Calthrop has shown between the cockade and the chaperon, and we might mention again that this ancient form of head-dress survives in connection with the hood of the mantle of the Knights of the Garter and of other Orders ; for instance, those of St. Patrick and of the Thistle. (See Figure I44.) 
In the case of the Knight of the Garter, the hood consists of a flat piece of crimson velvet about three-quarters of a yard across, slightly oval in shape, and at a spot a little on one side of the centre is to be found the remains of the turban of the chaperon. It is a thick ring covered outside with crimson velvet, and inside with white silk. To one side of this is fastened a long band of crimson velvet one and three-quarter times as long as the hood is wide. This represents, of course, the liripipe of the chaperon. (See page II4 and Figures I22I25.) The edges of the velvet in all cases are ornamented with a white silk piping. The hood is fixed on the right shoulder, and the band representing the liripipe is brought across the breast of the wearer. In addition there are some wide loops and ends of ribbon called the streamer, and narrow ribbons with which to fasten the structure to the mantle.

The hoods of the Orders of the Thistle and of St. Patrick are similar in construction, and in the case of the former the velvet of which they are made is blue in colour. On the mantles of other Orders only the streamer remains. On the left shoulder of the Knights of the Bath and of St. Michael and St. George there is a small vestige of aiguillettes. This is of silk cord in the former case, and of gold cord in the second. The under-dress, which is not commonly worn now, is furnished with trunk hose and silk tights, and from its appearance is known as the silver dress. Much the same style was carried out in all the Orders that we have up to the present

Orders that we have up to the present FIGURE 144.--The hood
had occasion to mention. In the more rrom the mantle of a had occasion to mention. In the noore Knight of the Garter, modern Orders there is, of course, no showing the survival of
the chaperon and its such ancient under-dress.

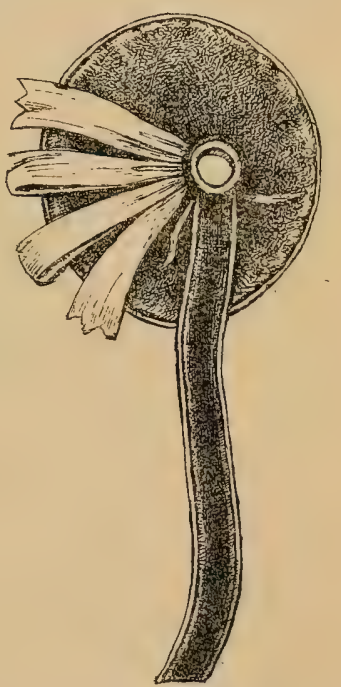
liripipe. 
If we have Kings and Queens at Court, we also have Kings and Queens and Knaves among our playing-cards, and the costumes which survive on the curious pictures which represent them in double, but without their lower limbs, are worthy of some little attention. As a matter of fact, they are Tudor dresses, slightly modified perhaps of recent years, but nevertheless, a common and widespread relic of the fashions which were in vogue when Henry VIII was going through his matrimonial troubles, and shaking this country clear from its allegiance to the Pope.

There are two series of ceremonial dresses not immediately connected with the State which it may be worth while to investigate. They are, in the first place, the liveries of the City Companies, and in the second the insignia of Masons. In the first case, on some of the gowns we find again the chaperon appearing as a hood on the shoulder, and many of the caps that are worn have survived for some centuries. A few of the companies still possess their ancient embroidered hearse cloths, which recall the early semi-religious and provident purposes of the guilds out of which the great City Companies have developed.

There seems no doubt, too, but that the apron of the Masons is actually derived from that worn by the craftsmen when at work, and in some countries it is still of the same circular form as those which were used by the English masons of the eighteenth century. Other parts of the clothing of Masons are no doubt derived from the old guild liveries, and in the fact that some high officials wear gauntlets we have a reminder of the knights' armour, and possibly a survival from the time when high officials were knights. 


\section{XXV}

\section{SURVIVALS IN MILITARY UNIFORMS}

ARMOUR-PRICKERS FOR FLINT-LOCKS-FORAGE CORDSREMINISCENCES OF GALLANTRY-REGIMENTAL BADGES - COURTSHIP COLOURS

THE cuirass of the Household troops which they wear on important occasions, as well as the metal helmets of various regiments, are survivals from the time when armour was of use, and if we examine the shoulders of certain soldiers

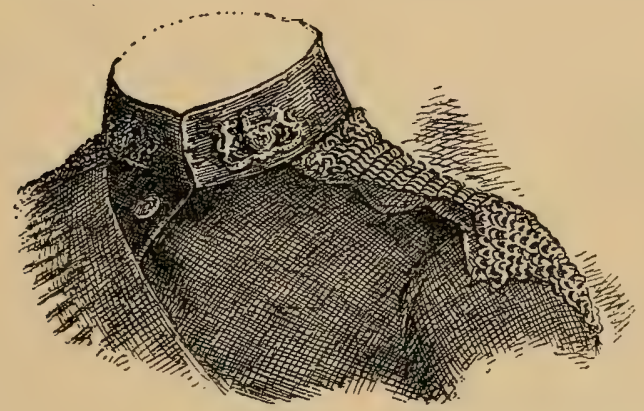

FIGURE 145.-Relic of chain mail on the shoulder of an Imperial Yeoman.

we shall find that there are vestiges of chain mail, though now this only takes the place of epaulettes. (See Figure I45.) To see chain mail in its perfection we must go back to the time of Edward I, and if we look, for instance, at the brass of Sir John D'Aubernoun (who died in the year I277) or of Sir Richard de Trumpington, A.D. I289 (see Figure I46), which are the 
earliest remaining in this country, we shall find that the chain mail now represented by a little patch on the shoulder then

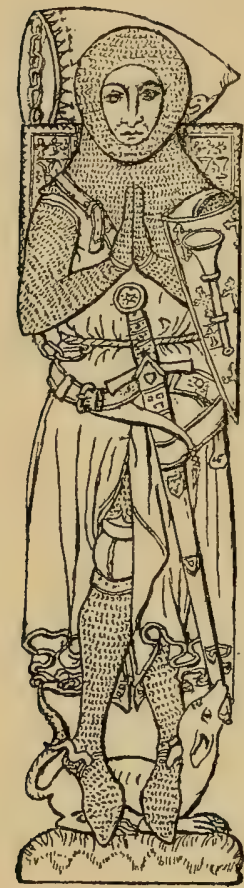

FIGURE I46.Chain mail illustrated by the brass of Sir Richard de Trumpington, A.D. I289.

covered the head and neck, arms and hands, body, feet and legs.

As time went on, plate armour was mixed with the mail, until at last, in the time of Henry IV, we get the complete plate period in which there was a breastplate and a corresponding backplate, which had already appeared in the period of transition of chain mail to plate armour. From thence onward the development of armour progressed until it gradually disappeared. In Stuart times, jack boots and spur leathers took the place of the armour on the legs, and a buff coat that on the body, with the exception of a gorget. This came to be, in the early part of the nineteenth century, merely a small badge of the officer on duty, and in a still more diminished form is to be seen in some foreign armies.

In the earlier part of the book it was made evident that military uniforms afford a fine field for research, though apart from the remains of armour, however, they are comparatively modern. It was not, indeed, until the reign : of Charles II that we meet with uniforms regularly adopted by the Army; and the red coat which has given its name to the soldier, though many regiments are dressed in other colours, was previous to that time merely a best coat. We see it now on fox-hunters and golfers, though a long coat of this colour is still worn by the King's footmen and coachmen. A writer in The Spectator, No. I29, says, when speaking of Cornwall : "Here we fancied ourselves in Charles II's reign, people having made little varia- 
tion in their dress since that time. The smartest of the country squires appear still in the Monmouth cock; when they go a-wooing (whether they have any post in the militia or not) they put on a red coat."

There had previous to the Restoration been some attempt to introduce uniform dress for soldiers quite apart from the sovereign's special guards, who, after the fashion of retainers, wore his livery. For instance, the Duke of Norfolk, in the reign of Henry VIII, issued instructions that every soldier should wear a blue coat guarded with red, the right hose to be red, the left blue, and a red stripe three fingers broad down the outside of each leg. The archers are described as wearing white gaberdines, at one time in this reign, while in 1576 those belonging to Ireland had a cassock of blue cloth with two small white guards. Red coats as well as others of blue or white were worn by the English troops in Turenne's army in I657, and examples of the last two colours are by no means extinct in the army to-day. Red, blue, grey, and green, it may be added, were all worn during the Civil War on both sides.

It must not be forgotten, however, that gay uniforms are now only used at home in times of peace, for we have learnt a lesson from the lower animals, many of which are protectively coloured, and the service uniform to-day is one calculated to render its wearer as inconspicuous as possible. Before the time of firearms which could be used with precision, and when hand-to-hand combats played a great part in war, it was necessary for two adversaries to be able to see one another, but now each tries to hide himself.

Some years ago a sketch, which was made from a cavalry man at Aldershot, was given in The Daily Mail ; side by side was shown another taken from a print representing one of Cromwell's Ironsides, and the likeness between the two is almost exact. (See Figure I47.)

Ornamental epaulettes may also be looked upon as the last remnant of armour, though the modern kind probably came 
from a shoulder-knot of Charles II's time, as they were originally intended to protect the shoulders from sword-thrusts. At the present day, though they are worn in the English Navy and are common on the Continent, they have practically disappeared from the Army.
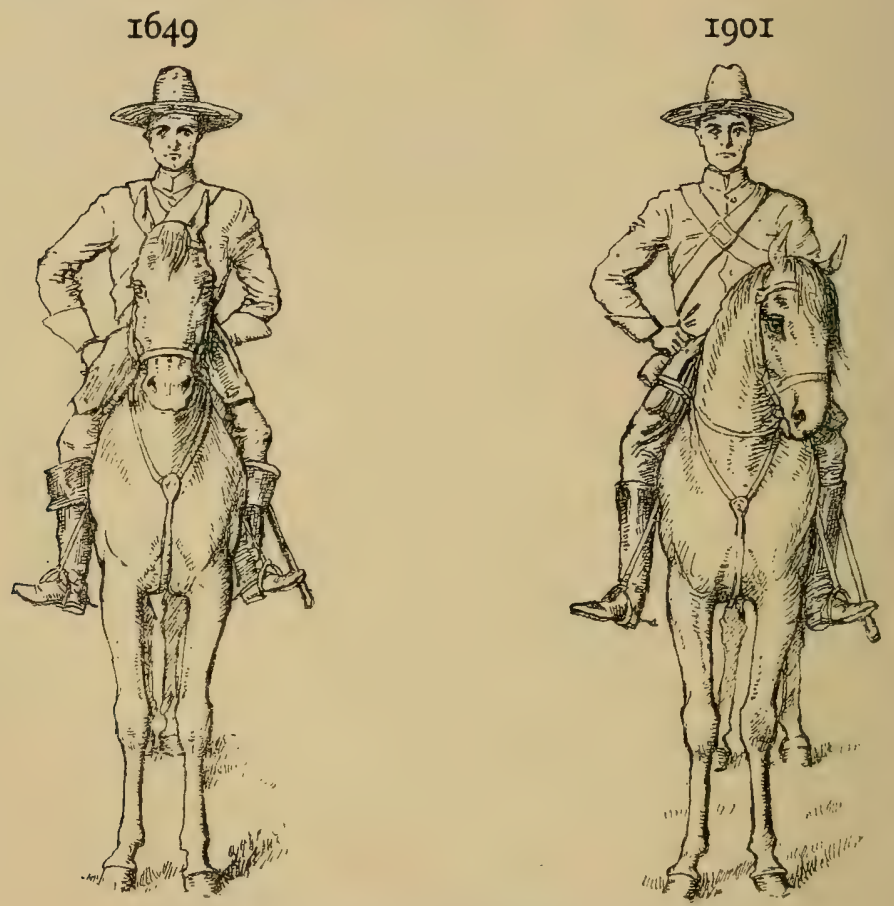

FIGURE I47.-A reversion in military equipment.

One of Cromwell's Ironsides (I649), from a print.

Copied, by permission, from The Daily Mail. in I90I.

The officers of the Yeomen of the Guard, whose uniform is that which was worn in the Peninsular War, still wear epaulettes, as do the Gentlemen-at-Arms and the Lords-Lieutenant of Counties. As we have said, there is a fine field for the study of survivals in uniforms proper, and from time to time many of these have attracted the notice of popular writers. ${ }^{35 \& 36}$ 
Additional interest is given to this subject by the fact that besides the variations which have gradually evolved, there are special features which have suddenly appeared often in connection with some important battle, which we might liken to the curious sports and freaks which sometimes occur in the natural history world.

When, in I88I, the old regimental facings were abolished, many distinctions vanished, still there are more curious details left than we shall be able to describe. We have already seen how the busby was derived from the Hungarian cap, and quite a number of other

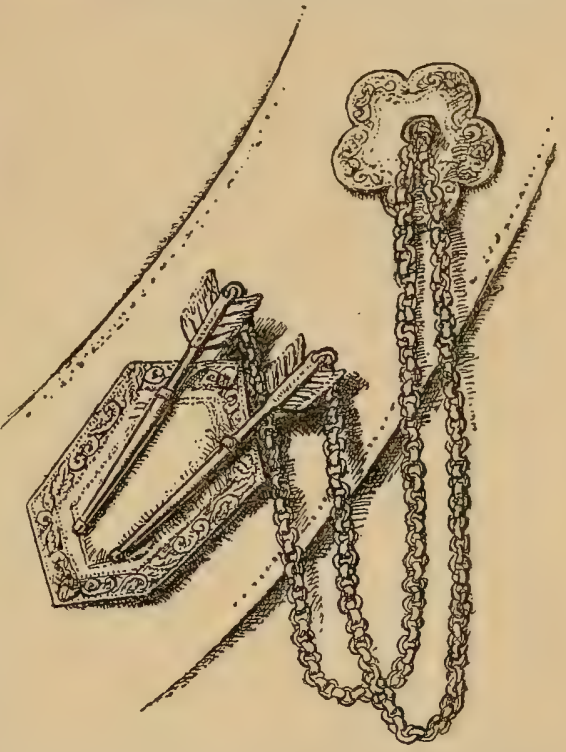

FIGURE I 48.-The prickers on the shoulderFIGURE I 48 . -The prickers on the shoulder-
belt of a Hussar, which survive from the time of flint-lock muskets. troduced from foreign countries. The square cap of the Lancer is the national headdress of the Poles, who call it a shapka, and the uniform itself came from Poland. The sling jacket or dolman of the Hussars (see Figure 82), which is now extinct in our army, was also an introduction, but still on the pouch-belt of Light Cavalry officers are the prickers fastened with silver chains, which were used with old flint-lock muzzle-loaders. (See Figure I48.)

Some of these interesting but useless instruments are furnished with plain round knobs, but others made as if they were arrows with feathered shafts. Mr. Caton Woodville gives the following explanation of the aiguillettes worn by aides-de-camp. He says that " they date from the days when the war-horses, or chargers, were of solid build and slow of 
movement, and when only the adjutants were mounted on fleet steeds. Then the head-dress was a heavy three-cornered hat perched on a wig that was itself often not too securely fastened to its wearer's head. He needed, therefore, a cord with metal tags passing round the brim and under the loops which upheld its three sides. It was fastened to the officer's shoulder, as. the weight of the felt hat, with its bars of steel as a protection against sword cuts, was considerable, and it was enough to choke a man if it should happen to dangle from his throat, so the aiguillettes have become the distinguished mark of the assistant to the general commanding in the field or garrison."

It should, however, be mentioned also that these ornaments are worn in the Household Cavalry by non-commissioned officers, and are a relic there of the days when these soldiers were gentlemen of the Royal Life Guards, who had the right to a commission in a line regiment after a certain number of years' service. Other soldiers carry them, as do also the footmen of the nobility. Horse soldiers have also an ornamental cord to their head-dresses, and it seems likely that the aiguillettes had another origin, and that prickers or some other instruments were at one time attached to them.

In the Lancers there is a very long cap-line, which has been mixed up, we are told by Mr. P. W. Reynolds, with a very interesting survival. This is the remains of a cord used for binding up grass and other forage into bundles, worn for convenience round the body, and over one shoulder by cavalry men, when it was not in use. It is known to the French as a "fourragère." In the Lancers the cap-line passes round the cap and is brought under the right shoulder-strap. So far it is the original cap-line; then it passes twice round the body, under the left arm, and under the right shoulder-strap, and ends in a festoon and a couple of acorns, which remind one of aiguillettes, on the left breast. The part that goes round the body is the old forage cord. 
The sergeants' sashes, it is said, were originally intended to make slings so that the wounded could be carried out of action with the help of pikes, and the drum-major's baton is the survival of a cane which the drill-sergeant sometimes used on the backs of the recruits. The "flash" of the Welsh Fusiliers, as we have seen, is a survival from the times when wigs were worn. Here and there we find old head-dresses once nearly universal, such as the shako which is now confined to the Highland Light Infantry and the Scottish Rifles. Other regiments, such as those of the Rifle Brigade, which have been at times used as cavalry, retain certain features of the horse soldier's uniform. For instance, the Rifle Brigade has a headdress which resembles the Hussars' busby, and instead of a sash the officers wear a cross-belt.

The officers of the Somersetshire Light Infantry, which on one occasion was turned into cavalry at a moment's notice, wear a mess jacket of the cavalry pattern; they have also a black worm in their lace, like the East Yorkshire and North Lancashire regiments, which is usually explained as being mourning for Sir John Moore in the first case, and for General Wolfe in the two others. Before turning to peculiarities which were granted for special services, we may mention the black tunics and black plumes of the farriers belonging to the Life Guards, who carry a great axe with which to kill horses that are wounded in battle, and the state trumpeters also of the Household Cavalry, who wear a highly ornamental uniform which has persisted for nearly two centuries.

There still remain relics of the time when commanding officers had a great deal to say in connection with the uniforms of their regiments. When the Cameron Highlanders were first raised in I794, Colonel Cameron did not adopt the Cameron tartan, because he did not think it would go well with a scarlet tunic, and he introduced one which had been designed by his mother, called the "Cameron Erracht," which has been worn ever since. The White Horse of Hanover appears as a badge 
in several regiments, and it is recorded that George I, objecting to the private crests of the commanding officers, replaced them in many cases with the Hanoverian device. Even now, in spite of the minute regulations of the War Office, which are continually being altered, the uniforms are not always made absolutely as they are prescribed. Little details may be added, and colonels still seem to exercise some influence in the matter. The red puggaree of the Duke of Cornwall's Light Infantry is not obtained from the regimental tailor who supplies the uniform.

The white jackets of the Guards and Highland corps which are worn in undress are still called "waistcoats," and, according to Mr. Walter Wood, are a relic of the white waistcoat which was worn under the tunic by the British soldiers down to the time of William IV. It must, however, be remembered that a waistcoat was originally an outer garment, as indicated on page ro8.

An exceedingly curious privilege is that which has been accorded to the non-commissioned officers and men of the Royal Marines, who for many years have been allowed when in mourning to cover one button of their tunics with crape. The Eighth Hussars wear their sword-belts over their shoulders, and the tradition is that at the battle of Saragossa they behaved so gallantly that they totally destroyed a corps of Spanish cavalry and took possession of their adversaries' belts.

Perhaps the most curious mark of distinction is the extra drummer of the Third Hussars, who enjoys special pay and is permitted to wear a sergeant's uniform. This privilege was granted by George III when it was brought to his notice that the regiment possessed some silver-kettledrums which they had captured. The request for this honour was made in 1778 by General Fitzroy, and his wife presented a silver collar for the use of the additional drummer which is still worn to-day. It is handsomely engraved with military devices, and fits 
closely round the throat. In full dress the Eleventh Hussars wear an ivory-hilted sword made on the model of one picked up at Bhurtpore. The Fifteenth Hussars wear the Austrian Imperial lace on account of their gallantry at Villiers-enCouche, which prevented the Emperor of Austria from falling a prisoner to the French.

The Scots Greys were given Grenadier caps, which are not worn by other cavalry regiments, for their bravery at Ramillies. The Northumberland Fusiliers have red and white hackle feathers-that is to say, that the upper part of their plume is red, and the lower part white. It is recorded that at Wilhelmstahl, and also when in St. Lucia, this regiment was victorious after great struggles, and took from the caps of the French Grenadiers who were slain enough white feathers to fit up the whole regiment with plumes, the use of which afterwards received official sanction. When, however, an order was made in I829 that white plumes should be generally worn, the Fusiliers complained that they would lose the distinction which they enjoyed, and by a compromise they were allowed to have a plume which was half red and half white. The Northumberland Fusiliers share with one or two other regiments, that distinguished themselves at the battle of Minden, the privilege of wearing roses in their caps on St. George's Day.

We might spend a considerable time in dealing with the badges of various regiments, for often the history of the latter is bound up with them. They figure on the collar and other parts of the uniform, and occasionally, as badges might be expected to do, they appear on the buttons. We have touched upon this subject in connection with George I. The Scots Greys have as a badge an eagle with outstretched wings. It commemorates the capture of a French eagle at Waterloo by Sergeant Ewart, who was given a commission for his bravery.

The Gloucestershire Regiment has a badge in front and another on the back of the helmets, because on one occasion, in Egypt, when it was attacked in the rear as well as in front 
by large bodies of French cavalry, and there was no time to form a square, the commanding officer gave the order, "Rear rank, right about face, fire!" The result was that the enemy was beaten off. In connection with this achievement the second badge was given.

An interesting tale is told with regard to the formation of the Guards by Charles II after the Restoration. There were three regiments present, and they were commanded to take up arms as the First, Second, and Third Guards, but while the first and third obeyed the order, General Monk's regiment stood still. The King, who was surprised at the apparent insubordination, asked Monk for the reason. Whereupon he said that his regiment declined to be considered second to any other. As a result, Charles is said to have answered, "Very well, they shall be my Coldstream Regiment of Foot Guards, and second to none." From this comes their motto, "Nulli secundus." It may be mentioned, also, that this regiment has a distinction which is absolutely unique in the Army, as it bears on the King's colour a small Union Jack, which commemorates the fact that Monk was an Admiral of the Fleet as well as a General.

It is only about a hundred years since the pretensions of the English sovereigns to the throne of France ceased to be evident, for it was not until the end of George III's reign that the French fleur-de-lys were removed from the Royal Arms and disappeared from our coins. There is still, however, a survival of the lilies of France on the braid of the drummers in the Guards. White lace with red crowns is what is almost universally worn by drummers in the Army, but the crown is replaced in the case mentioned by the fleur-de-lys. Whilst speaking of the Guards, one may recall that not very long ago a uniform was used by the solicitor with which these soldiers were, and in the case of the Coldstream Guards are still, provided. The solicitor, like the medical officer, wore the cocked hat that is now dying out in the Army, though generals 
and aides-de-camp still adopt this most curious outcome of the Cavalier's beaver. Here and there, as in the case of the surgeon and veterinary surgeon of the Life Guards, and the medical officers of some Territorial regiments, we still see the cocked hat. It flourishes also in Court dress, it adorns the Lord-Lieutenants and their deputies, besides maintaining its position among the officers of the Navy.

Fur, the material of which the first clothes of our ancestors were made, is still seen to a considerable extent in the Army, and is chiefly used for the construction of busbies. So important was the trade in furs for military purposes at one time, that bear-skins were classified as follows: "Officers," or first grade; "Grenadiers," or second grade ; and " unfit for the Army," or third grade. Like all features of dress which are exaggerated, the big busbies of the Guards have on more than one occasion afforded material for the caricaturist. Leech depicted the soldiers of the Brigade of Guards warming their hands and feet in their busbies, which they used as muffs; and an amusing series of sketches for the amusement of the young people was published not long ago, in which the soldier disappeared almost entirely into his busby and became a sort of Humpty-Dumpty.

Tall hats of the type of our modern silk hats were not unknown in the Army. Perhaps it may come as a shock to some that Lord Howard of Effingham is shown in a portrait wearing a top hat, in shape very similar to the modern form, but ornamented with a plume of ostrich feathers. There is, we believe, however, still one top hat which is served out by the War Office at the present day, and this is worn by the Chapel Keeper at Wellington Barracks.

Of buttons we have already spoken times out of number, and it may be interesting to mention here that the various regiments of the Brigade of Guards may be told by the arrangement of buttons on the tunic. They are arranged "at even distances apart in the Grenadiers, in twos on the Coldstreams, 
and in threes on the Scots Guards, and in fours on the Irish Guards, which were created of recent years.

We find plenty of survivals in the Army of buttons which are seen in similar places to those on civilians' clothes. Mr. P. W. Reynolds has pointed out another, which is found in connection with a cord loop on the collars of the officers of the Oxfordshire Light Infantry. This is a survival of a fashion once universal in the British Infantry, though the loop often consisted of half-inch lace instead of cord. The button was originally on a turned-down collar, and previous to that was on the coat, coming through a hole in the collar with a view of holding the latter properly in place.

If officers and sergeants were seen together it would probably be noticed that the former wear their sashes over the left shoulder, whilst the latter wear theirs over the right. To this a single exception can, however, be found. In the Twentyninth Foot the sergeants and officers both wear their sashes over the left shoulder, and this custom has been traced back to the battle of Culloden, where so many officers were slain that the sergeants had to take their places.

The drummers of the Leicestershire Regiment on State occasions wear tiger-skin aprons instead of the usual ones of pipeclayed leather. This is connected, as is also their badge, with their services in India.

A point that is perhaps not generally known is that officers going on voyages in hot climates are allowed to substitute the kamarband for the mess waistcoat, various colours being adopted by various regiments.

We have seen the origin of the red coat so far as it affects the modern army. Under these circumstances it is hardly necessary to say that it is not intended to prevent the soldier from seeing his blood when he is wounded, as has sometimes been suggested. It might be taken as acting as a warning colour like that of the wasp or hornet, but we have also noticed the way in which conspicuous dress is replaced by protectively 
coloured uniforms when the soldiers are upon active service.

We cannot help mentioning, however, one case in which the ornamental garb of peace proves useful to its wearer. We find in the animal kingdom that, whatever may happen in modern times in our own case, the males are as a rule the more brightly coloured, and we have come to call the brilliant hues with which they are endowed "courtship colours." The charm which our gallant soldiers seem to have for the fair sex surely entitles us to reckon the gay uniforms of our Army as coming into the category of " courtship colours." 


\section{XXVI}

\section{NAVAL UNIFORMS}

\section{SUPPOSED SURVIVALS-PETTICOATS AND WIDE BREECHES}

TF we had headed this chapter " survivals in naval dress," we should have been in the historic predicament of the writer who took as his topic the snakes of Ireland, and afterwards had to own that there were none. It would be better, however, if we were to say that there are no survivals of a strictly naval kind, as then we should be nearer the truth. There are, of course, in the uniform of both officers and men, plenty of survivals from civilian costume, such as we have spent much time in describing. Though the crews of the galleys, which are the boats reserved for the captains' use, had, in the case of the smart ships, long been dressed in a uniform manner, the actual uniforms of the Navy only date from a little before the year 1767 .

The colours, blue and white, so tradition says, were due to an inspiration which George II received, while the subject was under discussion, on seeing the Duchess of Bedford riding in a new habit which was of blue faced with white.

There are two points in the dress of the ordinary sailor which are commonly supposed to be interesting survivals, and indeed they appear on the surface to have all the makings of such. It has been thought that the black silk handkerchief which a sailor wears round his neck was first put on as mourning for the death of Nelson. The other matter is the blue jean collar 
which covers the similar-shaped one which is made of the same material as the sailor's jumper. This would no doubt have protected its fellow from the grease of the pigtail which sailors wore once, but Commander Robinson, who has gone into the question, says that pigtails were discarded before the blue jean collar came into existence, and at the same time tells us that black silk handkerchiefs were adopted previous to the time of Nelson. It is not perhaps very widely known that sailors at one time wore a kind of kilt or petticoat, and this no longer ago than the year I779.

Some thirty or forty years earlier there were in vogue loose slops like the petticoat breeches of the reign of Charles II, and the collar of the coat, which was open at the neck, turned back on to the shoulders.

The trousers, however, that are now adopted are tight round the body and thighs, but remain very loose round the legs, and are therefore somewhat curious. The method of buttoning is one which they share with the gentlemen of George II's time, the old-fashioned labourer, and, we believe, the bishop. 


\section{XXVII}

\section{THE COSTUME OF PUPPETS}

PUNCH AND JUDY-FASHION DOLLS-DOLLS IN SWADDLING CLOTHES-THE EGYPTIAN " SHABBIES"

BY way of a change let us turn from people to their imagesin fact, to puppets and dolls- - for these semblances and caricatures of human forms are generally clothed, and at times may present to us very curious survivals. Let us begin with Punch and Judy, and in this connection we must not forget the dog Toby, for the ruff which he wears round his neck is a reminiscence of Queen Elizabeth's reign. Punch himself, however, is very much older than his clothes, though to find the explanation of the hump in front we must examine the clothes of the time of Henry III of France, when the men's busked doublets came down low to a strap-shaped point, and had a great padded punch-like protuberance. ${ }^{37}$

For other peculiarities that we see we may have to go to the times of Henry IV of France, but the character is very many centuries older; and the careful investigations made by a friend of the present writer, Mr. George Heppel, ${ }^{38}$ into the history of Punch have shown why his present costume was adopted and what was his prototype.

As might be expected, the original Punch was a man-not Pontius Pilate, as has sometimes been suggested owing to the connection of Punch with miracle plays, but a character in the old Italian farces, which go back to the early days of Rome. 
The town most celebrated for such entertainments was Atella, situated not very far from Naples. The farcical plays were full of buffoonery, and Punch or Pulicinella was one of the stock characters, represented by a live actor, as were also the originals of the Harlequin, Pantaloon, and Scaramouch, among others.

It appears that the plays were not written as we understand a play to be written, but as a rule the plot of them was known, and a great deal of the dialogue was left to the actors themselves. From this it will be seen that the art of gagging can hardly be considered to be modern. The Italian, though by no means great as a dramatic author, was, as he is now, exceedingly good as an actor. It is said ${ }^{39}$ that for genuine fun no dramatist can beat the Neapolitan, no actor can surpass him. He writes or acts without the least effort ; it is born in him, and he cannot help it. The very beggar-boy who hunts one along the street is a consummate actor; his gestures are prolific, easy; and natural; he is a facial artist without knowing it, and he has a power of elocution and expression which are only acquired by experienced performers after many years of study.

It may perhaps come as a surprise to many, seeing how long Punch has persisted, to learn that in Italy he was not one of the important characters in the original plays, but his choice as the hero of the puppet-show depended rather on the fact that he had not so much to do as some of the others-the harlequin, for instance. Therefore his character could be better portrayed under the restricted conditions that prevailed in such an entertainment as the Punch and Judy show. It will be obvious also that only two characters can be acting at one time, as the showman has only two hands. Mr. Heppel could only trace one instance of Punch figures being worked by wires like other marionettes. This is a figure in a little book no larger than a playing-card, entitled "Scenes de Polichinelle," in the Art Library at the South Kensington Museum.

The showman in the case of the French Punch on occasion makes a virtue of necessity, and when the hero of the puppet- 
show is about to be tried for murder, the performance is interrupted in order that the following apology may be made :"The scene which we are about to have the honour to

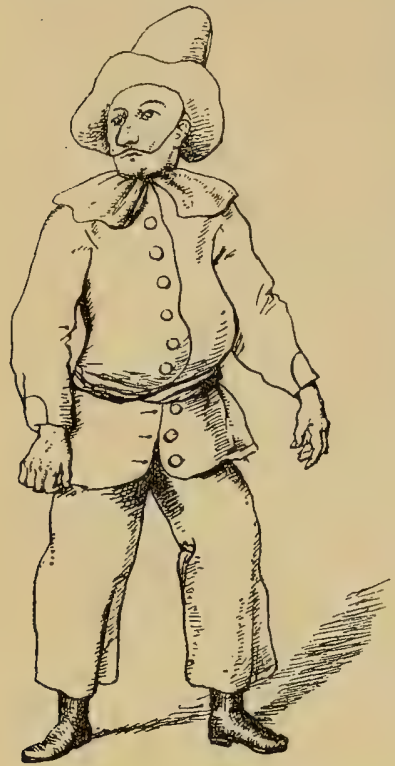
put before you requires a tolerably large number of characters. It is, indeed, impossible to suppose that so important a prisoner as Guignol should be tried without due ceremony and by a single judge, but as the director of this theatre, like the generality of mankind, has but two hands, the actors in this scene will most of them remain quite still. This need not in the least interfere with the truth of the representation, for this stillness gives the administration of justice an additional solemnity. We may suppose that the judges are asleep, which will enable them to decide free from Frgure r49.-The Oscan passion, and that the officials of the Pulicinella of I73I, without a long nose. The dress is very similar to that figured in 1630
(after Riccoboni).

court are paralysed by the majesty of the court and the magnitude of the issues to be determined."

The Punch and Judy show went on in Italy side by side with the farces that were represented by living actors, but the idea of puppet-shows is very much more ancient than this.

The clothes of Punch were plain, and illustrations made in I630 are similar to others made a hundred years later (see Figures $\mathrm{I}_{49}$ and $\mathrm{I}_{50} \mathrm{O}$.

Originally, also, Punch does not seem to have had a long nose. The exaggerated nose is, however, found on the representative of Punch which flourished in Calabria, and which went by the name of "Giangurgolo" (see Figure 550 ).

The French Punch is called Guignol, of which the derivation 
cannot be directly traced, but $\mathrm{Mr}$. Heppel has made an interesting suggestion that in the name of this character is to be found that of Giangurgolo in a contracted form.

As may have been surmised, we got our Punch and Judy by way of France, but as a human actor Punch himself came direct to England.

An ancient statuette which is figured by Ficorroni (see Figure $\mathrm{I}_{5} \mathrm{I}$ ) is supposed by antiquarians to represent Punch, and if the individual whom it represents did not go by that name, he must certainly have been one of Punch's ancestors, for the likeness to our modern hero is exceedingly great. References are made by a number of classical authors to puppet-shows, and these were also known in China as long ago as a thousand years before the Christian era.

The method also of exhibiting the puppets is not very modern, for a very interesting figure of a show embellishes the celebrated MS. of the "Roman d'Alexandre" (see Figure I52) which is preserved in the Bodleian Library at Oxford, and was executed between the years I338 and I344. The figures were evidently worked by the hands as in Punch and Judy, and that it was intended to amuse children is shown by three little girls who are represented as looking on.

Though sticks are not strictly a part of dress, unless we consider the canes of the dandies as being so, yet their usefulness nose. The dress is very similar in puppet-shows is so great that to that ficcoboni).

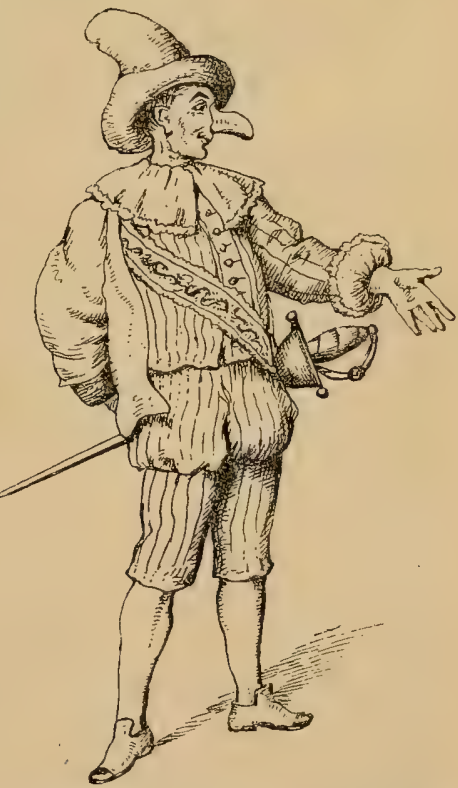

Figure I50.-The Calabrian FIGURE I5O.-The Calabrian
Giangurgolo of $173 \mathrm{I}$, with the long 
we are tempted to digress for a moment to give the comments of M. Lemercier de Neuville on the subject :-

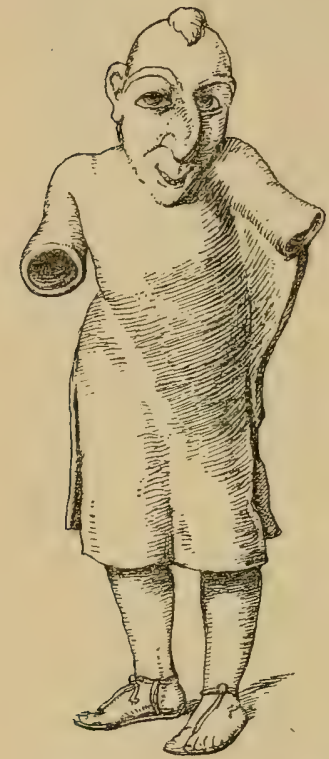

FIGURE I5I. - An ancient bronze statuette with the face and features of Punch (after Ficorroni).

"The stick! that is the great argument of Guignol, as well as of Polichinelle. The stick settles everything. It puts an end to disputes, it pays debts, it sends away troublesome people, it disciplines wives, it takes vengeance on men, it is the 'Deus ex machina' of all this Lilliputian world. What a marvellous dramatic resource it is. If a situation becomes difficult to manage, settle it with a blow of the stick. If a dénouement seems to hang fire, hasten its progress by a thrashing. The stick is above all criticism; it checkmates it, it destroys it, for it is in the right, in spite of everybody, because it is the strongest. The stick has no respect of persons. With it Guignol beats his creditors, his friends, his wife, the constable, the judge, the hangman, and the more he strikes the more he makes people laugh. There is no spoken joke that is as good as this. And yet the stick is not beautiful, nor is it new. One sees that it has done duty for a long time, for it is worn out and cracked."

We have, in fact, a record of Italian players coming to act their farces in this country in I577, but as Punch in the capacity of a person is now obsolete with us, we shall only incidentally refer to him as a living actor, though perhaps we might recall the fact that Molière introduced him into his play Le Malade Imaginaire.

We have spoken already of Punch's hump in front, and it may be interesting in this connection to give the opinion of a 
Frenchman on the subject of Punch's bodily characteristics. M. Magnin says that with a sufficient amount of exaggeration and caricature to set aside the suspicion of disloyalty, the Punch figure recalls the appearance of some Gascon officer imitating the walk and demeanour of Henry IV in the Guard

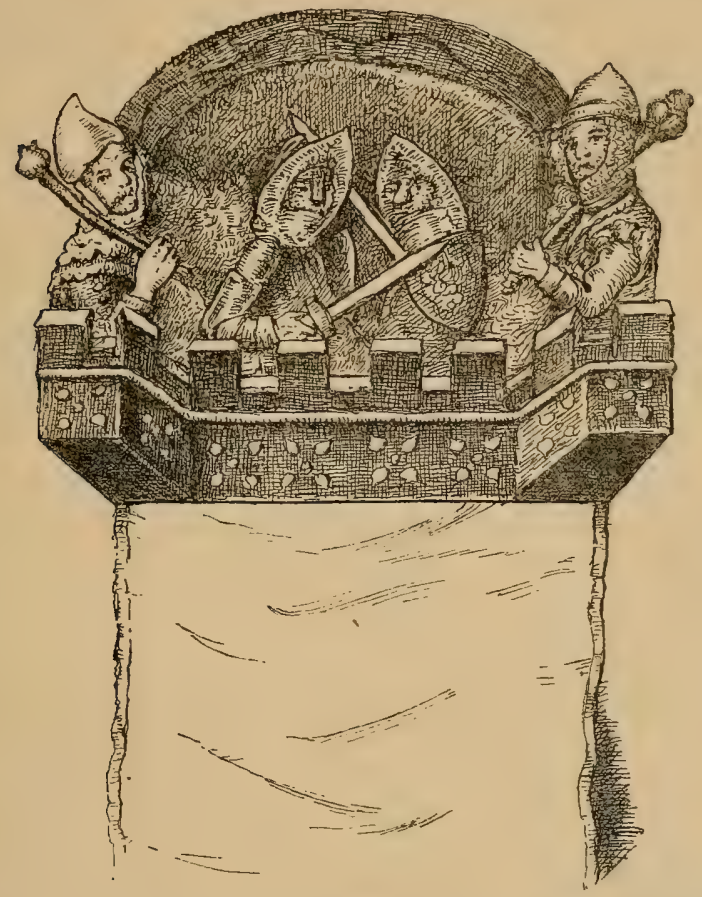

FIGURE 152.-A fourteenth-century puppet-show (from the MS. of the "Roman d'Alexandre").

Chamber of St. Germain or in the Louvre. The hump in front, he says, was derived from the protuberance of the heavy cuirass. This is much the same explanation as that which we have already given, though the cuirass probably stuck out in front of its wearer even more than did the doublet.

There is no doubt but that the French like gayer dresses than the Italians, and we have seen that even in I630 the clothes 
of Harlequin, Pantaloon, and Scaramouch in Italy were, like those of Punch, plain and simple; but in order to be popular in France, the Pulicinella had to dress in a

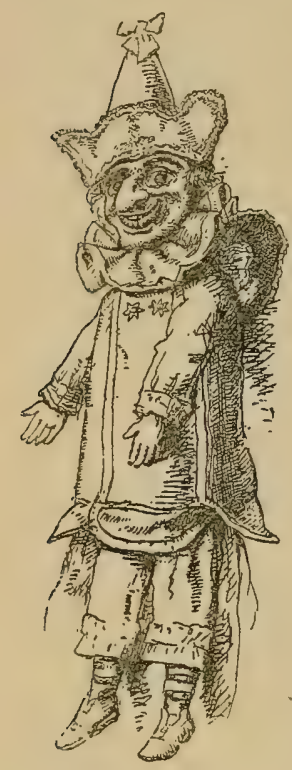

FIgURE I53. Punch, from the Punch and Judy Show, showing the ruff and other details of Elizabethan costume. new style, and it is known that already in I649 the puppet-show of which he is the hero had set up on the left bank of the Seine, opposite the Louvre. When Punch got to England it was at a time when gay clothes were worn, and some relics of these he has retained to the present day.

Red and yellow play a considerable part in the dress of the Punch figures used by Mr. W. H. Jesson, the members of whose family have for generations been performers of Punch and Judy, and who is one of the few that are still left. Punch has a very high cap of antique appearance, with turned-up brim and a bow of ribbon on the top. The hump on his back is almost horn-like, and forms a complete circle. It seems unlikely that this appendage was developed from any part of costume unless it were perhaps the liripipe; but we may rather imagine that in the past Pulicinella may have been represented as being a hunchback, and certainly Figure I5I, taken from the statuette mentioned previously, suggests an individual suffering from such a deformity.

Punch also wears a ruff (see Figure I53), though it is not a separate part of his costume, as in Judy's case, where it is of lace and its character is well shown, as it consists of more than one thickness. Judy's head-dress is the mob cap which was fashionable in the time of George III. (See Figure I54.)

The beadle, with his three-cornered hat and his brightly trimmed coat and cape, has survived for a century or so after 
his clothes first became fashionable, and no doubt in the puppetshow he will persist for many years when every living representative of his kind has passed away. (See Figure I55.) Of two more characters we have a word to say,-in the first place, of the doctor, who is brought before us in clothes of almost clerical cut, which remind us of the fact that the members of the medical profession were once more easily recognized by their dress than they are now (see Figure I56), in the second, of Toby, whose sole costume consists of a ruff.

Though Punch has donned new clothes and altered his habits to suit not only the countries in which he sojourned, but the times in which he has performed, yet despite these and other changes that have gone on since he set foot on these islands there is one thing that has always been his special characteristic. This is his squeaky voice, which he retained even in Molière's play, and it is from the peculiarity of his voice that he gained his name. Pulicinella means a "hen-chicken," which might well be expected to have a squeaky voice.

With regard to the changes in Punch's behaviour we have a word to say. Originally he was somewhat of a composite character, the constituent elements being derived from several of the personages of the larger theatre. At first, to the amorous and intriguing ways of Pulicinella there was added the roguery of Scaramouch, as well as the dash and braggadocio of the Spanish captain who was a member of the comedy company, akin to the Miles Gloriosus of Plautus and the Bobadil of Ben Jonson.

As time went on there was less

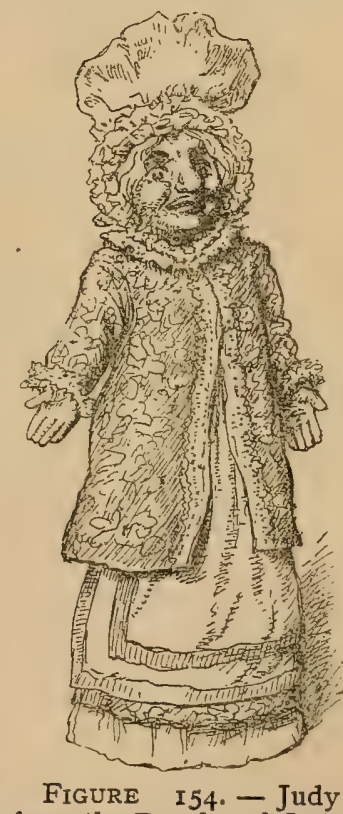
from the Punch and Judy Show, with ruff, mob cap and apron. 
love-making and trickery and more knocking about, but $\mathrm{Mr}$. Heppel will not allow that the French writers are right

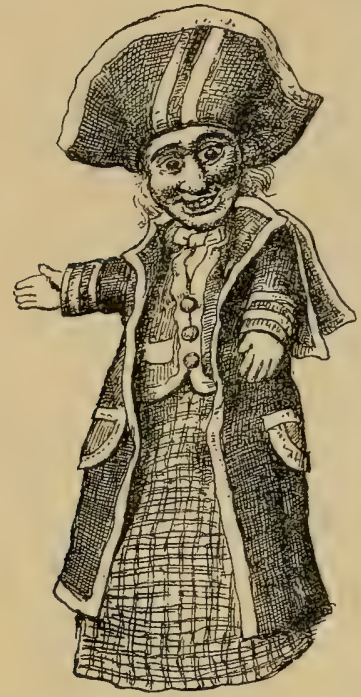

Figure I55. - The Beadle, from the Punch and Judy Show. in ascribing the whole of this to English influence. For the fact that the puppets are not alive gives an opportunity for dealing blows with a reality that could not be tolerated if the actors were living, and when we remember the way in which dog Toby seizes Punch by the nose, we cannot help feeling that the effect could hardly be so realistically produced on the actual stage.

In France, Punch is a bachelor, or if he is married he is not very much married, while in England Punch always runs in double harness. Another alteration has taken place. Polly, who was one of the characters that have disappeared, has departed for the reasons put into the showman's mouth by Mr. Henry Mayhew in I86I. "Miss Polly was left out, because it wasn't exactly moral. Opinions has changed. We ain't better, I fancy. Such things goes on, but people don't like to let it be seen now; that's the difference. Judy's dress, you see, is far different, bless you, than Miss Polly's. Judy's, you see, is bed-furniture stuff, and Polly's is all silk and satin. Yes, that's the way of the world; the wife comes off second best."

As in old times, there was much buffoonery introduced even into religious plays, and the characters which have been separated from the other performers to take part in the special harlequinade of the modern pantomime used, together with Punch, to appear side by side with those who took the part of religious personages. To uneducated people there seemed 
nothing profane about this; but as time went on men and women came to look at matters in a different light. For reasons somewhat similar, the devil and the ghost are now left out, and in the performances that are given in drawingrooms even the coffin, in some cases.

The connection, however, of Punch with religious plays probably accounts for the name by which his wife now goes. Those who mistakenly supposed that the word Punch was derived from Pontius Pilate looked upon Judy as representing Judas Iscariot. We have already pointed out the origin of the former appellation, which ante-dates the Christian era, while a difficulty is met with in the fact that the wife of Punch for many years was known as Joan. Mr. Heppel says that of the miracle plays some of the most popular were taken from the Apocrypha, and a very favourite subject was the tale of Judith and Holofernes. If we cannot find an instance recorded of Punch furnishing the amusement in this story, we can, at any rate, find an advertisement of a play in which Harlequin and Judith were together, and the comic business was sometimes entrusted to Punch and sometimes to Harlequin. Hence Punch and Judy may not improbably have come from Punch and Judith, while Toby naturally suggests the dog in the book of Tobit.

With regard to Toby, it may be said that he is represented in France by a cat, and that until the nineteenth century he was only a stuffed figure. In China, where Punch beats his wife to the music of the clarionette instead

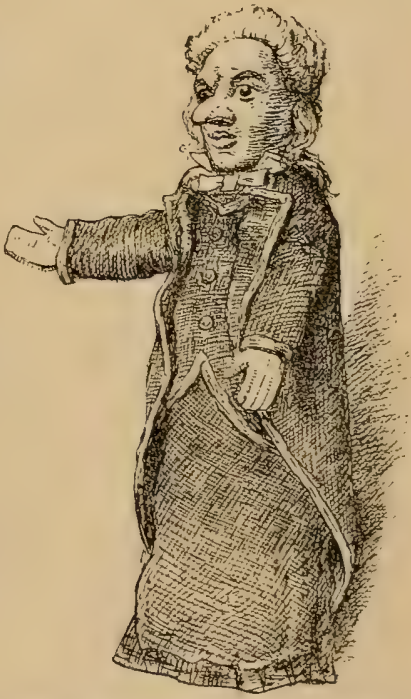

Figure I56.-The Doctor, from the Punch and Judy Show, with wig and white tie. 
of Pandaean pipes held in a muffler, Toby is replaced by a wooden dragon with jaws that snap, and this figure is also now used in England to take the place of the devil, who, like the parson, the ghost, and Jack Ketch, the hangman, is dying out. Hector the horse has quite disappeared. We might mention here that in the English version a clown is brought in with very considerable effect.

There is another connection of dolls with costume rather than of costume with dolls which we maymention at this point. In the fourteenth century, when there were no fashion plates, and written descriptions would hardly do their duty effectively, model costumes were put upon dolls and sent from country to country. It is, moreover, a curious and interesting fact that it was principally from Paris that these fashions were sent out.

Examples of national costumes sometimes survive on the bodies of dolls. The figure of St. Nicholas, in Belgium, shows an old dress, and the costume dolls of Holland, France, and Switzerland are excellent records of native dress now seldom seen in everyday life. Mr. Edward Lovett bought a little doll in Lucerne which is in a cradle, and shows excellently well the swaddling clothes that were formerly in use. Similar ones from Hungary have been previously mentioned. Ancient Greek and Roman dolls, taken from children's graves, were similarly dressed, and a modern Russian doll, which is also in the possession of Mr. Lovett, is shown with the swathing band in situ. The only dolls that are to be found in Malta represent ancient saints, and it is said that they are dressed as such.

The long garments of Noah and his sons in the toy Noah's Ark are worthy of mention and are an interesting survival.

A remarkable kind of doll is still to be met with in small toy shops. It is dressed in gay, parti-coloured clothes; is ornamented with bells and wears a high cap, while instead of legs it has a handle like a "fool's bauble" of old days.

The wrappings that were placed round mummies in ancient Egypt are shown on figures which were found in the tombs, 
and which are often seen as curiosities in this country. They were carved out of wood or modelled out of clay, while some of them were made out of the well-known glazed faience. They were put into the tombs in order that they might do the work of the deceased in his after life, and their origin is exceedingly interesting. Many barbarous nations have in the past sacrificed the servants of a chief at his funeral, and the Egyptians, who were humane people, contented themselves with a makebelieve, and replaced the actual persons with the figures that we call " ushabti," or, in modern parlance, " shabbies." 


\section{XXVIII}

\section{THE CLOWN AND PAINTING THE BODY}

THE CLOWN'S DRESS-SAVAGE PAINTING AND SURVIVALS OF. IT - TATTOOING - PATCHES AND FALSE COMPLEXIONS -MASKS

NO costume is perhaps more characteristic or better known than that of the clown; and it is of special interest, for while the hat was fashionable at the beginning of the fifteenth century, the dress, generally speaking, is a caricature of that which was in vogue in the time of Queen Elizabeth. The same remarks apply to the method of hair-dressing, and we shall see, when dealing with the other characters that appear in the harlequinade, that the pantaloon in his dress illustrates that of the same time in our history.

Unlike the other heroes of the pantomime, the clown is essentially English, and he is to be found also in the circus of to-day, at all times of the year, as well as on the stage at Christmas.

As to the clown's clothes, first of all there is the ruff, which is, however, not stiffened out. He has trunk hose or wide breeches which do not reach to his knees, his stockings are well ornamented with clocks; and lastly, there is the paint on his face, which brings us to a custom that seems nearly as old as man himself. (See Figure I57 and Plate X, Figure A.)

Among the relics of the ancient cave men of Europe are found hollowed stones, and these were used as mortars in which ochre and other colours were ground for painting the body. 


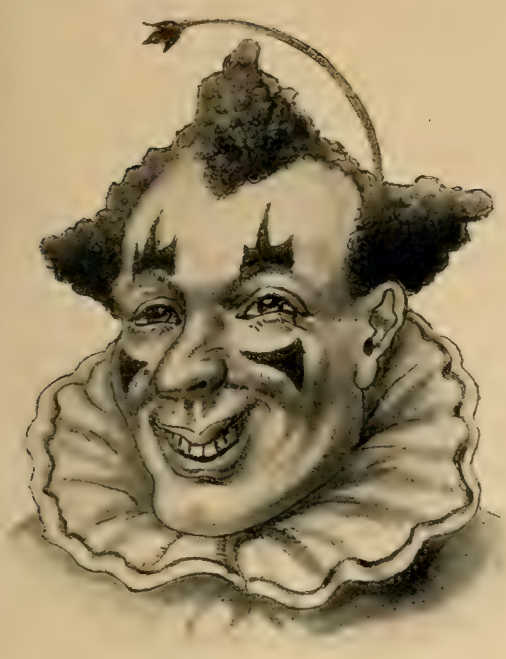

Figure A.

'THE HEAD OF A CLOWN, SHOWING THE PAINTED FACE, THE RUFF AND THE ELIZABETHAN METHOD OF DOING THE HAIR.

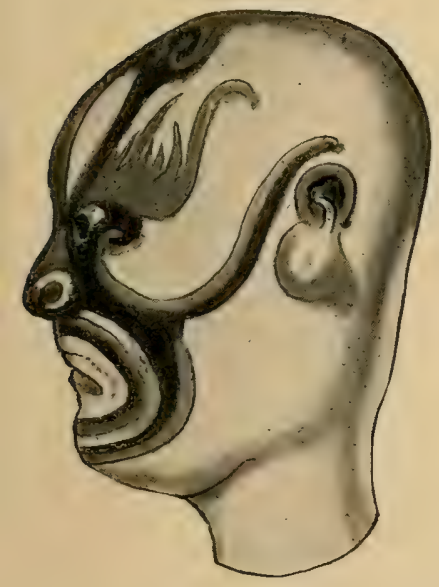

Figure C.

THE PAINTED FACE OF A PAPER FIGURE WHICH IS BURNED AT CHINESE FUNERALS.

(After Moseley, by the courtesy of Mr. John MI urrav.)

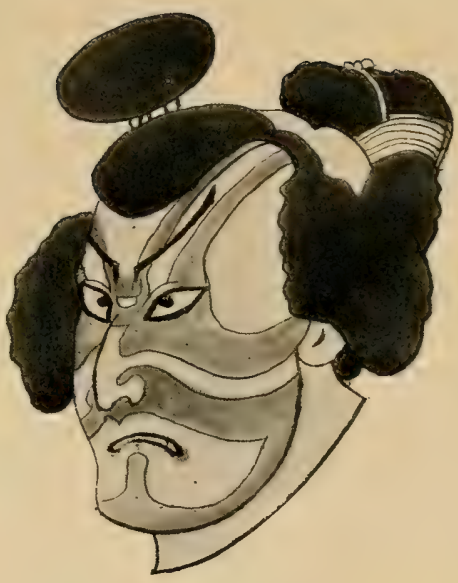

Figure B.

THE FACE OF A JAPANESE ACTOR. (After Moscley. by the courtesy of Mr. John Murray.)

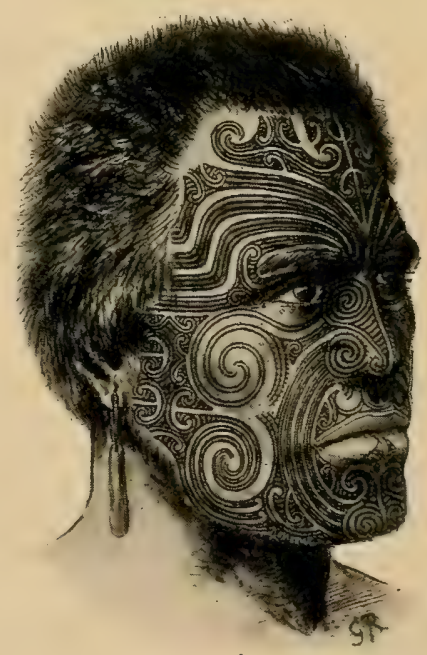

Figure D.

THE TATtooed Head OF A MaORI CHIEF.

(By the courtesy of General Robley.) 

The Egyptians still follow the practice of blackening the edge of the eyelid, both below and above the eye, with a black powder called kohl. The material is prepared either from burning an aromatic resin or the shells of almonds. The custom prevailed among both sexes in Egypt far back in its history, and -long before the historic period -painting the eyes was already practised by the-people whom Professor Petrie called the "New Race" (until he determined that they ${ }^{-}$preceded the dynastic Egyptians).

It may be well to point out that these prehistoric people lived about 6000 years B.C. : they had little or no metal, though they made most beautiful flint knives and stone vases. They buried their dead lying on one side with the knees towards the

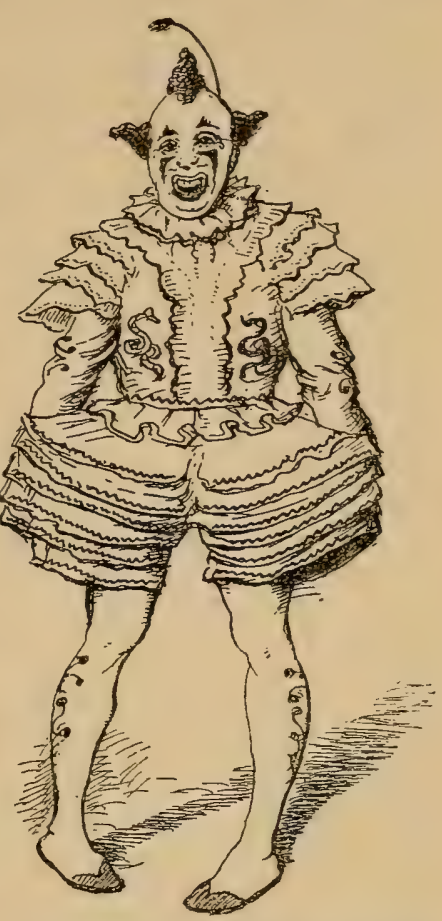
FIGURE 157.-A clown, showing
survival of an Elizabethan chin, instead of making mum-a survival
mies. Among the contents of costume. their tombs have been found curious slate palettes of all shapes and sizes, similar to some which had previously been known for many years, but the origin of which was undetermined. It has been shown that these palettes were used for grinding up malachite to form a green colour with which to paint the eye. The idea was, it is supposed, to mitigate the glare of the sun, and is similar to that which leads Anglo-Indians to have the under sides of the brims of their hats coloured green.

Another kind of temporary ornamentation is produced in Egypt to-day by staining the feet and hands with the juice of 
the leaves of henna. The result is that the part to which it is applied becomes a yellowish red or deep orange colour. The most common practice is to dye the tips of the fingers and toes so far as the first joint, the whole of the inside of the hand and the sole of the foot, and there are other and more fanciful modes of applying the henna, which is said to have an agreeable effect upon the skin, particularly in the way of preventing it from becoming too tender. The dyeing has to be renewed every fortnight or three weeks, and the stain is brighter and more permanent on the nails than on the fingers.

Among many native races in a low stage of civilisation there are few who do not decorate their body by painting it in some way. We have already mentioned that painting takes away the appearance of nakedness, and that many nations would be as much ashamed to be seen without their paint, as Europeans would be to walk about without their clothes. On special occasions, however, particularly striking colours are put on-for instance, by the Australians when about to dance a corroboree, and Professor Moseley ${ }^{40}$ has pointed out that they have breast stripes and leg stripes such as those which are seen on European uniforms. At first sight these, as Professor Moseley, indeed, points out, would appear to have quite a different origin, but it will be remembered that when speaking of the Hussar uniform and the Dutch skeleton dress (see page I05) it was suggested that the ornamentation might be intended to follow the lines of the chief bones of the body, and it is possible that the same idea may have underlain the painting carried out by savages.

In this case what in one instance was effected by paint was in the other done by means of trimmings.

Paint plays a great part in savage warfare, and no doubt the intention very often was to terrify the adversary. It is apparently this idea which actuated the old inhabitants of this country, who, as Cæsar says, stained themselves with woad in order to be of horrider aspect in battle; but Dr. Tylor 
has pointed out the error into which many historians have fallen through considering as savage races who, while having attained to considerable civilization, still kept up the practice of colouring their bodies in time of war. To the instances which we have mentioned of modern races staining themselves, we may add that of the Hindu women in India, who colour their teeth black and paint their feet scarlet. Japanese women blacken their teeth upon marriage.

In certain Japanese plays the actors have bright streaks of red paint made on their faces, usually on each side of the eyes (see Plate X, Figure B).

Professor Moseley ${ }^{41}$ records that the same form of painting is to be seen in the case of Japanese children on festive occasions, for after they have been elaborately dressed by their parents they are further adorned with one or two transverse and narrow streaks of bright red paint, leading outwards from the outer corners of their eyes, or placed near to that position. The style is the same as that which survives in the case of adults on the stage. Professor Moseley brings forward a further case showing that such a form of painting possibly existed in ancient times in China. When a man of distinction died in China in former times, a certain number of servants were sacrificed at his burial. Now, figures made of pasteboard and paper, about three feet or so high, are burnt instead at the funeral service in small furnaces provided for the purpose in the temples, together with cartloads of similar pasteboard gifts which are sent by the survivors for the use of the dead in the next world. Earthenware figures were similarly buried with great men in old times in Japan, and we may compare with these customs that of the Egyptians who buried models of servants, as mentioned on page I99, in the graves of their dead.

The pasteboard heads of these funeral servants and retainers are painted with streaks, some of which are put on in almost exactly the same style, at the angles of the eyes, as those of modern Japanese actors. It seems a fair conjecture that the 
streaks on these heads are a direct survival of an actual older savage form of painting which was once in vogue in China, and probably used to make fighting men hideous.

It is well known that primitive customs survive in connection with funerals all over the world with extreme tenacity. The numerous interesting survivals existing in the case of English funerals are familiar.

We give a figure taken from the head of a Chinese servant, which Professor Moseley bought at a manufactory of funeral properties in Hong Kong. (See Plate X, Figure c.)

With regard to the ordinary use of paint by women in China and Japan, Professor Moseley points out that it is entirely different in principle from that in vogue in Europe. He says : "The use of paint as an ornament in China and Japan seems to me to be of considerable interest. In both countries the women regularly paint their faces when in full dress, of which the paint is a necessary part.

"The paint is not put on with any idea of simulating a beauty of complexion, which might be present naturally, or which has been lost by age. The painted face is utterly unlike the appearance of any natural beauty.

"An even layer of white is put on over the whole face and neck, with the exception, in Japan, of two or three angular points of natural brown skin, which are left bare at the back of the neck as a contrast. After the face is whitened, a dab of red is rubbed in on the cheeks, below each eye. The lips are then coloured pink with magenta, and in Japan this colour is put on so thickly that it ceases to appear red, but takes on the iridescent metallic green tint of the crystallized aniline colour.

"In modern Japanese picture books, the lips of girls may sometimes be seen to be represented thus green. I suppose the idea is that such application of paint shows a meritorious disregard for expense. It is curious that the use of aniline colour should have so rapidly spread in China and Japan. 
In China, at least, such was not to be expected ; but it seems to have supplanted the old rouge, and it is sold spread on folding cards, with Chinese characters on them, at Canton and in Japan. This form of painting the face seems to be exactly of the same nature as savage painting."

The likeness of this painting to that of our clowns is of course quite obvious.

Sometimes the painting of the body has a practical advantage. The Andaman Islanders plaster themselves with a mixture of lard and coloured earth, which protects their skin from the heat and mosquitoes ; but, as Dr. Tylor points out, they go off into love of display when they proceed to draw lines on the paint with their fingers, or when a dandy will colour one side of his face red and the other olive-green, and make an ornamental border-line where the two colours meet down his chest and abdomen.

Fashions in paint were quite as slavishly followed as any other, and, as we see, have died hard. It is not a very far cry from painting to tattooing. Of savages, Théophile Gautier has said that, having no clothes to embroider, they embroider themselves. Scar tattooing is connected with various rites such as are followed when a brave arrives at manhood, and certainly tattooing serves to indicate the family or tribe to which the ornamented person belongs. There is no doubt, however, that the intention of much tattooing is to increase individual beauty. Excellent examples of this are to be found in the case of the Maoris, whose faces were most elaborately covered with designs. We are kindly permitted to reproduce some of the drawings which General Robley has made from specimens in his magnificent collection (see Plate X, Figure D). The practice now, however, is dying out. Of the Formosans it is said that their skins are covered with flower patterns until they look like damask.

Tattooing was practised by the old inhabitants of this country, by the Jews, and the earliest Egyptians : it is still 
carried on in modern Egypt, chiefly on the chin, on the back of the hands, the arms and feet, the middle of the bosom, and the forehead. It survives principally in the case of the women of the lower classes and in the country. Among European sailors and among the lower classes, and even occasionally those up in high social scale, we find tattooing carried on, though the original idea of ornamentation is lost when the decoration is covered by clothing.

We have seen occasionally at shows-such as that organized by Barnum-white people who have been tattooed to a very great extent, and even in the case of Europeans the patterns tend to take off the bare look even of the white skin. No doubt the desire to make permanent such ornamentation as that obtained by painting, led to the introduction of tattooing, and just as some marks suggest that they are copied from amulets so some amulets show traces of having been derived from tattoo patterns. Mr. Lovett has pointed out to us that possibly the floral designs worked on the backs of the bodices of the women of Markan, in Holland, may have originated from tattooing, but no doubt careful research would show some other and undoubted instances.

The painting of the face, which is intended to heighten its beauty and hide the ravages of time, is quite another matter. It survives to the present day, but luckily it is much less common in this country than it was a few years ago. It does not, however, seem to have been at all in vogue in England until the Middle Ages, though cosmetics and false complexions were made use of by ladies in Roman times.

Fairholt ${ }^{42}$ quotes from an old French poem of the thirteenth century which describes the wares of a mercer who declares, "I have cotton with which they rouge, and whitening with which they whiten themselves." The cotton took the place of the hare's foot that is now used in making up, to rub colour on the cheeks.

At this point we might consider patches, the use of which 
made it possible to ornament the skin with patterns that could be removed at will. These patches came into fashion in Charles I's reign, but were banned by the Puritans. As soon, however, as Charles II came into his own again, they made their appearance once more, and took various fantastic shapes: owls, rings, crescents, and crowns; a coach and horses was particularly fashionable, and in the time of Queen Anne it was possible to tell the political views of fashionable ladies by their faces and their fans. Party feeling ran very high at this time, and those who were neutral wore patches on both cheeks, a Whig lady on the right side only, while a High Church Tory dame only adorned the left, and she wore suspended from her wrist a fan on which was depicted a scene from the trial of Dr. Sacheverell at Westminster Hall.

Red and white paint was at the same time universally employed by women of fashion, who, as Miss Helen Gordon ${ }^{43}$ says, had perforce to keep their lovers at a respectful distance, lest a kiss " snatched by a forward one might transfer the complexion of the mistress to the admirer." The untimely decease of more than one famous beauty was attributed to the paint with which she besmeared her countenance, a notable instance being the death of Lady Coventry, whose husband had been wont to chase her round the dinner-table in his determined efforts to remove the deleterious compound from her face with his serviette. According to Walpole, Lady Mary Wortley Montagu used the cheapest white paint obtainable, and left it so long on her skin that it had literally to be scraped off. It may be inferred that these fine ladies rarely washed; but " the age was careless in that respect, personal cleanliness at a discount, and the essence pot consequently in great demand."

We spoke just now of fans, which can, perhaps, be considered an article of dress as they are very often fastened to the person. There seems no doubt but that at first fans did not close, and were made of feathers like those still in use in the East from 
whence they are derived. Probably in the beginning, leaves were used as fans, and palm-leaf fans are still to be seen. Fans were in general use in the sixteenth century, and the folding one appeared in the next.

Sometimes, as at the end of the eighteenth century, large green fans, called sunshades, were used out of doors in the same way as a modern parasol now is. There is another use of the fan still to be noted in China, namely, for blowing up a fire, and from this we no doubt get the expression of "fanning the flame."

Painting apparently was not only practised by women, for male courtiers at the end of the sixteenth century occasionally coloured their faces. If we are to believe some of the writers in the newspapers of to-day, men of leisure are not a whit better nor less foolish now.

Of masks as an ordinary everyday addition to costume we have no survivals, except in connection with some balls and an occasional burglary; but masks such as we see on the 5 th of November will remind us, like the face of the clown, of primitive face-painting, and also of the many curious head-dresses and masks which savages wear at certain ceremonies and dances. It is easy to produce grotesque effects by means of masks, and the discomfort that would arise from the paint is thereby avoided.

The practice of wearing masks, and indeed dominoes, by private individuals came from Venice. In the sixteenth and seventeenth centuries masks made of black satin and velvet often formed part of the toilet of society ladies. At one period the wearing of them was restricted to the times of carnivals ; at another, the nobility alone were allowed to use them, and now we only see masks at fancy-dress balls. Of the unwritten laws that rule the wearing of the mask, Mrs. Aria says ${ }^{44}$ : "Whether worn privately or in public, its disguise has at all times and in all countries been respected as inviolably sacred. To the masked the greatèst extravagance of language 
and gesture is permitted. He is allowed to indulge in acrid personalities and proclaim scathing truths, which, even if addressed to the monarch himself, go unrebuked. To strike a mask is a serious offence, while in no class of society, however degraded, would anyone dare to unmask a woman. Yet another prerogative entitles the masked to invite any woman present, whether masked or not, to dance with him, etiquette decreeing that the queen of the land may not claim exemption from this rule. Dear to romance is the masked highwaymen, who flourished until the advent of railways robbed him of his occupation ; and a grim figure is ever the masked headsman." 


\section{XXIX}

\section{STAGE COSTUMES}

THE HARLEQUIN, PANTALOON, COLUMBINE, AND ACROBAT

WHILE Punch has left the stage and is now a puppet, some of his coadjutors are with us, for the harlequinade is still introduced into many pantomimes at Christmas, and special plays have been written in which these characters appear. The harlequin, who gives his name to what is now an interlude, was some thousand or two years back one of the important personages in the old Italian comedy which gave us Punch, and which we have already mentioned in a previous chapter.

Harlequin was versatile and many-sided, and he still keeps up his slap-dash character. It is true that harlequin does not now speak, any more than does the columbine, and we may trace the evolution of the Italian Mimi, or buffoons, into the Pantomimi, who were tragic actors. They, by means of certain well-understood signs and gestures, were able to play tragedies in the open air under conditions which would have prevented their voices from being heard. In some theatres also the actors were not allowed by the authorities to speak. Originally the harlequin was a mime. He had a shaven head, a sooty face-for the mimi blackened their faces like our modern niggers - he had flat, unshod feet and a patched coat of many colours which he derived from the ancient peasants of Italy. Blackening of the face is a general custom found also among 
Morris dancers, whose performances are relics of sacrifices at which it was not desirable for the celebrants to appear in their own personal capacity. Hence the disguise.

Some have seen in the wand of the harlequin a descendant of the rod of Mercury, and have sought for a prototype of the modern pantomime in pagan mysteries. In England, however, we have turned the harlequin into a magician, and his wand is perhaps the gilt wooden sword which belonged to the clown or fool all the world over. Now also we have the character in what Mr. Calthrop terms his tightfitting lizard-skin of flashing golden colours, for the patches on his rags have now given place to a symmetrical pattern (see Figure I58).

There have been many celebrated harlequins who have devoted their lives to

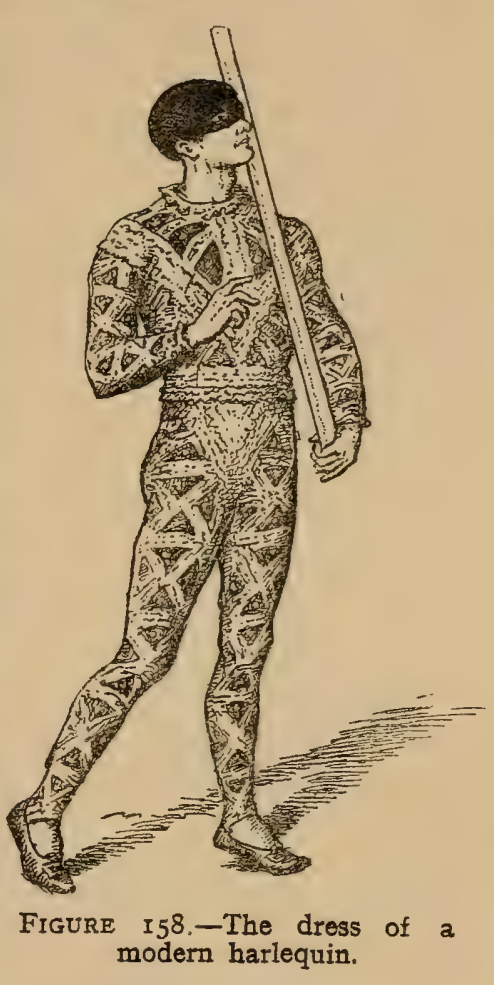
the development of this character, and there is an interesting case which Disraeli" gives in his "Curiosities of Literature," in which, as part of a quit-rent or feudal tenure -whenever the Abbot of Figéac entered this town-the Lord of Montbron, dressed in a harlequin's coat, with one of his legs bare, has to lead the prelate's horse by its bridle to the abbey.

In the clown and the pantaloon we still have the dress of Elizabethan times (see Figures I57 and I59). The paint on the former, as we have seen, will carry us back to times of remote 
antiquity. His hat is of a shape well known in early English history, and he himself is English all through. The pantaloon, again, is Italian. Both he and his Venetian breeches get their

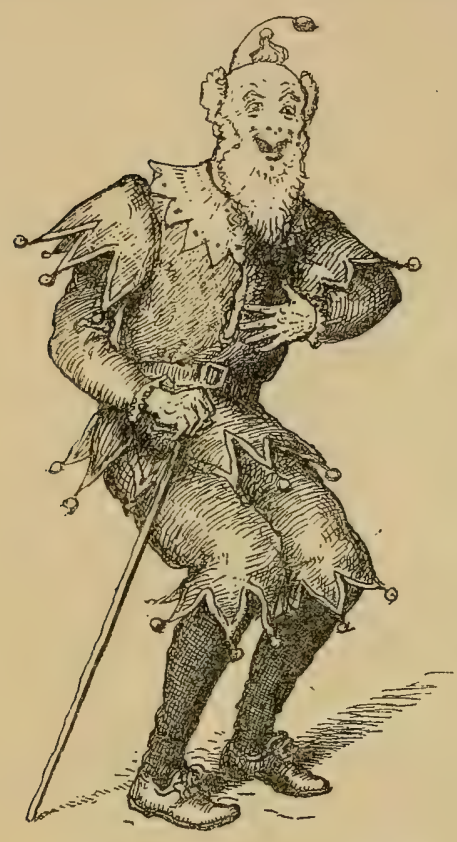

Figure 159.-A pantaloon, showing an Elizabethan costume of which Venetian breeches form part. names from St. Pantaleone, one of the patron saints of Venice. Pantaleone was by no means an uncommon patronymic in that place. In order to reconcile the statements that the dress of the pantaloon is Elizabethan and his nether garments are Venetian, which might appear to be mutually contradictory, it must be pointed out that the Venetian breeches had been introduced in the days of earlier Tudors, and were still in vogue when Elizabeth was on the throne. The pantaloon's red and green colours and his red heels are also, as we have indicated, Elizabethan.

The columbine, who, like the harlequin, does not speak, and so keeps up the pantomime character, wears the ballet dress of early Victorian times. Originally she was a female harlequin, or harlequinne, and her dress of spangles is still sometimes used in fancy-dress dances. Of the other characters, who once assisted those that we have described, we have none left. Scaramouch persisted for some time, and was, like the harlequin and columbine, a pantomimist. He has gone even from Punch and Judy, though the doctor still remains.

Though not strictly a theatrical performer, but seen in the circus, the music-hall, and still also as a wandering mountebank, 
we have the acrobat. His dress is simple and eminently suitable for the work which he has to do ; it consists of a vest, very short trunk hose or breeches, and long Florentine hose, or, as we now call them, tights. Though such a costume was seen in the reigns of the early Tudors, in detail the breeches are very much like those which were worn by Lord Darnley, the husband of Mary Queen of Scots. Doubtless also in the tights which are so familiar on the stage we have a survival similar to that seen in the acrobat, the clown, and the knights of the older orders. 


\section{$\mathrm{XXX}$}

\section{NIGHTDRESS}

\section{BANDS ON NIGHTGOWNS-NIGHTCAPS--NIGHT ATTIRE WORN IN THE STREET}

GOING to bed can hardly be called a ceremony; but the dress in which the bulk of humanity now sleeps can claim to be a special one. There are, of course, many people, who are not mere casual tramps, who sleep in their everyday clothes. Drovers who have to go to out-of-the-way places with cattle, where they can never be sure of getting a lodging, will sleep possibly after merely removing their outer coat, and it stands to reason that men engaged in this business can hardly be bothered to carry luggage with them. Any survivals that we may have to deal with in the case of our airiest dresses will not take us very far back into history, because our ancestors, from all accounts, went to an extreme which is the opposite to that which we have just been mentioning, and instead of keeping on all their clothes at night, they took them all off and put on no others. Mr. Calthrop ${ }^{46}$ graphically describes a scene which he supposes to be taking place in the reign of William Rufus. A lady is disturbed while getting ready for bed by a cry of "sanctuary," and watches from her window until the fugitive is let into the church by the monks. In concluding his story, Mr. Calthrop says, "The night is cold. The lady pulls a curtain across the window, and then, stripping herself of her chemise, she gets into bed."

A man's nightshirt is severe in cut like that which he wears 
in the day, and the sides are slit up in both garments as they are in the dalmatic and the tunics worn by the Anglo-Saxons, which were like a day shirt, and longer behind than in front. A survival of the latter as an outer garment is to be seen in the short smocks worn by labourers who dig drains and do similar work. The lady's nightgown may be elegantly ornamented with lace in the same

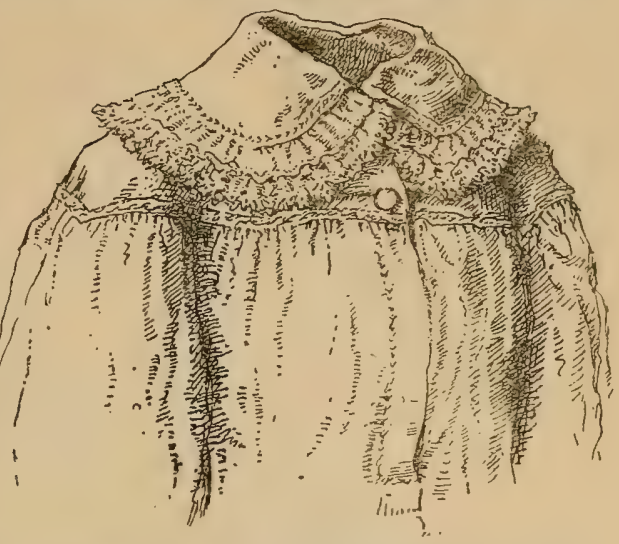

FIGURE I60.-The bands that survive on a lady's nightdress.

way as are the linen garments which she wears in the daytime; but very often we find a large collar edged with lace, which recalls the falling band which we have had so

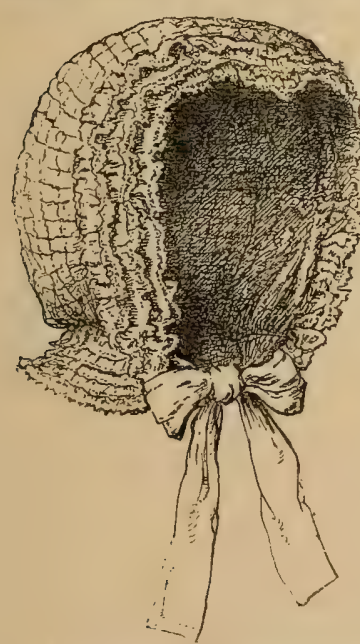

Figure I61.-A woman's nightcap, still worn in Wiltshire. often to mention. (See Figure I6o.)

To a great extent sleeping suits of a coat and trousers, which are known by the name of pyjamas, have taken the place of the man's nightshirt. These have the merit of making a man look more presentable if called up on an emergency. We shall see, if we contrast male and female fashions, that it has always been customary for the costume of women to follow that of men, though most ladies draw the line at adopting trousers. We have heard, however, of one young lady at least who does by night what 
she will not do by day, for she has given up her nightgown in favour of pyjamas.

Here and there we find that nightcaps are still worn. That belonging to an old lady, which we figure (see Figure I6I), came from the village of Bishopstone in Wiltshire, where no fewer than twelve old ladies, all of them over eighty, still wear. such a head-dress at night. Nightcaps were worn by men in the time of the Tudors, and that of Queen Elizabeth, as is shown by the following extract from a bill of 1547 : "Pd. for two nyght caps of vellvet for them, 8 s. od." 47

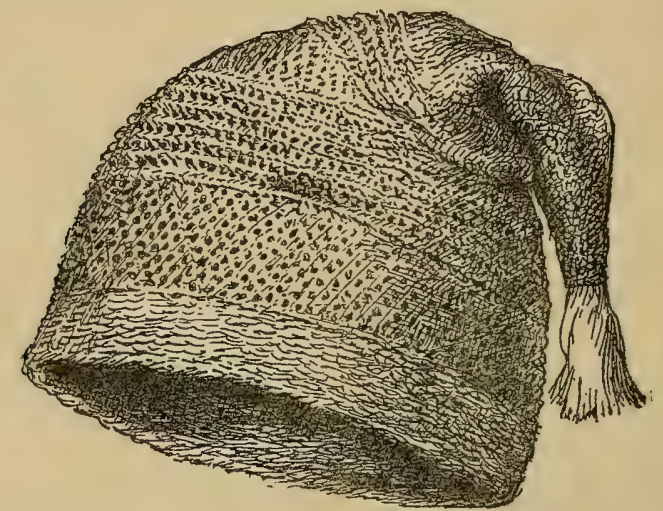

FIGURE 162.-A man's nightcap, from Oxfordshire.

They were very elaborately embroidered at this time, and in Mary's reign were mentioned in a sumptuary law. Old men still wear nightcaps, and the one we figure was used until lately at South Stoke in Oxfordshire. It is of the familiar style that we associate with such a head-dress, and has a tassel on the top. (See Figure I62.)

In the time of Queen Anne ladies wore their night-dresses, or night-rails as they were called, in the streets, and the fashion seems to have been in vogue at later times, though every means were taken to try and abolish it. It was not until a murderess was persuaded to appear at her execution in a bedgown that the fad was relinquished. 


\section{$\mathrm{XXXI}$}

\section{THE DRESS OF ANIMALS}

NATURAL REPRESENTATIVES OF CLOTHES-HORSE TRAPPINGSAMULETS ON HARNESS-DOGS' DISGUISES-FASHIONS IN THE FORM OF ANIMALS

HERE and there in the animal kingdom we find that H creatures protect themselves from injury by building up cases and coverings from extraneous materials, and these may very well be compared with the armour and clothes of mankind. Protection may be gained by merely securing something ready made to take the place of a coat, as is done in the case of the hermit-crab or " soldier," which covers itself with the shell of some dead mollusc. The caddis worm, or larva of the caddis fly, builds its home of sticks and stones or twigs, and thereby not only preserves its soft body from injury, but also harmonizes with its surroundings, in the same way as does the soldier on active service in time of war.

To gain protection, also, some molluscs when building their shells introduce stones and other shells and corals into the edifice, so that they become indistinguishable from the seabottom on which they lie. Many caterpillars cover themselves with bits of leaves, and even with the help of silk make spiral shells that might easily be mistaken for those of snails. The silk also, from which many of our gay clothes are made, is spun by the silkworm, which, like the larva of many moths, produces it in order to protect the chrysalis while it rests. 
We are occupied here, however, with the coverings of animals that they owe to man, and first and foremost of those creatures which have come in for his polite attentions is the horse.

We may recall the armour by which the chargers of the old knights were protected, and the trappings or emblazoned coverings that were put over this in the same way as the surcoat was made to cover the armour of the knights. (See Figure 84.) The trappings were often made of coloured satin, and were embroidered with gold and silver, and at the exhibition held by the Burlington Fine Arts Society in I905 a chasuble of red velvet was shown, embroidered with the arms of England in gold, which was apparently made from a horse-trapper of the fourteenth century. Figure 84 well shows how the horses carried the armorial bearings of their masters.

In the ostrich-feather ornaments and the velvet trappings of modern funeral horses, we still have some remnants of the days of chivalry.

To-day horse clothing, though not intended to be of an ornamental character, we should imagine, is still often decorated with a monogram of the horse's owner.

Perhaps one of the most interesting survivals in connection with horses is to be found in the brasses which decorate those used for carts and waggons. Dr. Plowright ${ }^{48}$ has shown that many of these ornaments, which are really amulets put on to the harness with a view of protecting the horses against the evil eye, are of Moorish origin. He contrasts their style with the ornamental details shown in the Alhambra, and he figures a number which take the form of a crescent, or a crescent enclosing an eight-rayed star, and others in which the ornament shows eyes and eye-brows conventionalized. In other cases we get the fleur-de-lys treated in an arabesque way, the escallop shell and the mystic interlaced triangles (which were considered the talisman of talismans, and are 
known as the seal of Solomon or the shield of David), with a crescent in the centre. Miss Lina Eckenstein ${ }^{40}$ figures many other horse brasses which can be compared with those worn by Roman cart-horses. Among them is the crescent, which was also worn by women carved in ivory, and by certain senators as ornaments on their shoes.

The crescent is made from a thin plate of metal, and is worn by children on the west coast of India, with the points upwards, as a protection against the evil eye, and gold ornaments of similar shape are among those which were worn in ancient Peru.

The moon, from times of remote antiquity, has been represented by a ring for the full moon and a half-ring or sickle for the crescent. Miss Eckenstein does not, however, carry the origin of the horse amulets back to the stone stage of civilization, but she thinks that the crescent represents two boars' tusks joined together by a thong, and the horse-amulet now worn in Italy shows the thinness and sharpness of curve that would be evident in one which was made out of boars' tusks.

We may point out that in some English crescents the hollows which one tusk makes by wearing against its fellow may possibly be represented by little flat places on the horns of the crescent near their tips. (See Figure I63.) The use of the horse-shoe to ward off the evil eye is due apparently to its crescent shape.

The brasses seen in England to-day are worn on the faceplate, breast-plate, and martingale. On grand occasions, such as May Day celebrations, and the cart-horse parade of Whit Monday, brasses are specially put on, though there is a tendency now for them to be stamped out of thin metal instead of being cast, with the result that they soon wear out. German horses wear the crescent on a strap which dangles below the right ear.

The English crescent from harness will be found to match 
those which are represented on the horses on Trajan's column and other monuments. The same design is to be seen also

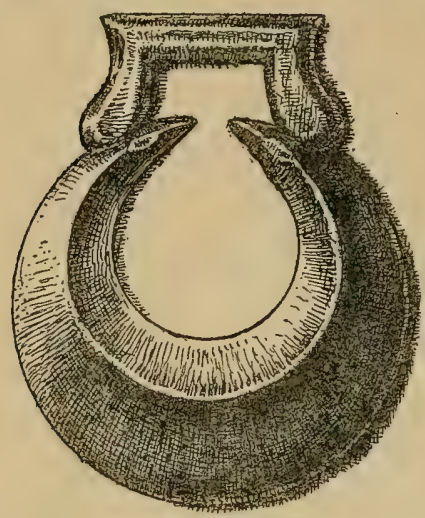

FIGURE 163.-An English horse amulet in the form of a crescent. Probably derived from two boars' tusks. on the harness of camels and elephants. The most important symbol besides the moon is that of the sun, which is worn on the top of the head between the ears.

Heraldic brasses are not uncommon, and the heart-shaped amulet is also seen; it is possible, too, that this form may be connected with that of the flint arrows, which we have already mentioned as being worn as amulets. In Egypt, an amulet hung on a cow is said to protect the woman who owns it, and Miss Eckenstein suggests a similar origin in the case of the heart worn by horses. A brass showing a horse rampant, came from the estate of the Duke of Norfolk at Arundel, and it will be seen on looking at the arms of the nobleman in question that this device forms one of the supporters of his shield.

In prehistoric Egypt the slate palettes on which malachite was ground for face painting were often in the form of two birds, with their bodies put back to back, and their heads fully shown, and when this form degenerates it becomes a kind of heart-shaped shield. Professor Petrie has pointed out that when this

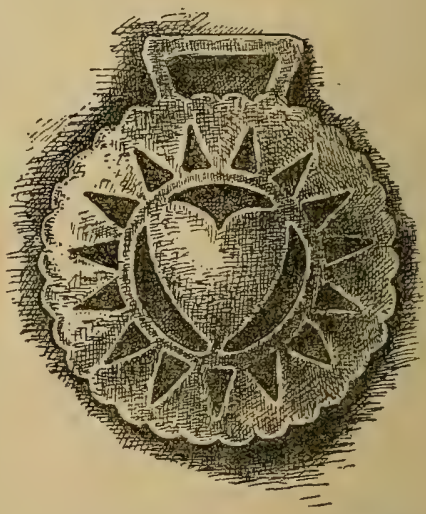

Figure I64.-An English horse amulet showing both the heart and the sun. 
decoration is used, as on coffins and elsewhere, it is often thought to be merely a shield. Possibly the heart-shaped amulet may have some connection with this.

An amulet found by Professor Vellucci in Umbria consisted of an arrow-head sewn upon a piece of scarlet cloth, which was of a heart shape, and was intended doubtless to emphasize the heart significance. Another horse amulet, obtained by Miss Eckenstein from Sicily, also consists of a piece of scarlet cloth cut into the shape of a heart and decorated with tinsel.

An English horse brass seen in Figure I64 shows both the heart and the sun.

While on the subject of horses, one might allude to the wisps of straw which are twisted in the mane and tail of cart-horses when they are for sale at markets and fairs. Horses were sacrificed in the old days; and as the slaying of domestic animals was supposed to secure fruitfulness, the horse became identified as a corn spirit, and the killing of horses formed a necessary incident of the harvest. The deity Demeter took upon himself the semblance of a mare, and the word mare is applied in the Midlands to the last uncut ears of corn, at which the sickles are thrown in order to bring them down. It is possible that the wisps of straw worn by horses are connected with these ideas.

A very curious and interesting custom is represented on the trappings of the horses ridden by the officers of the Ioth Hussars. These trappings are ornamented on full-dress occasions with cowry shells; and to find a parallel to this we have to go to the East, where the head-stalls of the camels and mules are covered with the shells, while round their necks and those of donkeys there may hang an ornament or bell on a band which is similarly decorated. It will be noted that there is a pendant from the head of the Hussar horse which resembles that of the mule of the Holy Land. There is no doubt but that originally these ornaments were really amulets, 
and it is said that they are a survival of ancient phallic worship. (See Figures $165-7$.)

Cowry shells were once generally used by the Hussars, and were revived in the case of the Ioth Hussars in connection with service in India.

Toby, as we have seen, is decorated with an Elizabethan ruff, but the wearing of collars and bells by pet animals is a remnant of a very old custom, and on early mediæval brasses

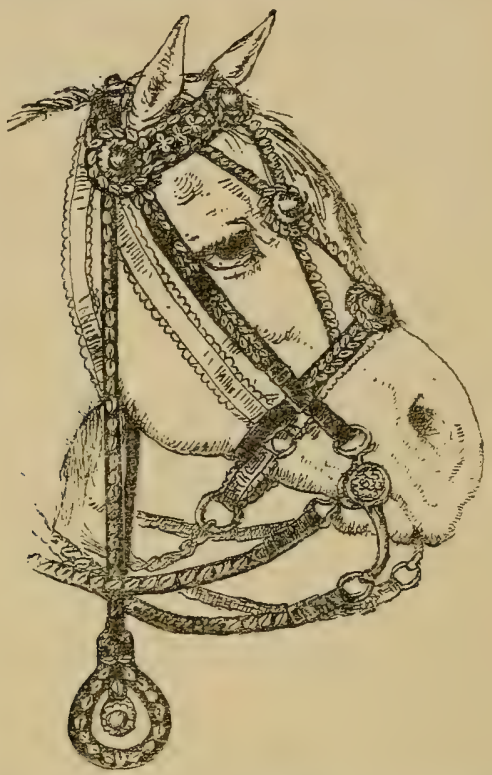

FiguRe I65. - The cowry-shell crnaments on the head of an officer's charger of the roth Hussars. The pendant recalls that on mules in Palestino.

in this country, dogs are often seen decorated with collarssometimes bearing their actual names-and with bells. Now the wearing of a collar is enforced by law as a means of identification. All dogs found without collars may be considered as strays, and the regulation followed, as is well known, upon the muzzling order by which hydrophobia was practically stamped out. 


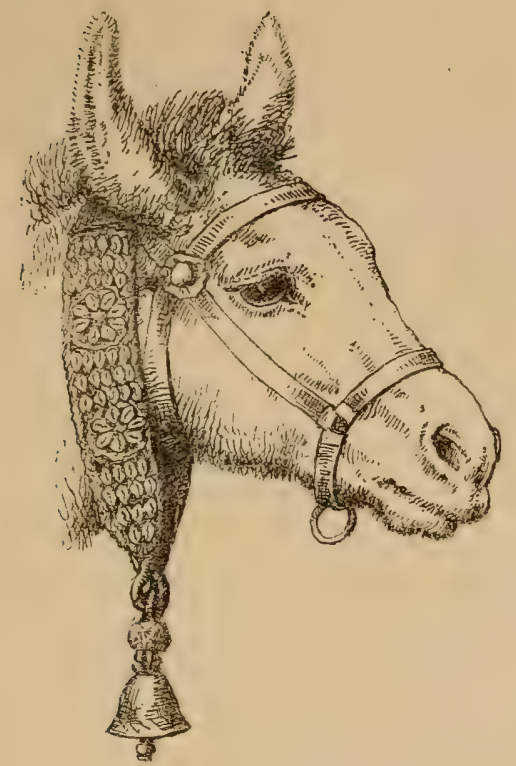

FiguRE I66.-Cowry shells on an Eastern mule, hanging like the pendant of the Ioth Hussars.

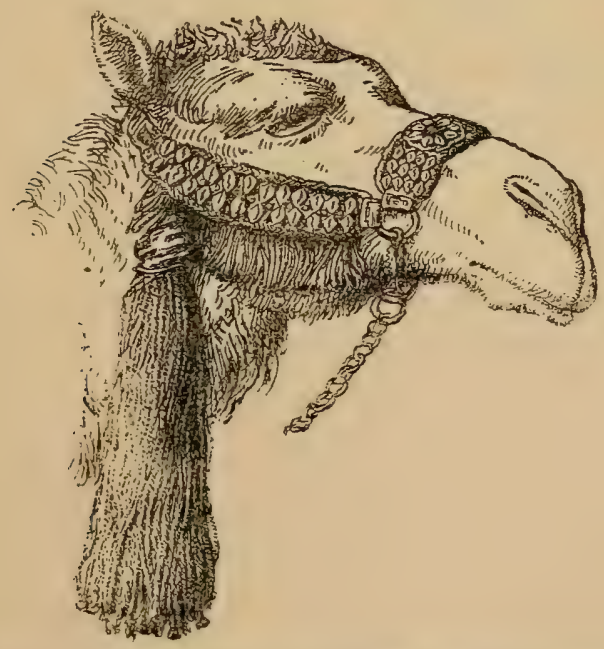

FIGURE I67.-Cowry shells on the head-stall of a camel from Palestine, 
Mr. C. J. Cornish ${ }^{50}$ once considered the subject of animals' clothes, and made some interesting remarks on horses' hats and sun-bonnets. He described the following sight, met with in Kensington Gore: First came a costermonger with his horse duly "hatted" and the hat trimmed with ribbon; next came a lady wearing a hat, in a victoria. Her horse also had a hat, and both hats had pink flowers in them.

In Holland, cows wear rain-proof jackets all the winter, and coats for show cattle are quite the fashion in England. Mr. Cornish says that a really smart Jersey cow would not like to be seen at a show without her luggage- " a chest containing not only her sleeping jacket, but her brushes and combs, cosmetics, and horn protectors. She puts on, or has put on, a smarter jacket in the daytime if she has to stand in a draughty place; if she is not sleeping out it does not so much matter. There are many ladies who would almost go without a jacket themselves rather than see their best animals go to a show without proper clothes."

In the North, lambs are provided with waterproof coats when going on to the hills. These garments are called " brats," and the name has been transferred not only to the young sheep themselves but also to human babies. We are all familiar with the clothes which monkeys wear when they go about with organs, and the big apes which are exhibited at shows are sometimes even clothed in the dress suit of conventionality. Johanna, the chimpanzee which was at Barnum's exhibition, looked very effective in her petticoats, and the penguins at the Zoo, when performing tricks, wear coats, while animal actors are often dressed to suit their parts.

There is one case at least in which animals are disguised by dressing them up. There was a duck-decoy dog which was known to Mr. Cornish, which, in the first instance, grew as much like a fox as it was possible for a dog to be. This proved exceedingly attractive to the ducks, which seem to have an irresistible impulse to swim after $a^{\prime}$ fox in order to see what he 
is about. In a short time, however, they get used to a particular dog, and their curiosity dies away. Then the dog's master supplies him with a disguise in the shape of a jacket made of sheepskin. Furthermore, when this palls, a rough woollen jacket of a black colour is brought into requisition, and the dog apparently knows the meaning of the whole performance. In other cases the disguise of a decoy dog takes the shape of a foxskin with its brush.

Racing dogs, prize dogs, and pet dogs also have their coats, and we have heard even of bracelets for poodles, while there are fashions which regulate the way in which the hair of these dogs should be cut. Just as men and women deform themselves, so they mutilate their animals by the clipping of their ears and the shortening of their tails-practices which are worse than the dubbing of the birds' combs in the old days of cock-fighting, for the infliction of one slight injury probably prevented many.

This deforming of animals is a savage custom, for Hottentots twist the horns of their cattle and sheep, while a number of horns are produced in Africa by splitting the budding horns of the young animals. Though not obviously causing any deformity, there is one fashion which, though condemned by most people, is still followed by otherwise cultured and humane people. We refer to the bearing-rein with which horses' heads are kept in unnatural, uncomfortable, and constrained positions.

If, however, we consider animal fashions as a whole, and bring under discussion the colours and peculiarities of the fur or feathers that cover their bodies, we shall find that men from quite early times have amused themselves with producing all manner of curious and striking appearances. The fact is, that the ordinary conditions and dangers of life in the open, which would soon eliminate any creatures out of harmony with their surroundings, do not act in the case of domesticated animals very much; and this has been a help. We have, 
therefore, white rats, piebald mice, gold fishes-some even with several tails-yellow canaries, frizzled bantams, hairless dogs, hornless cattle, booted bantans, and top-knotted fowls, as well as hosts of patterns and forms that are hardly to be numbered. There is an adage that "like produces like," but the student of heredity has recently become aware of the fact that animals of a certain colour may not always produce offspring which resemble them in this respect; but that in order to get the tint required for show purposes, parents of some particular but unfashionable colour should be chosen.

The colour of animals is taken into consideration in connection with ceremonies. White elephants have to be treated as if they were gods, and proverbially cost much to keep. Black horses are usually used at funerals; white or grey horses, which are much decorated with the badges and insignia of the regiments, carry the kettledrums of the cavalry. The Scots Greys take their name from their horses, which are all grey, like those with which, it is said, they were supplied by William III in Flanders. Spotted Dalmatian hounds are those which are chosen to run by the side of carriages, while circus horses exhibit much variety of colouring.

Whips are perhaps a little beside the subject, though there are fashions with regard to them. Not long ago it was customary for the whip stick in connection with a smart turn-out to have a bend in it. In various parts of the East the camel driver carries in a graceful manner a red forked stick, and one of this form was used as a sceptre in ancient Egypt from 5000 B.c. downwards, so that we meet with a very interesting, if humble, survival of what was once a royal ornament. 


\section{XXXII}

\section{COLOUR}

INIPORTANCE OF COLOUR-INSTINCTIVE LOVE OF BRIGHT HUES-DESIRABILITY OF COLOURED CLOTHES AND GAY SCENES-COLOUR AND COMPLEXION

$I^{T}$ has been apparent throughout this book, as it is in Not only has it often a great significance, but its presence or absence must also have a considerable effect upon the minds of the people at large. One cannot help thinking that if women were to dress as a whole in the same quiet, or let us say solemn, tints which are characteristic of men in their everyday life, how much we should lose. Yet that there is a craving for bright colours is shown in every direction, and that they are attractive to those who do not themselves have an opportunity of wearing them is also obvious. The High Church clergy in this country make use of the coloured vestments that had developed in the Roman Catholic Church previous to the Reformation, and which have been proclaimed illegal.

The new universities vie with the older seats of learning in the colours which they choose for gowns and hoods. It is merely a question of expense which prevents the fancy-dress dance from being more common than it is. The pageants which have been held in various parts of this country, and the profits which have been made in many cases, bear out what we have said. Men, as shown by the red coats which they don for hunting and golfing, the colours in which they ride 
steeple-chases or play hockey, or the dresses in which they bathe, seek as far as possible during their leisure hour pursuits to go back to bright array.

Plays also are popular which are cast in the times when picturesque attire flourished or which borrow it from Oriental countries. The significance of colour is exceedingly far reaching. The ordinary Liveries of Royalty in this country are red; the red shirt of the followers of Garibaldi, the red cap of Liberty in the French Revolution, the red rose of Lancaster, call to mind great struggles. The platelayer, it is said, is instructed to wear a red tie so that on emergency it may be used as a danger signal. A red ribbon worn in the hair of a girl in some places on the Continent shows that she is engaged to be married, and it is with a red rag that the chulos in the bull fight enrage the bull. The term " born in the purple" alludes to this colour having been that adopted by emperors and kings in the past. Yellow is a favourite colour with gipsies; the women wear yellow kerchiefs and yellow beads, while the men favour yellow neckties. Mr. Yoxall ${ }^{51}$ points out that this colour was worn by mediæval Jews, and had a contemptuous or degrading significance. We have seen that yellow has been chosen as a mourning colour in Oriental countries, and possibly it was adopted on some particular occasion by gipsies like the black worms that we have mentioned in the lace of military uniforms, and has never been entirely left off since.

Among savages, yellow comes next in popularity to red, and it is said that young children are also fond of red, but are inclined to prefer yellow. The latter colour is not so stimulating as red, and this is well shown by the fact that the red light used in photographic works was found to cause so much mental irritation on the part of the workers that it has been abandoned in many cases in favour of orange. As regards the preference of older persons, it has been found that schoolgirls are more precocious than boys in the discrimination 
of colours, and never prefer orange to any other colour, yet they choose yellow rather than green, and usually than violet, but never prefer it to red or blue.

As age goes on, male students shift their liking towards the violent end of the spectrum which is the favourite one with men, while women keep to the red. Blue is associated in this country with the boat race held between representatives of the two old Universities of Oxford and Cambridge, and blue is usually taken to represent the Liberal side in political elections. The blue blouse of the butcher is characteristic, and, as we have found, is a still better instance of the survival of a trade costume than that seen in the case of servants. The colour, it is said, was chosen as blood stains are not so noticeable upon it as upon other tints. A black habit is that which the clergy adopt when not engaged in religious duties, while white has for centuries been used by them when conducting services. The same two colours, if we can so call them, are to be found in mourning, and to them a man is now restricted when he appears in ordinary Court or evening dress. The use of colour merely as a distinguishing mark without any deeper origin or special significance is so general that we shall touch upon it, and recall one or two instances with which we have previously met.

The gorgeous dresses of the Masons and the bright green scarfs of their humbler brethren, the Foresters, are further evidences of the love which civilized man still retains of dressing himself up. It is only but little less strongly developed apparently in him than it is in his children and in savage people.

We pointed out that red, although a special character of the British Army, is very far from being the universal colour of the uniform. We have had to deal with blue, buff, white, and black among the other colours that are to be seen adorning the bodies of our soldiers. The colours of heraldry no longer appear on our persons, except when we wear favours such as 
ribbons of red, white, and blue that come from national flags, and here we may recall that the standards of our regiments are called their "colours," and illustrate not only regimental but national history. The part that colour plays in the hoods and gowns of academical dress has on more than one occasion occupied our attention. Various coloured veils serve to differentiate the sisters of a religious order, while the ribbons and mantles of the knightly orders serve a similar purpose. It seems a great pity that at the present day the chapters or meetings of these Orders are seldom if ever held, and it would surely be interesting and useful, as well as enlivening, for certain occasions to be created on which the public might have an opportunity of seeing more of the dresses which have been handed down to our own times.

It is true that the King has of recent years opened Parliament in person, and glimpses may have been had of him in his state robes by a privileged few, but surely some opportunity should be found of having more pageants which are real and where there is no need for any make-believe. Besides having the advantages which we have urged would accrue from the bringing of a little more colour into our lives, such meetings would also have a practical result, and be exceedingly good for trade.

It is obvious that certain costumes, particularly the gay peasant dresses of the Continent, suit the style, complexion, and colouring of those who wear them. In races like our own, where we have all kinds of stages between the very fair blonde and the very dark brunette, the question of the choice of colours from an artistic point of view is important. There is also the question of surroundings to be considered, though nowadays it is not everyone who can afford the time, as the late Mrs. Haweis did, to visit the rooms in which she was invited to spend an evening, so that the colours of her costume might be arranged to harmonize with her temporary surroundings. 


\section{XXXIII}

\section{PATTERNS}

\section{ANCIENT DESIGNS-CHECKS AND TARTANS-PARTI-COLOURED CLOTHES-EVOLUTION OF ORNAMENTATION}

THE subject of patterns is a very wide one, and we shall content ourselves with mentioning a few to show how these have survived. When speaking of studs, we had occasion to mention the swastika or fylfot, which is probably the earliest known symbol. It is the forerunner of the cross, and it occurs on ecclesiastical vestments as well as civil clothes, and the well-known key pattern was derived from it. On Plate VII, Figure F, it may be seen on the shoulder of the Romano-Egyptian man, and its use seems to be almost universal. The pine pattern which we see on shawls is of Eastern origin, and it is said that it originally was taken from a map of some rivers in Cashmere.

Checks and plaids are among the commonest of our presentday designs, and the Gauls and those of our forerunners, who flourished at the time of Cæsar, wore breeches of chequered patterns. In fact, the very name of breeches is derived from " breac," which means striped or spotted, and in Gaelic also signifies the trout, which is speckled. Usually the ancient breeches showed a number of colours, in which, according to Diodorus, red predominated. Queen Boadicea wore a tunic apparently of plaid, the colours of which were a mixture of blue, red, and yellow. The real shepherd's plaid of Scotland 
is of a plainer character, being merely black and white, but it is in the special tartans of the Scotch clans that we find the system of coloured lines and squares carried to great perfection.

These tartans, as we may judge, date back to ages of which we have no record, but they have been used continuously in historic times. In the accounts of King James III of Scotland, in I47I, there are several entries with regard to money spent on tartans. The tartans, of course, were a distinguishing mark of the various Scottish clans, but sometimes, when attempts have been made to identify the patterns, confusion has arisen owing to the fact that many clans had more than one tartan; in fact, there may be the common clan tartan; that which was worn only by the chief and his heir ; a dress tartan; a fourth for hunting, and a fifth for mourning. For instance, while the dress tartan of the MacPhersons consists chiefly of black and white, with thin lines of red and yellow, the hunting tartan of the same clan is black and buff, with lines of blue and red. Similarly, in the Royal Stuart tartans, we find that the ordinary Royal Stuart has large red squares, the hunting tartan is mostly green and blue, while the dress Stuart has a large amount of white in its composition. There was, of course, a wonderful variety in colours, and it is interesting to note that all the dyes required were obtained from common native plants.

In England, after the Norman Conquest, there seems to have been little pattern used up to the time of Henry II, when diaper began to appear. Just as damask takes its name from Damascus, so diaper originally was derived from D'Ypres, meaning "of Ypres," a town which was noted for rich stuffs and fine linen. In Edward II's time pied cloth and particoloured silks came into vogue, while costumes of a particoloured character, which developed in the following reign to such an extent, were seen for the first time. Sometimes the whole dress would be symmetrically divided, so that half was of one colour and half of another. Again, the clothes 
would be striped in various directions, or one would find the right arm and left leg coloured blue, while the other two limbs were red. We get something of the same kind of ornamentation nowadays, as already noticed, in the dress of jockeys and the colours of athletic clubs, as well as in the case of the doll described on page I98.

In studying decorative patterns, the way in which some natural object has often become conventionalized is very interesting to trace, and if this is so in the case of art of civilized people, it is still more true of savage decoration. Our object is not, however, to deal with the evolution of ornamentation pure and simple, though we commend its study to our readers.

Turning to the Jews for a moment, we may recall that part of the adornment of the High Priests consisted of pomegranates and bells. The connection does not seem at all obvious, and Mrs. Finn has suggested that the bells are probably the flowers of the promegranate which have been conventionalized. 


\section{XXXIV}

\section{IMPRESSIONS TO BE GAINED FROM DRESS}

CLUES FROM CLOTHES-INDIVIDUALITY NOT DISGUISED BY THEM-MODERN DRESS OF OTHER COUNTRIES-SIGNIFICANCE OF CLOTHES

T F we turn our attention once more to clothes and their effect upon the outsider, there are questions to consider with regard to what may be judged from dress. First of all, as to the matter of social status, it must be confessed that it is very much more difficult nowadays than it was years ago to make any pronouncements from clothes, though it must be pointed out that there is a way of wearing clothes, quite irrespective of their kind, that will help us considerably in making a judgment.

The reason for the levelling up or down as the case may be is due, of course, to the standard of luxury having been raised and the price of materials for clothing having been lowered. As regards the determination of the profession of the wearer from his or her dress, it must be said that often we remain quite at a loss in the matter. Bearing and expression and general action may again afford a clue.

Characteristic costumes are now rare. We can tell the cleric as a rule, though some, especially those who have belonged to some other profession previously, will not adopt the collarless coat of black, the choker, or the white tie. 
Servants' liveries may be left out of consideration here, but the man that has to do with horses proverbially looks " horsey." To the list of uniforms to which we are accustomed there has been added of recent years that of the hospital nurse. The garb of various sisterhoods still catches our eye, and there are certain points which may help us occasionally in identifying a doctor, a lawyer, a schoolmaster, and an actor. According to a recent article by a detective in one of the daily papers, ${ }^{52}$ the characteristics and individuality of a man will show through his clothes, and the writer alluded to suggests the putting of a clergyman into a soldier's or a sailor's uniform or, again, the dressing of a valet in his master's clothes. "He will look quite different. He will give a fresh character to the clothes, and you will realize at once that he is a second-hand copy."

Mr. Chevasse says that if you walk down Oxford Street, Piccadilly, or through the City, you may pick out the ex-army officer, in his mufti tweed, for his instinct for dress is so ingrained that it is easy to recognize him. Mr. Chevasse would tell the fashionable physician from the following signs. His frock coat, scrupulously cut, his silk hat correctly quiet, which fit in with his sleek manners and the sang-froid of his superior knowledge. The dress dummy is another type-the man with the airs of a peacock, whose every article of dress is meant to attract attention. Of the actor whom one meets in the Strand, it is said that the odds and ends which he wears are typical of the parts he plays, but that his real individual character is not disguised as sometimes he might wish it to be.

In similar fashion we are given the points of the modern solicitor, of whom there are, we are told, two classes. The first type is dressed to exhale prosperity, and to convince the litigant that he is a safe man, but the character of his waistcoat will tell you more often than not that he robs Peter to pay Paul. The dress of other solicitors beams out sincerity, truth, reliability; the cloth is good and plain, and is well fitted to inspire trust and confidence. 
At the present time so many visitors from other countries, who are sojourning here for a while or have come to stay, are to be seen in our streets, that it may be of interest to see what the Editor of The Tailor and Cutter ${ }^{53}$ has to say upon the subject of their dress, or so far as that of the men goes. He says that, as a rule, in the case of the members of the aristocracy of all nations, their garments give the impression of having been made in London, and are free from the peculiarities which characterize those of other countries. Generally speaking, however, it is not difficult to tell the nationality of a man from his clothes. The American's garments are usually made two sizes too large for him. The collar of his coat is very narrow, and the shoulders and back, on the other hand, exceedingly wide. His jackets are often extremely long, his trousers are peg-tops, finished with raised seams.

In some ways the German is a modified American, though often there is to be found a seam up the front of his coat from the waist, as he likes plenty of room about his chest, of which he makes much. While the American, however, often has his coat finished in some extraordinary way which he fancies to be original, there is a lack of personality about the German, and the uniformity of his garments would appear to be the result of his military training. The American likes a lounge suit, and the German the same, or a morning coat, while the Frenchman favours the latter or a frock coat, which he has finished off with as much ornamentation as possible in the way of silk facings, braided edges, and fantastic flaps. His garments are close-fitting, and the waist is emphasized.

The Spaniard is like the Frenchman with modifications, for his garments are tasteful and neat, with few peculiarities. In warm weather he wears no vest, and his jackets are closefitting and finished with a low roll. In Austrian and Hungarian clothes French and German ideas seem to be skilfully blended, while Italian dress has more of the French than of the German characters. Norwegians and Danes are like Englishmen, 
though there is perhaps a little more preciseness and stiffness about their clothes. The colonial has no desire for show, and his tweed lounge suit is cut for comfort and made up for strength.

The impressions to be gained from dress that we have hitherto mentioned in this chapter are chiefly those which are unintentionally given to us by their wearers. The significances which it is meant that clothes should bear are still most numerous and important.

To-day, on ordinary occasions, rank is not shown by any special dress which those in high stations themselves wear, though the case of their servants is different. In earlier times in our history, especially under the earlier Tudors, rank was indicated in civilian dress. Now the frock coat worn by King and Peer is considered just as necessary in many businesses, and is characteristic of the shop-walker. Men of assured position can even afford to dress badly, though the poor man cannot.

Here and there we have met with survivals of class costumes (see pages I09 and 229), and to these we may add that of the costermongers, for in the dress of both men and women there are peculiarities which single them out.

In the same way we find remnants here and there of special dresses that are characteristic of trades. The blue blouse of the butcher, the white clothes of the butterman or man cook, and the white cap of the latter are cases in point; and in connection with certain duties and modern manufactures we have special dresses. We might allude to the overalls of furriers, feather merchants, and stationers. Divers, sewage men, and miners have special dresses, and boiler cleaners have a curious dress of coat and trousers made in one, which recalls one form of the military tunic used by the Norman soldiers, which sometimes ended in closely fitting trousers. It was first drawn on the legs, and the arms were then put through the sleeves. Such combination garments are shown in 
contemporary drawings, and it has been questioned whether these were really made in one piece, but the artist, though he might not indicate with certainty the openings through which they were put on, is hardly likely to have left out the lines which would have made clear a division at the waist.

At the present time in England there are very little differences in the costume of single and married women, though it was once compulsory for them to dress differently. The remains, however, of the custom are to be found in plenty of foreign countries.

In many professions rank is indicated by the dress or its ornamentations. In the Army and Navy, the Church, the legal profession, such points are obvious. We have had occasion to deal with academical costume, and in the knightly orders the same holds good. Just as an undergraduate has a stuff gown, while a graduate may have a silk one, a Proctor is given velvet sleeves and the Chancellor of the University an embroidered gown and train, so, for instance, in the order of Knights of the Order of St. John of Jerusalem, the Knight of Grace has a stuff gown, the Knight of Justice a silk one, while the Grand Prior is habited in velvet. 


\section{$\mathrm{XXXV}$}

\section{THE EFFECT OF CLOTHES UPON THE INDIVIDUAL}

THE ORIGIN OF STAYS-TIGHT LACING NO NEW THING-ITS EFFECTS-MR. HEATHER BIGG ON THE NEED FOR SUPPORT -THE IDEAL FOOT-SKULL DEFORMITIES-PADDING

$W^{E}$ have already seen (page 8I) that the human form may be directly mutilated in connection with the wearing of ornaments and in order to produce scars or tattoo marks which are considered to be embellishments and often in a way take the place of clothes, in so much as they do away with the appearance of nakedness. Now we may consider the distortions which are actually caused by clothes and bandages. There are cases, for which, as a rule, we have to look outside the confines of Europe, in which special contrivances are worn for a time in order to permanently alter the shape of some part of the body. Then, again, we meet among the races which claim to be most highly civilized instances which are not one whit less barbaric, but in which some article of dress is intended to cause or allowed to produce distortions, which satisfy the dictates of some particular fashion. It may be that an appearance of elegance or smartness is aimed at which may be the natural attribute of some persons and the envy of others, or a false idea of symmetry may lead to the same thing. 
The idea of altering bodily conformation is very ancient, but following our usual plan we will touch, first of all, on the modern examples of the custom before tracing the older ones. Not very long ago, and not for the first time in history, a great many women became imbued with the notion that there was nothing more desirable in this world than a wasp-like waist; and there are rumours, from time to time, even in the twentieth century, when it might be supposed that we were getting more sensible, that a similar madness is again about to overtake the gentler sex.

Now we may discuss the apparatus which has been degraded into carrying out the painful duty of producing an attenuated figure. The name stays indicates exactly the original intention of the clothing to which it is applied; but unfortunately something more than mere support has been sought after at various times since the classic period to which the beginnings of stays may be traced. The pair of stays which together form the modern corset-sometimes ignorantly and by false analogy supplied with an extra " $s$ "-is what is now used for purposes of compression. Proximately the idea is that of improving the figure, as it is called, and ensuring that it can be covered with garments of a fashionable shape. The ultimate results are about as bad as they can be, and it is not a question of opinion in this case, for the evil effects can be easily demonstrated. Sir William Flower ${ }^{54}$ refers to the practice as being " one of the most remarkable of all the artificial deformities produced by adherents to a conventional standard, in defiance of the dictates of Nature and of reason." He points out that in the process of deforming the skull, to which we shall allude later, the latter being a solid case with tolerably uniform walls, its capacity remains the same whatever alterations may be made in the shape, but in the case of the body it is quite another matter. It can, in fact, be well likened to a cylinder of fixed length which is closed above and below by a framework of bone, and circular compression must 
actually diminish the area which has to be occupied by some of the most vital organs. He goes on to say that the framework of the chest is a most admirable and complex arrangement of numerous pieces of solid bone and elastic cartilage joined together in such a manner as to allow of expansion and contraction for the purposes of respiration-expansion and contraction which, if a function so essential to the preservation of life and health is to be performed in an efficient manner, should be perfectly free and capable of variation under different circumstances. So, indeed, it has been allowed to be in all parts of the world and in all ages with one exception. It was reserved for mediæval civilized Europe to have invented the system of squeezing together, rendering immobile, and actually deforming the most important part of the human frame; and the custom has been handed down to, and flourishes in, our day, notwithstanding all our professed admiration for the models of classical antiquity, and our awakened attention to the laws of health.

The crusade against the corset is by no means confined to this country; even the educational authorities in America and on the continent of Europe have dealt pretty drastically with the matter. It has been stated, moreover, that the Queen of Portugal brought before the ladies of her Court the evils of tight lacing, by means of radiographs. There have been other times when even laws have been made with regard to the corset, which, it appears, was first employed for a wrong purpose in mediæval times. It is said of the time of Henry III of France that the corset was no longer the simple basquine that was inoffensive enough at first. ${ }^{65}$ The corps pique which was endured by the fair ladies of the period was an instrument of torture. A hard solid mould into which the wearer had to be compressed, there to remain and suffer in spite of the splinters of wood that penetrated the flesh, took the skin off the waist, and made the ribs ride one over the other. Montaigne and Ambrose Paré are witnesses, and the 
latter must have known something about the question. It is not, perhaps, surprising that Charles IX and Henry III brought in stringent laws on the subject.

We are told ${ }^{56}$ that with Catherine de Medici's ascent to the throne the habit became compulsory. She gave her subjects no choice, and said that all women of good birth and breeding should wear corsets which would reduce their waists to the abnormal size of thirteen inches.

In our country on various occasions lacing was carried to extremes, as in the time of Henry VIII. In Elizabeth's time, the forerunner of the busks was not fastened to the stays, but consisted of a piece of carved wood which was pushed down inside the bodice. (See Plate XI.) Some of the outer bodices in the times of the early Georges seem to be as hard and unyielding as if they were intended for armour. Tin stays were not unheard of in the days of the earlier colonists in America.

The craze for tight lacing once more made itself felt at the beginning of the nineteenth century, and not many years before the end one heard from time to time of the cruelty that was practised at high-class schools for young ladies, where the girls were made to sleep in specially tight and rigid corsets.

Although there is a tendency to abolish stays, it does not, of course, prove that on occasion they may not be of use. Mr. Heather Bigg, the well-known surgeon, who is a specialist in cases of spinal curvature, and who adopts mechanical means of treatment, ${ }^{57}$ is in a position to offer an opinion on the use of corsets, as he uses special ones as precautionary means of support and where curvatures may threaten, as well as to be safeguards against relapse after the mechanical treatment of a curvature has been consummated. In one of his books he has much to offer in favour of the corset, and at the outset it may be well to say that Mr. Heather Bigg's remarks are mainly directed against the views of the practitioner who, from the treatment that he advises, is called a, 

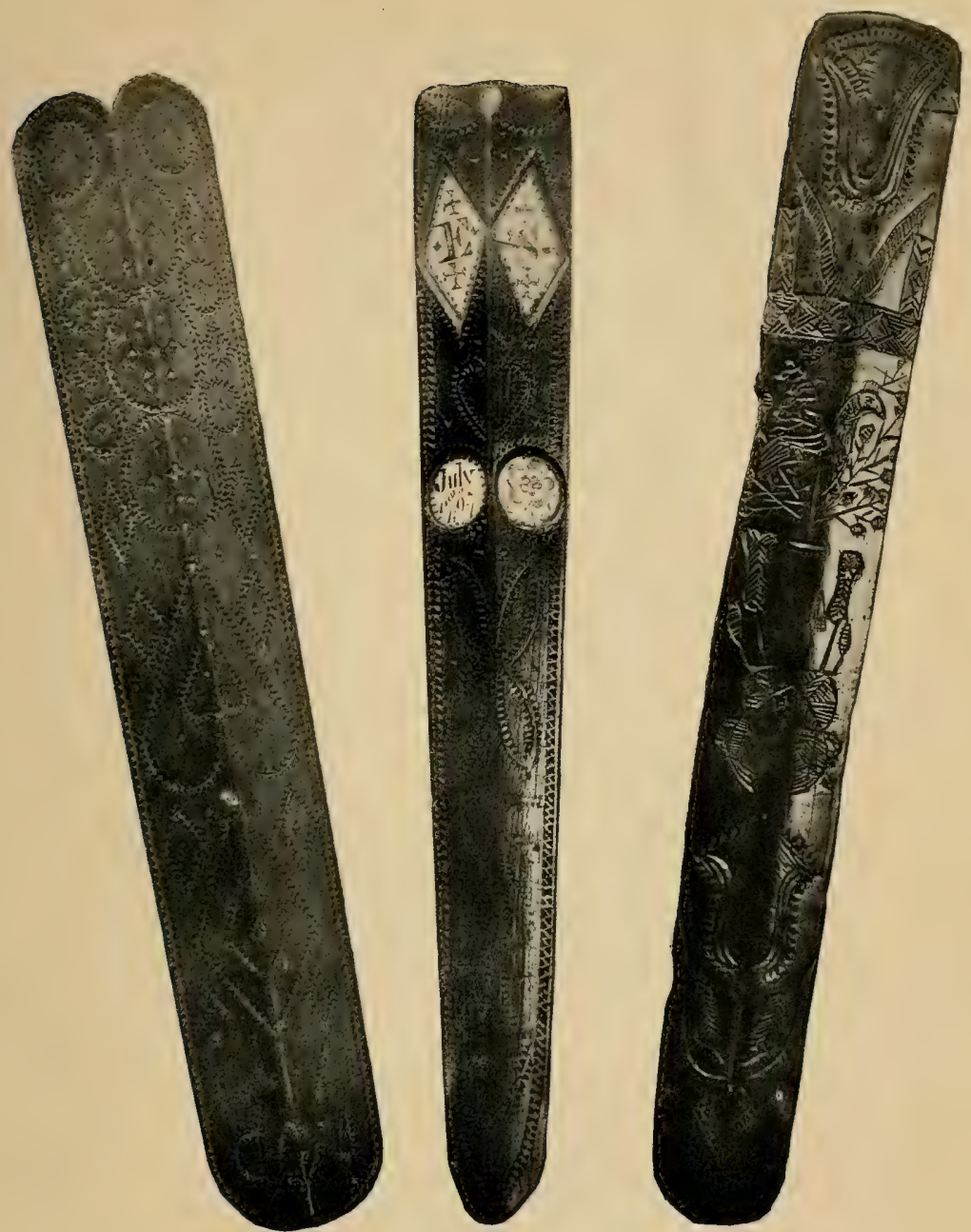

WOODEN STAY BUSKS. THESE INCIDENTALly SHOW SURVIVALS OF PRIMITIVE ORNAMENT. (See page 242.)

(From the "Reliquary," by kind permission of Messrs. Bemrose \& Sons, Ltd.) 

gymnastic practitioner, and who, according to Mr. Heather Bigg, goes further than attacking matters of treatment, and in order to popularize his own practice endeavours to entwine with it revolutions that shall extend even to the simplest garments. For instance, the gymnastic practitioner maintains that corsets are detrimental to health.

Mr. Heather Bigg's opinions practically are those with which most sensible people would entirely agree. The arguments which he brings forward in favour of them are not, however, very conclusive, as we hope to show. Corsets, he says, are intended in their right and proper use simply to stay and support the body in its natural shape, and not to mould it into funny forms according to the vagaries of fashion. The women of classic times did not use them for this purpose. On the contrary, they had no reason to do so, as their flowing garments did not permit them to display the outlines of their figures; they therefore simply wore corsets because it had been found by centuries of experience that they were conducive to health and serviceable in exertion.

His description of the original corset of Greece and Rome will show to what ancient form of stay the modern corset may be traced. The arrangements of the ancients consisted of three pieces, and these were worn either together or separately, as required. They consisted of supporting bands worn round the body in a way very similar to the "puttees" worn for support round the legs by the present-day soldiery. The main and most useful portion of the corset was a zone, or loin band. Then there was the thoracic band, or strophion, intended to uphold the breasts and conserve the figure. And, lastly, there was the waistband, which filled up the space between the other two. It is from the conjunction of these triple bands that the modern corset has been evolved, as it is worn by women of every class throughout civilized Europe to-day. What was made before in three pieces is now simply manufactured in one. 
Now let us consider the reasons given by Mr. Heather Bigg as to why "women of all dominant and civilized races always wear, and with advantage have worn, some binder or corset"; and again, why the whole history of the world shows that extraneous support is beneficial. In the first place, Mr. Heather Bigg says that in primitive and aboriginal races that practically wear no clothes, the girls may be perfect in form when they arrive at their full growth, but that they are, as a rule, " hideous objects of disfigurement after their first child." The inference is that civilized women retain their beauty in later life owing to the fact that they have worn stays. On the other hand, the fact that the native girls lose their beauty must, according to the argument, be because they have not worn stays; but surely this can be compared with the fading of a flower or its changing colour after fertilization, and is rather due to the absence of any conditions or kind of selection which would tend to preserve the woman's youthfulness. Besides, we need go no farther than our own country to find cases where married women gradually lose their beauty, and the Welsh and Italian women proverbially age rapidly.

The wearing of belts by navvies when they are doing heavy work is possibly a precautionary measure against strain, but it does not refer to the race as a whole, and one would take it that when it is said that Elijah girt his loins in order to run before the chariot of Ahab, it simply means that he fastened up his flowing garments. To the second question as to history showing that extraneous support is beneficial, $\mathrm{Mr}$. Heather Bigg says that the answer is simple even if Darwinian. $\mathrm{He}$ may claim that the "if" saves him, though unintentionally, for in his argument he seems to ignore the main principles of evolution. He says, first of all, that it might just as well be asked why any clothing whatsoever should be found requisite by civilized mankind. He claims rightly, and so far he is in keeping with Darwinism, that man, according 
to his obvious mechanism and morphology, is a creature built on the quadruped pattern. The word is spelt "quadrupled," though presumably this is a printer's error; but he goes on to say that this building was done with the intent that his body should be horizontal instead of vertical. Of course, the body of the original quadruped was horizontal; but in the course of evolution such changes were made as enabled man to occupy an upright position. Mr. Heather Bigg talks as if it was an intentional act on the part of man when he says that he "managed to rear himself in a permanently erect position, and as he has chosen the upright position, so he has to experience some of the penalties attached to it."

The state of affairs is this: man became perfectly well fitted for an upright position, and his internal organs were arranged quite properly for progress on two legs instead of four, although Mr. Heather Bigg claims to the contrary. What may be the case is, that natural selection no longer acts to keep man as perfectly constructed as he was, or to improve him, and some human beings may need support, owing to weakness or the undue development of their bust, just as those of us who suffer from short sight and bad teeth take advantage of eye-glasses and the skill of the dentist. We think it hardly time yet to say that all women need stays, any more than that we all need eye-glasses or should be provided with false teeth at a certain age.

Summing up the matter, when human beings take up work for which their bodies were not specially evolved, or when they wish to do things which at one time all human beings could do, but which, through the cessation of the action of natural selection, they are not now able to do, then they want help. This would explain why our soldiers when marching in South Africa found puttees so useful, as Mr. Heather Bigg maintains.

The case of dress brought forward by Mr. Heather Bigg is exactly a case in point. We have seen in the opening 
chapters of this book that man has lost his hairy covering, and, so far as cold climates are concerned, we must agree with Mr. Heather Bigg that it has been found by experience that clothing is necessary for healthful warmth. All the same, we should like to see some experiments tried to show whether even now it might not be quite possible to exist in this climate with little or no artificial covering. We do not agree at all with the statement that as man " has reared himself from four legs on to two, so he has found by similar experience that some sort of bandaged support is required in order to assist an abdominal mechanism that is inadequate for biped progression."

In order to prove that the gymnastic practitioner is wrong when he says that corsets are injurious to health, Mr. Heather Bigg brings forward the results of experiments made by Professors Roy and Adami, which he says scientifically prove stays to be distinctly beneficial. These experiments were described at the British Association Meeting in I888, under the title of "The Physiological Bearing of Waist-belts and Stays," and the effects of these contrivances were tried not only upon men, but upon animals. It was shown that a gentle compression of the abdomen caused a greater flow of blood to other parts of the body, and conduced in consequence to an increase of mental and muscular activity. The experimenters do not seem to have waited to see whether in the course of time these effects were or were not obtained at the expense of the digestive organs, but they concluded that they had directly explained " the beneficial and extensive use of some form or other of waist-belt by all nations that had passed beyond the stage of absolute barbarity."

The theory has been advanced that stays are derived from swaddling clothes, and that the custom has survived in the case of women alone, for we may neglect the eccasional use of such garments by men in the past at the present time, for, judging from advertisements in the papers, their use is not confined 
to the fair sex. There seems, however, little evidence in support of this theory, and inquiry from a lady who has lived a long time in Palestine has elicited the information that while swaddling clothes are still in use in the Holy Land, stays do not form a part of native dress.

The other part of the body which nowadays appears to be deformed to the greatest extent is the foot. It seems to be considered absolutely necessary, if one is to appear elegant, for one's toes to be pointed in such a way that the apex of the angle is in the middle of the foot instead of on the inner side ; and although the two points are probably unconnected, we might here mention the idea that in a perfect foot the second toe ought to be longer than the great toe. This would make the extreme end of the foot a little nearer the middle line, and in Art the second toe is represented as being the longest in accordance with the Greek canon. These proportions were copied from the Egyptian representations, and the original is probably to be found in the negroes, according to Sir William Flower. The latter points out that the longer our big toe is, the further we are removed from apes; and he found, too, that amongst hundreds of bare and therefore undeformed feet of children in Perthshire, which he examined, he was not able to find one in which the second toe was the longest. These children, would, of course, belong to the lower classes, and it would be interesting to know whether the same things holds good in higher social circles when the foot remains normal. It may be well to remember that Sir William Flower was a surgeon, for Mr. Heather Bigg, who tilts with the gymnastic practitioner once more on the subject of boots and stockings, expresses somewhat different ideas upon the question. $\mathrm{He}$ alludes to the two classes of people in the British Isles who habitually discard boots and stockings-the fisher-folk and factory girls in some of the large Scotch cities. He says that he scarcely likes to be ungallant about the latter, but commends the adult feet of both of these classes to the inspection 
of those who would draft their children into the " bare-footed brigade." He continues as follows: The truth is that the feet of those who have been unbooted till they have reached adult life are splayed and spread, large-jointed, and very generally deformed from all approach to the ideal foot as it is depicted by the greatest painters, or modelled by the greatest sculptors.

We have seen that the ideal foot of the sculptors is probably not a true ideal from an evolutionary point of view, and there is no doubt but that the ideal foot would be the one produced under natural conditions in which we cannot include boots and stockings. We should take it, however, that the stones of the seashore and the floor of a factory are not the ideal surfaces on which to habitually tread.

There is no doubt but that the deformities caused by shoes are often very great, and Sir William Flower sums up the matter in the following sentences:- "The English mother or nurse who thrusts the tender feet of a young child into stiff, unyielding, pointed shoes or boots, often regardless of the essential difference in form of right and left at a time when freedom is especially needed for their proper growth and development, is the exact counterpart of the Chinook Indian woman, applying her bandages and boards to the opposite end of her baby's body, only with considerably less excuse ; for a distorted head apparently less affects health and comfort than cramped and misshapen feet, and was also esteemed of more vital importance to preferment in Chinook society. Anyone who recollects the boots of the late Lord Palmerston will be reminded that a wide expanse of shoe leather is in this country, even during the prevalence of an opposite fashion, quite compatible with the attainment of the highest political and social eminence." 58

After all, it is generally what our eyes are accustomed to that we consider to be right and fitting. The broad-toed shoes that were adopted in the reign of Henry VIII look clumsy 
to us; but so did the pneumatic tyres of bicycles after we had got used to the look of the narrow solid ones. It is not so much the wearing of boots, of course, but the kind of boots that has to be considered.

The high heels of shoes add to the evil effects of the pointed toes, and a copy of a drawing from an advertisement figured by Sir William Flower recalls strongly the stunted foot of a Chinese woman which the wearer of the shoe would be one of the first probably to anathematize. This brings us to the malformation which has been caused through many centuries in a country that can claim a good deal of civilization, and is produced by special bandages after a long and very painful course of treatment.

There is very little evidence of alteration in the form of the head having been practised in this country, though one or two skulls have been found, and there is a tradition that the custom prevailed not very long ago in Norfolk. In France, however, it was well known until recent years, and even yet may not have now become extinct. There are plenty of records in the works of early writers with regard to the practice, and some of the North-American Indians still follow the fashion of their fathers. The Chinook Indians flatten the skull between boards so that they get the name of Flat-heads, and other tribes produce an elongated skull by constructing bandages of deer hide. Deformation of the head seems to have little effect on the free-living American Indians, but the same statement does not hold good among Europeans. According to the reports of French physicians, they have traced all kinds of troubles to the practice.

If we have little evidence of head-deforming in this country by means of compression, we meet occasionally with prehistoric skulls which have been trepanned, and have had inserted into them a small piece of extraneous bone. It is curious that such an operation could have been succesfully made when there were probably no instruments of metal with 
which it could be done, and one might well ask what object could possibly have been in view, especially as the individual so treated had met with no accident that could have rendered the operation necessary. It appears, however, that the piece of bone was probably that of some dead relative, the idea being that the incorporation of it in the head of the young man would give him the qualities of the chief who had departed. It is this notion which probably led to cannibalism. When a brave warrior was slain, his conqueror thought that by eating a small piece of him he might add his adversary's prowess to his own, and when a respected relative died it was thought that his good qualities would pass to those who ate a portion of him.

Besides the alterations that have been permanently made in the shape of the body, there are many curious instances where clothes themselves have been utilized for the purpose of apparently altering its shape. We have seen that Punch's curious figure is due to a costume, while the stuffed breeches adopted in the reign of James I, the great farthingale of Elizabeth's reign, the hooped petticoat of Queen Anne's, and the crinoline of the nineteenth century are instances of fashions that originated with or without apparent reasons.

Just as Mrs. Aria discovered what she terms the ancestress of the straight-fronted specialité corset on a bas-relief of a female figure from one of the mysterious forest cities in South America, so Mr. Rhead has reminded us of the festal dress of Otaheite which Captain Cook figured in his "Geography."

Our grandmothers in their crinoline may have looked like walking hay-cocks; but the young women of Otaheite who carry presents from one person of rank to another look as if they were issuing from an immense drum. It is nothing new to make up deficiencies with padding that is intended to deceive, and while at one time our countrywomen may have made themselves flat-chested with the help of leaden weights, some, judging from articles which we now see displayed in 


\section{EFFECT OF CLOTHES UPON INDIVIDUAL $25 I$}

the shops, are now willing to call to their aid artificial contrivances which give the appearance of plumpness to their bust.

When speaking of padding, one might recall the fact that the most usual place in which it is to be found-in civilian's clothes at least-is on the shoulder. This reminds us of the way in which sleeves were sometimes puffed up above the shoulder. The protuberance thus formed, Dr. Meyer tells us, was originally intended to prevent weapons from slipping off when they were carried over the shoulder. The fashion has since, however, been adopted in civilian costume both by men and by women. 


\section{XXXVI}

\section{FURTHER EFFECTS OF CLOTHES ON THE INDIVIDUAL}

MENTAL EFFECTS OF DIFFERENT CLOTHES-PREFERENCES OF GIRLS FOR CERTAIN ARTICLES OF DRESS-MOVEMENTS THAT DEPEND UPON THE PRESENCE OR ABSENCE OF CLOTHES

PUTTING on one side the special points of detriment which clothes bring about with regard to the body, we may turn to more general effects. Our language is full of proverbial sayings as to the way in which clothes may give beauty, and also as to how much we owe to fine feathers and to our tailors. Quite apart from the results which clothes have upon other people, there are the mental effects which are produced on ourselves. That it is not, perhaps, comfort or discomfort altogether which causes our body to react on the mind, is shown by the results of some investigations made by Dr. Louis W. Flaccus among the schoolgirls of New York. ${ }^{59}$

Feelings of lightheartedness are the result of filmy clothes, and one girl of eighteen said that whenever she had on a garment of this consistency she always wanted to dance. The pleasant mental effects of gauzy stuffs and laces are said by the investigator to be due not only to their lightness, but to the mental associations with which they are connected. Such dresses as those which we have mentioned suggest some gay social function. Again, just as the putting on of a smoking jacket suggests relaxation to a man, so does the assuming of 
evening dress impart the idea that correct behaviour is necessary. Heavy clothes bring about mental depression.

"In a large, heavy hat my spirits are low," says one of the girls who were interrogated, and Dr. Flaccus claims that the mood may change with the hat, while that he has evidence to go upon will be seen from the following answers: "A broad hat makes me feel jolly" ; "If my hat is flat on my forehead, I feel depressed"; "If I have a fancy hat on, I am in a coquettish mood"; or again, "I feel brighter in a hat that rolls away from my face." Then the effect which certain surfaces have upon various persons has to be taken into consideration when dealing with this aspect of the subject, for clothes are made of very different materials. To touch a blanket will set some individuals' teeth on edge, and an irritable mood may result when rough material rubs against the skin. Again, while one person feels chills running down her back when she touches velvet, another will delight to feel a velvety surface. Another remarkable thing which Dr. Flaccus has brought before us is the striking difference between the preferences which girls have for certain articles of clothing.

Most of the girls to whom the questions were addressed put shoes first; gloves came very close, then neckwear, hats, underwear, jewellery, and ribbons ; and though this may not fit in with the ideas of the humorists on the subject, the weakness for hats was shown to be less than one-third that for gloves.

Speaking of the effect that clothes may have upon the action of people, we may recall the way in which skirts and trousers may give rise to different habits. If one drops anything into a boy's lap he instinctively brings his knees together to prevent the object thrown from falling between them; whereas a girl would throw her thighs apart in order to make a receptacle with her frock. Advantage has been taken of this fact by those who wished to discover whether a person with whom they were dealing was a woman, or a man masquerading in female attire. 
More than one novelist has enlarged on this theme, and Mark Twain has used it effectively in the "Adventures of Huckleberry Finn." The occasion is when the hero visits Mrs. Judith Loftus at St. Petersburg, in order to find out what is going on with regard to the murder. Mrs. Loftus, whose suspicions were aroused, got the boy who was dressed up as a girl to thread a needle, to throw a bit of lead at a rat, and having gained some evidence from these two experiments, she tried a third.

She says, "Keep your eye on the rats; you had better have the lead in your lap handy." Huckleberry's story continues: "So she dropped the lump into my lap just at that moment. I clapped my legs together on it, and she went on talking, but only about a minute. Then she took off the hank (he was holding some yarn), and looked me straight in the face, but very pleasant, and said :

"Come, now-what's your real name?"

"Wh-what, mum ?"

"What's your real name? Is it Bill, or Tom, or Bob, or what is it?" 


\section{XXXVII}

\section{THE RISE AND FALL OF FASHIONS}

REASONS WHY FASHIONS ARE FOLLOWED-GAY CLOTHES SEEN WHEN PERIODS OF DEPRESSION ARE OVER-CONDEMNATION OF FASHIONS BY THE CLERGY - QUAKERS-SUMPTUARY LAWS-THE KILLING OF FASHIONS

THE rise and fall of fashions is a matter that affects every nation and practically every individual, for savages are quite as much harassed and tortured by them as any civilized people are. Fashions are perpetuated, as Herbert Spencer has pointed out, by imitation, and from two motives which are widely divergent. It may be prompted by reverence for the one imitated, on the one hand, or by a desire to assert equality with him. In the beginning, no doubt fashions arose with an idea to improve upon nature, though notions as to ideals of beauty must have been hazy in many cases. Nowadays the fact that a particular kind of material is the vogue for dresses or certain feathers the thing for hats may be due to the concerted action of manufacturers and traders who make an opportunity for the sale of the goods in question.

Fashions have been advanced as evidence in support of the proverb that there is nothing new under the sun, and the way in which some of them come round again goes a very long way to prove it in the case of clothes. Luckily some enormities seem to have died out, but in the light of past history we can never feel quite safe, and we never know, on the other hand, 
where some slight change which in itself seems novel may not lead us to ridiculous extremes. Of course, many garments and styles are importations from other countries. The pelisse came from Persia at the time of the Crusaders, just as the kimono was brought in recent times from Japan. Fads and peculiarities and even deformities of Royalty, as we saw in the case of the peruke, have introduced fashions. The crinoline, according to all accounts, was first devised to hide the shame of a princess. Perhaps no other contrivance has brought more nuisance in its train or had more ridicule poured upon it; but it is only one instance of many fashions that have been carried to excess. It is true, as we shall have occasion to mention, that in earlier times laws were enacted to restrict the size of ruffs and the length of the toes of shoes, but often with little effect, and when shape and size did not occupy attention, the costliness of the garment caused restrictions to be made, while the clergy seem never to have ceased from inveighing against the follies of fashions.

In the twelfth century the devil was represented by an old illustrator in the costume of a fine lady with the long hanging sleeves and tightly laced bodice of the time. A hundred years later English preachers took exception to laced openings through which ladies showed their costly under-linen, and dignified them with the name of "gates of hell." In the twentieth century ministers in the United States have wasted their time in scolding the lady members of their congregations for wearing fancy stockings. Sometimes, on the other hand, the clergy themselves have laid themselves open to criticism with regard to the gorgeousness of their apparel.

Periods of depression have been followed by fashions of the gayest. We may recall the times of Charles II, when England breathed again after the civil wars. After the French Revolution, when the reign of terror was over, the Merveilleuses went back to the dresses of antiquity, such as the Athenian costume and that of the Lacedemonian girls, whose tunics 


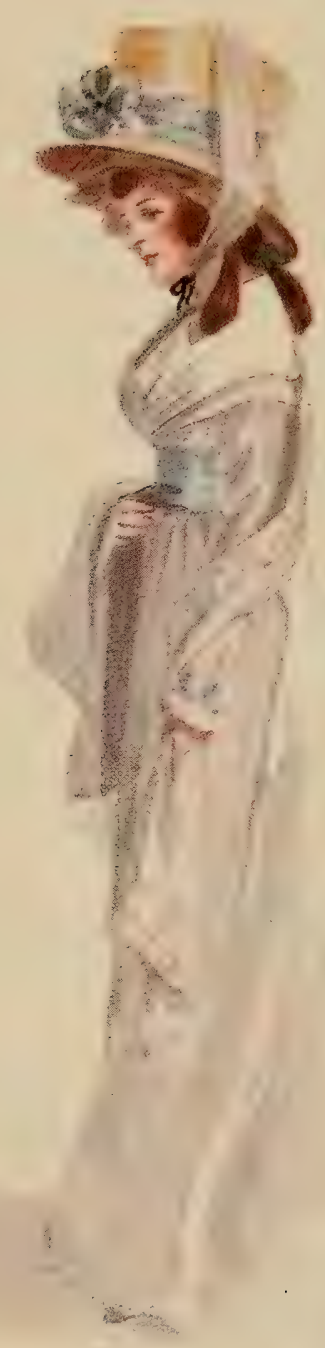

IN THE EIGHTEENTH CENTURY. 

were slit down the sides from the hips. When this was not done the skirts were looped up on the left side above the knee with a cameo brooch. (See Figure I68.) One writer records a wager in which a lady betted that her dress, including trinkets, did not weigh two pounds. She afterwards retired and took

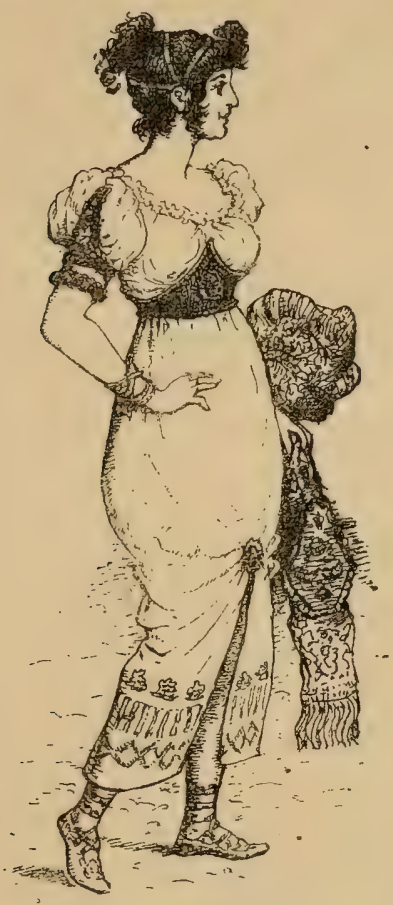

FIgURE I68.-A Merveilleuse (after A. Robida).

off the dress, which was weighed, and the whole costume turned the scales at a little over a pound. One of these dresses went by the name of the "female savage," and consisted of a gauze chemise over pink fleshings, with golden garters. It is not surprising that such costumes, like others before, brought down upon them the condemnation of the Church, and the following " bull," dated at Rome on the I6th October, I80o, is reprinted from The Times of January $28 \mathrm{th}$, I80I :- 
" The Pope, so long engaged in reducing the Gallican Church within the Catholic pale, has not been negligent of the duty of recalling the female form within the petticoat and the handkerchief. After speaking in appropriate terms of the present scarcity of clothing, and of the sensations it may excite even in the withered bosom of a monk, and quoting the authority of St. Clement of Alexandria, His Holiness strictly enjoins his officers, civil and ecclesiastical, to repress, by fine or corporal punishment, according to the circumstances of the case, these crying enormities. He directs, too, that their punishment should be extended to such damsels as though at first sight they appear properly attired, are nevertheless decked in transparent robes, and with a voluptuous and magnificent attire display themselves in very seductive and tempting attitudes. Moreover, fathers, husbands, heads of families, who weakly or negligently permit their wives, daughters, servants, etc., to trespass against these rules, shall not escape with impunity. Also, all taylors, haberdashers, milliners and men-milliners, hairdressers, and others who contribute to these enormities of dress shall in no wise pass unpunished." The bull goes on to state that "all priests, confessors, overseers, churchwardens, and others shall in no wise admit such delinquents to the Holy Supper; that they shall not allow women improperly dressed to enter the church, and if they come they shall be driven out, and if they resist, the higher powers shall be required to lend their aid."

Within the last two or three years even, strictures on women's dress have emanated from the Vatican.

It is said that a Russian nobleman who was used to judge the position of ladies by the amount of furs and clothes that they wore, on seeing an English lady in a costume of the merveilleuse style offered her money in the belief that she was a beggar.

Fashions may have a special significance, as in the case of 
bell-bottom trousers of the costermonger, for it is said that by the cut of these garments the progress of the wearer's courtship can be traced. When he first "walks out," the bottoms of his trousers are of such an ample size that only the toes of his boots can be seen. As matters proceed and the wedding comes into view, the trousers assume more moderate dimensions below the knee, and when at last the man is married he is content with a bell of quite modest proportions, with what a writer in one of our comic papers describes as an almost total absence of "sauciness" in the cut of the garment.

The lengths to which women will go in their desire to appear in the fashion, even if they are not, is shown by the business which a lady in New York is said to have founded. According to all accounts, she deals in nothing but discarded Paris waistbands-that is to say, those which bear the names of wellknown dressmakers. Women in plenty in New York will buy these little strips of silk in order to have them stitched into their own dresses, to give their friends the impression that their garments were made in the French capital.

Laws intended for the good of trade have brought in fashions, as in the case of the statute cap. The very objections made by religious sects such as the Puritans and Quakers, who have departed from extravagance and superfluity, have given rise to new fashions of plainness. Even Quaker ladies must have shown their love of dress, for at a meeting in 1726 the following message was sent by some of the stronger-minded of them to their fellow-women :-

"As first, that immodest fashion of hooped petticoats or the imitation, either by something put into their petticoats to make them set full, or any other imitation whatever, which we take to be but a branch springing from the same corrupt root of pride. And also that none of our ffriends accustom themselves to wear their gowns with superfluous folds behind, but plain and decent, nor go without aprons, nor to wear 
superfluous gathers or plaits in their caps or pinners, nor to wear their heads drest high behind; neither to cut or lay their hair on their foreheads or temples.

"And that ffriends be careful to avoid wearing striped shoes or red and white heeled shoes or clogs or shoes trimmed with gaudy colours.

"And also that no ffriends use that irreverent practice of taking snuff or handing a snuff-box one to the other in meeting.

"Also that ffriends avoid the unnecessary use of fans in meeting, lest it direct the mind from the more inward and spiritual exercises which all ought to be concerned in.

"And also that ffriends do not accustom themselves to go with bare breasts or bare necks."

Perhaps in a minor way superstitions also have tended to keep up fashions. At a wedding, for instance, it is always said that a bride should wear

Something old and something new,

Something borrowed and something blue.

The enactments, however, which were directed against excess in dress do not seem to have always been so successful. The part which the law has played with regard to dress in our own country has been very considerable, and it may be of interest to consider briefly one or two of the so-called sumptuary laws.

In Edward III's reign the people were ordered to dress according to their station, and those who were not of high rank were forbidden to use expensive furs and ornaments. These orders were so neglected that Henry IV revised and strengthened them. Slashed sleeves at the time of Edward IV were prohibited to yeomen and any one below their rank. Legislation was also introduced to lessen the preposterous length to which the toes of shoes had grown, for it was enacted that not even the gentlemen should have them of a greater length than two inches. 
The Records of Chester show the following order made by Henry VIII : "To distinguish the head-dresses of married women from unmarried, no married woman to wear white or other coloured caps; and no woman to wear any hat, unless she rides or goes abroad into the country (except sick or aged persons), on pain of 3s. 4d."

Another law amounted to a tax on persons who dressed elegantly, for those who would not keep a horse and armour ready for the wars were fined heavily if they or their wives wore fine clothes or ornaments. It is probable, too, that Henry VIII's officers took care to collect the fines.

Mary brought in a law against the use of silk, and a little later on the great ruffs claimed attention, for in 1562 it was ordered that no more than a yard and a half of kersey should be used in making a ruff. James I repealed all the sumptuary laws, though we have seen that he and his successors occupied themselves somewhat with the dress of the clergy.

In Scotland, after the rising of I745, an Act was passed forbidding the wearing of tartan as part of Highland dress, under the penalty of six months' imprisonment for the first offence and transportation beyond the seas for seven years for the second. No Highlander could receive the benefit of the Act of Indemnity without first taking the following oath: " I, A.B., do swear, and as I shall answer to God at the great day of judgement, I have not, nor shall have, in my possession, any gun, sword, pistol, or arm whatsoever, and never use tartan, plaid, or any part of the Highland garb; and if I do so, may I be cursed in my undertakings, family, and property, - may I never see my wife and children, father, mother, or relations,-may I be killed in battle as a coward, and lie without Christian burial, in a strange land, far from the graves of my forefathers and kindred; may all this come across me if I break my oath." This severe and harsh Act caused great discontent, and was repealed in I772.

As showing the hindrances caused to trade by some of the 
peculiar regulations, we find that in $\mathrm{I}_{5} 65$ the Recorder of London describes an interview which he had with civic tailors, who were puzzled as to whether they should "line a slop hose, not cut in panes, with a lining of cotton stitched to the slop over and besydes the linen lining straight to the leg." The Recorder, on considering the words of the proclamation which had caused the trouble, gave it as his opinion that they could not; but the tailors, though they went away satisfied, came back to say that their customers had gone to other tailors outside the City, who made their clothes for them in the way that was first suggested. It was this contretemps which caused the Recorder to write to a higher legal authority.

Nowadays clothes and the law have little to do with one another, though occasionally ladies' dresses about which there is a dispute are seriously tried on in court, the legal luminaries meanwhile making a studied pretence of ignorance with regard to the garments. Though there are no statutes to curb modern fashions, yet we are reminded of the rules that have had to be made in certain theatres on account of the overwhelming size of the matinée hat.

Although the law does not seem to have been able to change the fashions to a very great extent, they have sometimes been killed suddenly. In the days of public executions, criminals sometimes elected to wear fashionable garments, and in consequence the demand for them ceased. Sometimes, again, those who were interested in the suppression of the fashion persuaded the doomed man or woman to wear a particular dress, and a judge has been known to compass the same end by ordering the hangman who officiated to deck himself in the objectionable garment.

The wearing of nightgowns in the street by ladies was stopped owing to a woman being executed in her bedgown. The use of yellow starch had its death-blow when the hangman appeared in orange collar and cuffs. Black satin dresses 


\section{THE RISE AND FALL OF FASHIONS 263}

went out of fashion because Mrs. Manning was hanged when wearing one. Now, however, as there are no public executions, there is not this opportunity of getting rid of obnoxious styles, and society ought to look about for another means to repress them. 


\section{XXXVIII}

\section{DRESS REFORM}

CLOTHES TO BE AVOIDED-NEED FOR WARMER GARMENTS - "RATIONAI" DRESS FOR WOMEN

$\mathrm{I}^{\mathrm{T}}$ is evident from what we have said about the effect of 1 clothes upon the body, that there is ample opportunity for improvement in our costume as regards its shape and the methods in which it is worn. We have already said also, when speaking of colour, that, in the case of men at any rate, it might often be more picturesque and brighter. There are several societies whose aim it is to bring about improvements. The Rational Dress League has general objects in view, and it also keeps in mind the special one of introducing bifurcated garments for women. There is also the Healthy and Artistic Dress Union which seems to have general objects.

Education is needed in order that knowledge of the evil results of wrongly shaped shoes and tight stays may be known, and what is more, such training as will enable that strength of mind to be acquired which will prevent the coming generation from being swayed by foolish fashions. The origin of these it is difficult to trace, but the pioneers of them, whether self-centred costumiers or willing victims, ought to be punished in some way. There are points to be borne in mind in connection with garments which have not yet been considered, and they cause otherwise unoffending clothes to do harm. There is no doubt but that the weight of one's dress should 
be suspended from the shoulders, though the great majority of women hang much of their clothes from their waists. A good deal of the weight could easily be taken off this part of the body by the fastening of skirts and under garments to bodices, or by the use of shoulder-straps and the introduction of tunics.

Dr. Cantlie $e^{60}$ has very graphically shown the common

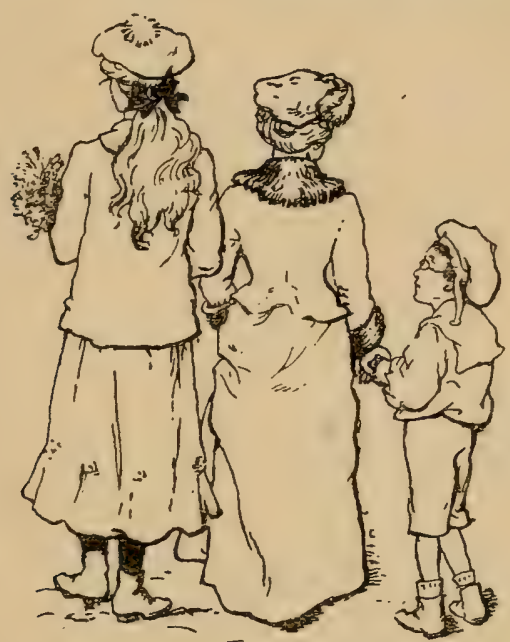

FIGURE I69.-A modern family, consisting of the average-sized mother, the taller daughter, and the puny boy (from a drawing by Miss Audrey Watson in "Physical Efficiency," by Dr. Cantlie, by kind permission of Messrs. Putnam's Sons).

features of a modern family, and he has given a picture (see Figure I69) of a group consisting of the average-sized mother, the taller and larger-framed daughter, and the insufficiently clad boy of poor physique. This author says that the sailor suit worn at the age of two and a half to three years is a recent innovation, and the rather puny young boy of to-day came in with the change. Dr. Cantlie has estimated that, except in very hot weather, children should have a pound of clothing for every stone they weigh, for the one great secret of rendering children healthy is to keep them warm. As a 
matter of fact, a girl that weighs three stone really wears clothes that weigh three pounds; but one of the small boys of the same weight, in a sailor suit, wears clothes that only weigh about half as much as his sister's.

Dr. Cantlie also objects to short jackets which do not cover the loins, and says that the public school that will introduce the Norfolk in the place of the Eton jacket will thrive at the expense of its neighbours.

High collars worn by youths keep the head at the wrong angle, and also perpetuate the deformity of the jaw which is caused by breathing through the mouth. They also prevent the shoulders from being squared in the attempt to get rid of round shoulders. Dr. Cantlie urges a return to the brace worn by our fathers, and still occasionally seen, in which the straps are not united. It is impossible for any one wearing joined braces to stand erect with the shoulders squared, for they press on the neck and cause the wearer to poke his head forward. Dr. Cantlie, however, hopes that the difficulties in the way of obtaining separate braces will not lead to the adoption of the elastic belt, for the only place where this could be worn without bad effects is below the haunch bones, and in ordinary dress this would bring it below the waistcoat. It will be found also that the use of belts by labourers brings evils in its train which were not mentioned by $\mathrm{Mr}$. Heather Bigg, when speaking of the advantages of girding up the loins. (See page 244.)

No account of dress and its developments would be complete without a reference to Mrs. Bloomer and the garments which now bear her name, and are emblematical of rational costume. That women have no absolute claim to petticoats as their own special dress has been made quite clear, and it is equally evident that in many places they wear trousers as a matter of course. Still, in this country there seems to be a rooted objection on the part of the majority to doffing skirts, though this appears, however, to be growing less day by day, in spite 



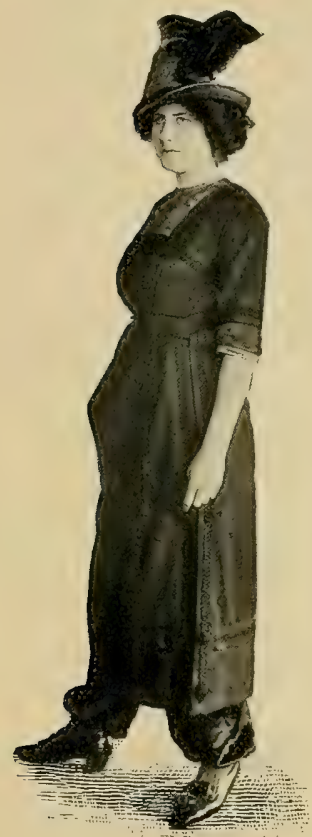

A HAREM SKIRT, WORN OVER TROUSERS, FOR WALKING.

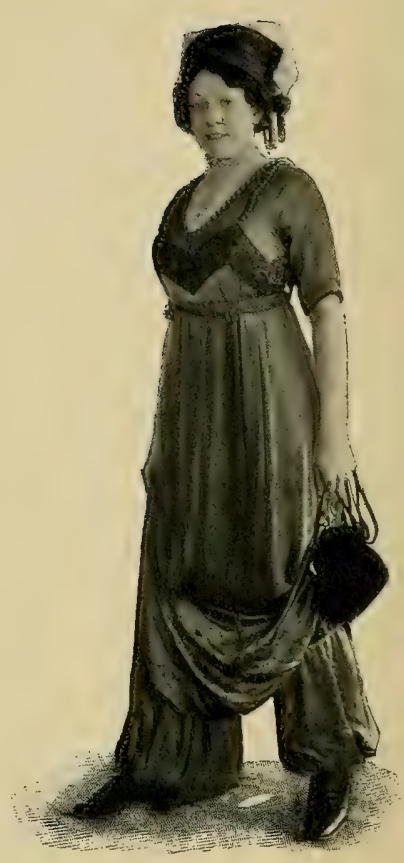

A HAREM SKIRT FOR EVENING DRESS. THE PETTICOAT IS PARTLY DIVIDED.

(See page 267.)

(By the courtesy of the "Country Home.") 
of the many reasons which cause the fair sex to cling to petticoats. As we have found before, garments which fall to the ground give dignity, and women sacrifice their dignity with difficulty. Yet, as need hardly be pointed out, men do not wear dressing-gowns when they are jumping, nor fur-trimmed mantles when they go to business. Dresses with trains could be kept for ceremonial occasions, or when there is nothing much to be done, or again, we might add, when there is little dust to be raised. The "harem skirt," of which we give illustrations on Plate XII, was a compromise which was brought out recently, but it met with ridicule, and therefore had little chance of becoming generally adopted. In one form the bottom of the skirt. was divided into two, while in another actual trousers were worn beneath it.

Bacteriology has shown us that the long skirt disseminates germs as it trails along the ground; in fact, it stirs them up for other people to breathe, and the culprit herself carries off as her fair share a large quantity which settles on her dress. In this way the germs of disease are carried home to the dwelling-house.

In these days also, when women even jump on and off motor omnibuses before they are at a standstill, it is evident that long frocks are objectionable and dangerous, and quite short ones have happily been fashionable for some time. Their advantages other than hygienic ones have, however, been lost, in some cases owing to their tightness, which has been ludicrous in the extreme, and given them the name of " hobble skirts." At the same time, the writer has never seen any fashion which, when not carried to extremes, has struck him as being more effective and becoming.

When lady gardeners were first employed at Kew Gardens, it was found that their skirts got in the way, and were liable to damage the plants. The Director ordered that the girls should wear a suitable costume, and they adopted divided garments, though it must be said that they covered them to 
some extent with an apron. In riding-dress of course ladies wear trousers under their habits when they use a side saddle, although it has been considered right of recent years in this country for them to ride astride, as do the ladies in Mexico and other parts of America.

Chaucer described "The Wife of Bath" as wearing "on her feet a paire of spurries sharpe." From this we may judge that she also adopted a cross saddle, and as a matter of fact in the Elesmere MSS. we find a picture of her, showing that she rode astride, and was dressed in a curious garment like a divided bag. As a matter of fact, in olden times the women of the lower orders always rode astride, as did ladies when they were in a hurry or went hunting, though otherwise from Anglo-Saxon times downwards the side saddle was used by the quality.

On the Continent, ladies who go shooting very often dress like their husbands, and a year or two ago the American newspapers were full of accounts of a lady who imitated the riding costume of a hunting man to the smallest detail. Apropos of this, The Field ${ }^{61}$ told an amusing story of an English lady who in a measure unintentionally forestalled our American cousins, for after she had had the best part of her habit carried away by some aggressive brambles, she was seen scudding after her horse in a pair of real top boots.

Divided garments only appear unfeminine because we are unaccustomed to see them on ladies, and it is no secret that they are worn to a very great extent under skirts. Doubtless there may be some to whom the very idea of such a thing is abhorrent, and possibly there are still wardrobes like those of a good lady mentioned by Miss Alice Morse Earle ${ }^{62}$ in her book on the "Costume of Colonial Times." She was the wife of a respectable and well-to-do Dutch settler in the New Netherlands, and her name was Vrouentje Ides Stoffelsen, and she left behind her in I64I, " a gold hoop ring, a silver medal and chain, and a silver undergirdle to hang keys on; 
a damask furred jacket, two black camlet jackets, two doublets, one iron gray, the other black; a blue, a steel-gray lined petticoat, and a black coarse camlet-lined petticoat; two black skirts, a new bodice, two white waistcoats, one of Harlem stuff; a little black vest with two sleeves, a pair of damask sleeves, a reddish mourning gown, not linen ; four pair pattens, one of Spanish leather; a purple apron and four blue aprons, nineteen cambric caps and four linen ones; a fur cap trimmed with beaver; nine linen handkerchiefs trimmed with lace, two pair of old stockings, and three shifts. One disposed to be critical might note the somewhat scanty proportion of underclothing in this wardrobe, and as Ides's husband swore 'by his manly troth' that the list of her possessions was a true and complete one, we are forced to believe that it was indeed all the underclothing she possessed."

It seems, however, as we have said before, that the actual ugliness of many of the so-called bloomer costumes which were in vogue a few years ago, did much to keep back progress in the direction of their adoption. It seems as if women were frightened, as it were, to go the whole hog, and instead of wearing neat knickerbockers they had them exceedingly baggy and inelegant, or adopted a kind of hybrid costume, half bloomers and half skirt.

Let us see what the tendency now is with regard to a rational dress for women. Mrs. Bloomer had a skirt just below the knees, and trousers gathered in at the ankles. The modern bloomers come only to the knee, but really, as Dr. Bernard O'Connor says when writing in the Gazette published by the Rational Dress League, ${ }^{63}$ " they are made too full." Dr. O'Connor recommends for active exercise, such as cycling, something like a sailor's jacket and sailor's trousers, but the latter should end and be gathered in at the knees. In addition there should be long tight stockings, and Dr. O'Connor adds that tights throughout would be preferable to the ordinary bloomers. 
It would seem, however, that this dress for general use might be improved as regards both form and elegance, and that a long coat or tunic, reaching nearly to the knees, with fairly tight knickerbockers, is the rational dress that is most to be commended for women. 


\section{BIBLIOGRAPHY}

The small numbers given in the text correspond with those printed here.

พro.

I. "The Origin of Species," by Charles Darwin. (First edition published 1859) • • • • • • • 2

2. "Development in Dress," by George H. Darwin. Macmillan's Magazine, September, 1872, page 410 • • •

3. "Pithecanthropus erectus, eine Menschenaehnliche Uebergangsform aus Java," by Eug. Dubois, Batavia, 1894 . . 5

4. "Journal during the voyage of H.M.S. Beagle," by Charles Darwin. Minerva Library, I889, page I54 • $54 \quad$ • 99

5. "The Industrial Arts of Denmark," by J. J. A. Worsaae. I882,

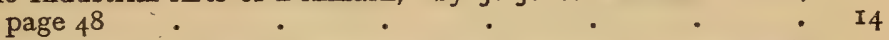

6. "Development in Dress," by George H. Darwin. Macmillan's Magazine, September, I872, page 4I2 . .

7. Notice of Lecture given by Mr. Allan Poe Newcombe, in the Sandwich Islands. Quoted from the Honolulu Commercial Advertiser in The English Mechanic, No. I934 . .

8. "Development in Dress," by George H. Darwin. Macmillan's Magazine, September, I872, page 4I2 • • •

9. "The Human Beast of Burden," by Otis T. Mason. Smithsonian Report of the United States National Museum, I887, page 24679

Io. " Anthropology," by Edward B. Tylor. I892, page 236 . • 8I

II. "The British Lake Dwellings near Glastonbury." I896, page I3 86

I2. "The Gem Cutter's Craft," by Leopold Claremont : 90

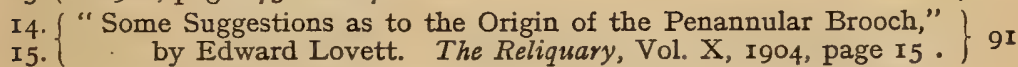

I6. "Races of Man," by Oscar Peschel. English Translation, I889, page I74 • • • • • • •

I7. "The Cyclopædia of the British Costumes, from the Metropolitan Repository of Fashions." I826, page I96 . . I05

I8. A letter in The Morning Post of November 12th, I897, from Messrs. André \& Co. .

I9. "English Costume," painted and described by Dion Clayton Calthrop. I906, page I30 • . . . II4

20. Article on "Cockades "in The Sketch for March 9th, I898 . . II6 
No.

PAGE

2I. "English Costume," painted and described by Dion Clayton Calthrop. I906, page I30 • . • • • II6

22. "Costume from Monumental Brasses," by Herbert Druitt. Igo6 I2I

23. "Rational Dress v. Industrialism," The Rational Dress Gazette, No. 88 , by Dr. Alice Vickery, page $35^{6}$

24. "Shoe-throwing at Weddings," by James E. Crombie, Folk Lore, Vol. VI (1895), page 258 . . . . I30

25. "Ecclesiastical Vestments, their Development and History," by R. A. S. Macalister. I896, page r40 . • . 138

26. "Vestiarium Christianium : the Origin and Gradual Development of the Dress of the Holy Ministry in the Church," by the Rev. Wharton D. Marriott. I86I, page 48 . I40

27. "Ecclesiastical Vestments, their Development and History," by R. A. S. Macalister. I896, page 2I . . I40

28. A letter in The Guardian, by G. C. Coulton, August, 1907 • . I45

29. Paedag. Lib. iii., page 300 . • . . I53

3०. "Costume from Monumental Brasses," by Herbert Druitt.

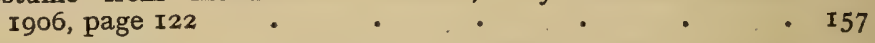

3I. "College Caps and Doctors' Hats," by Professor E. C. Clark. Archaological Journal, Vol. LXI. I894, page 36 .

32. "Costume from Monumental Brasses," by Herbert Druitt. I I 906

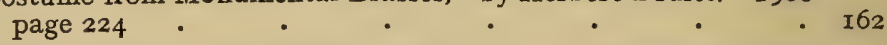

33 "The Sacring of the English Kings," by J. Wickham Legg. Archcological Journal, Vol. XLI. 1894, page 35 • • I65

34. "History of the King's Body Guard of the Yeomen of the Guard," by Colonel Sir Reginald Hennell. I904, plate facing page 32

"Uniforms of our Fighting Forces, Regimental Survivals and 35. "Uniforms of our Fingrities," by R. Caton Woodville. Cassell's Magazine, 36. $\left\{\begin{array}{l}\text { I906, page } 524 \text {; and "Peculiarities of British Army Dress," } \\ \text { by Walter Wood. Pall Mall Magazine, Vol. XI. 1897, I76 } \\ \text { page } 527 \text {. }\end{array}\right.$

37. "Yester Year," by A. Robida, English translation, page 83 .

38. A lecture given by Mr. George Heppel before the Hammersmith Literary and Scientific Society

39. " Naples in I888," by Eustace Neville Rolffe • • I89

40. "Notes by a Naturalist on H.M.S. Challenger," by Professor Moseley . • • • •

41. "Notes by a Naturalist on H.M.S. Challenger," by Professor Moseley, page 423 • $\cdot{ }^{\circ} \cdot{ }^{\circ}$

42. "Costume in England," by F. W. Fairholt. Revised Edition, I885, Vol. II, page 303 .ं " by Helen C. Gordon. The

43. "The Whole Stock of a Coquette," by Helen C. Gordon. The English Illustrated Magazine, February, I90I, page 45I • 207

44. "Costume: Fanciful, Historical, and Theatrical," by Mrs. Aria. I906, page I99

45. "Curiosities of Literature," by Disraeli. Vol. I, page I86 .

6. "English Costume," painted and described by Dion Clayton Calthrop. 1906, page 20

202

203

206 
47. "Costume in England." by F. W. Fairholt. Revised Edition,

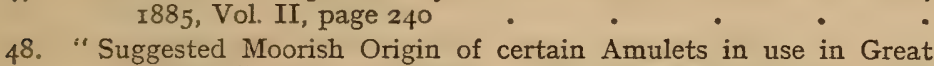

PAGE Britain," by Dr. Plowright. The Reliquary, Vol. XII, I906, page 106

$2 I 6$

49. "Horse Brasses," by Lina Eckenstein. The Reliquary, Vol. XII, I906, page 25I • . . . . 2I9

50. "Animal Artisans," by C. J. Cornish, 1906, page 25I . . 224

5I. Article by Sir James Yoxall in The Journal of Gipsy Lore, new series, Vol. I, part I, I907 . • . . . 228

52. Article by J. Chevasse. Evening News, April 5th, I907 • - 235

53. Article in The Daily Mail, September 4th, 1907 . . 236

54. "Essays on Museums and other subjects connected with Natural History," by Sir William Flower. 1898, page 350 • . 240

55. "Yester Year," by A. Robida, English translation, page 9r 24I

56. "The History of the Corset," by Geraldine Vane and F. Glen Walker. Lady's Realm Summer Number, I90I • . 242

57. "Spinal Curvatures," by Heather Bigg. I905 . . . 242

58. "Essays on Museums and other subjects connected with Natural History," by Sir William Flower. I898, page 347 • . 248

59. Article in The Morning Leader of April r7th, 1906 . - . 252

6o. "Physical Efficiency," by James Cantlie. I906 . • . 265

6I. Leaderette in The Field, August 29th, 1902, page 452 • . 268

62. "Costume of Colonial Times," by Alice Morse Earle, page 28268

63. "Why Won't They Alter It?" by Bernard O'Connor, Rational Dress Gazetle, No. 87, page 352 • . . . 269 



\section{INDEX}

Note-The numbers in heavy type refer to the pages on which figures will be found.

ABbesses, costume of, I 47

Abergavenny, the Marquis of, wears badges, 66

Academical dress, 156

- hoods, I48, I 57

Achievements, styles of, 63

Acrobat, dress of, $2 I_{3}$

- tights of, 2I3

- trunk hose of, 2 r3

Admiral, uniform of, worn by coxswains at Eton on the Fourth of June, I25

Africa, the West Coast of, little clothing worn on, 7

Aggries, 82

Agilbert, Bishop of Paris, ring of, 83

Aiglets, 73

Aiguillettes, 73, 104

- Mr. Caton Woodville on, 177

- of aides-de-camp, 177

- - footmen, I03, 104, I 78

- Household Cavalry, I 78

- a Knight of the Bath, I7I

- - Knight of St. Michael and St. George, I 7 I

Ailette, 62

Albe, I $47, I 48$

- of James II., 165

- originally a secular garment, I4I

- replaced by surplice, I3 8

Alhambra, 218

Almshouses, costumes of, 125

Almuce, I 47, I 48

- forerunner of the tippet, 158

Ambassadors, cockade of Danish, II 7

- - English, II7

- - Foreign, II7

- - French, II7

American, dress of the, 236

Amethyst, supposed powers of the, 90
Amice, I48, I65

Amulet, arrow-head, 22 I

Amulets buried with the dead of ancient Egyptians, 89

- crescent-shaped, 218

- heart-shaped, 220

- worn by Egyptian children, 89

Andaman Islanders, painting the body among, 205

André, Messrs., \& Co., on cockades, I I I

Anglo-Saxon, bandaged stocking of, 49,50

Animal actors, clothes of, 224

Animals, colour of, in connection with ceremonials, 226

- curious variations of, produced under domestication, 225

- mutilation of, 225

- spotted when young (see Frontispiece) 68

Anklets, 7

Anne, apron of Queen, Iog

- Consort of James I, glove of, 7I, 71

Antiquities, Museum of, Copenhagen, I3I

Apparel of chasuble called an orphrey, I 46

- on albe, possibly remains of clavi, I44

Appendix, vermiform, 2

Apron, 108

- of barge-woman, milk-woman, and hospital nurse, I09, IIo

_ - bishop, a vestige of the cassock, I 49

- - housemaid, I08

- - Judy, 195,

- - masons, 172

- nuns, I5I

- Queen Anne, Iog 
Aprons, tiger skin, of Leicestershire Regiment, 184

Arab women, 89

- - ideas of modesty, I54

Arabs use folds of robes as pockets, 79

Archers, Scottish, coats of, I68

Aria, Mrs., on the ancestress of the straight-fronted specialite corset, 250

- - on the unwritten laws that rule the wearing of a mask, 208

Armlets conferred on soldiers, 83

- need for cooling, in some climates, 83

Armorial bearings on ladies' dresses, 61, 62

Armour, 60

-a development of dress, 9

- of chargers, 218

Arms, coat of, 60

- of England, 63

- - schools and colleges, 65

- Thomas à Becket, 147

Arran murder case, I3I

Arrow-head amulets, $22 x$

Arrow-heads, flint, as pendants, 90

Arts, gown of master of, $\mathbf{I}_{57}$

- hood of bachelor of, I58

Ashdown, Mrs. Charles, on children's clothes, I20

Atella, celebrated for Italian farces, I89

Athletic clubs, parti-coloured dress of, 233

Aurelian, distribution of oraria by, I 43

Austria, Emperor of, I8I

Austrian, dress of the, 236

Axe for killing wounded horses, I79

Ayahs, nose-rings of, 8I

BABYLON, finger-rings in, 83

Baby's glove without fingers, 68,69

Bachelor of Arts, hood of, $15^{8}$

Badge and crest, difference between, 65

- broad arrow, 66

- of Black Prince, 65

- - Edward III, 67

- - the porters of the Inner Temple, 66

Badges, hereditary, 65

- regimental, I79, I8I

- signs derived from royal, 66

- of Gloucestershire regiment, I8I

-
Badges of the Yeomen of the Guard, I67, 167

- Watermen, 66

- worn by the Marquis of Abergavenny, 66

Bag-wig, vestige of the, 97, 97, ro3, 106, I69, 170

Baildon, Mr. Paley, on new garments put over old, Io8

- - - the coif, I62

Baldric, 77

- modern use of, 77

- ornamented with bells, 77,79

Ballrooms, bare necks in, II

Band, black on arm as mourning, r35

- chin, I50, 151

- hat, 37,39

Bandaged stockings of Anglo-Saxons, 49

Bandages, leg, 49, 50

Bandbox, 33, 34:

Bandoleer, on baldric, 77

Bands, 32, 32

— of barristers, 32

- - blue-coat boys, 32, 33

- choristers at Jesus College, Cambridge, 32, 33

- J Jan Steen, 32, 34

- John Pym, 33, 34

- - Milton, 33

- - small boys, 33,35

- - the legal profession, $I 6_{4}$

- Winchester scholars, I24

- on a lady's nightgown, 215, 215

- worn with a black Geneva gown, 32,138

Bantams, booted, 226

- frizzled, 225

Baptism, vestments used at, I20

Barbarians wore trousers, 56, 57

Barge women, apron of, Iog; Plate VIII facing page Iro

- - costume of, I09

- - sun-bonnet of 45 ; Plate VIII. facing page IIO

Barme-cloth (apron), Iog

Barons of the Exchequer, robes of, $-\mathrm{I} 63$

Barristers' bands, 32

- gown, 163, I64

- wigs, 96

Basquine, 24I

Baton of-drum-major, I 79

- Field-Marshal, I66

Beadle, dress of, I07,

- in Punch and Judy, 107, I94, 196

Beads as currencies, 82 
Beads, blue popo, worth their weight in gold, 82

- early used in England, 82

- from Egypt, 82

- of the prehistoric Egyptians, 82

- still fashionable, 82

Beagle, H.M.S., voyage of, 8

Beard of Edward II, 95

- - III, 95

Beards, closely shaved by Normans, 94

_ - in Edward IV's time, 95

- cut by Romans, 94

- parted or trimmed by Saxons, 94

Bedford, Duchess of, riding habit of, I 86

Bedgown, woman executed in a, 216

Beefeaters, cap of, I23

Bells as ornaments, derived from flowers, 233

Belt of groom, I02, 103

_ - origin of, IO2

Belts, Dr. Cantlie on the use of, 266

- worn by navvies, 244

Bernard, on blowing the nose on the chasuble, I 45

Bhurtpore, battle of, I 8 r

Bib, Iog

-of infant, 123

Bibliography, 271-273

Bigg, Mr. Heather, on the erect position of man, 244,245

- - - - rapid loss of beauty in native girls, 244

- use of stays, 242, 243

Billet, sign of the Crooked, ro6

Binder of infant, $\mathrm{I} 20$

Biretta, evolution of, $x 60$

Bishop, hat of, 159, r6o

- method of buttoning trousers, 187

- rochet, chimere, and lawn sleeves of, $\mathrm{I}_{4} 8$

Black as mourning, I34

Bloomer, Mrs., 59, 266

- - dress of, 269

Bloomers, Dr. Bernard O'Connor on, 269

Blouse, blue, of the butcher, 229, 237

Blue coat boys, 123

- - bands of, 32, 33

- favours, 229

Boadicea, dress of, $23 \mathrm{I}$

Boar, wild, spotted when young, 68

Body, clothes used to alter the shape of, $25^{\circ}$

Bohemians, the King of the, wore no ostrich feathers, 66
Boiler cleaners, combination garments of, 237

Bone inserted into prehistoric skulls, 249

- pin, 76

Boots, jack, I 74

- of bridegrooms removed by brides in Russia, $\mathrm{I}_{3} \mathrm{I}$

- ornamentation of modern, 46,47

- top, 48,49

- - upper parts now immovable, 48,49

Borough Councillors, robes of, Ior

Bouquets carried by coxswains on the Fourth of June at Eton, I25

Bows inside ladies' hats, $4 \mathrm{I}, 43$

- of silk ribbon inside hat, 40, 42

Boy catching an object in his lap, 253

Boys, blue-coat, I23

- colour preferences of, 228

- dressed as soldiers, II9

- petticoats of, I2I

Brace in which the straps are not united, 266

Bracelets, 7

- need to be cooled in hot climates, 83

Brandenburg, Albrect von, with two palls, I47

Brandon, John, brass to, 26

Brasses, 26, 62, 62, I73, 174; ; Plate IV, facing page 26

- chrysome, I2I

Brats, 224

Breast cloth of nun, I5O, 150

- plate of horse, amulets on, 2 I9

Breasts, bare, in Ancient Egypt, 54, 55

- - in Korea, 54, 56

- - in the time of James I, 55

Breeches, knee, 57

- of Lord Darnley, 2r3

- origin of the word, $23 \mathrm{I}$

- petticoat, of sailors, 187

- plush, I03, 104

- stuffed, 250

- Venetian, of pantaloon, 212, 212

Bridesmaids, origin of presents made to, by bridegroom, I 29

Bristol, Red Maid School of, I24

Broad arrow badge, 66

Bronze Age chieftains, dress of, $\mathrm{I}_{4}$, $15,54,54$

- - people wore deerskin cloaks retaining horns, 86

Brooch, 89

- safety-pin like an Etruscan, 74, 75

- the buckle a, without hasp, 9I

Brooches, pin ring, 9I 
Brooches to fasten tunic, I3, 13

Buckle, 9 I

Bulgaria, shoe money in, I30

Burden, primitive method of carrying a, 76,78

Busbies, caricatures of, 183

Busby, 177

- development of, 42

- of Rifle Brigade, I79

- origin of the, Sir George Darwin on, $4 \mathrm{I}, 44$

- red flap on, 42, 44.

Buskins, I 45

Bust, padding used to improve the, 25I

Butcher's blue blouse, 237

Butterman, white clothes of, 237

Button, 86

- covered with crape, 180

- Mr. P. W. Reynolds on the survival of $a, I 84$

Buttonholes, exaggerated on uniforms, 28,44

- knotched, 106

- laced, I06

- on the backs of coats, 20,20 , 2 I, 21

Buttons, 18,183

- antiquity of, 88

- as chronicles, I9

- done up differently by men and women, I 5,17

- horizontal row of, on sleeve, 25, 27

- meaningless, on ladies' dresses, 87

- numerous, on sleeve of undervest, 26 ; Plate IV, facing page 26

- of brass on Dutch skeleton dress, I05, 107

- Legion of Honour, Ir6

- man's coat on right side, $\mathbf{I}_{5}, 16$

— - page boys, I05, 107

- woman's coat on left side, I 5, 16

- on coats of Grenadier Guards, 2 I

_ - cuffs, 25, 26, 27, 28

- overcoats of Commissionaires, 23

- - postilion's jackets, 27

- - sleeves of clergy, 25

- the back of coats, 19, 20, 21, $22,23,24,25$

- - the back of tramway driver's coats, 22,23

- problematical, I2

- replaced by knobs in the East, I5

- vertical row on sleeve, $25,26,26$, 28
Calthrop, Mr., on survivals of the chaperon, I I 5

- - - the costume of Harlequin, 2 I I

- - - evolution of the cockade, II 4

- $\frac{1}{16}-$ origin of the cockade,

Camels, cowry shells on the trappings of, 22I, 223

Cameron Erracht tartan, I79

- tartan, 179

Canaries, yellow, 226

Cane of drill sergeant, 179

Canes, be-ribboned, $9 I$

- tasselled, 9I

Cannibalism, probable origin of, 250

Canterbury Cathedral, shield, helmet, and surcoat of Black Prince in, 63, 63, 64

Cantlie, Dr., on short jackets, 266

- - the effect of insufficient clothing, 265, 265

_ _ _ - use of belts, 266

Cap, college, 33, 124, I59, 159

- Hungarian, I77

- judge's sentence, 162

- line of Lancers, I 78

- livery, Io6

- of Beefeaters, I23

- - dignity, ecclesiastical, I60

- - housemaid, 108

- Hungarian peasant, 42, 44

- nuns, I5o, 150, I5I

- - the Lancers, a Polish headdress, 177

- Scotch, streamers of, 39, 40

- statute, I23, 259

- Tudor flat, 160

Cape, combined with hood, I I 4,114

Caps not to be worn by married women, $26 I$

Cards, playing, show Tudor dresses, I72

Carolines, haircombs of West, 86

Cases of brass for waiters' buttons, IO4

Cassock, $\mathbf{x}_{49}$

- of Benedictines, 147

- once generally worn, 138

Casula, forerunner of the chasuble, I 43

Cater cap, I 59

Cattle, hornless, 226

Cavalryman, modern, compared with Cromwell's Ironsides, I 75, 176 
Cave men, drawings of, $7,7,8$

- painting of the body by, 200

- wore ornaments but no clothing, 6

Ceremony, primitive dress worn on occasions of, 4,99

Chain mail, $\mathrm{r}_{73}, \mathrm{I}_{74}, 174$

Chains for the neck in Richard II's time, 82

- of Mayors, origin of, 83

Chancellor of a University, robes of a, I57

Chapel keeper at Wellington Barracks, top hat of, $\mathrm{I} 83$

Chaperon, III

- development of, II4, 114, 115

- of Richard II's time, I I4

- survival of, I70

- vestige on gowns of City Livery Companies, I72

- - mantles of knights, II5

Chaplet of flowers used after baptism, I 2I

Charles I regulates clerical costume, $\mathrm{I}_{3} 8$

- II, formation of Guards by, I82

Chasuble, $\mathrm{r}_{44}, 144$

- casula, the forerunner of, I43

Chauffeurs' cockades, II 7

Checks, 23I

Chemise, 214

- gauze, of Merveilleuses, 257

Chevasse, Mr., on individuality shown by clothes, 235

Children carried on the left arm, I7

- dressed like their parents, II9

- sucking the left breast, I8

Chimere, $\mathrm{I}_{4} 8$

Chimpanzee, hair of, 5

China, painted pasteboard figures burnt at funerals in, 203

- puppet-show in, I9I

- the use of paint by women in, 204

Chin band, I 50,151

Chinese women, stunted foot of, 249

Chinook Indians, deforming the heads of children, 248

Chiton, I39

Choker, I 49

Choristers at Jesus College, Cambridge, bands of, 32,33

Chrism cloth, 120

Christians, dress of ancient, I39

- early, wore the same costume at worship as at home, I4I

Christ's Hospital, I 23
Chrysalis, I 20

Chrysolite as, a detector of poison, 90

Chrysome, 120

- brasses, I2I

Chulos in bull fight, red rag of, 228

Churches, Gothic, compared with hennin-like head-dress, 37,38

Clans, tartans of Scotch, 232

- with several tartans, 232

Claremont, Mr., on opals and bad luck, 90

Clark, Professor E. C., on college caps, 160

Clavi, I42

Clement, St., on special dress for worship, I 53

Clergy, adoption of vestments by English High Church, I43

- black habit of, 229

- buttons on sleeves of, 25

- condemnation of dress by, 256

- criticized for gorgeous apparel, 256

- in Holland, dresses of, ${ }^{4} 8$

- wear academical hood over surplice, 148,158

Cloaks, deer skin, of Bronze Age people, retaining horns, 86

Clock, 50, 51

- origin of, 50

Clocks of clowns, 200

Cloth, breast, I5o, 150

- chrism, I20

- pied, 232

- parti-coloured, 232

Clothes adopted for æsthetic reasons, IO

- - reasons of coquetry, II

- adoption of, for ornamentation, 6

- - - reasons of modesty, 6

- - - warmth, 6

- dispensed with on ceremonial occasions, roo

- distortions caused by, 239

- effect upon action, 253

- - of, upon the outsider, 234

- everyday, worn at night, 2I 4

- first worn by women, 9

- made from the bark of trees, 9

- mental effect of, 252

- minimum of, worn at sports, 5

- not necessarily worn in cold climates, 8

- - worn at night, $2 \mathrm{I}_{4}$

- of animal actors, 224

- - dolls, roo 
Clothes of monkeys, 224

- - Punch, origin of, I90

- represented among animals, 217

- Sunday, 153

- swaddling, 120

- the principles of evolution applied to, I

- used to alter the shape of the body, 250

- useful characters always retained, I2

- why worn, 6

- worn at executions, become unfashionable, 262

(See also under the headings of Costume and Dress)

Clothing, not worn by cave men, 7

- preferences of girls for different articles of, 253

Clown, 2 II

- clocks of, 200

Clowns, painting of, likened to that once in vogue in China and Japan, 205

- paint of face of, 200

Clubbed hair, 98

Coachman, coat of, I03, 105

- Lord Mayor's, wig-bag of, I03, 106

- origin of dress, $\mathrm{IO} 2$

- red coat of royal, I74

— wig of, 96, 103, 105

Coastguard, revers of, buttoned back, 29

Coat, blue in sixteenth century, I23

- - ot police, I23

- buff, I74

- development of the modern, I2

- evolved from the shawl, I3

- lapels, nicks in, 30, 31,

- patched, of harlequin, 2 II

- pouter, I03, 104

- red, a best, I74

- - origin of, 184

- - survived for a long time in Cornwall, I74

- skirts buttoned back for riding, 25

- swallow-tail, evolution of, 24,25

Coats at Harrow, 124

- Westminster, I24

- of arms, 60

- Scottish Archers, I68

Coats, waterproof, of, lambs, 224

Cobbett, criticisms on Quakers, 87

Cock of a hat, 44

Cockade, 44, 45, III, 111

- black, I I I
Cockade, bow of ribbon on, II 3

- evolution of, III, II2, II4

- for mourning, II2, 112, II6

- jagged edges of, II 5

- material of, II2

- of ambassadors, II 7

- Chelsea pensioners, II3, 113

- various colours, II 5

- regent, 113, II4, II6

- royal, II2, 113, II6

- treble, 111, II3

Cockades, not under the jurisdiction of Heralds' College or Lord Chamberlain, II 2

- of foreign ambassadors, $\mathrm{II}_{7}$

- - chauffeurs, II7

- those entitled to use, III, II 6

- worn by gentlemen, III

Cocking, I 49

Coffins, Bronze Age, I4

Coif of Serjeant-at-law, I62

- Order of the, 162

- vestige of, I6I, 162

Coin, custom of breaking, upon engagement, 84

Coldstream Regiment, motto of, 182

Collar at Eton, 33

- broad lace, at Eton, I24

- silver worn by additional drummer I 80

Collars, high, keep the head at a wrong angle, 266

- metal, of Padaung women, 83 Plate VI, facing page 83

- of Court ushers and vergers, I63

- - ladies' mantles standing up, 34

- - nuns, $1_{50}$

- worn by pet animals, 222

Colobium sindonis, 165

Colonial, dress of the, 237

Colour, craving for, shown by the gorgeous dress of Masons, 229

- - - green scarfs of the Foresters, 229

- - - - pageants, 227

- of academical dress, 230

"Colours," I43

- gay uniforms come under the category of courtship, 185

- heraldic, derived from flags, still worn, 229

Colours, house, 125

Colours of ancient drawings due to caprice of artists, 96

- Naval uniform, I86

- - regiments, 230

Columbine, ballet dress of, 212 
Comb as an ornament, 85,86

Combs, hair, 85,86

- loom, the origin of the ornamental comb, 85, 86

Combination garments of boiler cleaners, 237

- - Normans, 237

Coombe Hill School, King's Langley Priory, dress worn by girls at, 126, I 27

Commissionaires, buttons on overcoats of, 23

Companies; Livery, robes of, Ior

Complexions, false, of Roman ladies, 206

Convicts' dress, 66

Cope, $147, I_{4} 8$

- of fifteenth century, I 59

Cornish, Mr. C. J., on animals' clothes, 224

Corps piqué, Montaigne and Ambrose Paré on the suffering caused by the, 24 I

Corroboree, paint used at a, 202

Corset, misspelling of the word, $24^{\circ}$

- of Greece, 243

- - Rome, 243

Corsets, crusade against, 24I

Cosmetics used by Roman ladies, 206

Costermongers, dress of, 237

- trousers of, show progress of wearer's courtship, 259

Costume, clerical, regulated by Charles I, I38

- connected with religion, I37

- ecclesiastical, similar to civil in early times, I39, 140

- of barge-women, 80

- - the clown, Elizabethan, 200, 201

- dolls, 198

- - milk-women, 80

- nuns and abbesses resembled that of widows, $I+7$

- - servants', derived from that of masters, 102

- indicating the profession of the wearer, 234

Costumes adopted in girls' schools, I26

- of hospitals for pensioners, I25

- ugliness of bloomers, 59, 269

(See also under the headings of Clothes and Dress)

Coulton, Mr. G. C., on the evolution of the maniple from a pocket-handkerchief, $\mathrm{x} 45$

Courier bags carried on a baldric, 77 , 78
Court dress, mistakes made in, I69

- ushers, collars of, 163

Coventry, Lady, death due to painting the face, 207

Cowboy's long hair, 92

Cows, clothing of, 224

- rainproof jackets of, 224

Cradle of American Indian papoose, I2I

Cranmer, hat of, 159

Crescent as an amulet among the Romans, 219

- made by joining two boars' tusks, 219

- worn on a special strap by German horses, 219

Crest and badge, difference between, 65

- - surcoat of Henry, Duke of Lancaster, 62, 62

- on helmet, 60

- - signet ring, 61, 62

- worn upon cap of Lord Mayor's postilion, 66, 67

Creel carried on a baldric, 77

Crinoline, $25^{\circ}$

- devised to hide the shame of a princess, 256

- of the young women of Otaheite, 250

Croft. School, Fleet, dress worn by girls at, 127, 127

Crombie, Mr. James, on superstitions connected with weddings, I30

Crook, shepherd's, I45

Crosier, I 65

Cross of nuns, $\mathrm{I}_{5} \mathrm{I}$

- older than Christianity, 89

Cross-belt of Rifle Brigade, I79

Crown, I 6,165

- bridal, 132

- Tudor, superseded that of St. Edward, I67, 167

Crusaders, 256

Cuff, turned back, 25, 26, 27, 28

Cuffs, 25

— of widow, I35

- white lawn, used as mourning by King's Counsel, I64

- worn by the legal profession as part of mourning, I35

Cuirass of Household troops, I73

Culloden, battle of, $\mathbf{r} 84$

Currencies carried on the person, 82

- ornaments as, 82

Cussan's "Handbook of Heraldry," II6 
Custom of breaking a coin upon engagement, 84

DALMATIC, I42, I $45, \mathrm{I} 65$

- compared with a shirt, 2I 5

- of Bishop, fringes on, $\mathrm{I}_{42}$ $I_{42}$ deacon, fringes on left side only,

- symbolism of fringes, $\mathbf{I}_{42}$

Damascus, damask takes its name from, 232

Damask takes its name from Damascus, 232

Dane, dress of the, 236

Darnley, Lord, breeches of, 213

Darwin, Charles, on the loss of hair by man, 6

- theory of evolution, 2

- Sir George, on buttons, 22

- - evolution in dress, 2

$-74-$ the origin of busbies, $4 \mathrm{I}$ 44

- - - top boots, 48,49

- - why plumes are on the left side, $4 \mathrm{I}, 43$

D'Aubernoun, Sir John, brass of, showing chain-mail, I 73

David, shield of, 219

Dawkins, Professor Boyd, on the origin of the hair comb, 86

Deacons, stoles of, I 43

Deaths due to painting the face, 207

Decoys, dogs dressed as duck, 224

Deformities caused by bandaging infants, I2I

Demeter, 221

Denmark, dress of Bronze Age chieftains, I 4, 15, 54, 54

Depression in a judge's wig, I6I, 162

Diamond, supposed powers of the, 90

Diamonds, always fashionable, 90

Diaper appeared in reign of Henry II, 232

- derived from D'Ypres, 232

Dinners, handkerchief used for wrapping, I 45

Diodorus on plaid, 231

Distortion of the head, 249

Divorce, Bedouin form of, I3I

Djibah, 126, I27

Doctor in the Punch and Judy show, I95, 197

- of Divinity, scarf of, I43

- round cap of, 160

Dogs, dress of, as duck decoys, 224

- hairless, 226

Doll, with parti-coloured clothes, I98
Dolls, clothes of, Ioo

- costume, I98

- in swaddling clothes, Mr. Edward Lovett on, I98

Dolman of the Hussars, 59, I77

Donkeys, cowry shells on trappings of, 221

Drawings of cave men, $7,7,8$

Dress, academical, I 56

- Druitt on, 157

- bridal, I 29

- characteristic of trades, 237

- children's, Dr. Alice Vickery on, I 2 I

- colour in academical, 230

- condemnation of, by the clergy, 256

- Court, I68

- - mistakes made in, 169

- does not usually show rank, 237

- Dutch skeleton, 105, 107, 202

- evening, black and white, 229

- - suggests correct behaviour, 253

- Highland, II9

- League, Rational, 264

- monastic, I47

- more primitive, worn on occasions of ceremony, 99

- naval, supposed survivals in, I86

- of acrobats, $2 \mathrm{I}_{3}$

- - ancient Christians, 139

- - animals, $2 \mathrm{I} 7$

— - beadles, I07, I94, 196

- coachmen, origin of, IO2

- convicts, 66

- costermongers, 237

- - footmen, origin of, IO2

- - girls at Coombe Hill School, King's Langley Priory, 126, I27

- - - - the Croft School, Fleet,

I 27,127

- - grooms, origin of, 102

_- harlequins, 2II, 211

- heads of churches in Scotland. I 49

- - jockeys, coloured, I06

- King's Counsel, r63

- Knights of St. John of Jerusalem, 238

- monks, 149

- Mrs. Bloomer, 59, 269

- - of Norwegian bride, ${ }^{3} 32$

- nuns, I50, 150

- particular trades, 108

_- peasants, gay, 230

- Punch and Judy, ror, I88

- Romans, 139 
Dress of servants, 102

- - the American, 236

- - - Austrian, 236

- Colonial, 237

- - Dane, 236

- - Frenchman, 236

- - German, 236

- - Hungarian, 236

- - Norwegian, 236

- - Spaniard, 236

- St. Nicholas, I00

- soldiers previous to the Restoration, $\mathrm{x} 75$

- Yeomen of the Guard, I67, 167

- once indicated rank, 237

- origin of, 5

- parti-coloured, came into fashion in Edward II's time, 232

- profession often not indicated by, 234

- rank indicated in certain professions by, 238

- rational, 57, 269

- reform, 264

- simplification of Court, 168

- special, for worship, I53

- tax on elegant, 26I

- to be according to station, 260

- ugliness of evening, 156

- Union, Healthy and Artistic, 264

- used in special occupations, 237

Dresses, bridal, often survivals, I 32

- special school, I24

- with trains to be kept for ceremonial occasions, 267

Dressing-gowns, ' IOI, 267

Drops for ears, $8 \mathbf{I}$

Druitt, Mr., on academical dress, I57

- - boys dressed in petticoats, I2I

- - the coif, 162

Drummer, extra of Third Hussars, I 80

Dutch settler's wife, Miss Alice Morse Earle on the dress of, 268

- skeleton dress, 105, 107, 202

Dyes for tartans obtained from native plants, 232

EAGLES on coronation robe, 165,166 Ear drops, 8I

Ears, perforated for rings, $8 \mathrm{I}$

Earle, Miss Alice Morse, on the costume of the wife of a Dutch settler, 268

Eckenstein, Miss Lina, on horse brasses, 219
Edward II, beard of, 95

- III, badge of, 67

- - beard of, 95

- IV, beard of, closely shaven, 95

- VII, robes worn at the coronation of, 166

Egypt, finger rings in, 83

Egyptian graves, models of servants put into, 199

- pins, 76

- rings of blue pottery, 85

Egyptians, ancient, bury amulets with their dead, 89

- blackening eyelids, 201

- early, tattooing practised by, 205

- modern, tattooing practised by, 206

- prehistoric, beads of, 82

Elizabeth, statute cap of, I23

- Queen, stocking of, 50

Elizabeth's coronation glove, stitching carried on to the back of, 70, 71

- reign, ruffs of, 34

Elsyng, brass in church at, 62,62

Elves' arrows as pendants, 90

Elworthy, Mr., on horns of honour, 85

Embroidery carried on to the backs of gloves, $7 \mathrm{I}, \mathbf{7 1}$

Emeralds always fashionable, 90

Epaulettes, I 75

- worn by the Gentlemen-at-Arms, I76

- - officers of the Yeomen of the Guard, 176

- - the Lords-Lieutenant of Counties, 176

- - in the Navy, I76

Ermine, I66

- bands of, indicate rank, I66

Eskimos descendants of the cave men, 8

- shoes, piece of old, worn by, to ensure fruitfulness, I $_{3}$ I

Essex, fish-hooks made of thorns in, 9 I

Eton collar, 33

- gowns worn by scholars at, I 24

- jacket, I24

- white tie at, 124

Etruscan brooch, safety-pin like an, 74,75

Eutropius, St., ceremony of garters, 52

Evolution, the principles applied to clothes, I

Ewart, Sergeant, captures a French eagle, I8I 
Eyelashes, removal of, 94

- lid, blackening of, by Egyptians, 201

- sacred on rings, 85

- stone or opal, 90

- third in slow worm, 2

Executions, clothes worn at, become unfashionable, 263

FACE, blacking of, 2 Io

- plate of horse, amulets on, 219

- sooty, of harlequin, 210, 211

Facings, regimental, abolished in I 88 I, I77

- why a different colour from that of the coat, 24

Fairholt on bandaged stockirgs, 49, 50

$-\frac{5}{160}$ the origin of the mortar-board,

Fans called sunshades, 208

- for blowing up a fire, 208

- origin of, 207

Farces, Atella, celebrated for Italian, 189

Farthingale, 250

Fashion determines the amount of the body which is to be covered, II

Fashions due to royal peculiarities, 96

- gay, follow periods of depression, 256

- in hair arrangement, 92

- kept up by superstitions, 260

- origin of, difficult to trace, 264

- the killing of, 262

Favours, I43

Fawkes, Guy, 168

Feathers, objections to the wearing of, 88

— of birds of paradise, 88

- - ostriches, 89

- peacocks', unlucky because of eyes, 90

- wearing of, 88

Ficorroni, I9I

Field-Marshal's baton, I66

Fillet, I29

- forerunner of the hatband, 37, 39

- head, Io9

- vestiges of, 37,39

Finn, Huckleberry, 254

- Mrs., on bells derived from flowers, 233

Fireman, helmet of, 44, 45

- private, badge of, 66
Fisher folk, barefooted, 247

Fish, gold, with several tails, 226

-- hook made of a thorn in Essex, 91

Fitzroy, General, I80

Flaccus, Dr. Louis W., on the effect of clothes on the minds of school. girls, 252, 253

- - _ - - preference of girls for different articles of clothing, 253

Flags, heraldic colours of, still worn as favours, 229

Flap, red, on busby, 42, 44

Flash on Court dress, I 70, 170

- of Welsh Fusiliers, 97, 98, I79

Fleshings, pink, of Merveilleuses, 257

Fleur-de-lys, I66, 218

- on braid of drummers of the Guards, I 82

- removed from royal arms, 182

Flower, Sir William, on deforming of the foot, 248

- _ - injuries caused by tight lacing, 240

- - - - the most highly evolved foot, 247

Flowers, chaplet of, used after baptism, I 2 I

- wearing of, 88

- worn at Eton on Fourth of June, 126

- - by a bride, 129

Folds of robes used as pockets by Arabs, 79

Foot, deforming of the, 248

- gear, early, 46

- Guards, drum-major's livery cap, Io6

- Sir William Flower on deforming of the, $24^{8}$

evolved, 247

- stunted, of Chinese woman, 249

- the ideal in art, $247,24^{8}$

Footman, I03, 104, I09

- origin of dress, IO2

Footmen, aiguillettes worn by, I 78

- pocket flaps of, 24, 24

— wig of, 96

- with powdered hair, 95

Fourchettes of gloves; 70,70

Fourragère, 178

Fowls, top-knotted, 226

Fox-hunters, red coat of, 174

Frenchman, dress of, 236

Frills, I69

Fringe of a shawl, origin of, I3 
Fringes, Mr. Macalister on symbolism of, on dalmatics, I42

Frock coat, ro8

Frontal of nun, 150, I5I

Fruitfulness, superstitious practices to ensure, 132

Funerals; horse trappings still used at, 218

-painted pasteboard figures burnt in China at, 203

Fur, 9

- use of, in the army, 183

Fusiliers, Welsh, flash of, 97, 98, I79

Fylfot, 89; see Plate VII, Fig. F. facing page 97

GAGGING, art of, not modern, I 89

Gaiters, 5I

Garlands, wearing of, signifies virginity, 133

Garment, new, put on over old, 108

Garments, dislike of divided, 268

- flowing, give an elegant effect, ror

- - - dignity, I39, 267

- long, of Noah's Ark figures, I98

Garter, II 6

Garters as insignia, 52

— golden, of Merveilleuses, 257

- of girls, annual ceremony in Haute-Vienne, 52

- ornamental, 52

Gatty, Sir Alfred Scott, on cockades, II 2

Gauntlets worn by masons, I 72

Gentlemen of George III's time, I03

George II's reign, coachman, coat of, IO3, 105

- on naval uniform, 186

- III, black coats at Eton, mourning for, 124

- - gentleman's dress, Io3

- III's reign, the pouter coat of, I03, 104

German, dress of the, 236

Germs of disease disseminated by trailing skirts, 267

Giangurgolo, Calabrian (I73I), I9o, 191

Gimmal rings, 84

Girdle, 53

- of judge, 162

Girl catching an object in her lap, 253

Girls, colour preferences of, 228

- in factories, barefooted, 247

- wearing their hair down, I22

Gladstone, Mr., abolished the serjeants-at-law, 162
Gloucesterșhire regiment, badges of, I 8 I

Glove of Anne, Consort of James I, 7I, 71

- stitching carried on to the back of Elizabeth's coronation, 7o, 71

- - down the back of, 70, 71

Gloves, 68, r 45

- early, without fingers, 68

- embroidery carried on to the backs of, $7 \mathrm{I}, 71$

- fourchettes of, 70,70

- not worn by nuns, I5I

- points on, 69,70

- with two thumbs in Iceland, 69

God, solar, of Egypt, 89

Gold dust put on the head, 95

Golfers, red coat of, I 74

Gordon, Miss Helen, on painting used in the time of Queen Anne, 207

Gorget the badge of an officer on duty, I74

Gorilla, hair of, 5

Gown, I4

- black, 137

- Geneva, bands worn with, 32

- of judge, I62

- - King's Counsel, I63

- - Master of Arts, 157

- Oxford Undergraduates, I57

Gowns, black, legal, mourning for Queen Mary II, I62

- worn by scholars at Eton, 124

Greek betrothal rings, 84

Gremial, I50, 150

Grenadier caps of Scots Greys I8I

Greys, Scots, I8I

Grenadier Guards, $r 8_{3}$

Groom, I02, 103

- origin of beit, Io2

- - - dress, 102

Guards, drummers of, fleur-de-lys on braid of, 182

- formation of, by Charles II, I82

- Grenadier, I83

- - buttons on coats of, $2 I$

- Irish, I84

- Life and Horse, survival of cord for priming powder horn, 77

- Scots, 184

- white jackets of, I80

Guignol, I9o

-French punch, 190

- the name derived from Giangurgolo I9I 
Guild liveries, $\mathbf{I} 72$

Guinea, New; women wear no clothes, 7

HABIT, black of clergy, 229

Habits, monastic, I 47

Hackle feathers of Northumberland Fusiliers, I $8 \mathrm{I}$

Hair, clubbed, 98

- curly, imitated, 95

- dedication of, 93

- dishevelling of, as mourning, I34

- down, girls wearing their, 122

- early man covered with, 5

- great value attached to a profuse head of, 93

- long, not necessarily effeminate, 92

- not correlated with cold climate, 5

- of women dressed differently from that of men, 94

- powder, 95

- - coloured, 95

- putting up of, by girls, 122

- queued, 98

- Roman modes of doing the, 96 ; Plate VII, facing page 97

- use of others', 95

Halberds of Yeomen of the Guard, I68

Handkerchief in general use in Henry VIII's time, I45

- used for wrapping up dinners, I45

- - - - presents, I45

Hanover, cockade of House of, III

Harem, Io

Harlequin, I94, I97, 2 I0, 211

- coat of, worn by the Lord of Montbron, 2 II

- modern dress of, 2 I I, 211

- origin of the character, 2 Io

- patched coat of, 2 IO

- shaven head of, 2 Io

- sooty face of, 2 IO

- wand of, 2 II

Harlequinade, 200, 210

Harlequinne, 2 I2

Harrow, coats at, 124

- swallow tails at, I25

Hat band, 37

- - origin of, 37

- cocked, development of, 44, 45

- Cranmer's, 159, I6o

- for hunting with lacing, 40, 42

Hat, how made from a disc of material, 4I, 43
Hat of a bishop of the Stuart period 159, I6o

- sailor, streamers of, 39, 40

- tall, used in the Army, I 83

Hats with the underside painted green, 20I

- women in church without, ${ }_{54}$

Haweis, Mrs., dressing to suit her surroundings, 230

Hawaïian Island, hut of, 36

Haybands forerunners of leg bandages, 49

Head, distortion of, 249

Head-dress of French lawyer, II5 - _- Henry II's reign surviving in that of nuns, I49, 150

- - shawl as a, 45

- - Siamese, compared with a Votive Spire, 37,38

- shaven, of harlequin, 210

- shaving, 93

- strap, I5I

Heads, deforming of children's, by Chinook Indians, 248

Hearse cloth, I72

Heart-shaped amulets, 220, 220

Hector, the horse, extinct in Punch and Judy show, I98

Helmet of Black Prince, 63, 63

- fireman's, 44, 45

- plate, II6

Helmets, metal, 44

Henna used for staining fingers and toes by Egyptians, 202

Henry VIII's reign, handkerchief came into general use in, $\mathbf{I}_{45}$

Heppel, Mr. George, on Punch and Judy, I 88

- _ - figures worked by wires, I89

Heraldry, Handbook of, by Cussan, II6

Heralds, tabards of, 60

Hereditary badges, 65

Hide, raw, shoe made of, 47,48

Highland corps, white jackets of, 180

- dress, II9

Hindu ayahs, nose rings of, $8 \mathrm{I}$

- women, painting of the feet scarlet by, 203

— - teeth blackened by, 203

Hodgson, Miss, uses a doll to show costume, 128

Hogarth's engravings of children, I 9

Holland, dress of clergy in, $14^{8}$

Holy Land, swaddling clothes persist in, 120,247 
Hood, I 47

- academical, I57

- wearing of, by clergymen, $\mathrm{I}_{4} 8$, I 58

- combined with cape, II4, 114

- enlargement of the peak, I I4, 114.

- of a Knight of the Garter, I7I, 171

\section{- Bachelor of Arts, I58}

- nuns, I5O, 150

- - the Order of the Thistle, I7I

\section{- - - St. Patrick, I7I}

- - undergraduates, liripipe of, $\mathbf{I}_{5} 8$

- peak of prolonged, to form liripipe, II 4,114

- tiny, on barrister's gown, 163,164

Horn for priming powder, survival of cords for suspending, 79

Horns of Honour, 85

Horse amulets, 21 $8,219,220,220$

- brass, crescent shaped, derived from boar's tusks, 219, 220

- brasses, English, the counterpart of those shown on Trajan's column 220

- - Dr. Plowright on the origin of some, 218

- Miss Lina Eckenstein on, 219

\section{- heraldic, 220}

- clothing, 218

- identified as a corn spirit, $22 \mathrm{r}$

- shoe as an amulet, 219

- trappings, 218

- - still used at funerals, 218

- white, of Hanover, I79

Horses, black, used at funerals, 226

- circus, 226

- grey, carry the kettledrums, 226

- hats of, 224

- killing of, at harvest time, 22 I

- sun-bonnets, 224

- white carry the kettledrums, 226

Hose, Florentine, 52, 213

- tights, a survival of Florentine, $2 I_{3}$

- trunk, 200

_- of acrobat, $2 \mathrm{I}_{3}$

- - - clown, 200

- - - knights, I7I

Household cavalry, bandsmen's livery caps, Io6

Housemaid, apron of, 108

- cap of, 108

Hounds, Dalmatian, as carriage dogs, 226

Howard of Effingham, hat of Lord, I 83

Hump of Punch, back, I94, 194.

- - front, origin of, 188
Hungarian, dress of the, 236

- peasant's cap, 42,44

Huntsman, livery cap of, Io6

Hussars, 42

- cowry shells on trappings of horses of, $221,222,222$

- dolman of, 59, I 77

- Eighth, wear sword-belts over their shoulders, I8o

- Eleventh, wear ivory-hilted swords, I8I

- Fifteenth, wear Austrian imperial lace, $18 \mathrm{I}$

- lacing of, I05

- prickers on shoulder belt of, I77.

$$
177
$$

- sling jacket of, 59, I77

- Third, extra drummer of, I80

- uniform of, $2 \mathrm{O} 2$

Hut of Hawailian Islands, 36

ICELAND, glove with two thumbs, 69 India, lotus flowers on king's mantle,
symbolical of, I 66

Indian Army, puttees of, 49

Infant, bib of, I 23

- binder of, I20

Infantry, uniform of goth Light, 27

Infants, deformities caused by bandaging, I $2 \mathrm{I}$

- patched, II9

- powdered, II9 Inner Temple, badge of the porters

Ireland, pin-ring brooches in, 9I

Irish Guards, I 84

Ironside of Cromwell compared with a modern cavalryman, I75, 176

Italian women age rapidly, 244

JACKET, Cardigan, I4

- Eton, I24

- smoking, suggests relaxation, 252

Jackets, rainproof, for cows, 224

- white, of Guards, I8o

- - Highland corps, I80

Japan, use of paint by women in, 204

- children, painting the face of, 203 - women, teeth blackened by, on

Java, earliest man in, 5. See Frontispiece. Jerome, St., on special dress for
worship, I $_{53}$

Jesson, Mr. W. H., a performer of 
Jesus College, Cambridge, choristers' bands, 32,33

Jewesses shave their heads, 93

Jews, 153

- rending their garments, 30

- tattooing practised by, 205

Joan the old name of Judy, 197.

Jockey, livery cap of, I06

- parti-coloured dress of, I06, 232

Johanna, 224

Judge, girdle of, $\mathrm{I} 62$

- gown of, 162

- sentence cap of, I62

- wig of, 96, 16I, 162

Judith, I97

Judy, dress of, I94, 195

- apron of, 195

- mob cap of, I94, 195

- once known as Joan, I97

- origin of the name, 197

KAMARBAND worn by officers, I 84

Kayans of Borneo, clothes of bark worn by, as mourning, I34

Kefiyeh fastened with a fillet of camel's hair, 39

Kersey, 26r

Kettledrums, silver, I8o

Kilburn Sisters, I49, I50

Kilt of sailors, 187

- short, 55, 56

Kimono brought from Japan, 256

King's Counsel, dress of, I63

- - gown of, I63

- - white lawn cuffs used as mourning by, 164

- footmen, red coats of, I74

Kirkcudbrightshire, pin-ring brooches of blacksmiths in, 9I

Knee-breeches worn when speeches are made at Eton, 125

Knickerbocker suits, jersey, I2I

Knickerbockers, 57

- of blue-coat boys, I23

- a recognised feature of children's costume, 120

Knights of the Garter, I70

- - - chaperon on robes of, II 5

- - St. Patrick, I 7o

- - the Thistle, I70

Knobs in the East take the place of buttons, I 5

Kohl, 2OI

LABEL to difference arms, $62,63,65$

Labourers' method of buttoning trousers 187
Lace, Austrian imperial, worn by Fifteenth Hussars, I8I

Lacedæmonian girls, tunics of, slit down the sides, 256

Lacerna, 147

Laces, 73,74

Lacing inside a hat, 42

- of Hussars, I05

- tight, banned by Charles IX and Henry III, 242

- - in England, 242

- made compulsory by Catherine de Medici, 242

Ladies, armorial bearings on dresses of, 61,62

- married with flowing tresses, I22

- wear pyjamas, 2I 5

Lady gardeners at Kew wear trousers, 267

Lake dwellings, pins found in Swiss, 76

Lamb, Persian, used for making spots on miniver, 166

Lambs that supply the wool for the pallium, $\mathrm{I}_{4} 6$

- waterproof coats of, 224

Lancaster, Henry Duke of, crest and surcoat of, 62, 62

Lancers, 27

Lap, boys and girls catching objects in their, 253

Lawn sleeves of a bishop, $\mathrm{I}_{4} 8$

Laws for the good of trade, 259

Lawyer, head-dress of French, II5

Leech, caricatures the busbies of the Guards, I 83

Leg bandages, $49,50,50$

- - derived from haybands, 49

- - of pfiferari, 50

Leggings, survival of the wearing of skins, $5 \mathrm{I}$

Legion of Honour, buttons of, II6

Leicestershire Regiment, tiger-skin aprons of, 184

Leopards on Arms of Engiand, 63

Life Guards, black plumes of farriers of, I 79

- - - tunics of farriers of; I79

Light Infantry, Duke of Cornwall's, puggaree of, I80

Lindley, Lord, last surviving serjeant-at-law, I62

Linen, strip of, round head as mourning in Egypt, I35

- the showing of, 3 I

Lion spotted when young, 68

Lions on Arms of England, 63 
Lip plugs; $8 \mathrm{I}$

Liripipe, II 4,114, I 57 , I 7 I

- of undergraduates' hoods, $\mathrm{r}_{5} 8$

- peak of hood prolonged to form, II 4,114

Liveries of the City Companies, I72

Livery cap, Io6

- of bandsmen of the Household Cavalry, Io6

- _ drum-major of the Foot Guards, 106

- - - jockeys, ro6

- - - huntsmen, 106

- Companies, chaperon, vestige on gowns of, 172

— of page-boy, I05, 107

- - porters, 107

Locket, 89

Loom combs, 85,86

Lord Mayor's coachman, wig-bag of 98

- postilion, crest worn upon cap of, 66,67

Lotus flowers, symbolical of India, on Edward VII's mantle, I66

Louis XIV, hair of, gave rise to wigs, 96

Louterell, Sir Geoffrey, figure showing armorial bearings, 61,62

Lovett, Mr. Edward, on dolls in swaddling clothes, 198

- - - origin of pin-ring brooches, 9I

tattooing, 206

Lyman, Dr., explanation of buttons being differently arranged on the clothes of the two sexes, I 6

Macalister, Mr., on fashions, I4I - _ - symbolism of the fringes on dalmatics, $I_{42}$

- - the pallium, 146

- - - surplice, 138

- - there being no distinctive garments for the ministers, among early Christians, I4I

Macphersons, tartan of the, 232

Magnin, M., on the origin of Punch's hump, I93

Mail, chain, vestige of, on shoulder of Imperial Yeoman, 173,173

Mail, plate, I 74

Malachite used for painting by prehistoric Egyptians, 201

Man cook, white clothes of, 237
Man, Isle of, triskele in the coat-ofarms of, 86

- once hairy, 5. Frontispiece

- skin of, originally reddish, ro

- primitive, 3

Manche, 106

Maniple, 165

- once a napkin, 145

Manning, Mrs., hung in a black satin dress, 263

Manservant, modern, I04

Mantle, imperial, I65

- of Edward VII, lotus flowers on, I66

- - Queen Victoria, roses, on, I66

Mantles of ladies, collars standing up 34

Maoris, tattooing of, 205

Mare, the last uncut ears of corn, 22 I

Markan, women of, floral designs on the bodice, 206

Marines, Royal, mourning of, I8o

Marionettes, I 89

Marriage by capture, 129

Marriot, Mr., on the colour of early vestments, I4I

Martingale of horse, amulets on, 219

Mask, unwritten laws that rule the wearing of, 208

Masks of the 5 th of November a reminder of primitive face-painting 208

- worn by savages, 208

Mason, Mr. Otis T., on pockets, 79

Masons, aprons of, I 72

- insignia of, I 72

Master, clothing of, becomes that of servant, 4 , III

Maud, I4

Maundy Thursday, 168

Mayhew, Mr. Henry, on Punch and Judy, I96

Medical officers, volunteer, wear cocked hats, I 82

Men, colour preferences of, 229

Merveilleuses, 256, 257

Mess jacket of Somersetshire Light Infantry, I 79

Meyer, Dr., on the padding of sleeves above the shoulder to prevent weapons from slipping off, $25 \mathrm{I}$

Mice, piebald, 226

Milk-women, apron of, Iog

- costume of, 80

- - with yokes, 80

Milton, bands of, 33 
Mimes, Roman, 136, 2 Io

Mimi, 210

Miniver, 166

- rows of black spots on, indicate rank, I66

Mitten, open work, 7 I

Mittens and tattooing, 72

Mitre, 165

- strings of, 39, 41

Mizpah rings, 84

Mob cap worn by Judy, I94, 195

Modesty a habit, 9

- different ideas of, in various regions, 9

- ideas of, Arab women, I 54

Molière introduces Punch into Le Malade Imaginaive, I92

Monk, General, 182

Monkeys, clothes of, 224

Monk, dress of, I 49

- scapular of, I49

- tunic of, I49

Montbron, Lord of, harlequin's coat worn by, 2 II

Montagu, Lady Mary Wortley, and painting, 207

Montaigne on the sufferings caused by the corps piquè, $24 \mathrm{I}$

Montem at Eton, I26

Moore, Sir John, black worm as mourning for, 179

Morrison, Mr. W., on the origin of the mitre, 40

Mortar-board, 33, I24, I59, 159

Moseley, Professor, on face-painting in China, 203, 204; see Plate $X$, fig. $C$ facing page 200

_ - painting the body, 202

- - the use of paint by women in Japan, 204

Mosque-like turban, 36,37

Mourning bands of barristers, I64

- black as, I34

- black band on arm for, 135

- - worm for Sir John Moore as I79

- clothes of bark worn by Kayans of Borneo as, I34

- cuffs worn by the legal profession as part of, I 35

- dishevelling of hair as, I34

- for death of Nelson, I86

- General Wolfe, black worm as, I 79

Mourning, of Royal Marines, r8o

- purple as, I34

- sackcloth as, I34
Mourning, strip of linen round head in Egypt as, I35

- white as, 134

- - lawn cuffs used by King's

Counsel as, I 64

- yellow as, I35

Moustache, 94

Mules, cowry shells on trappings of, 22I, 223

Mutes at children's funerals, $\mathbf{x} 34$

NAIL, horseshoe, as part of a pinring brooch, 9I

Nakedness, effect of, destroyed by tattooing even in Europeans, 206 Napkin, 145

Naval uniforms, I86

Navvies wear belts, 244

Neapolitan, the, as an actor, I 89 Neck chains, 82

- - of Richard II's time, 82

Nelson, mourning for death of, I 86

Neuville, M. Lemercier de, on Punch's stick, I92

Newcombe, Allan Poe, on hats and habitations, 36

Nicks in coat lapels, 30,31

Nightcap of man, 216,216

- woman, 215, 216

Nightcaps, elaboration of, restricted in the reign of Mary, 216

— of Tudors, 216

- still worn, 216

Night-dresses worn by ladies in the street in Anne's reign, 216

Nightgown, the bands on a lady's, 2 I 5 Night rails, 216

Nightshirt cut like a day shirt; 2I4

Noah's Ark figures, long garments of, 198

Norman chin-band, I5O, 151

Normans closely shaved their beards, 94

- combination garments of, 237

- wore trousers, 57

Northumberland Fusiliers, hackle feathers of, I8I

- - wear roses, $18 \mathrm{I}$

Norwegian, dress of the, 236

Nose rings of $\mathrm{Hindu}$ ayahs, $8 \mathrm{I}$

Novice, veil of, 150

Nuns, I49, I 50

Nuns, aprons of, I 5 I

- breast cloth of, I 50, 150

- cap of, I5O, 150, I5I

- collar of, I 50 
Nuns, costume of, 147

- cross of, I5I

- frontal of, 150, I5I

- hood of, I5O, 150

- not allowed to wear gloves, $\mathbf{I}_{5} \mathbf{I}$

- scapular of, I5I

— veil of, I50, 150

- wear wedding-rings, I5I

Nurse, hospital, uniform of, IIo

Nurses, domestic, imitating hospital nurses' dress, II

O'Connor, Dr. Bernard, on bloomers, 269

_ _ _ - woman's dress for active exercises, 269

Officers, commanding, choice of uniform, I79, 180

- non-commissioned, stripes on sleeves of, 83

Opal, supposed powers of the, 90 Opals, always fashionable, 90

- and bad luck, 90

Openwork mittens, 7 I

- of Roman shoe, 46,47

- stocking, 5I, 52

Ophal, 90

Orange blossom, I33

Orang-utan, hair of, 5

Oraria, distribution of, by Aurelian, $\mathrm{r} 43$

Orarium, I $42, \mathrm{I} 45$

Order of the Coif, I62

Origin of fashions difficult to trace 264

- mayoral chains, 82

- - the clock, 50

Ornament, love of, among simple races, 7

Ornamentation of modern boots, 46 ,

- - shoes, 47

Ornaments as currencies, 82

— of Stone Age, 82

- serve for identification, 8

— shells as, 82

- why they survive, $8 \mathrm{I}$

- worn even if there are little clothes 7 ; see Plate II, facing page 8

Orphrey, the apparel of the chasuble, I 46

Ostrich feathers, 89

Oxford University, Chancellor of, hanging sleeve of, I $_{57,158}$

Oxford University, undergraduate's gown, 157

Overcoat, 108
PADS in hair dressing, 95

Padding, 250, 25I

Page-boy, buttons of, I05, 107

- - livery of, 105, 107

Pageants, success of, a sign of the craving for colour, 227

Paint on face of clowns, 200

- use of, by women in China, 204

- - - - Japan, 204

- - at a corroboree, 202

- - in war to terrify, 202

Painted pasteboard figures burnt at funerals in China, 203

Painting, Io

- by native races, 202

- follows the bones of the body, 202

- of clowns likened to that once in vogue in China and Japan, 205

- - the body by cave men, 200

- practised by civilized men, 208

- the body among Andaman Islanders, 205

- - Professor Moseley on, 202

- - eyes, practised by the prehistoric Egyptian, 6000 B.c., 20I

- - face to hide the ravages of time, 206

- _ - heighten its beauty, 206

- - deaths due to, 207

- - of Japanese children, 203

- - - - actors, 203

- - feet scarlet by Hindu women,

Palettes, slate, in the form of two birds in prehistoric Egypt, 220

- - of the New Race, 201

Pall, I46

- manufacture of, I 46

Pallium, I46

- development of the, I 46

Palmerston's, Lord, broad-toed shoes, 248

Panache derived from the horn, 86

Pantaloon, I89, I94, 2II, 2 I2

- Elizabethan costume of, 200, 2I2, 212

Pantomimes, 200, 210

Pantomimi, 2Io

Papoose, swathing of American Indian, I2I

Paré, Ambrose, on the suffering caused by the corps piqué, 24I

Paris, waistbands, trade in, discarded, 259

Parliamentary officials, wigs of, 96

Parti-coloured dress of Athletic clubs, 233

__ - jockeys, Io6, 233 
Patches indicating political views, 207 - of Charles I's reign banned by the Puritans, 207

- reappear in Charles II's reign, 207 Pattern, pine, origin of, 23I

Patterns, breeches of chequered, worn by Gauls and early inhabitants of England, 23 I

Peasant dress, slight survivals in England, I09; Plate VIII, facing page IIO

Pelisse obtained from Persia, 256

Pendants, 89

Pensioners, costumes of, I25

People, uncivilized, without pockets, 7

Persian women wear trousers, 57

Perthshire, the bare feet of children in, 247

Petrie, Professor, on Romano-Egyptian portrait models; 96

- - buttons in Egypt, 88

- - the origin of a supposed shield-shaped ornament, 220

Pet animals, collars worn by, 222

Petticoat at first not shaped, 54

- hooped, 250

Petticoats, lengthening of, I22

- of sailors, 187

_- small boys, I2I

Pfiferari, cross gartering of, 50

- leg bandages of, 50

Phallic worship, 89

Pig-tail, grease of, I87

Pileus quadratus, 159

Pillion, 102

Pin, safety, 74, 86

- in hat, 75,77

_- waistband, 75,76

- - like an Etruscan brooch, 74. 75

- scarf, 86

Pinafore, 109

Pinafores now children's dress, I23

Pin-money, 76

Pinner, 109

Pins, bronze, 76

- Egyptian, 76

- found in Swiss Lake dwellings, 76

- gold, I46

- made of thorns, 9 I

- of bone, 76

- ornamental, 76

- scarf, 76

Fithecanthropus erectus, 5

Plaid, I4, I 39

- belted, 53
Plaid, shepherd's, 23 I

Plaids, 231

Plastron of Hussars, 108

Plowright, Dr., on the Moorish origin of some horse brasses, 218

Plugs for lips, 8I

Plumes, black, of farriers of Life Guards, I 79

- why on left side, 4 I

Plush, Io9

- breeches, I03, 104

Pocket flaps, vestiges of, 24,24

Pockets, 79

- in the sleeves of a Korean, 79

- side, 23

- uncivilized people without, 7

Points, 70

- on gloves, 69,70

Policeman's coat, buttons on the back of, 20, 20

- uniform not worn by children, II9

Polly, Miss, in the Punch and Judy show, now extinct, I96

Polypus ( $=$ the octopus) changing colour, I 54

Porters, livery of, I08

- railway, waistocats of, 108

Portugal, Queen of, demonstrates the evils of tight-lacing by means of radiographs, $24 \mathrm{I}$

Postilions, buttons on jackets of, 27

- coats of His Majesty's, I05

- of Lord Mayor, crest worn upon cap of, 66,67

Postulant, veil of, I 50

Poupée derived from pupa, I20

Pouter coat, I03, 104

Powder, I09

- for hair, 95

Prayer-book, first, of Edward VI, ornaments, rubric of, - upheld by Act of Uniformity, I47

- - second, of Edward VI, I48

- - vestments prescribed by the, first, of Edward VI, I47

Prickers on the shoulder-belt of a Hussar, I77, 177

\section{Priest, 144}

Profession indicated by costumes, 234

Puggaree of Duke of Cornwall's Light Infantry, I80

Pulicinella, I\&9

- means a hen chicken, 195

Pulicinella, Oscan, of I73I, 190

Punch, I94, 194

- a Roman mime, 136

- and Judy, dress of, IoI 
Punch and Judy show, beadle of, 107, I94, 196

— - doctor of, I95, 197

- - - Hector, the horse, extinct in, 198

- _ - Miss Polly, now extinct in, 196

- back hump of, 194, 194

- bronze statuette with face and features of, I9I, 192

- figures worked by wires, I8g

- front hump of, I88, I92

- gay clothes of, in France and England, I94

- in religious plays, 197

- introduced into Le Malade Imaginaire, by Molière, 192

- origin of clothes of, I9o

- - , hump of, 188, 192

- ruff of, I94, 194.

- stick of, 192

- the behaviour of, changes, I95

- voice of, I95

Pupa, Greek name for a baby in swaddling clothes, I20

Puppet derived from pupa, I20

- show of fourteenth century, IgI, 193

- shows in China, I9I

Puritans and Quakers, fashions set by, 259

Purple as mourning, I34

Puttees, 49, 50, 243

- of Indian Army, 49

Pyjamas, Ior

- worn by ladies, 215

Pym, John, bands of, 33, 34

QUAKERs refused to wear buttons, 87

Queued hair, 98

Quiver carried on a baldric, 77

RA, 89

Ramillies, battle of, I8I

Rank once indicated by dress, 237

- indicated by dress in certain professsions, 238

- not usually shown by dress, 237 Rats, white, 226

Red cap of liberty, 228

- not universal in the British Army, 229

- rag of chulos in the bull fight, 228

- ribbon of engaged girl, 228

Red rose of Lancaster, 228

- shirt of the followers of Garibaldi, 228

- tie of platelayer, 228
Regimental badges, I79, I8I

Revers buttoned back, 27, 29

Reynolds, Mr. P. W., on the survival of a button, $\mathrm{I} 84$

- _ - - _ - forage cords, I 78

Rhead, Mr., on the festal dress of Otaheite, 250

Richard II's time, chaperon of, II4

Rifle Brigade, busby of, I79

- - cross belt of, I79

Ring, $\mathrm{I}_{45}$

- for nose of Hindu ayahs $8 \mathrm{I}$

- in Ireland, bearing clasped hands, 84

- of Bishop Agilbert of Paris, 83

- wedding, remains of a door key, 84

Rings, betrothal of Greeks, 84

- - Romans, 84

- engagement, 83

- Egyptian, of blue pottery or faience, 85

- Episcopal, 83

- finger, in Babylon, 83

- - Egypt, 83

- for ears, $8 \mathrm{I}$

- gimmal, 84

- in which the stones stand for letters, 85

- sacred eye on, 85

- signet, 6o, 61

- - in Egypt, 83

- suspended from the neck, 85

- used as an insignia of rank by Romans, 84

- wedding, 83

- - worn by nuns, ${ }^{5}$ I

- why worn on third finger, 84

Robe, parliamentary, of the King, I 66

- coronation, eagles on, ${ }^{6} 65$

Robes of companies, IOI

- a chancellor of a university, I 57

- borough councillors, IOI

- - the Barons of the Exchequer, 163

- worn on State occasions, Ior

Robinson, Commander, on naval uniforms, 187

Robley, General, collection of Maori heads, 205

Rochet, I48, I65

Roman betrothal rings, 84

- d'Alexandre, MS. of, I9I

Romans cut their beards, 94

Romans did not wear trousers, 56

- shoes of open work of, 46,47

- tunic of, I 42 
Romans use rings as insignia of rank, 84

Roses on Queen Victoria's mantle,I66

- worn by Northumberland Fusiliers I8I

$-\frac{1}{I 8}-$ soldiers on St. George's day,

Roy and Adami, Professors, on the beneficial use of waist belts and stays, 246

Royalty, fashions arising from deformities of, 256

Rubies always fashionable, 90

Ruff, Elizabethan, of Toby, I88

- of Toby 188

- worn by Punch, I94, 194

Ruffles, I69

Ruffs of Elizabeth's reign, 34, 26I

Russia, boots of bridegrooms removed by brides in, I3I

SACKCLOTH as mourning, $\mathrm{I}_{34}$

Safety-pin, 74, 75, 75, 76, 77, 86

Sailor suit, I I9

Sailors, European, tattooing practised by, 206

- kilt of, I87

- petticoat breeches of, I87

- petticoat of, 187

- trousers, method of buttoning, 187

St. Clement on women covering their heads in church, $153, I_{54}$

- George, cross of, II6

- Gregory the Great, costume of, I 40,140

- John of Jerusalem, dress of Knights of, 238

- Lucia, I8I

- Nicholas, dress of, Ioo

- - figure of, shows old dress, I98

- Patrick, hood of the Order of, I7I

Sapphires always fashionable, 9o

Saragossa, battle of, I80

Sashes meant to be used as slings, I 79

- of officers, 184

- worn over the left shoulder by sergeants of the Twenty-Ninth Foot, 184

Satchel carried on a baldric, 77

Savage, the female-a Merveilleuse dress, 257

Savages, colour preferences of, 228

Saxons parted or trimmed their beards, 94

- wore trousers, 57,58

Scapular of nuns, I $5 \mathrm{I}$

Scaramouch, I89, I94

- a pantomimist, 212
Scarf, I $42, I_{4} 8$

- on ladies' hats, Iog

- pin, 86,

Scarves, $\mathrm{x}_{42}$

Sceptre, I65, 226

School, Blue-coat, I23

- Bristol Red-Maids, I24

- Wells Blue-Maids, I24

Schools, Green-coat, I24

- Grey-coat, I24

Scotland, dress of heads of churches in, 149

Scottish Rifles, Shako of, I79

Scots Greys, I8I

- - take their name from their horses, 226

- - Grenadier, caps of, I8I

- Guards, I84

Seal of Solomon, 219

Serapis, crown of, 85

Serjeant-at-law, Lord Lindley, last, I62

- coif of, I62

- robes of, $\mathrm{I} 63$

- wig of, I6I

Sergeants of Twenty-Ninth Foct wear sashes over their left shoulders, 184

Servant, clothing of master becomes that of, 4, IO2

Servants' dress, I02

Sex idea, I22

" Shabbies," r99

Shako of Highland Light Infantry, I 79

- - Scottish rifles, I79

Shamrock, I66

Shapka, I77

Shaving carried out with flint knives or pieces of shell, 93

- of heads by Egyptians, 93

- - - East End Jewesses, 93

- the whole head, 93

Shawl, I3

- as a head-dress, 45

- the ancestral, I2

- used as kilt by Danish chieftain, 53,54

Shells as ornaments, 82

- cowry, on trappings of camels, 22 I 223

- - - donkeys, 22 I

- - - Hussars, 22I, 222

- - - mules, 22 I, 223

Shephèrd, plaid of, 231

Shield, 60

- heart-shaped, derived from a double bird, 220

— of Black Prince, 63, 64 
Shield of David, 2 I9

Shirt front, origin of the, 3 r

- survival of the, as an outer garment, 215

Shoe made from a flat piece of hide, 48

- money in Bulgaria, I30

- of raw hide, 47,48

Shoes, broad toed, of Henry VIII's reign, 248

- gift of, by bridegroom to bride, 130

- high heels of, 249

- old, thrown at weddings, r30

- ornamentation of modern, 47

- part of wages, I3I

- pieces of old, worn by Eskimos to ensure fruitfulness, I3 I

- removed from dead bodies to lay ghosts, I3I

- with preposterously long toes, 260

- thrown over the heads of the O'Neils by the O'Cahans, I3I

-

Shoulder knot, use of, 176

Siamese women wear trousers, 57 ; see Plate $V$, facing page 57

Sicily, triskele in the coat-of-arms of, 86

Sign of the "Crooked Billet," Io6

Signs derived from Royal badges, 66

Silk, forbidden, $26 \mathrm{r}$

- stockings, I03, 104.

Simkin, Mr. R., explanation of the flash, 98

Sisters, lay, I $5 \mathrm{I}$

- Kilburn, I49, I50

- of Mercy, I 49

Skeat, Mr. W. W., on glove seams, 7 I

Skeleton dress, Dutch, I05, 107

"Sketch, The," on cockades, II6

Skip, black cap of, Io6

Skirt, Harem, 267

- long, dangerous nowadays, 267

- - disseminates germs, 267

Skirts, short, a recognized feature of children's costume, I2o

- simple, of a Danish chieftainess, 54

- of lady gardeners damaged the plants, 267

Skull on head-dress of Hussars, I05

Skulls, bone inserted into prehistoric, 249

Sleeves, costume dated by, I 57

- detachable, of nuns, I5I

- hanging, I 56, 157

Sleeves, hanging, of a chancellor of Oxford University, 158

- slashed, prohibited, 260
Sleeves, velvet, of a Proctor, 238

Sling jacket of the Hussars, 59, I77

Smock-frock, 14,15

Socks, 49

Soldiers, armlets conferred on, 83

- boys dressed as, Ir 9

- dress previous to the Restoration, I 75

Solicitor of Guards, uniform of, 182

- _ - cocked hat of, 182

Solomon, seal of, 2 r9

Somersetshire Light Infantry, cavalry mess jacket of, I79

Soul remaining in shoes, I3I

Spaniard, dress of the, 236

Spatterdashes, $5 \mathrm{I}$

Spencer, Herbert, on fashions, 255

Spire, Siamese head-dress compared with a votive, 37,38

Sporran, 55, 56

Spur leathers, I74

Staff, cross, I 45

- pastoral, I 45

Star, I 6

Statuette, bronze, of Punch, I9I, 192

Statute cap of Elizabeth, I23

Stays, original intention of, 240

- Professors Roy and Adami on the beneficial use of, 246

- theory that they are derived from swaddling clothes, 246

Steen, Jan, bands of, 32, 34

Stick of camel driver survival of a sceptre, 226

Sticks, walking, 90

Stitching carried down the back of gloves, 70,71

Stoat, 166

Stockings, 49, I 45

- embroidered, 5 I, 52

- leather, worn by William Penn, 5 I

- of cloth, 50

- open work, 5 I, 52

- silk, I03, 104

- yellow, of blue-coat boys, I23

Stocks of leather, I 49

Stole, I44, I65

Stoles of deacons, $\mathrm{I}_{43}$

Stone Age, ornaments of, 82

Stones, precious, fashions in, 90

- - supposed attributes of, 90

Straps, shoulder, 54, 55

Straw wisps on horses, 22 I

Streamers of sailor hat, 39,40

- - Scotch cap, 39, 40

- on barristers gowns, I64

- - hats, 37,39 
Streamers on head-dress of twelfth century, 39, 41

Strings, cap, Io9

- on mitres, 39,41

Stripe on trousers, vestige of a row of buttons, 59,59

Stripes on sleeves of non-commissioned officers, 83

Stud, 86, 87

Suit, sailor, I I9

Sumptuary laws, 26o, 26I

- a hindrance to trade, 26I

- - usually a failure, $26 \mathrm{I}$

Sun-bonnet of barge women, 45 ; see Plate VIII, facing page IIo

Sun-bonnets of horses; 224

Superstitions keep up fashions, 260

Surcoat, 6o

— of Black Prince, 63, 64

- Henry, Duke of Lancaster, 62, 62

Surgeons of the Life Guards wear cocked hats, 183

Surplice, I38, I45, I48

- academical hood worn by clergy on a, 158

- Mr. Macalister on the, 138

- slit in front in order to go over big wigs, 138

Survivals of trade costumes (butchers), 229

- supposed in naval dress, I86

Surtout, 108

Suspenders, 52

Swaddling clothes still used in the Holy Land, 247

- - theory that stays are derived from, 246

Swallow-tail coat, evolution of, 24 , 25,26

- tails at Harrow, I25

Swastika, 86, 89; see Plate VII, figure $\mathrm{F}$, facing page 97

- the forerunner of the cross, 23 I

Sword belt, not worn outside the coat, 20

- handle, opening for, in coat, 23

- in Court dress, I69

- ivory hilted, worn by Eleventh Hussars, I8I

TAB on soldier's coat, 2 I, 22

- - side of coat, 22, 23

Tabards of heralds, 60

Tags, metal, 73, 74

- ornamental, 73,74:

- useless on top boots, 48,49
Tailor and Cutter, Editor of, on clothes and nationality, 236

Talismans, wearing of, by ancient Egyptians, 89

Talith, I 53

Tannin preserves woven material, I4

Tapir, spotted when young, 68 ; see Frontispiece

Tartan, Cameron, I 79

- wearing of, forbidden, 26I

Tartans, Royal Stuart, 232

- of Scotch clans, 232

- dyes for, obtained from native plants, 232

- clans with several, 232

Tattooing, Io

- and mittens, 72

- destroys the effect of nakedness even in Europeans, 206

- effect of, produced by open-work stockings and blouses, $5 \mathrm{I}$

- of the Maoris, 205

- practised by early Egyptians, 205

- - European sailors, 206

_ _ - modern sailors, 206

- - Jews, 205

_ _ - practised by old inhabitants of this country, 205

- scar, as a means of recognition, 205

Tax on elegant dress, 26I

Teeth blackened by Hindu women, 203 - - Japanese women on marriage, 203

Thistle, hood of the Order of the, I 7 I Thistles, I66

Tie, white at, Eton, I24

Tierra del Fuegians, 8

Tights, 52

—of acrobats, 213

- a survival of Florentine hose, 213

- - knightly orders, I7I

Tippet, I 43. I $_{58}$

Tippets of Doctors of Divinity, scarlet, I 58

- for ministers who are not graduates, 148

Tobit, dog in the Book of, suggested by Toby, 197

Toby, Elizabethan ruff of, I 88

Toby represented in China by a dragon; I98

- - France by a cat, 197

- ruff of, I95

- suggests the dog in the book of Tobit, 197

Toga, I39 
Toga, replacement of, 143

- when worn, I39

Toledo, Fourth Council of, I43

Tonsure, I62

- of priests, 93

Topaz as a detector of poison, 90

"Toothpick" collar of dress coat, $3 \mathrm{I}, 32$

Top-coat, Io8

Trades, characteristic dresses of, 237

Trajan, trousers shown on the column of, 56

Tramway drivers, buttons on back of the coats of, 22, 22

Treble, cockade, large, 111

Trencher, 33, I60

Triangles, mystic interlaced, 218

Trimmings of judge's gown, altered in colour by Lord Coleridge, $\mathrm{I} 62$

Triskele in the coat-of-arms of the Isle of Man, 86

_- - _ - Sicily, 86

Trousers, bell-bottom, 259

- evolution of, 55

- method of buttoning bishops', I87

- not worn by Romans, 56

- of labourers, method of buttoning, 187

- sailors, method of buttoning, I 87

- shown on Trajan's column, 56

- worn by barbarians, 56,57

- - lady gardeners at Kew, 267

- - Normans, 57

- - Saxons, 57, 58

- - women in Siam, 57 i see Plate V, facing page 57

- - - Persia, 57

- - in riding dress by ladies, 268

Trumpeters, State, uniform of, I79

Trumpington, Sir Richard de, brass of, showing chain mail, I73, 174

Trunk hose of clown, 200

- - of Knightly Orders, I $7 \mathrm{r}$

Tudor dresses, shown by playing cards, 172

- flat cap, I6o

Tunic, 13, 13, 139

- developed from the shawl, I3, 14

Tunic, Egyptian, I3

- Greek, I3, 13

- of monks, I49

- sleeved, I4

- survival of the Anglo-Saxon, $2{ }_{5}$

Tunica alba, I4I

Tunicle, 145,165
Tunics, black, of farriers of Life Guards, I 79

- of Anglo-Saxons compared with a shirt, 2I 5

- Lacedæmonian girls slit down the side, 256

Turban like the dome of a mosque, 36,37

Turquoises always fashionable, 90

Twenty-Ninth Foot, sergeants of, wear sashes over their left shoulders I84

Twain, Mark, 254

Tylor, Dr., on finger-rings, 83

- - painting in war time by civilized races, 202

- - the tendency to give up savage ornaments, $8 \mathrm{I}$

ULSTER, I08

Underclothes, lack of, 269

Uniforms, naval, I86

- of Hussars, 202

- - Navy, date from $\times 767$, I 86

- - sergeant worn by extra drummer, 180

- military, regular adoption of, $\mathrm{I}_{74}$

— - solicitor of Guards, I82

- service, protectively coloured, I75

- gay, only used in times of peace, I75

Union Jack on King's colours of Coldstream Guards, 182

Ushabti, models of servants put into Egyptian graves, 199

VeIL of a bride, I29

- - novice, 150

- nun, I50, 150

- - postulants, I50

Vergers, costume of, I6 3

Vermiform appendix, 2

Vestments, adoption of, by English High Church clergy, I 43

- baptismal, I20

- ecclesiastical, I37

- of High Church clergy, coloured, adopted by, 227

Vestments, ornaments of, gradually acquired, I39

- prescribed by the first Prayer Book of Edward VI, I47

- prohibited by second Prayer Book of Edward VI, I48

- of Presbyterian clergy, pro- 
Vestments worn at the celebration of the Eucharist, 144

Vestige of a row of buttons, stripe on trousers, 59,59

- - the coif from wig of a sergeantat-law, I62, 162

Vestiges, buttons on postilions, 27

- of the fillet, 37,39

- in the animal kingdom, 3

Vickery, Dr. Alice, on children's dress, I2I

Villiers-en-Couche, battle of, I8I

Voice of Punch, I95

Vowesses, I35

WAIsT, wasp-like, 240

Waistbands, trade in discarded Paris, 259

Waistbelts, Professors Roy and Adami, on the beneficial use of, 246

Waistcoat, 108

Waiter, I04

Waiters, evening dress of, Io4, I ro

Wales', Prince of, feathers a hereditary badge, 66

Wand of harlequin, 2 II

Warp, I3

- of hand loom, 86

Waterloo, battle of, I8I

Watermen, badges of, 66

Wearing of talismans by ancient Egyptians, 89

Weddings, superstitions at, I30

Weights, leaden, used by women to flatten their chests, 250

Weeds, old meaning of the word, I35

- widow's, I35

Weft of hand loom, 86

Wells, Blue schools at, I24

Welsh Fusiliers, flash of, 97, 98, I79

Westminster, coats at, I24

Whips, fashions in, 226

Whiskers, effect of bushy, 95

White as mourning, I34

- clothes of butterman, 237

- - man cook, 237

Widows, costume of, I 47

Wig of coachman, I03, 105

Wig of judge, r6I, 162

- - - depression in, I6I

- doctor in the Punch and Judy show 197

Wig-bag of Court dress, I69, 170

- remnant of, 97

- on liveries of servants, 98, 106

- of Lord Mayor's coachman, 98, I03, 106
Wigs, barristers', 96

- coachmen's, 96

- imitating curly hair, 95

- footmen's, 96

- judges, 96

- legal, I6I

- of East End Jewesses, 93

- Egyptians, 93

- Parliamentary officials, 96

—- Serjeants-at-law, I6I

- value of, I70

Wilhelmstahl, battle of, I8I

William Rufus, hanging sleeves of the time of, 156

Wimple, I29, I50

- of Norman ladies, I 50

- of the time of the Plantagenets, I 50

Winchester scholars, bands of, I24

Wolfe, General, black worm worn as mourning for, I 79

Women, Arab, 89

- - ideas of modesty, I 54

- barge, apron of, I09; see Plate VIII, facing page IIO

- colour preferences of, 229

- covering their faces, IO, I54

- dress of; varies little, I2

- in church without hats, Io, I54

- - many places wear trousers, 266

- married, not to wear caps, $26 \mathrm{I}$

- milk, Io9

- - yokes of, 80

- Padaung, metal collars of, 83: see Plate VI, facing page 83

- rational dress for, 269

- riding astride, 268

- the first to wear clothes, 9

- Welsh and Italian, age rapidly, 244

Wood, Mr. Walter, on white jackets for soldiers, I8o

Woodville, Mr. Caton, on aiguillettes, I77

Worm, black, of East Yorkshire regiment, I79

_ - mourning for Sir John Moore, I 79

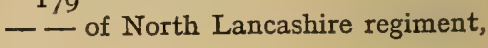
I79

Worm, black, of Somersetshire Light Infantry, I79

- - worn as mourning for General Wolfe, I 79

- sldw, third eye in, 2

Wristbands, I8

YELLOW as mourning, I35

- a favourite colour of gipsies, 228 


\section{INDEX}

Yellow mourning colour in Oriental countries, 228

- worn by mediæval Jews, 228

Yeomen of the Guard, badges of, 167 167

_ - - dress of, 167

- - - duties of, 168

- - - officers, dress of, $\mathrm{I} 68$
Yeomen of the Guard, officers of, wear the uniform used in the Peninsular War, 168 Yoke, $79, \frac{-}{80}$ original uniform of 168

- of milk woman, 80

Yoxall, Mr., on wearing of yellow by Jews, 228

Jarrold of Sons, Ltd., The Empire Press, Norwich. 




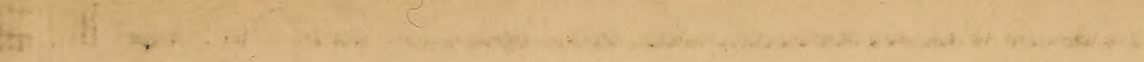


